University of Nebraska - Lincoln

DigitalCommons@University of Nebraska - Lincoln

1993

Systematics, Biostratigraphy, and Dental Evolution of the

Palaeothentidae, Later Oligocene to Early-Middle Miocene

(Deseadan-Santacrucian) Caenolestoid Marsupials of South

\title{
America
}

Thomas M. Bown

U.S. Geological Survey

John G. Fleagle

State University of New York

Follow this and additional works at: https://digitalcommons.unl.edu/usgsstaffpub

Part of the Earth Sciences Commons

Bown, Thomas M. and Fleagle, John G., "Systematics, Biostratigraphy, and Dental Evolution of the Palaeothentidae, Later Oligocene to Early-Middle Miocene (Deseadan-Santacrucian) Caenolestoid Marsupials of South America" (1993). USGS Staff -- Published Research. 209.

https://digitalcommons.unl.edu/usgsstaffpub/209

This Article is brought to you for free and open access by the US Geological Survey at DigitalCommons@University of Nebraska - Lincoln. It has been accepted for inclusion in USGS Staff -- Published Research by an authorized administrator of DigitalCommons@University of Nebraska - Lincoln. 
The Paleontological Society

MEMOIR 29

\section{SYSTEMATICS, BIOSTRATIGRAPHY, AND DENTAL EVOLUTION OF THE PALAEOTHENTIDAE, LATER OLIGOCENE TO EARLY-MIDDLE MIOCENE (DESEADAN-SANTACRUCIAN) CAENOLESTOID MARSUPIALS OF SOUTH AMERICA}

\section{Thomas M. Bown and John G. Fleagle}

U.S. Geological Survey, Box 25046, Mail Stop 919, Denver Federal Center, Denver, Colorado 80225 and Department of Anatomical Sciences, State University of New York, Stony Brook, New York 11794

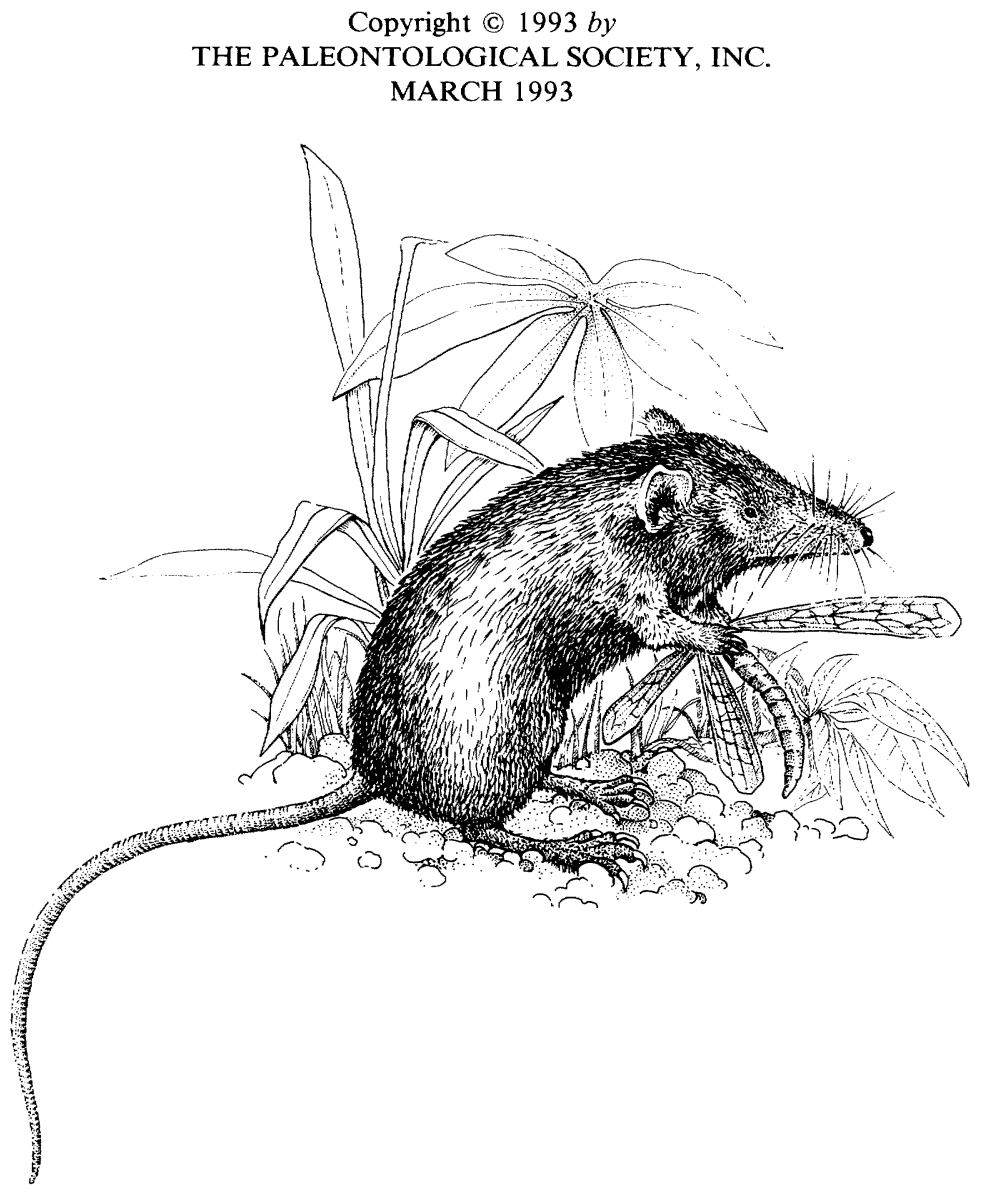

Reconstruction of the small faunivorous Santacrucian palaeothentine Palaeothentes minutus, by Marj Leggitt. 


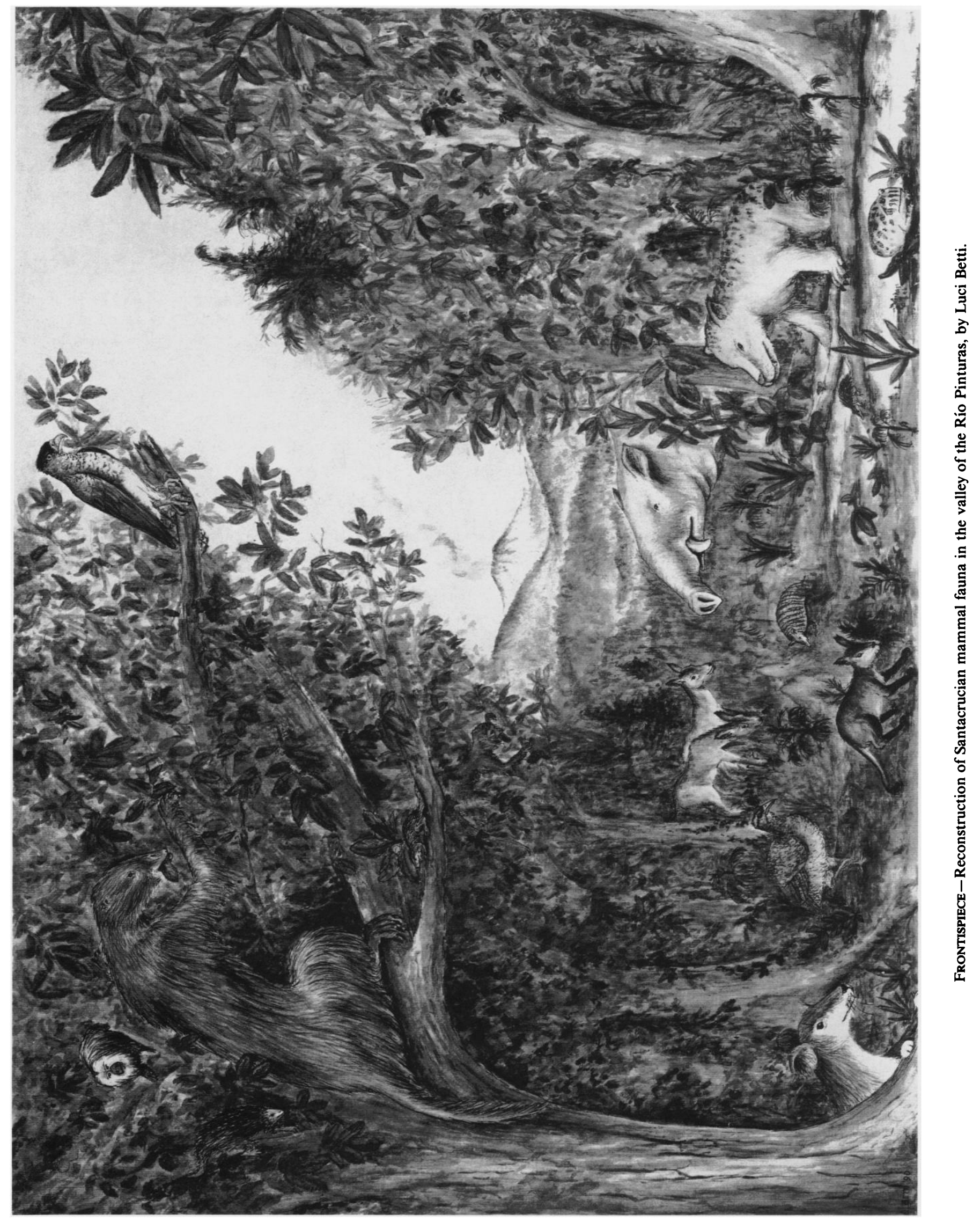




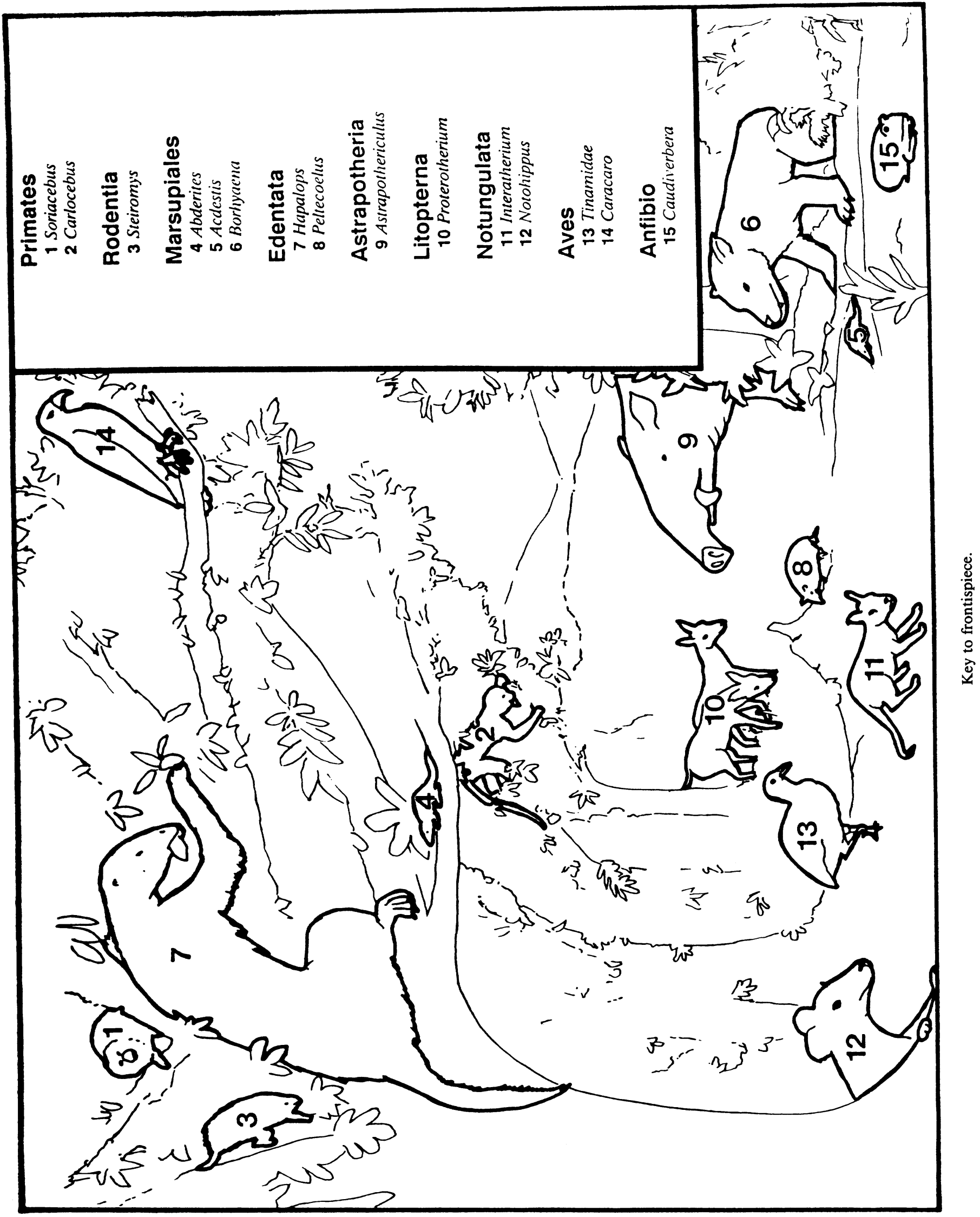




\section{Contents}

Abstract

RESUMEN

INTRODUCTION

COMPOSITION AND History OF PALAeOthentidae

New Collections $\ldots \ldots \ldots \ldots \ldots \ldots \ldots \ldots \ldots \ldots \ldots \ldots \ldots \ldots$

AbBreviations and Mensuration $\ldots \ldots \ldots \ldots \ldots \ldots \ldots$

LOCALITIES AND CORRELATION

SACANANA (Colhuéhuapian)

LA CANTERA (Colhuéhuapian)

Estancia la Cañada, Gobernador Gregores, and Lago

CARDIEL (Santacrucian)

Monte Observación (Santacrucian) $\ldots \ldots \ldots \ldots \ldots \ldots \ldots$

Río Chalia (Santacrucian) $\ldots \ldots \ldots \ldots \ldots \ldots \ldots \ldots \ldots \ldots$

Monte León (Santacrucian) $\ldots \ldots \ldots \ldots \ldots \ldots \ldots \ldots \ldots, 12$

Correlation of the Pinturas and Santa Cruz

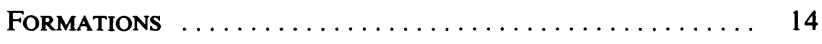

Temporal Reconstruction $\ldots \ldots \ldots \ldots \ldots \ldots \ldots \ldots \ldots, 16$

Systematic Paleontology $\ldots \ldots \ldots \ldots \ldots \ldots \ldots \ldots \ldots .17$

FAMILY Palaeothentidae (Sinclair, 1906) Osgood, $1921 \quad \ldots . \quad 17$

SubfaMily Acdestinae n. subfam. .............. 17

Genus Acdestoides n. gen. .................. 17

Acdestoides praecursor (Loomis, 1914) $\ldots \ldots \ldots \ldots .17$

GeNus Acdestodon n. gen. ................... 18

Acdestodon bonapartei $\mathrm{n} . \mathrm{sp} . \quad \ldots \ldots \ldots \ldots \ldots \ldots \ldots, 18$

Genus Trelewthentes n. gen. ................ 19

Trelewthentes rothi $\mathrm{n} . \mathbf{s p} . \quad \ldots \ldots \ldots \ldots \ldots \ldots \ldots, 21$

Genus Acdestis Ameghino, $1887 \quad \ldots \ldots \ldots \ldots \ldots \ldots . \ldots 21$

Acdestis oweni Ameghino, $1887 \quad \ldots \ldots \ldots \ldots \ldots \ldots . \ldots 22$

Acdestis lemairei n. sp. .................... 23

Subfamily Palaeothentinae Sinclair, $1906 \quad \ldots \ldots \ldots \ldots 29$

Genus Carlothentes n. gen. ................. 29

Carlothentes chubutensis (Ameghino, 1897) ....... 29

Genus Palaeothentes Ameghino, $1887 \quad \ldots \ldots \ldots \ldots \ldots . \ldots 1$

Palaeothentes boliviensis Patterson and Marshall,

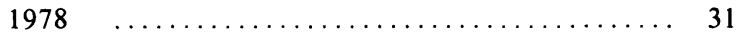

Palaeothentes primus (Ameghino, 1902) ......... 31

Palaeothentes marshalli n. sp. ................ 32

Palaeothentes migueli n. sp. ................. 32

Palaeothentes minutus Ameghino, 1887 .......... 35

Palaeothentes pascuali n. sp. ................ 38

Palaeothentes intermedius Ameghino, 1887 ...... 39

Palaeothentes lemoinei Ameghino, 1887 ......... 41

Palaeothentes aratae Ameghino, 1887 ......... 43

Genus Propalaeothentes n. gen. ............... 45

Propalaeothentes lepidus (Ameghino, 1891) ....... 45

Propalaeothentes hatcheri $\mathrm{n}$. sp. ............ 47

Genus Pilchenia Ameghino, $1903 \quad \ldots \ldots \ldots \ldots \ldots \ldots . . .47$

Pilchenia lucina Ameghino, $1903 \quad \ldots . \ldots . \ldots . \ldots .47$

FAMILy Palaeothentidae, incertae sedis $\ldots \ldots \ldots \ldots \ldots \ldots .49$

Genus Hondathentes Dumont and Bown, in press ...... 49

Hondathentes cazador Dumont and Bown, in press .... 52

Evolution of the Palaeothentidae $\ldots \ldots \ldots \ldots \ldots \ldots \ldots \quad 52$

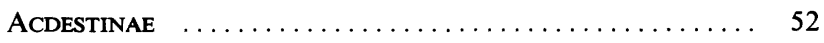

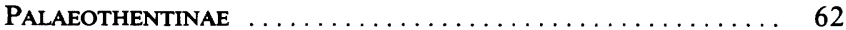

Origin of Palaeothentidae $\ldots \ldots \ldots \ldots \ldots \ldots \ldots \ldots \ldots, 71$

SUMMARY AND CONCLUSIONS $\ldots \ldots \ldots \ldots \ldots \ldots \ldots \ldots . \ldots \ldots$

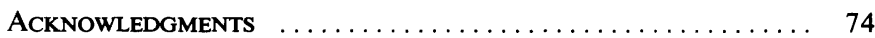

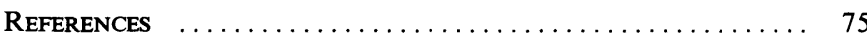

\section{ILLUSTRATIONS}

FIGURES

FRONTISPIECE-Reconstruction of Santacrucian mammal fauna ii

Key to frontispiece $\ldots \ldots \ldots \ldots \ldots \ldots \ldots \ldots \ldots \ldots \ldots$ iii

1-Distribution of palaeothentid localities of South

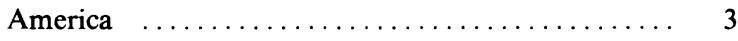

2-Distribution of Argentine Palaeothentidae ...... 5

3-Exposures of Sarmiento Formation at localities of Sacanana and La Cantera $\ldots \ldots \ldots \ldots \ldots \ldots . \ldots 6$

4-Exposure of Pinturas Formation, Estancia El Carmen .............................

5-Exposures of Pinturas? Formation at Estancia La Cañada, Gobernador Gregores, and Lago Cardiel ... 11

6-Exposures of Santa Cruz Formation at Monte Observación and along the Río Chalia $\ldots \ldots \ldots \ldots, 12$

7-Stratigraphic positions of fossil vertebrate localities, Monte Observación $\ldots \ldots \ldots \ldots \ldots \ldots \ldots \ldots \ldots$

8-Exposures of Santa Cruz Formation, Monte León .. 14

9-Correlation of fossil vertebrate localities between Monte León and Monte Observación _........ 15

10-Acdestodon bonapartei $\mathrm{n}$. gen. and sp. ......... 18

11 -Trigonid structure in Palaeothentidae .......... 19

12-Trelewthentes rothi $\mathrm{n}$. gen. and sp. .......... 21

13-Acdestis oweni Ameghino ................ 22

14-Acdestis lemairei $\mathbf{n}$. sp. $\ldots \ldots \ldots \ldots \ldots \ldots \ldots \ldots .26$

15-Acdestodon bonapartei $\mathrm{n}$. gen. and sp., Trelewthentes rothi $\mathrm{n}$. gen. and sp., Acdestis oweni Ameghino,

Acdestis lemairei n. sp. .................. 27

16-Palaeothentes marshalli $\mathrm{n} . \mathrm{sp} . \quad \ldots \ldots \ldots \ldots \ldots \ldots, 32$

$17-$ Palaeothentes migueli $\mathrm{n}$. sp. ................ 34

18-Palaeothentes minutus Ameghino ............ 35

19-Palaeothentes pascuali $\mathrm{n}$. sp. .............. 39

20-Palaeothentes intermedius Ameghino ......... 39

21-Palaeothentes lemoinei Ameghino ............ 41

22-Palaeothentes aratae Ameghino ............. 43

23-Propalaeothentes lepidus (Ameghino) ........... 45

24-Palaeothentes primus Ameghino; P. marshalli n. sp., $P$. minutus Ameghino, P. intermedius Ameghino ... 46

25-Palaeothentes migueli n. sp., P. lemoinei Ameghino, $P$. aratae Ameghino, Propalaeothentes lepidus (Ameghino), P. hatcheri n. sp. ............. 48

26-Principal clades of Palaeothentidae $\ldots \ldots \ldots \ldots \ldots \quad 53$

27-Phylogeny of Acdestinae $\ldots \ldots \ldots \ldots \ldots \ldots \ldots .54$

28-Distribution of $\mathrm{ml}$ area in Deseadan-Santacrucian Palaeothentidae $\ldots \ldots \ldots \ldots \ldots \ldots \ldots \ldots \ldots \ldots, 56$

29-Distribution of $\mathrm{m} 2$ area in Deseadan-Santacrucian Palaeothentidae ..................... 57

30-Distribution of $\mathrm{m} 3$ area in Deseadan-Santacrucian Palaeothentidae ....................... 58

$31-$ Ratio of $\mathrm{m} 3$ area to $\mathrm{m} 2$ area in DeseadanSantacrucian Palaeothentidae $\ldots . . . \ldots \ldots \ldots . . . .$. 
32-Observed ranges and means of $\mathrm{m} 3$ area/m2 area in Deseadan-Santacrucian Palaeothentidae ......... 60

33-Overlap of $\mathrm{ml}$ area in Santacrucian Palaeothentidae 61

34-Overlap of $\mathrm{m} 2$ area in Santacrucian Palaeothentidae 61

35-Trigonid structure of $\mathrm{ml}$ and ramal depth in Acdestinae $\ldots \ldots \ldots \ldots \ldots \ldots \ldots \ldots \ldots \ldots, 62$

36-Time-stratigraphic size distribution of $\mathrm{ml}$ area in Acdestis oweni Ameghino ................ 63

37-Time-stratigraphic size distribution of $\mathrm{m} 2$ area in Acdestis oweni Ameghino ................ 64

38-Time-stratigraphic size distribution of $\mathrm{m} 3$ area in Acdestis oweni Ameghino .................. 65

39-Tuff unit 8 at Monte Observación $\ldots \ldots \ldots \ldots \ldots 66$

40-Ratio of $\mathrm{m} 3$ area to $\mathrm{m} 2$ area in Acdestis oweni Ameghino ......................... 66

41-Time-stratigraphic distribution of $\mathrm{m} 1$ trigonid structure in Acdestis ..................... 67

42-Phylogeny of Palaeothentinae $\ldots \ldots \ldots \ldots \ldots \ldots 68$

43-Time-stratigraphic distribution of $\mathrm{ml}$ area in Palaeothentes minutus Ameghino and $P$. pascuali $\mathrm{n}$. sp. ............................... 69

44-Time-stratigraphic distribution of $\mathrm{m} 2$ area in Palaeothentes minutus Ameghino and $P$. pascuali $\mathrm{n}$.

sp. ............................... 70

45-Palaeothentes aratae Ameghino $\ldots \ldots \ldots \ldots \ldots .71$

46-Phylogenies of $\mathrm{ml}$ morphology in Palaeothentidae 72

\section{TABLES}

1-Taxa of Palaeothentidae

2-Correlation of fossil vertebrate localities, Pinturas and Santa Cruz Formations
3-Radiometric dates for Monte León, Pinturas, and Santa Cruz Formations $\ldots \ldots \ldots \ldots \ldots \ldots \ldots$

4-Specimen data for Trelewthentes rothi $\mathrm{n}$. gen. and

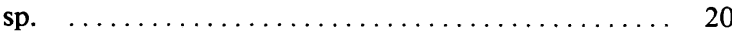

5-Specimen data for new specimens of Acdestis oweni Ameghino ........................ 24

6-Specimen data for Acdestis lemairei n. sp. ....... 28

7-Specimen data for Acdestoides praecursor (Loomis), Acdestodon bonapartei n. gen. and sp., Carlothentes chubutensis (Ameghino), Palaeothentes boliviensis Patterson and Marshall, $P$. primus Ameghino, $P$. pascuali n. sp., Pilchenia lucina Ameghino, Propalaeothentes lepidus (Ameghino), P. hatcheri $\mathrm{n}$. sp., and Hondathentes cazador Dumont and Bown

8-Specimen data for Palaeothentes marshalli n. sp. . . 33

9-Specimen data for Palaeothentes migueli $\mathrm{n}$. sp. .... 34

10-Specimen data for new specimens of Palaeothentes minutus Ameghino ...................... 36

11-Specimen data for new specimens of Palaeothentes intermedius Ameghino ................... 40

12-Specimen data for new specimens of Palaeothentes lemoinei Ameghino .......................

13-Specimen data for new specimens of Palaeothentes aratae Ameghino ..................... 44

14-Derived dental characters in Palaeothentidae ..... 49

15-Parallel and convergent dental characters in the Palaeothentidae ..................... 50

16-Time-stratigraphic representation of $\mathrm{ml}$ trigonid structure in Acdestis oweni Ameghino 


\title{
SYSTEMATICS, BIOSTRATIGRAPHY, AND DENTAL EVOLUTION OF THE PALAEOTHENTIDAE, LATER OLIGOCENE TO EARLY-MIDDLE MIOCENE (DESEADAN-SANTACRUCIAN) CAENOLESTOID MARSUPIALS OF SOUTH AMERICA
}

\author{
THOMAS M. BOWN AND JOHN G. FLEAGLE \\ U.S. Geological Survey, Box 25046, Mail Stop 919, \\ Denver Federal Center, Denver, Colorado 80225 and \\ Department of Anatomical Sciences, State University of New York,
} Stony Brook 11794

\begin{abstract}
The family Palaeothentidae contains some of the dentally more specialized of the small-bodied marsupials of South America and was a clade almost equivalent with the Abderitidae in having been the most abundant caenolestoids. They were unquestionably the most diverse, containing two subfamilies, nine genera, and 19 species, with a distribution ranging from Colombia to Tierra del Fuego. The best and most continuous record of the Palaeothentidae is from Patagonian Argentina where eight genera and 17 species are recognized. There, the Palaeothentidae ranged in age from the Deseadan (later Oligocene) through the late Santacrucian (middle Miocene-the Santacrucian record lasting from about $19.4 \mathrm{~m}$.y. to considerably less than $16.05 \mathrm{~m} . \mathrm{y}$. before the present). The family appears to have survived longer in Colombia. The palaeothentine Palaeothentes boliviensis (Bolivia) and the incertae sedis genus and species Hondathentes cazador (Colombia) are the only taxa restricted to an extra-Argentine distribution.

Two palaeothentid subfamilies are recognized. The subfamily Acdestinae is new and is erected to accommodate four genera and five species of herbivorous to frugivorous palaeothentids known from the Deseadan through the middle-late Santacrucian. Three of those genera are new (Acdestoides, Acdestodon, and Trelewthentes), as are three acdestine species placed in the genera Acdestodon, Trelewthentes, and Acdestis. The largely faunivorous Palaeothentinae includes four genera and 13 species; the genera Propalaeothentes and Carlothentes are new and new species are described for the genera Propalaeothentes (2) and Palaeothentes (3). Carlothentes is named for Ameghino's Deseadan species Epanorthus chubutensis, and Ameghino's genus Pilchenia is resurrected to accommodate Deseadan P. lucina. New species include: Acdestodon bonapartei, Trelewthentes rothi, Acdestis lemairei, Palaeothentes marshalli, $P$. migueli, P. pascuali, and Propalaeothentes hatcheri.

The Palaeothentinae contains more generalized palaeothentid species than does the Acdestinae, but also includes some very specialized forms. The most generalized known palaeothentid is the Colombian Hondathentes cazador. Both the Acdestinae and Palaeothentinae have large- and small-bodied species; Palaeothentes aratae was the largest palaeothentid (about $550 \mathrm{~g}$ ), and $P$. pascuali $\mathrm{n}$. sp. the smallest (about $50 \mathrm{~g}$ ). The oldest known members of both subfamilies consist of five of the six largest palaeothentids.

The evolutionary history of the Palaeothentidae is complicated by thick sequences containing no fossils, several lacunae in sequences that yield fossils, and a continent-wide distribution of localities. By far the densest and most continuous record of the family exists in the coastal Santa Cruz Formation of Patagonian Argentina. Three major clades exist within the Palaeothentidae: 1) the incertae sedis species Hondathentes cazador; 2) the Acdestinae; and 3) the Palaeothentinae (including the new genus Propalaeothentes). The evolution of dental characters in these clades is documented with the aid of 719 new specimens (about $80 \%$ of the hypodigm of the family), most of which (about $90 \%$ of the new specimens) have precise stratigraphic data.

Biostratigraphic study of the new samples was assisted by a new technique of temporal analysis of paleosols and by radiometric age determinations, the latter indicating that the upper part of the Pinturas Formation (16.6 Ma) is older than the lower part of the Santa Cruz Formation (16.4 Ma) and that the top of the marine Monte León Formation (Grupo Patagonica) is older than either (19.4 Ma).

Fifty-two gnathic and dental characters were used to identify the taxonomy and to reconstruct the phylogeny of the Palaeothentidae. Analysis of sequencing of appearances of derived characters documents rampant convergences at all taxonomic levels and considerable phenotypic plasticity (variable percent representation of different mutable character morphs) in the organization of the palaeothentid dentition. Certain highly generalized character states survive for the duration of the family in some lineages, whereas others are phenotypically lost for a time and then reappear as a minor percentage of character variability. In general, replacement faunas of palaeothentids were morphologically more generalized than their antecedent forms. The high rate of character mutability and the survival and reappearance of generalized dental characters in the Palaeothentidae were probably related to massive events of pyroclastic deposition that periodically caused at least local extinctions of small mammal populations throughout the duration of the Patagonian middle Tertiary. Dental character regression indicates that palaeothentids arose prior to the Deseadan from a relatively large-bodied marsupial having generalized tribosphenic molars with more or less bunodont cusps; probably an unknown member of the Didelphidae.
\end{abstract}

Resumen-La familia Palaeothentidae contiene algunos de los marsupiales de pequeño tamaño corporal de Sud América más especializados dentalmente y es un clado casi equivalente a Abderitidae en haber sido los más abundantes cenolestoideos. Eran indudablemente los más diversos, conteniendo dos subfamilias, nueve géneros, y 19 especies, con una distribución que se extendia desde Colombia hasta Tierra del Fuego. El mejor y más continuo registro de Palaeothentidae es de Patagonia, Argentina, donde se reconocen ocho generos y 17 especies. Alli, el registro de Palaeothentidae se extiende en edad desde el Deseadense (Oligoceno tardio) hasta el Santacrucense tardio (Mioceno medio-el registro Santacrucense dura desde aproximadamente 19.4 ma hasta considerablemente menos de $16.05 \mathrm{ma}$ antes del presente). La familia parece haber sobrevivido más tiempo en Colombia. Los palaeotentinos Palaeothentes boliviensis (Bolivia) y el género y especie incertae sedis Hondathentes cazador (Colombia) son los únicos taxones restringidos a una distribucion fuera de Argentina.

La subfamilia Acdestinae es nueva y es erigida para ubicar cuatro géneros y cinco especies de Palaeothentidae conocidos desde el Deseadense hasta el Santacrucense medio-tardio. Tres de esos géneros son nuevos (Acdestoides, Acdestodon, y Trelewthentes), asi también como tres especies de acdestinos de los generos Acdestodon, Trelewthentes, y Acdestis. Los muy carnivoros paleotentinos 
incluyen cuatro géneros y 13 especies; los géneros Propalaeothentes y Carlothentes son nuevos y se describen nuevas especies para el género Propalaeothentes (2) y Palaeothentes (3). Carlothentes es el nombre que se le da a la especie deseadense Epanorthus chubutensis de Ameghino, y el género Pilchenia es revalidado para ubicar a P. lucina. Nuevas especies se incluyen: Acdestodon bonapartei, Trelewthentes rothi, Acdestis lemairei, Palaeothentes marshalli, P. migueli, P. pascuali, y Propalaeothentes hatcheri.

Palaeothentinae contiene especies de paleoténtidos más generalizadas que Acdestinae, pero también incluye formas muy especializadas. El paleoténtido más generalizado conocido es Hondathentes cazador de Colombia. Ambos Acdestinae y Palaeothentinae tienen especies de tamaños corporales grande y pequeño; Palaeothentes aratae era el paleoténtido más grande (cerca de $550 \mathrm{~g}$ ), y $P$. pascuali $\mathrm{n}$. sp. el más pequeño (cerca de $50 \mathrm{~g}$ ). Los miembros más antiguos conocidos de ambas familias consisten en cinco de los seis más grandes paleoténtidos.

La historia evolutiva de Palaeothentidae es complicada por gruesas secuencias que no contienen fósiles, varios lacunos em secuencias que sí los continien, y una distribución de amplitud continental de localidades. Por lejos el registro más denso y más continuo de la familia se encuentra en la costera Formación Santa Cruz. Existen tres clados mayores dentro de Palaeothentidae: 1) la especie incertae sedis Hondathentes cazador; 2) Acdestinae; y 3) Palaeothentinae (incluyendo el nuevo género Propalaeothentes). La evolución de los caracteres dentales en estos clados está documentada con la contribución de 719 nuevos especimenes (casi $80 \%$ del hipodigma de la familia), la mayoria de los cuales (casi $90 \%$ de los nuevos especímens) tienen datos estratigráficos precisos. El estudio bioestratigráfico de las muestras nuevas fue hecho mediante una nueva técnica de análisis temporal de paleosuelos y por determinaciones radiométricas de edad; las últimas indican que la parte superior de la Formación Pinturas (16,6 ma) es más antigua que la parte inferior de la Formación Santa Cruz (16,4 ma), y que el techo de la marina Formación Monte León (Grupo Patagónico) es más antigua que ambas (19,4 ma).

Se usaron cincuenta y dos caracteres gnáticos y dentales para identificar la taxonomía y reconstruir la filogenia de Palaeothentidae. El análisis de la secuencia de aparición de caracteres derivados documenta convergencias anbundantes en todos los niveles taxonómicos y considerable plasticidad fenotípica (representación porcentual variable de diferentes morfologías de caracteres cambiantes) en la organización de la dentición de Palaeothentidae. Estados de carácter altamente generalizados sobreviven durante toda la existencia de la familia en algunos linajes, mientras que otros se pierden fenotípicamente durante un tiempo y luego reaparecen como un porcentaje menor de variabilidad. En general, las faunas de reemplazo de paleoténtidos eran morfológicamente más generalizadas que sus formas antecesoras. La alta tasa de mutabilidad de caracteres y la alta supervivencia y reaparición de caracteres dentales generalizados en Palaeothentidae estuvo probablemente realacionada con eventos masivos de depositación piroclástica que periodicamente causaron al menos extinciones locales de poblaciones pequeñas de mamíferos durante todo el Terciario medio patagoniano. La regresión de caracteres dentales indica que los paleoténtidos aparecieron antes del Deseadense y su antecesor debio ser un marsupial de tamaño corporal relativamente grande con molares tribosfénicos con cúspides más o menos bunodontes; probablemente un miembro desconocido de Didelphidae.

\section{INTRODUCTION}

$C^{o}$ Tomposition aND history of Palaeothentidae. - The Palaeothentidae are an important family of extinct caenolestoid marsupials that occupied parts of South America (Figure 1) from at least later Oligocene through later Miocene time. At least four species are known from rocks of Deseadan age: one species from Bolivia (La Salla) and three from Argentina (Cabeza Blanca). The latest known survivor of the Palaeothentidae was found recently in the middle-upper Miocene Honda Formation of Colombia (Dumont and Bown, in press). All other known palaeothentids had an exclusively Argentine or Chilean Patagonian distribution (Figures 1,2), where they are known from rocks of Deseadan (Argentina) through Santacrucian (Argentina and Chile) age.

Palaeothentids are known principally from dental remains and two skulls, although undescribed postcranial bones exist for some species. Dentally, palaeothentids differ from the more generalized Caenolestidae (which has living representatives) in having a more reduced antemolar dentition (excepting P3), in the reduction and loss of paraconids on the posterior molars, in the great anterior expansion of the $\mathrm{m} 1$ paracristid and consequent increase in first molar size, and in the confluence (or near confluence) of the $\mathrm{m} 1$ cristid obliqua with the metaconid, far to the lingual margin of the tooth. The more specialized Abderitidae (also extinct caenolestoids) possess simpler, more rectangular $\mathrm{m} 2-4$, and (Abderitinae) a hypertrophied, shearing $\mathrm{m} 1$ that is reminiscent of $\mathrm{p} 4$ in Paleogene North American carpolestid plesiadapiformes and some families of multituberculates. The parabderitine abderitids have conjoined, hypertrophied $\mathrm{p} 3$ and $\mathrm{m} 1$, resulting in a bladelike structure similar to $\mathrm{m} 1$ in Abderitinae.

The closest living palaeothentid relatives are three genera and seven species of Caenolestidae (rat opossums). Living caenolestids are terrestrial, nocturnal to crepuscular, mixed insectivorous-herbivorous feeders that enjoy cold, densely vegetated areas ranging from altitudes of 0 to $4,250 \mathrm{~m}$ (e.g., Walker et al., 1975; Kirsch and Calaby, 1977; Marshall, 1980; Honacki et al., 1982). Paleoenvironmental studies (Bown and Larriestra, 1990; Bown and Laza, 1990) indicate that at least some of the extinct Palaeothentidae preferred forested to more open subtropical habitats on the Atlantic coast, in the central Llano Patagónica and in the Andean Precordillera (Frontispiece 2).

Between 1887 and 1903 Florentino Ameghino described 16 genera and 37 species of palaeothentids. Simpson (1945) reduced the number of genera to five, and Marshall (1980) recognized only 10 valid species in but two of Ameghino's firstnamed genera, Palaeothentes and Acdestis (Ameghino, 1887). The Palaeothentidae have received little attention and have been reviewed but twice, first by Ameghino in 1898, and a second, excellent, and comprehensive revision by Marshall (1980), which included a full taxonomic history of the family (as subfamily Palaeothentinae) and its members. It has only been due to Marshall's exceptionally thorough revision that the present study was made possible. In the latter work, Marshall provided a complete listing of generic and specific synonyms of Palaeothentidae, and it is therefore deemed superfluous to record any but the most important and most recent additions herein.

In 1990, Marshall described additional specimens of three species of palaeothentids from the type area of the Friasian landmammal age in the Alto Río Cisnes area of Chile, elevating his (1980) construct of the Palaeothentinae to family rank. We endorse and adopt that usage here and recognize two subfamilies of Palaeothentidae, Acdestinae and Palaeothentinae, both of which are rediagnosed. As currently conceived, the Palaeothentidae are classified in the marsupial order Paucituberculata (Ride, 1964), superfamily Caenolestoidea, with two other caenolestoid families, the Caenolestidae and Abderitidae (see also Kirsch, 1968, 1977; Simpson, 1970, 1971; Clemens and Marshall, 1976; and Marshall, 1981). 


\section{Caribbean Sea}

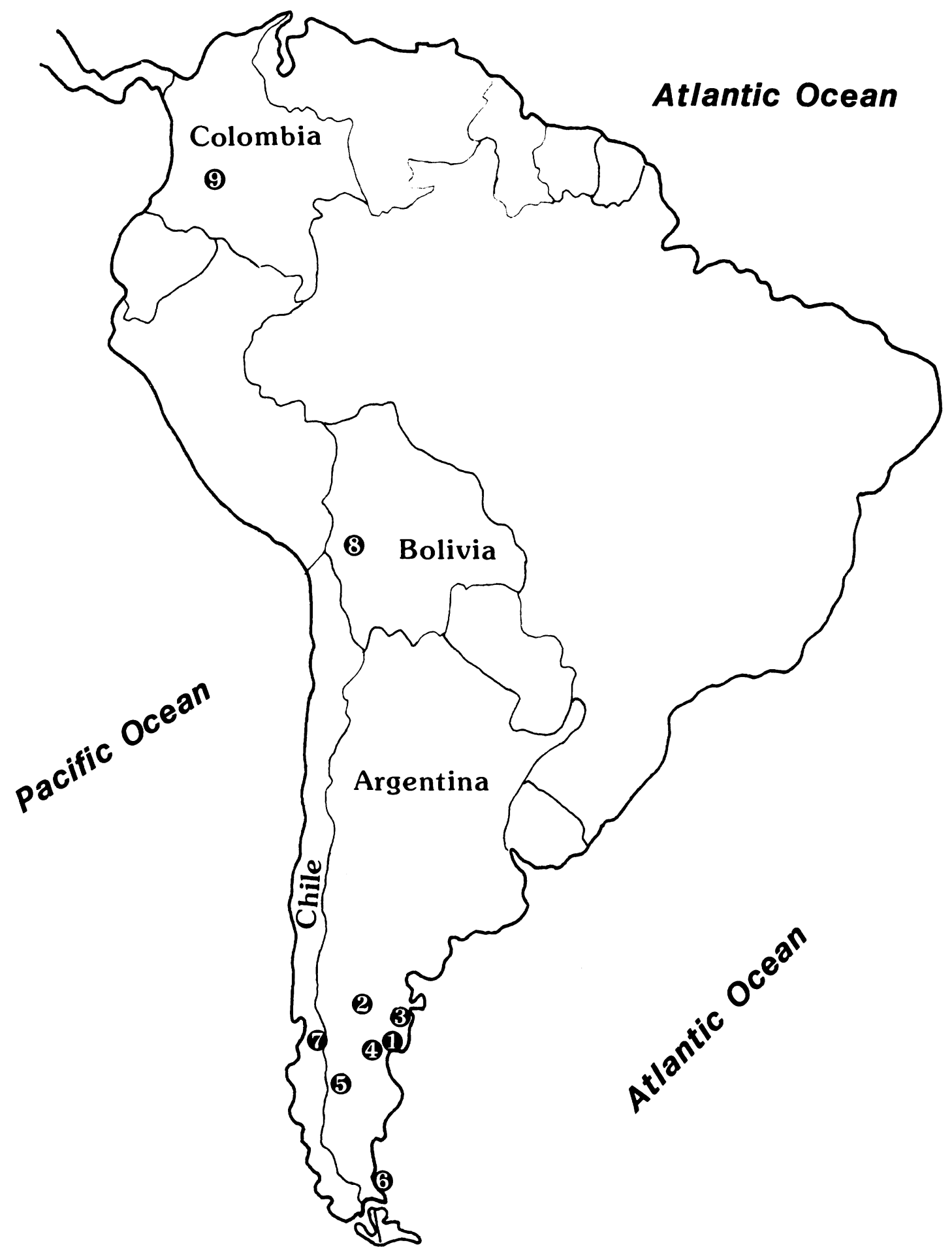

FIGURE 1-Geographic distribution of principal areas yielding fossil Palaeothentidae in South America. 1, Cabeza Blanca (Deseadan, Arg.); 2 , Sacanana (Colhuéhuapian, Arg.); 3, La Cantera (Colhuéhuapian, Arg.); 4, Gran Barranca (Deseadan? and Colhuéhuapian, Arg.); 5 , Río Pinturas (Santacrucian, Arg.); 6, Coastal Santa Cruz Formation, including Monte Observación and Monte León (Santacrucian, Arg.); 7, Alto Río Cisnes (Santacrucian, Chile); 8, Salla-Yuribay Basin (Deseadan, Bolivia); 9, Honda Formation (late Santacrucian or younger, Colombia). 
TABLE 1-Genera and species of Palaeothentidae recognized in this study, contrasted with those of the Palaeothentinae of Marshall (1980).

\begin{tabular}{ll}
\hline \multicolumn{1}{c}{ This study } & \multicolumn{1}{c}{ Marshall, 1980 } \\
\hline \hline Acdestoides praecursor, n. gen. (Loomis, 1914) & Acdestis praecursor (Loomis, 1914) \\
Acdestodon bonapartei, n. gen. and sp. & not known \\
Trelewthentes rothi, n. gen. and sp. & not known \\
Acdestis oweni Ameghino, 1887 oweni Ameghino, 1887 \\
Acdestis lemairei, n. sp. & not known \\
Carlothentes chubutensis, n. gen. (Ameghino, 1897) & Palaeothentes chubutensis (Ameghino, 1897) \\
Palaeothentes boliviensis Patterson and Marshall, 1978 & Palaeothentes boliviensis Patterson and Marshall, 1978 \\
Palaeothentes primus (Ameghino, 1902) & Palaeothentes primus (Ameghino, 1902) \\
Palaeothentes marshalli, n. sp. & not known \\
Palaeothentes migueli, n. sp. & not known \\
Palaeothentes minutus Ameghino, 1887 & Palaeothentes minutus Ameghino, 1887 \\
Palaeothentes pascuali, n. sp. & not known \\
Palaeothentes intermedius Ameghino, 1887 & Palaeothentes intermedius Ameghino, 1887 \\
Palaeothentes lemoinei Ameghino, 1887 & Palaeothentes lemoinei Ameghino, 1887 \\
Palaeothentes aratae Ameghino, 1887 & Palaeothentes aratae Ameghino, 1887 \\
Propalaeothentes lepidus, n. gen. (Ameghino, 1891) & Palaeothentes intermedius Ameghino, 1887 \\
Propalaeothentes hatcheri, n. sp. & not known \\
Pilchenia lucina Ameghino, 1903 & Palaeothentes lucina (Ameghino, 1903) \\
Hondathentes cazador Dumont and Bown, in press & not known \\
\hline
\end{tabular}

New collections. - In 1982, the State University of New York at Stony Brook (SUNY) and the Museo Argentino Ciencias Naturales (MACN) in Buenos Aires initiated a joint program of field research to augment the tantalizing but scanty record of Miocene fossil platyrrhine primates from South America. Collecting operations began in the Colhuéhuapian part of the Sarmiento Formation at the locality of Sacanana (Rusconi, 1935; Fleagle and Bown, 1983) in 1982 and continued there through 1984, followed by investigations in the Trelew Member of the Sarmiento Formation (Simpson, 1935) in 1983-1985 and 1987. The latter work resulted in the discovery of La Cantera, a new Colhuéhuapian locality exceptionally rich in small mammals that is situated on the south side of the Rio Chubut near the town of Bryn Gwyn (Fleagle and Bown, 1983). Investigations were later expanded to include exposures of Santacrucian rocks in the valley of the Rio Pinturas (e.g., Ameghino, 1901-1902, 1906; de Barrio et al., 1984=Pinturas Formation of Bown et al., 1988a, and Bown and Larriestra, 1990) in 1984. Sites discovered that year and several new localities were worked the succeeding season and during 1987-1991. In 1987, Cárlos Ameghino's classic coastal Santa Cruz localities at Monte Observación and Monte León were visited and found to be so productive that they were worked successfully from 1987-1991. New fossil mammal localities of Santacrucian age were also established in rocks resembling the Pinturas Formation near Gobernador Gregores (in central Provincia de Santa Cruz) in 1988 and, slightly farther west, near Lago Cardiel in 1990. In 1992, collecting operations began in extensive exposures of the Santa Cruz Formation along the south barranca of the lower Río Chalia (=Río Sehuen), northwest of the coastal town of Cmte. Luis Piedrabuena.

In addition to a much enlarged knowledge of fossil platyrrhine primates that has resulted from the joint SUNY-MACN Patagonian expeditions (Fleagle and Bown, 1983; Fleagle et al., 1987; Fleagle, 1990), a wealth of new specimens of nonprimate fossil mammals was encountered. Among these are 719 fragmentary dentitions and isolated teeth of palaeothentid marsupials, a fig- ure somewhat more than four times as large as that of the available sample (168 specimens) of a decade earlier at the time of Marshall's (1980) revision of the group. The new collection comprises 104 specimens of Colhuéhuapian and 314 specimens of Santacrucian Palaeothentes (placed here in seven species), one specimen each of two new genera and species of Deseadan acdestines, and 213 specimens representing two species of Santacrucian Acdestis. Additionally, a new genus and species of Colhuéhuapian acdestine palaeothentid, Trelewthentes rothi (infra), is represented by 54 specimens from La Cantera in the Trelew Member of the Sarmiento Formation, and Loomis' (1914) Deseadan Callomenus praecursor is referred to the new genus Acdestoides. Ameghino's genus Pilchenia is resurrected for the sole specimen of the Deseadan palaeothentine species $P$. lucina, and the new genus Carlothentes is erected to accommodate Ameghino's (1897) Epanorthus chubutensis.

The Palaeothentidae are widely distributed geographically in Deseadan through Santacrucian faunas over much of southern Argentina. Because the new samples add appreciably to palaeothentid taxonomic diversity and to knowledge of dental variability within the group, and because an important new form is now known from Colombia, it is timely to reassess palaeothentid taxonomy, dental evolution, and phylogeny. Additionally, more detailed information is now available concerning the geographic and stratigraphic distribution of the Palaeothentidae. The size and importance of the new collection requires a general review of the family to assess both the evolutionary position of the new forms and their bearing on the organization of the Palaeothentidae.

Taxa of palaeothentids recognized in this study are listed in Table 1 .

Abbreviations and mensuration. - Abbreviations used in the text are: ACM, Amherst College Museum, Amherst, Massachusetts; AMNH, American Museum of Natural History, New York, New York; FMNH, Field Museum of Natural History, Chicago, Illinois; MACN, Museo Argentino Ciencias Naturales "Bernardino Rivadavia," Buenos Aires, Argentina; MLP, Mu-

FIGURE 2-Principal Deseadan (1) and Santacrucian (2-17) localities for Palaeothentidae in southern Patagonia, Argentina. 1, Cabeza Blanca; 2, valley of the Río Pinturas (see Bown and Larriestra, 1990, fig. 2 for detail); 3, Estancia La Cañada; 4, Lago Cardiel; 5, Gobernador Gregores; 6, Río Chalia (probably includes Sehuen locality of C. Ameghino and J. B. Hatcher); 7, Karaiken; 8, Cerro Centinela; 9, Monte León; 10, Quequa-quemada; 11, Monte Observación; 12, Coy Inlet; 13, Coy Aike; 14, Estancia La Costa; 15, Corriguen Aike; 16, Cape Fairweather; 17, Estancia Killik Aike. (Re-drawn from Bown and Larriestra, 1990, fig. 1.) 


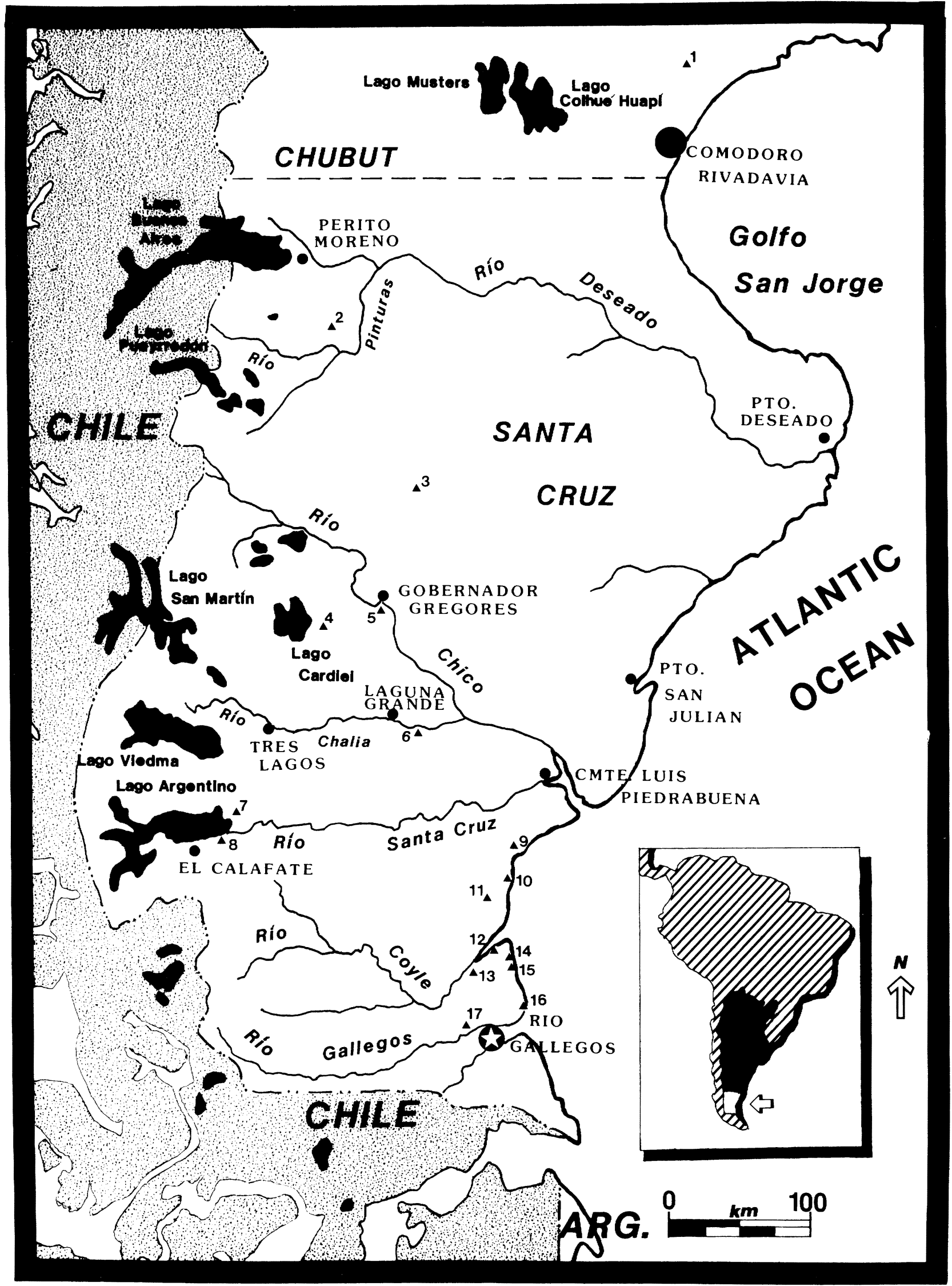




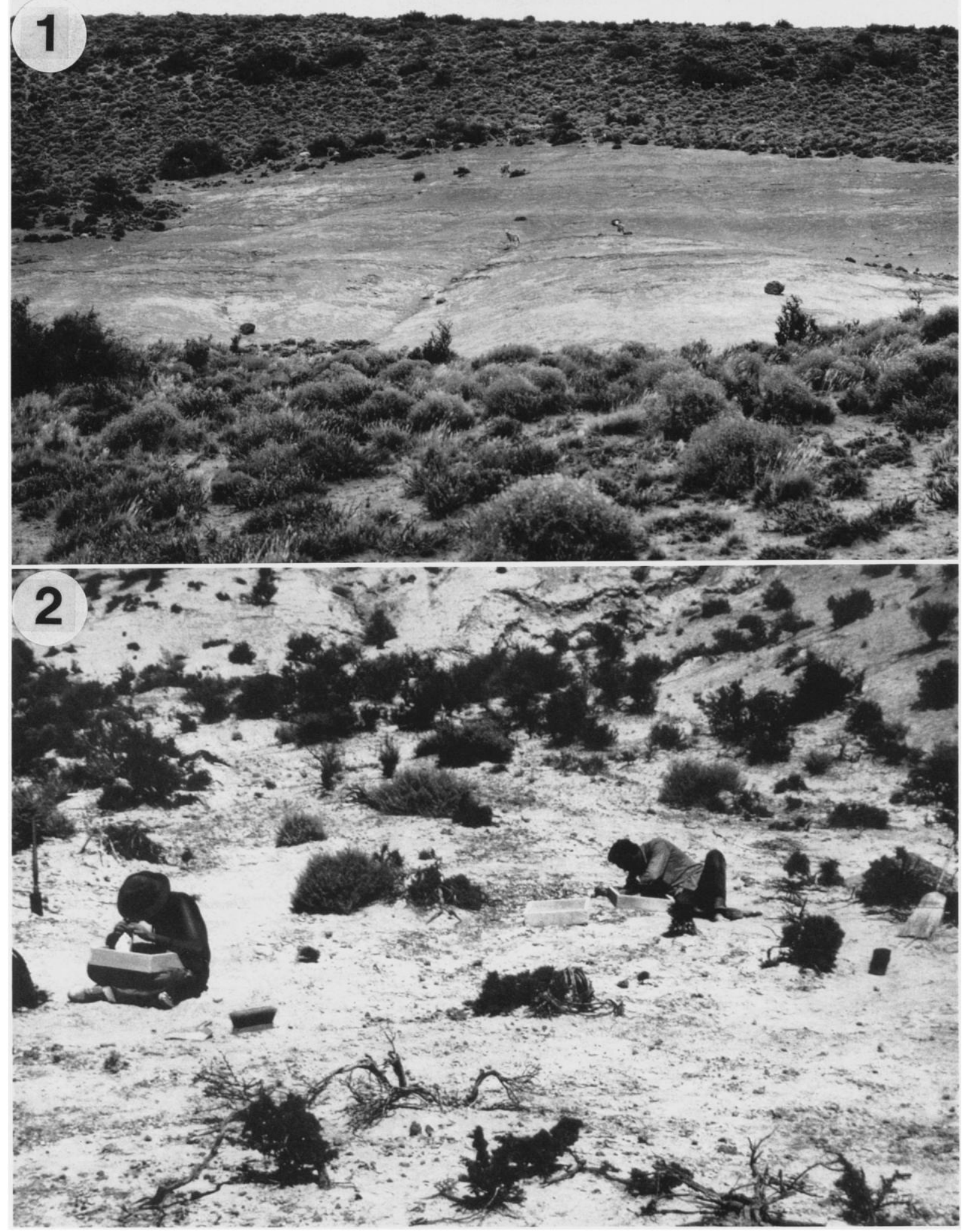

Figure 3-Exposures of the Sarmiento Formation at the localities of Sacanana (1) on the Pampa de Gan Gan (view approximately to north) and La Cantera (2) in the lower valley of the Rio Chubut (view approximately to west). 
seo de La Plata, La Plata, Argentina; MMP, Museo Municipal de Ciencias Naturales de Mar del Plata "Lorenzo Scaglia," Mar del Plata, Argentina; MNHN, Museo Nacional de Historia Natural, Santiago, Chile; $\mathrm{CH}$, collection from Provincia del Chubut (in MACN); SC, collection from Provincia de Santa Cruz (in MACN); ln, natural logarithm of length $\times$ width of molar; $L$, length (maximum anteroposterior dimension); $\mathrm{W}$, width (maximum transverse dimension, measured anteriorly on upper molars); DRm 1, ramal depth beneath lower first molar, measured on lingual side; MT, trigonid morphology; mm, millimeters.

Upper case letters are used to designate upper teeth and lower case letters are employed for lower teeth, such that P3 denotes the upper third premolar and $\mathrm{m} 1$ the lower first molar. The format for data pertaining to referred specimens and locality information follows the exemplary style of Marshall (1980) for ease of cross-referencing.

\section{LOCALITIES AND CORRELATION}

The new sample of palaeothentid marsupials discussed herein was collected from Deseadan rocks at Cabeza Blanca in Chubut Province, the Colhuéhuapian Sarmiento Formation (two localities), and from the Santacrucian Pinturas and Santa Cruz Formations (13 and 111 localities, respectively). In addition to the obvious and perhaps significant temporal disparity existing between sites in these rock units (and others known previously), palaeothentid localities are distributed across more than 130,000 $\mathrm{km}^{2}$ of Santa Cruz Province, Argentina (Figure 2). Moreover, rocks yielding the fossils were deposited in geographic settings ranging from precordilleran to coastal, and in paleoenvironments varying from aeolian pyroclastic to fluvial. Naturally, the palaeothentid component of the Deseadan-Santacrucian caenolestoid fauna varies significantly over its considerable temporal and geographic range (Figure 2), but it has hitherto been impossible to ascribe this variability to different relative ages, paleobiogeography, paleoenvironment, or some combination of those controls. Placing palaeothentid distributions in correct geologic and temporal perspective relative to one another is necessary to elucidate the relative imports of influences that may have affected them, and what is known of the sedimentary paleoenvironments and taphonomy of the principal Colhuéhuapian and Santacrucian palaeothentid sites is discussed briefly here.

Sacanana.-(Colhuéhuapian; Figure 1, locality 2.) Fluvially reworked pyroclastic sediments mapped as Sarmiento Formation (A. Lizuain, personal commun.) are exposed on and surrounding the Pampa de Gan Gan in north-central Chubut Province, Argentina (Figure 1), where they are interbedded with basaltic extrusive volcanic rocks. Vertebrate fossils from the Pampa de Gan Gan, including the type skull of the ceboid primate Tremacebus harringtoni (Rusconi), were first described by Rusconi (1935) from limited exposures near Cerro Sacanana (see also Hershkovitz, 1974; Fleagle and Bown, 1983). These outcrops were revisited by us in 1982, 1983, and 1984, and a single specimen of an acdestine palaeothentid, referred here to the new genus and species Acdestodon bonapartei, was recovered from our Sacanana locality 2 (Figure 3.1 ). This site is additionally important because of the extraordinarily large numbers of skulls and partially articulated skeletons of small-medium size Colhuéhuapian mammals that occur there (Fleagle and Bown, 1983).

Although exposures are poor and limited in the Cerro Sacanana area, presence of epsilon cross-stratified volcanic sandstone and alternating sets of thinly bedded volcanic sandstone and mudrock point to deposition of reworked pyroclastic materials on point bars. Paleosol development (though of very immature soils) is indicated by intense bioturbation, rhizoliths, and discrete trace fossils of a vertebrate and an unknown insect. The high concentration, dispersion, and orientation of vertebrate remains, the geometry of the vertebrate fossil-bearing deposit, what appear to be several generations of ball-and-pillow and tepee structure development, as well as general intense bed deformation are indicative of accumulation of the vertebrate remains in quicksands, probably over several hundreds or even thousands of years.

The taphonomy of Sacanana localities 2 and 3 is discussed more fully by Bown and Powers (manuscript).

La Cantera. -(Colhuéhuapian; Figure 1, locality 3.) The Trelew Member of the Sarmiento Formation (Simpson, 1935; Mendia and Bayarsky, 1981) is well exposed on the south barranca of the lower valley of the Rio Chubut, near Gaiman, in the coastal region of northeastern Chubut Province, Argentina (Figure 1). Simpson (1935) provided the first accurate and detailed account of the geology of the Trelew Member, and Bown and Powers (manuscript) offered a detailed interpretation of the sedimentology and geologic history of the Sarmiento Formation in the Gaiman area. The Trelew Member is composed of aeolian and fluvially reworked aeolian pyroclastic sandstone and mudrock that accumulated in the channels and on the floodplains of meandering streams (Bown and Powers, manuscript). Nearly all sediments of the Trelew Member were modified by penecontemporaneous soil (paleosol) development.

The locality of La Cantera (Figure 3.2; Fleagle and Bown, 1983) occurs in the lower part of the Trelew Member and has yielded numerous teeth and several jaws of small Colhuéhuapian mammals. Among these are teeth of a ceboid primate, $\mathrm{cf}$. Dolichocebus gaimanensis (Fleagle and Bown, 1983; Fleagle and Kay, 1989), a great many teeth and a few jaws of the acdestine palaeothentid Trelewthentes rothi $\mathbf{n}$. gen. and sp. (infra) and of the palaeothentines Palaeothentes marshalli $\mathrm{n}$. sp. and P. migueli n. sp. (infra).

The largest concentrations of fossils occur in the upper part of a single paleosol (A horizon and upper part of B horizon) in two somewhat localized "pockets," although fossils are common in this paleosol throughout its area of exposure (about $20 \mathrm{~km}$ ). The positions of the fossil concentrations in the paleosol, together with the composition and condition of the remains (dominance of teeth and jaws over postcrania, common presence of tooth punctures and bite marks on the bones, disarticulation, lack of long bone shafts, and broken but not abraded bonessee Bown and Powers, manuscript), suggest a gradual, attritional accumulation of the bones in a cumulative soil throughout the time of soil formation (e.g., Bown and Kraus, 1981).

Río Pinturas. -(Santacrucian; Figure 1, locality 5, and Figure 2, locality 2.) The Pinturas Formation (Bown et al., 1988a; Bown and Larriestra, 1990) is a pyroclastic and epiclastic aeolian deposit of Santacrucian age exposed in several geographically isolated areas in the upper valley of the Rio Pinturas, south of the town of Perito Moreno, in precordilleran northwest Santa Cruz Province, Argentina. The Pinturas Formation is divisible into three sequences by major intraformational erosional unconformities: 1) a lower sequence typified by immature paleosols and/ or carbonaceous volcaniclastic mudrocks at the base and top and very mature paleosols in the middle; 2) a middle sequence dominated by one or two units of epiclastic nonvolcanic paleodune sand and with varying amounts of volcaniclastic mudrock with immature paleosols; and 3) an upper sequence of generally massive volcaniclastic mudrock with very immature paleosols. Paleoenvironmental evidence (Bown and Larriestra, 1990; Bown and Laza, 1990) indicates that the lower sequence of the Pinturas Formation accumulated under warm, moist, subtropical forest 


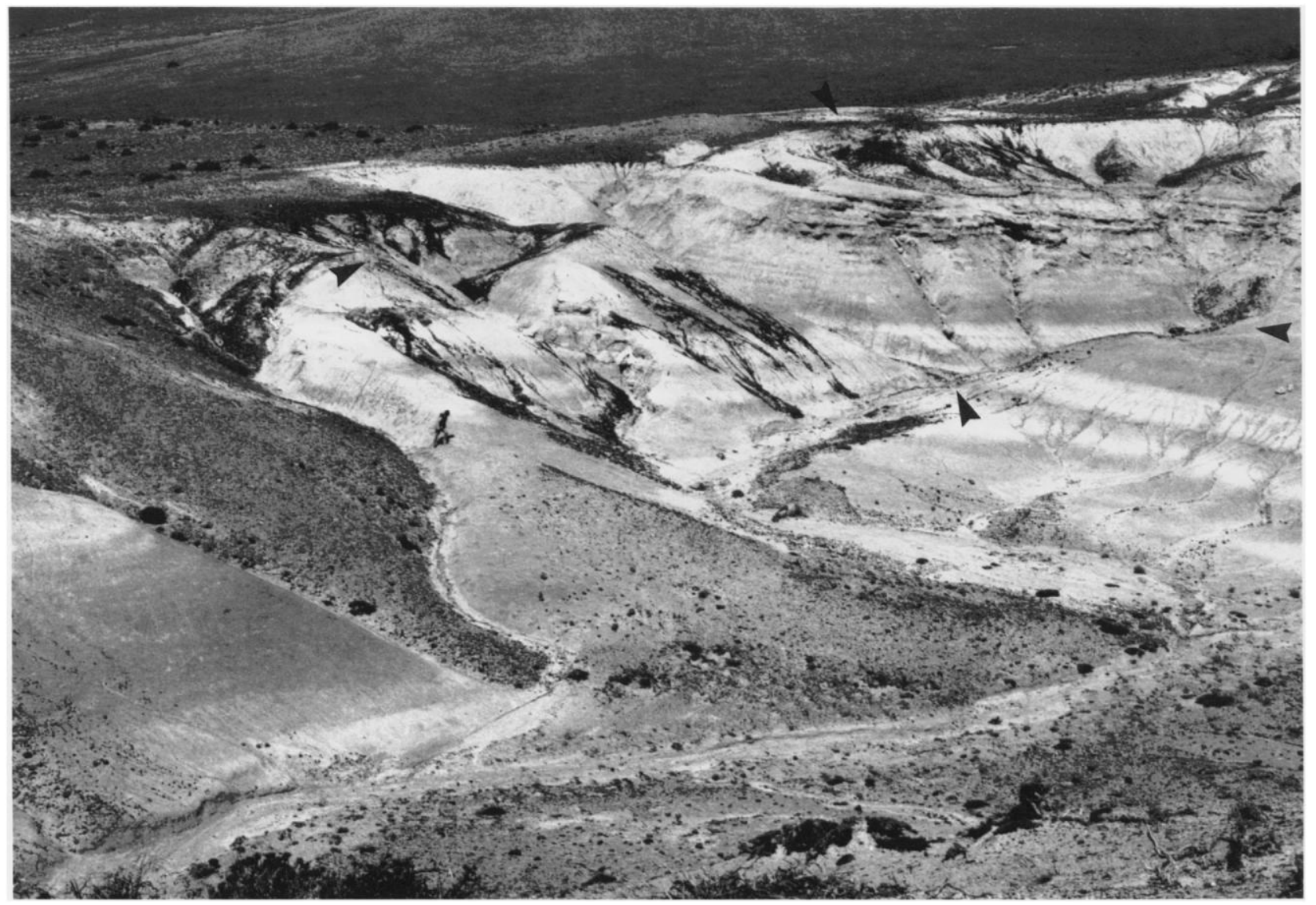

Figure 4-Exposure of Pinturas Formation at Estancia El Carmen, valley of the Río Pinturas (view approximately to southwest). Arrows mark general areas of fossil concentration.

conditions and that increased pyroclastic production in later Pinturas time may have led to at least periodically drier conditions with perhaps some more open areas.

Fieldwork in the last eight years has resulted in the discovery of 10 highly productive fossil vertebrate sites at eight localities in the Pinturas Formation: three sites at Estancia El Carmen (Figure 4) and one site each at Portezuelo Sumich Norte, Portezuelo Sumich Sur, Estancia Los Toldos, Cauce Seca, Cerro de los Monos, Loma de la Lluvia, and Loma de las Ranas (Estancia Ana Maria). It is from these sites that all of the Pinturas palaeothentids, as well as all platyrrhine primates (Fleagle, 1990), were found. Localities of earlier collections made from the Pinturas Formation are unknown.

Nearly all of the Pinturas paleosols yield fossil vertebrates, with the exception of the most mature paleosols in the lower sequence of the formation. Fossils are probably absent there due to intense, destructive pedogenetic chemical modifications over considerable periods of time. Elsewhere, measured stratigraphic sections and analyses of fossil remains indicate that the most important Pinturas fossil vertebrate concentrations occur: 1) in the A horizons of immature to moderately mature paleosols (Estancia El Carmen, Estancia Los Toldos, Loma de la Lluvia, Cerro de los Monos, Loma de las Ranas [Estancia Ana Maria], and, probably, Portezuelo Sumich Sur); and 2) in paleosols developed at the floors of paleovalley scours (Portezuelo Sumich Norte, Estancia El Carmen [middle locality], and Cauce Seca). Both types of accumulation were attritional and resulted in the gradual incorporation of remains into a developing soil (paleosol) over time.
Exposure of the Pinturas Formation is discontinuous and it is impossible to correlate fossil localities directly by walking out marker beds. Sections of all exposed Pinturas rock were measured at each of the fossil localities. These were then correlated to one another by identification of marker units and marker unconformities. Because a relatively great percent of Pinturas time was erosional (lacunal time) or was occupied in paleosol development (hiatal time), correlation of the geographically disparate Pinturas fossil vertebrate localities (Table 2) is timestratigraphic (rather than rock-stratigraphic) and is based on relative paleosol maturities (see Kraus and Bown, 1986, and Bown and Kraus, 1987, on paleosol maturity and time, Bown and Kraus, in press, and section below on empirical temporal reconstruction, and Bown and Larriestra, 1990, on time-stratigraphic reconstruction of the Pinturas Formation).

Estancia La Cañada, Gobernador Gregores, and Lago Cardiel.-(Santacrucian; Figure 2, localities 3-5.) Rocks strongly resembling those of the Pinturas Formation and yielding few, but important, specimens of palaeothentid marsupials outcrop in a few areas between the upper Rio Pinturas valley and the Atlantic coast. Sediments at a small exposure on Estancia $\mathrm{La}$ Cañada (Figures 2, 5.1), northeast of the road junction termed Las Horquetas, mirror those on either side of the unconformable contact of middle and upper Pinturas rocks at Cauce Seca in the upper valley of the Río Pinturas, farther north. Fossils at La Cañada appear to have accumulated in paleosols that developed on an erosional surface bordering a small lake or pond.

To the south, a few kilometers southwest of the town of Gobernador Gregores in central Santa Cruz Province, a large ex- 
TABLE 2-Correlation of fossil vertebrate localities in the valley of the Río Pinturas (Pinturas Formation), and at Monte Observación and Monte León (Santa Cruz Formation), coastal Provincia de Santa Cruz. TV = temporal value (see text) in combined Pinturas-Santa Cruz section (assumption - that top of Pinturas Formation is stratigraphic equivalent to base of Santa Cruz Formation); Estaca \# = numbered stakes driven in at specific localities; Meter level = meters above base of exposed section of Santa Cruz sections at Monte Observación and Monte León. The temporal reconstruction of the Pinturas Formation was given by Bown and Larriestra (1990).

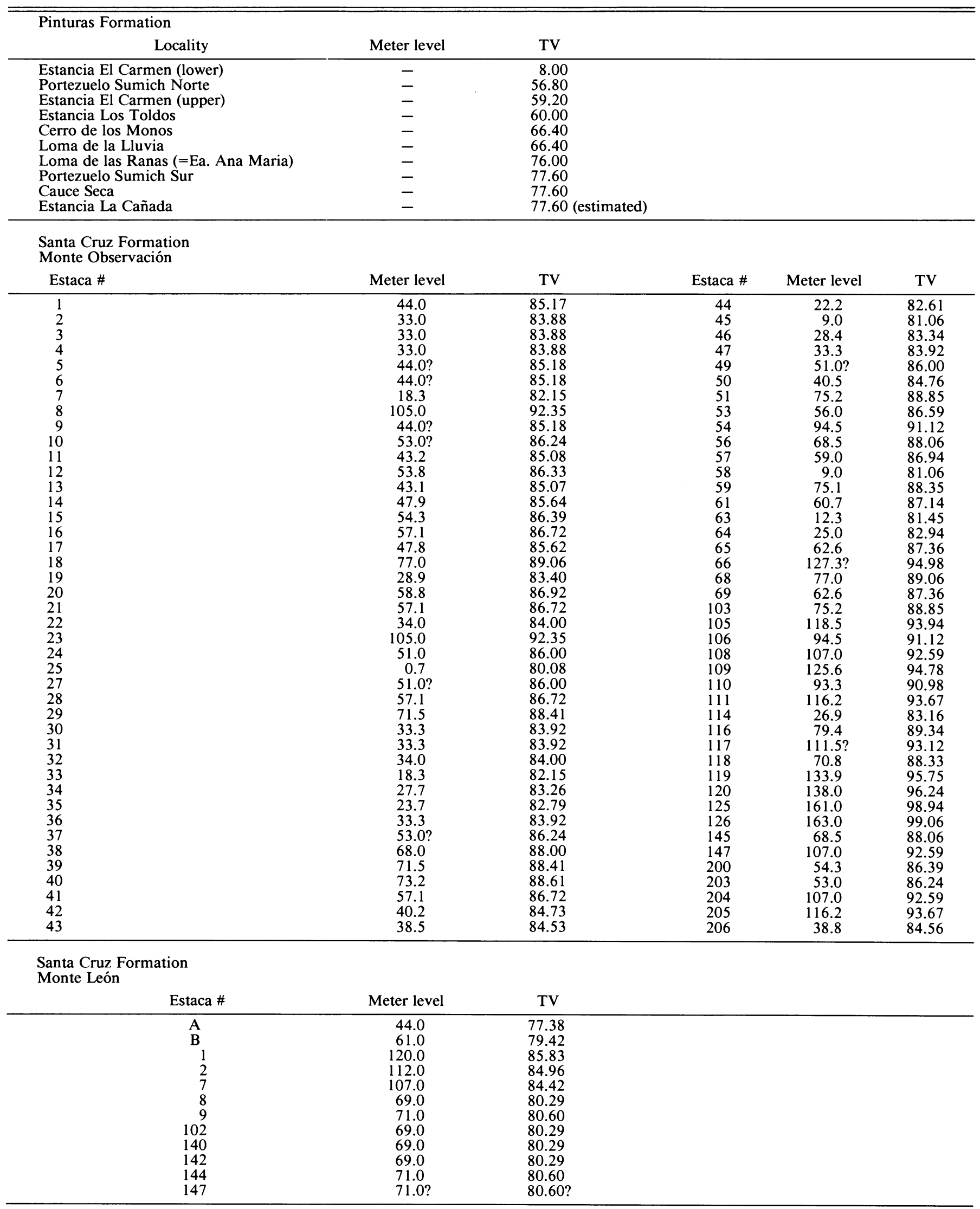


posure of at least $150 \mathrm{~m}$ of rocks resembling the Pinturas Formation in its type area is developed on a minor, east-flowing tributary of the Río Chico (Figure 5.2). Like the Pinturas Formation, these rocks contain a large volume of unreworked pyroclastic tuff, some very mature paleosols, and at least one level of epiclastic paleodune sand. However, unlike the Pinturas Formation, fluvial sandbodies occur and intraformational unconformities are absent. Four sites yielding fossil vertebrates (three sites with a total of four specimens of palaeothentids) were located at the Gobernador Gregores locality. These sites appear to span levels that, in the valley of the Rio Pinturas, would be placed in the lower sequence of the Pinturas Formation between Estancia El Carmen (lower) and the base of the lowest paleodune sand (base of middle sequence). Because no detailed stratigraphic work has been accomplished in the Gobernador Gregores area, the stratigraphic relationships of fossil vertebrate sites there to those of the type Pinturas Formation are highly tentative.

About $50 \mathrm{~km}$ southwest of Gobernador Gregores, adjacent to the eastern shore of Lago Cardiel (Figure 5.3), a large area of rocks mapped by Ramos (1982) as Santa Cruz Formation is exposed. These rocks differ from those of the coastal (and type) Santa Cruz Formation and resemble the Pinturas Formation in that they contain more paleodune deposits, several relatively mature paleosols, and a greater volume of unmodified pyroclastic material. They differ from Pinturas rocks in the lack of major intraformational erosional unconformities and in the presence of large alluvial sandbodies. Unlike the exposures at Gobernador Gregores, the sequence at Lago Cardiel offers no suggestion of correlation with specific parts of the type Pinturas Formation. Five sparsely productive fossil mammal sites were located at Lago Cardiel, yielding but three fragmentary specimens of palaeothentids. Of these sites, three appear to be of paleosol origin, one is in a crevasse channel sandstone, and the last yielded water-worn bones and teeth from an epiclastic granule and mud intraclast gravel.

Monte Observación. -(Santacrucian; Figure 1, locality 6, and Figure 2, locality 11.) The Miocene Santa Cruz Formation is developed over much of the south of Patagonian Argentina (e.g., Ameghino, 1889; Feruglio, 1938; Russo and Flores, 1972). It is best exposed in sea cliffs on the Atlantic coast and along the courses and tributaries of the Río Chico, Río Chalia, Río Santa Cruz, Río Coyle, and Río Gallegos. From the Pinturas Formation, the Santa Cruz Formation differs in: 1) having a lesser volume of unrecycled pyroclastic sediment; 2) a greater volume of fluvially deposited epiclastic sandbodies; 3) significant marine intercalations (in its lower part); 4) absence of major intraformational erosional unconformities; 5) a lesser volume of epiclastic paleodune sand; and 6) the absence of mature paleosols. In general, Santa Cruz rocks are typified by more continuous deposition than was characteristic of the Pinturas Formation. This is reflected by a sequence of superposed volcaniclastic mudrocks containing immature paleosols; the rocks accumulated and the paleosols formed on an essentially featureless coastal alluvial plain (about 65\%), shoestring and ribbon channels filled with both epiclastic and volcanic sand and sandy granule and pebble gravel (about 10\%), thin-bedded volcaniclastic sandy mudrock, possibly of lacustrine origin (about 15\%), and beds of relatively unaltered tuff (about $10 \%$ ).

One of the stratigraphically most continuous $(170 \mathrm{~m})$ and areally most extensive (about $8 \mathrm{~km}$ ) exposures of the Santa Cruz Formation is at Monte Observación (Figure 6.1), north of the town of Río Gallegos in coastal Santa Cruz Province, Argentina (Figures 1,2). This locality is perhaps also the richest known of Santacrucian age in South America. Santa Cruz deposition at Monte Observación appears to have consisted of numerous cycles of 1) pyroclastic tuff deposition, 2) fluvial reworking of tuff by overbank flooding of streams with distant, epiclastic sources, and 3) modification of reworked volcaniclastic alluvium by pedogenesis. With the exception of channel sands and gravels and the probably lacustrine sediments, nearly every unit in the Monte Observación section has been pedogenetically altered. The few unaltered tuffs were preserved by means of relatively rapid, yet still punctuated, episodes of pyroclastic production in which intervals of nondeposition were too brief to permit appreciable pedogenetic modification.

Santa Cruz deposition appears to have been accomplished under relatively warm, humid conditions. Some areas of forest were present as is indicated at two levels by numerous calcareous steinkerns of trees, although burrows of solitary bees and nests of scarabeid dung-beetles suggest at least some more open areas (Genise and Bown, in press), as do remains of large phororhacid birds (Chiappe, 1991).

The base of the Santa Cruz Formation is not exposed in the immediate vicinity of Monte Observación; however, distinctive marker beds present at that locality and to the north at Monte León suggest that the base of the formation is but a few meters beneath the level of Monte Observación estaca \#25 (Figure 6.2, and see below).

Fossil vertebrates are abundant in the upper (A) horizons of nearly all of the paleosols at Monte Observación. More rarely, fossils are encountered in the channel sands and gravels. Most of the paleosols are very immature and consist of an organicrich, devitrified A horizon and a clay enriched but otherwise essentially unaltered lower $(B+C)$ horizon. The $A$ horizon is incompetent, whereas the lower, less altered horizon is relatively resistant, causing the paleosols to weather into a series of discrete, steplike benches (Figure 6.3). Restriction of fossil collecting efforts to these discrete benches on what are otherwise very steep slopes has facilitated accurate biostratigraphic control.

More than 100 fossil vertebrate sites have been established in the Santa Cruz Formation at Monte Observación since 1987, and 84 of those have been correlated to measured sections (Figure 7; Table 2). The fossil sites are identified by numbered metal stakes (termed estacas in systematics section herein and on labels in the MACN collections) that were driven into the rock at the top of the paleosol bench where the fossils were collected. The stakes therefore identify both sites as well as individual productive levels. The new Monte Observación localities have also been correlated by time-stratigraphic means (Table 2), utilizing the technique described in a following section. Several thousand fossil mammal specimens from Monte Observación are now correlated by both measured stratigraphic sections and timestratigraphy, including 362 specimens of Palaeothentidae. Specific localities of substantial earlier collections made at Monte Observación are unknown.

Río Chalia.-(Santacrucian; Figure 2, locality 6.) About 400 $\mathrm{m}$ of the Santa Cruz Formation is developed in spectacular badlands on the high barranca south of the lower Rio Chalia (Figure 6.4), about 100-160 km northwest of the town of Cmte. Luis Piedrabuena in south-central Provincia de Santa Cruz. The best exposures occur on estancias Viven Aike and Las Sauces, 

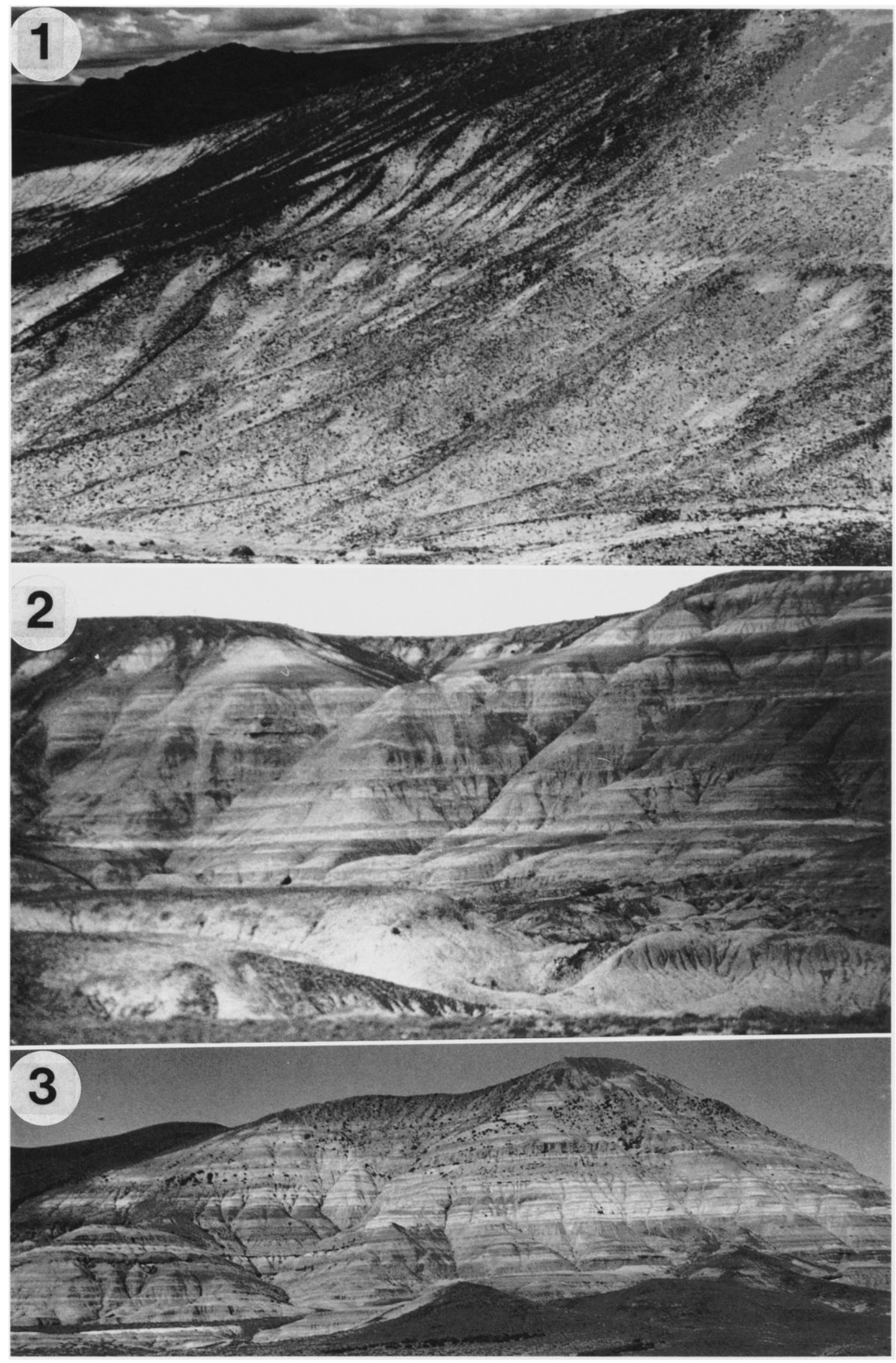

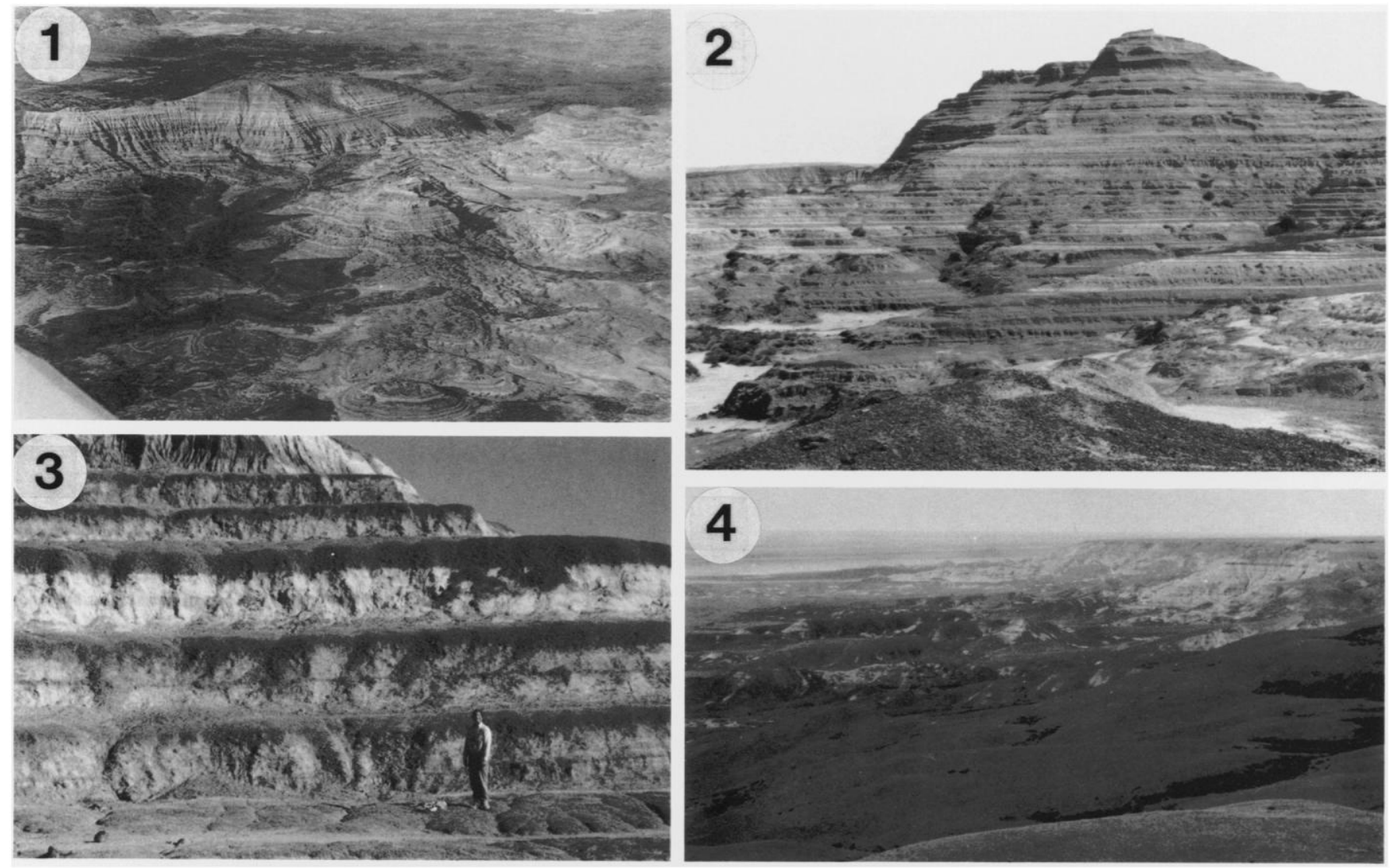

Figure 6-Exposures of the Santa Cruz Formation at Monte Observación, coastal Santa Cruz Province, and on the Río Chalia, central Santa Cruz Province. 1, aerial photograph of exposures at Monte Observación, view approximately to NE; 2, east side of Monte Observación fossil vertebrate locality marked by estaca \#25 on light-colored flats at floor of exposure (view approximately to west); 3 , paleosols at estaca \#36, Monte Observación, showing discrete benches formed by weathering at top of each (view approximately to west); 4, exposures of the Santa Cruz Formation on the barranca south of the Rio Chalia, estancias Viven Aike and Las Sauces (view approximately east-northeast).

between Estancia La Rosita (on the west) and Estancia La Julia (on the east). Preliminary prospecting at five sites in this vast area (estacas 1-5) resulted in the recovery of 32 specimens of palaeothentid marsupials, including the type and only specimen of Propalaeothentes hatcheri $\mathrm{n}$. sp. Fieldwork also indicates that most of the Santa Cruz Formation is exposed along the Rio Chalia and that certain stratigraphic marker units may be directly correlatable with their counterparts at Monte Observación and Monte León.

Slumps and springs below the crest of the Rio Chalia escarpment and exposures beneath them at the western limit of Estancia La Rosita match closely Hatcher's (1903, p. 112-114) description of his "Sehuen" locality-presumably the same as the Sehuen collected by Cárlos Ameghino in 1890-1892 (e.g., F. Ameghino, 1891).

Monte León. -(Santacrucian; Figure 1, locality 6, and Figure 2 , locality 9.) The second most important coastal locality in the Santa Cruz Formation is at Monte León (Figure 8), south of the town of Cmte. Luis Piedrabuena and a few kilometers north of Monte Observación (Figure 2). Santa Cruz rocks at Monte León differ from those at Monte Observacion only in the somewhat greater volume of channel sandstones and gravels and a lesser volume of the thin-bedded, possibly lacustrine strata. The base of the Santa Cruz Formation is well exposed at Monte León, where it lies variably with conformity or erosional unconformity on 45-60 m of largely nearshore marine volcaniclastic mudrocks, shales, sandstones, and tuffs of the Monte León For- mation of the Patagonian Group (Grupo Patagónica-see Camacho, 1974). The uppermost $15 \mathrm{~m}$ of the Grupo Patagónica contains both fluvial mudrocks and tuffs with paleosols, as well as thin intercalations of marine sediments, some of which have concretions yielding the Patagonian oyster Ostrea hatcheri (Figure 9).

Fifteen fossil mammal sites have been discovered at Monte León since $1987 ; 12$ of these are tied to measured sections (Figure 9 and Table 2) and have yielded 85 specimens of $\mathrm{Pa}-$ laeothentidae. Sites A, 1, 2, 7, 9, and 147 are concentrations in the A horizons of mollic paleosols, whereas fossils from sites B and 102 occur in the upper parts of fluvial sandbodies. Which of these sediments yields fossils at sites 140 and 142 is uncertain; they are either from the upper parts of fluvial sandbodies or from the mollic paleosols directly overlying those sandbodies.

The consistent stratigraphic distribution of marker tuffs, fluvial sandstones, and persistent nodular zones in outcrops at both Monte León and Monte Observación permit direct correlation of Santa Cruz rocks and fossil sites at these two localities. These data indicate that estaca 142 at Monte León and estaca 25 at Monte Observación probably occur in the same sedimentologic unit (Figure 9). Other Monte León sites were correlated with sites at Monte Observación by assessing their proportionate stratigraphic positions between marker beds common to both localities.

Specific localities for earlier collections made at Monte León are unknown. We were also unable to identify the rich site Cárlos 

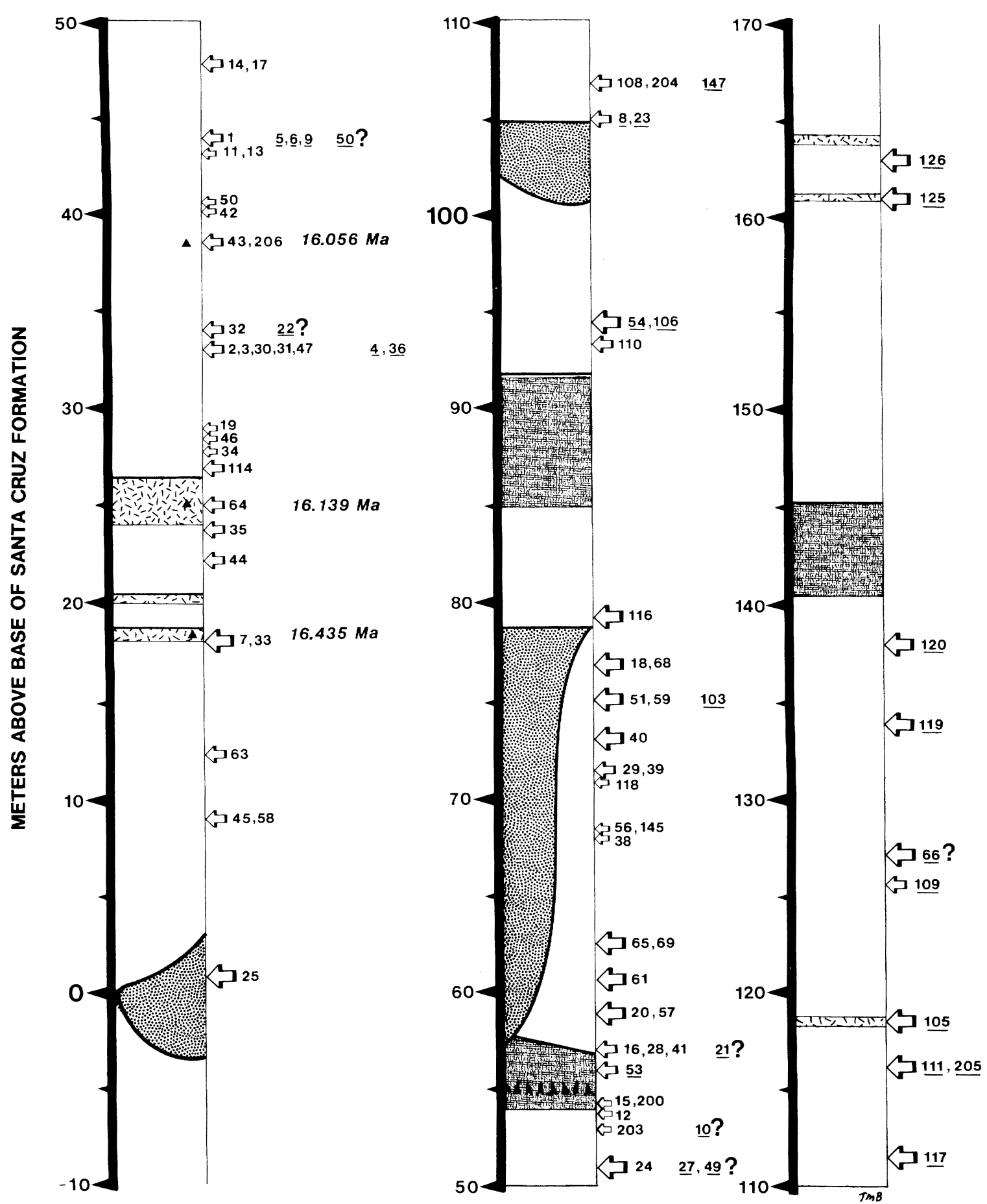

FIGURE 7-Stratigraphic section of coastal Santa Cruz Formation at Monte Observación, showing correlation of fossil vertebrate localities (numbered arrows) and radiometric age determinations (black triangles). Marker lithologies depicted are: tuff (dashes); gravelly sandstone (dots); and volcanic mudstone (shaded). Numbers to left of columns denote meter levels discussed in text.

Ameghino termed "La Cueva," tentatively placed by Marshall (1976, fig. 2) south of Monte León, between Isla Monte León and Cañadon Jack (though with considerable qualification). If "La Cueva" indeed refers to a nearby cave or grotto, at least two possibilities present themselves in the immediate vicinity of the Monte León landmark. The first is a deep, vertically perforated wave-cut grotto just north of Monte León itself, and the second is a stack with a wave-cut window situated a few hundred meters south of the Lóberia near Isla Monte León. Either of these sites would identify Ameghino's "La Cueva" with the most extensive exposures in the area, about 1.0-1.5 $\mathrm{km}$ west of Monte León rock, and with those termed "Monte León" by us in this work. This premise offers no solution, however, because it would instead leave the site of Cárlos Ameghino's "Monte León" locality in doubt. The exposures we have worked and term "Monte León" are the only good, richly fos- 


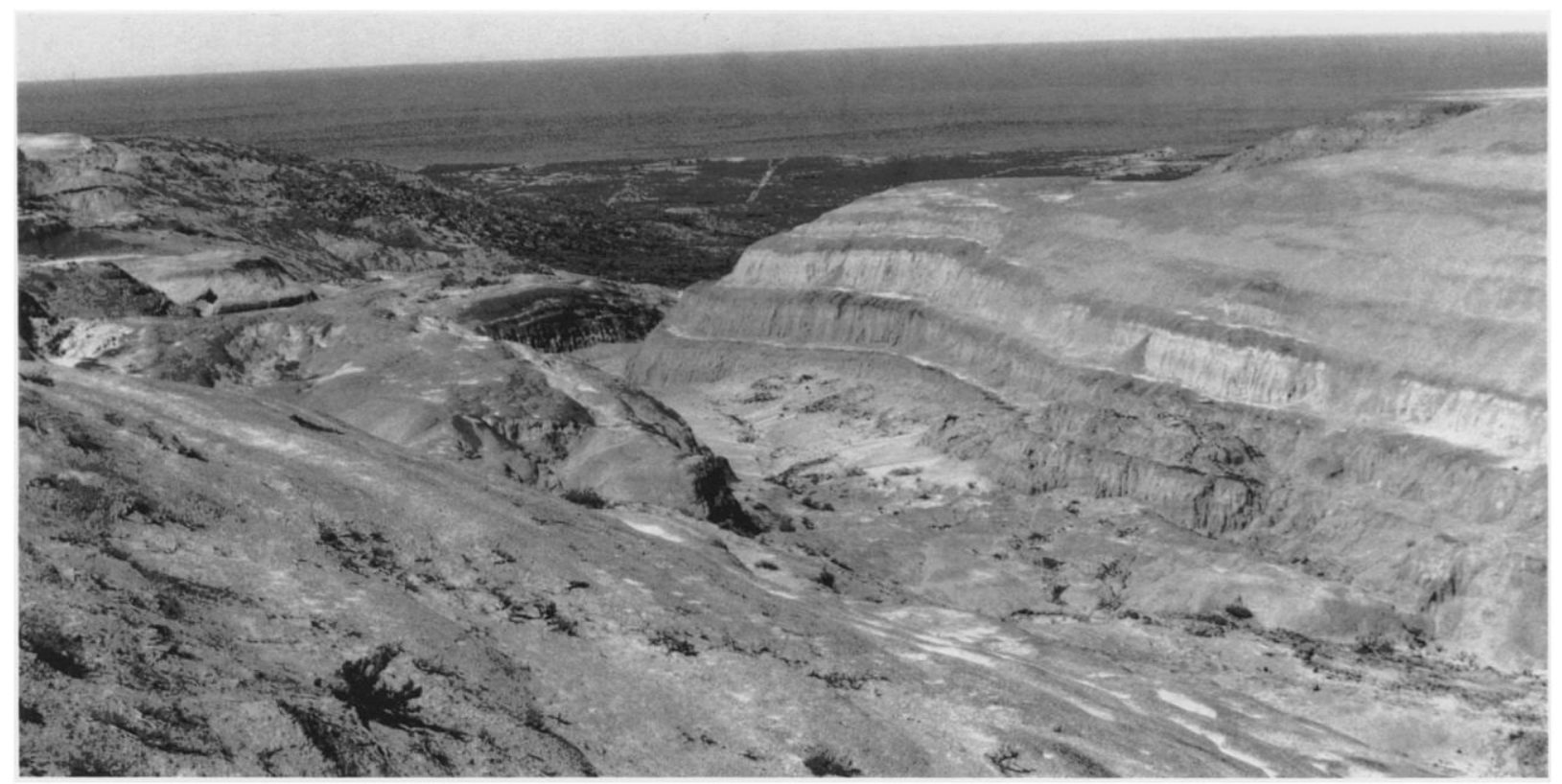

Figure 8-Exposures of the Santa Cruz Formation in vicinity of estaca \#140 at Monte León, coastal Santa Cruz Province. Collections were made from the floor of the small valley (view approximately to southwest).

siliferous exposures in the vicinity of the landmark rock and, judging from the early collections, both Ameghino's "Monte León" and "La Cueva" were very productive sites. Whatever the position of "La Cueva" it is an important site and, from examination of specimens in the MACN collection, must be identified with an exposure (and possibly a quarry) that yielded exceptional material, including several jaws, two partial skulls, and some postcranial bones of palaeothentids, all with a black sand matrix.

Correlation of the Pinturas and Santa Cruz Formations. - In 1900-1902, Florentino Ameghino referred vertebrate fossilbearing rocks examined by his brother Cárlos in 1891 in the valley of the Rio Pinturas to his (1889) "formación Santacruceana." After further study, F. Ameghino (1906) concluded that the Rio Pinturas fossil mammals differed from those of his "Santacruzienne" fauna, belonging instead to his older "Astrapothericulense" fauna. Frenguelli (1931) was the first to suggest that the Rio Pinturas mammal fauna contained some Colhuéhuapian elements and, subsequently, Castellanos (1937) designated the term "Pinturense" for a new mammal age intermediate between the "Colhuéhuapense" and "Santacrucense." Pascual et al. (1965) and Pascual and Odreman Rivas (1971) transferred Ameghino's "Astrapothericulense" fauna to the "Santacrucense" (Santacrucian), echoing the earlier view of Wood and Patterson (1959), and one subsequently accepted by Marshall (1976), Marshall et al. (1977, 1983), Marshall and Pascual (1978), de Barrio et al. (1984), and Pascual et al. (1985) as early Santacrucian. An early Santacrucian age for the Pinturas Formation, 18.0-16.5 Ma in the geochronology of Marshall et al. (1986), is appreciably younger than estimates for the base of the Santa Cruz Formation suggested by earlier authors (e.g., Savage and Russell, 1983), but considerably older than the 16.6-13.3 Ma dates offered by Bown et al. (1988b) and Bown and Larriestra (1990).

The principal exposures of the Pinturas Formation, its approximate lithological and sedimentological equivalents, and rocks yielding representatives of Ameghino's "Astrapothericulense" fauna are: 1) valley of the Río Pinturas; 2) Gobernador
Gregores; 3) Lago Cardiel; 4) Estacia Videlita; and 5) Karaiken (=Estancia La Laurita, see Marshall and Pascual, 1977). Unfortunately, and despite the above valiant efforts to reliably correlate the Pinturas and Santa Cruz Formations, existing solutions remain contradictory. Furthermore, faunal correlations are complicated by paleogeography-Rio Pinturas is in the elevated Andean precordillera whereas the principal mammal localities of the Santa Cruz Formation are coastal and situated several hundred kilometers to the east. The best studied cooccurring fossil mammals are the platyrrhine primates (Fleagle, 1990; Fleagle et al., 1987) and the Palaeothentidae (herein), and neither offers a convincing solution. Primates occurring on the coast do not occur at Pinturas and the dispersion of the palaeothentids (exceedingly rare in the Pinturas Formation and abundant in the Santa Cruz Formation; Bown et al., 1990) suggests control by geographic or paleoenvironmental factors, as well as possible temporal differences.

The palaeothentid evolutionary trends presented here offer little more information because all of these were at times disrupted by unconformities or catastrophic tuff deposition (Bown and Anderson, manuscript), after which more generalized morphologies commonly replaced advanced morphologies. Patterns of palaeothentid evolution suggest only that the Pinturas and Santa Cruz Formations are not vastly different in age and are consistent with either of the earlier hypotheses that they are 1) equivalent in age or 2) that some of the Pinturas Formation is marginally the older.

Earlier geological solutions have fared no better. The Pinturas and Santa Cruz Formations differ stratigraphically and sedimentologically to an extent that prohibits correlation of units, unconformities, and even sequences (Bown and Larriestra, 1990). Radiometric determinations on rocks at several localities in the type Santa Cruz Formation (Marshall et al., 1977, 1983, 1986; Marshall and Pascual, 1978) are inconsistent and contradictory, and, by virtue of its inconsistently very young age determinations, the only published whole rock geochronology of the Pinturas Formation (Bown et al., 1988b; Bown and Larriestra, 1990) is almost certainly incorrect. 


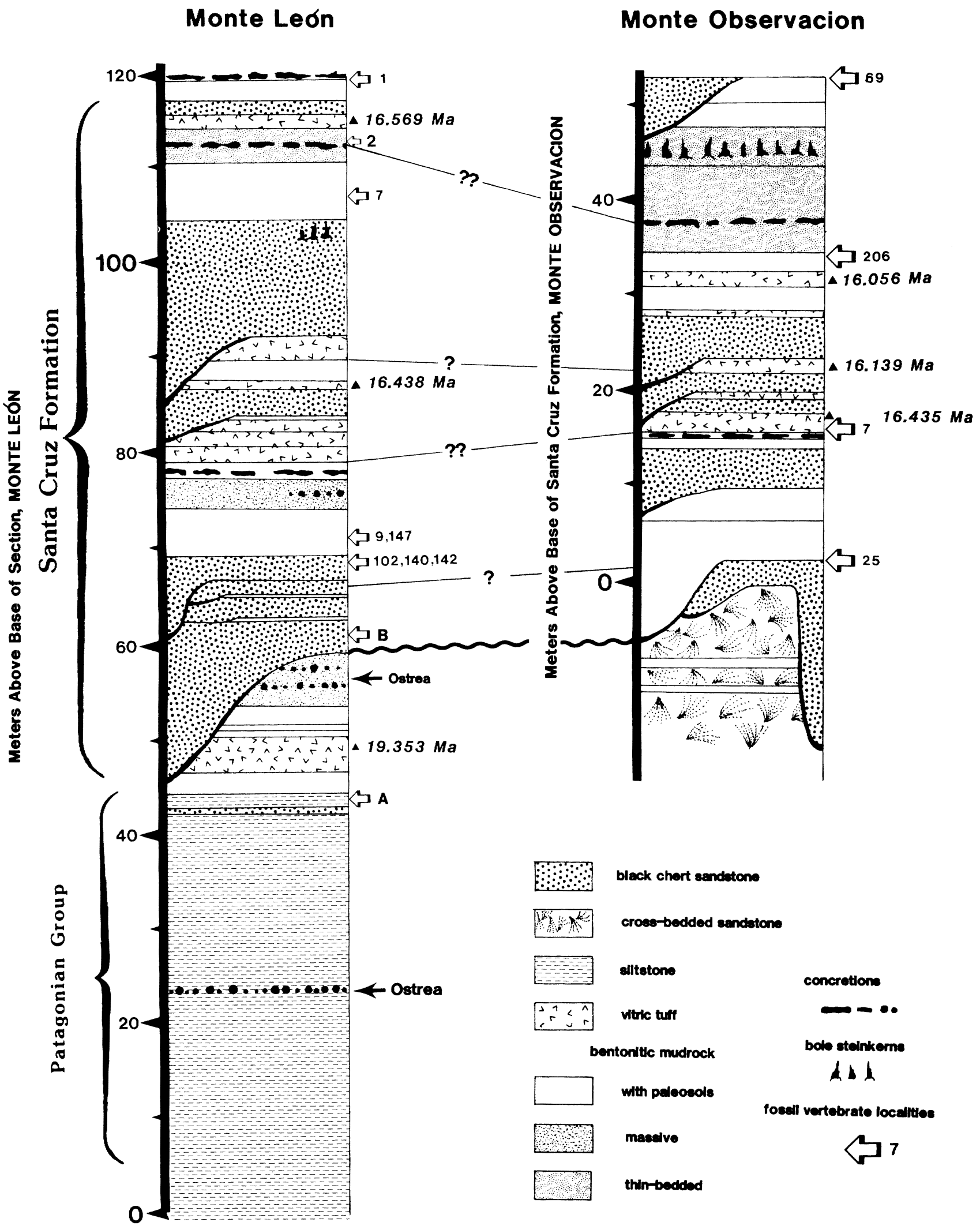

FIGURE 9-Stratigraphic sections of coastal Santa Cruz Formation showing correlations of fossil vertebrate localities (numbered arrows) and radiometric age determinations (black triangles) between Monte León and Monte Observación. Numbers at left of columns denote meter levels discussed in text. 
TABLE 3-Comparison of single crystal plagioclase (p) and hornblende (h) radiometric dates from tuffs from the Monte Leon, Pinturas, and Santa Cruz Formations, Provincia de Santa Cruz, Argentina, with temporal values $(=T V)$ obtained by paleosol analysis. Dates are placed in stratigraphic order. Radiometric data from C. Swisher, Institute of Human Origins, Berkeley, California. Additional data on samples available on request.

\begin{tabular}{|c|c|c|}
\hline $\begin{array}{l}\text { Monte León Fm. } \\
\text { (Gpo. Patagonia) }\end{array}$ & Pinturas Fm. & Santa Cruz Fm. \\
\hline & & $\begin{array}{l}\# 5-16.569 \mathrm{Ma}(p) \\
\# 1-16.056 \mathrm{Ma}(p) \\
\# 2-16.139 \mathrm{Ma}(p) \\
\# 4-16.438 \mathrm{Ma}(p) \\
\# 3-16.435 \mathrm{Ma}(p)\end{array}$ \\
\hline
\end{tabular}

$$
\begin{aligned}
& \# 6-16.598 \mathrm{Ma}(\mathrm{p}) \\
& \# 6-16.426 \mathrm{Ma}(\mathrm{h}) \\
& \# 7-17.750 \mathrm{Ma}(\mathrm{p}) \\
& \# 7-17.550 \mathrm{Ma}(\mathrm{h})
\end{aligned}
$$

$\# 8-19.353 \mathrm{Ma}(\mathrm{p})$

\#1-Monte Observación, estaca \#206, TV = 84.56; \#2-Monte Observación, estaca \#64, TV = 82.94; \#3-Monte Observación, estaca \#7, $\mathrm{TV}=82.15$; \#4-Monte León, unit 18 (Bown section), TV = approx 82.50; \#5-Monte León, unit 24 (Bown section), TV = approx. 87.30; \#6-near top of Pinturas Formation, Portezuelo Sumich Norte, $\mathrm{TV}=79.00$; \#7-Estancia El Carmen, beneath mature paleosol sequence (Bown section), TV = 8.00; \#8-Monte León, $3.6 \mathrm{~m}$ beneath erosional unconformity separating Monte León Formation (below) from Santa Cruz Formation (above), Bown section.

Marine rocks of the Grupo Patagónica occur beneath rocks containing an "Astrapothericulense" (="Pinturense") fauna at Karaiken and are also developed beneath uncollected Pinturaslike rocks on a precipitous cliff face at Estancia Videlita, northwest of the town of Gobernador Gregores, and in the centers of broad anticlines along the Río Chalia. These marine rocks record the major westward Patagonian transgression that presumably preceded the advent of the type Santacrucian faunas of the Atlantic coast. They are not present in the type area of the Pinturas Formation, which almost certainly accumulated at higher elevations (in the Andean precordillera), out of reach of marine incursions. Although highly tentative, these stratigraphic relations imply at least a slightly older age for Pinturas deposition than for that of the type Santa Cruz. This relationship obtains because terrestrial Pinturas age sediments almost certainly began to accumulate at Karaiken, Estancia Videlita, and in the area of the middle drainage of the Rio Chalia as soon as the sea was withdrawn from those areas, but while the area of the type Santa Cruz Formation farther east still experienced marine depositional conditions.

The above solution, that the upper part of the Pinturas Formation is slightly older than the base of the Santa Cruz and that the Grupo Patagonica is older than the lower Pinturas, is supported by new radiometric dating of all rocks concerned. Techniques for dating single crystals of plagioclase and biotite were applied to Santacrucian and older tuffaceous materials from Santa Cruz Province by Carl Swisher (Institute of Human Origins, Berkeley, California), with the results shown in Table 3. These data indicate that the upper (but not uppermost) part of the Monte León Formation at Monte León (Grupo Patagónica) is about $19.4 \mathrm{~m}$.y. old. Those rocks lie a few meters beneath an erosional unconformity separating the Monte León Formation from the Santa Cruz Formation (Figures 7, 9). The lower part of the Santa Cruz Formation at Monte León yields dates of about 16.4 Ma and 16.6 Ma, which correspond closely with dates for the lower part of the Santa Cruz Formation at Monte
Observación (about 16.06, 16.14, and 16.44 Ma). Dates obtained on two tuffs from near the base and near the top of the Pinturas Formation (about 17.55-17.75 Ma and 16.43-16.60 Ma, respectively) show that Pinturas rocks are approximately intermediate in age between the Monte León Formation (Grupo Patagónica) and the Santa Cruz Formation. This correlation suggests that, at Monte León and Monte Observación, Pinturas time is contained in the erosional unconformity between the Monte León Formation and the base of the Santa Cruz Formation and that the top of the Pinturas Formation and the base of the coastal Santa Cruz Formation are of approximately the same age. Unfortunately, radiometric date resolution is insufficient to precisely correlate individual tuffaceous units occurring at both Monte León and Monte Observación, units whose relative stratigraphic positions are readily correlated by field observation.

\section{TEMPORAL RECONSTRUCTION}

Sections of the Pinturas Formation (Bown and Larriestra, 1990) and of the Santa Cruz Formation at Monte Observación and Monte León (Figures 7, 9; Tables 2, 3) provide stratigraphic correlation of nearly all of the numerous Santacrucian localities yielding the new specimens of Palaeothentidae discussed in this paper. Although these sections offer an accurate portrayal of palaeothentid occurrences in a detailed stratigraphic context, they do not adequately display the diversity of dental characters of the group in time unless one naively assumes that relative stratigraphic position in meters accurately reflects not only superposition but also relative temporal distribution (that is, relative stratigraphic position is directly proportional to relative depositional [and evolutionary] rate). Relative temporal distribution or, more correctly, apportionate temporal distribution is actually dependent on net sediment accumulation rate (NSAR) and on all factors related to and attendant with this rate. These include rate of deposition (relative positive rate), speed of soil (paleosol) formation (hiatal time = relative neutral rate), speed of erosion (relative negative rate), and lacunal magnitude (all of the above three rates as applied to any rocks removed by erosion).

Determination of NSAR has generally been achieved by geochronologic studies; for example, by radiometric dating or paleomagnetic reversal stratigraphies. However, simple division of meter thicknesses by duration in years (no matter how accurately this duration is known) provides knowledge only of averaged NSAR for the sediment between two temporal data points, e.g., between two radiometric dates, or between points of first records of normal and first records of reversed magnetic polarity. Most commonly, such data points are far apart stratigraphically and provide no information whatsoever for determining the relative NSAR of intervening strata.

Studies of soil (paleosol) pedofacies (Bown and Kraus, 1987; Kraus, 1987) have shown that relative maturities (relative times to form) of paleosols are excellent relative indicators of NSAR at individual floodbasin scales and, in sequences containing the rock records of numerous superposed floodbasins, at formation scales. Soil (paleosol) maturity is indirectly related to NSAR. Therefore, any sequences with superposed paleosols of differing maturities contain a continuous record of relative geologic time (and NSAR) at a resolution equal to the time required to form the thinnest individual paleosols making up the sequence. For example, if one knows the relative maturities of paleosols in a sequence of rock, it can be determined empirically how many paleosols of a given maturity stage are equal in time to a single paleosol of a greater stage of maturity (Bown et al., 1991; Bown and Kraus, in press). 
Solution of the relative maturity for all paleosols in a formation results in a continuous record of proportionate time (and proportionate NSAR) for all parts of the formation. Knowledge of geochronologic age in years for only two data points in the sequence permits the easy conversion of the relative paleosol time just determined to an accurate age estimate in years for any level or interval in the formation. Such a temporally restored sequence, placing all strata, geologic and paleobiotic events, and fossils in their correct positions in time, is termed a restored temporal holostrome (Bown and Larriestra, 1990; Bown et al., 1991).

Using maturation stages determined for paleosols in the Pinturas Formation, Bown and Larriestra (1990, p. 113-115, fig. 12) constructed the restored temporal holostrome for the Miocene Pinturas Formation, from which come many of the palaeothentids discussed in this work. Using data from the same type of paleosols present throughout the Santa Cruz Formation at Monte Observación and Monte León, the restored temporal holostrome of the Santa Cruz Formation was also reconstructed, placing the bulk of new fossil vertebrate localities discussed herein in their proper relative temporal perspective (Table 2). Temporal holostrome reconstruction is important paleobiologically because it is the key to evaluating evolutionary rates which, in turn, are central to determination of the nature and tempo of evolutionary change that has taken place (Bown and Anderson, manuscript). It is also the critical factor in linking evolutionary change to sediment production and, hence, tectonics. Palaeothentid evolution viewed against temporally restored Colhuéhuapian-Santacrucian sequences is discussed at the end of this paper. A full account of the technique of temporal holostrome reconstruction was presented by Bown and Kraus (in press).

\section{SYSTEMATIC PALEONTOLOGY}

Superorder MARSUPIALIA Illiger, 1811

Order PaucituberCulata Ameghino, 1894

Family PALAEOTHENTIDAE

(Sinclair, 1906) Osgood, 1921

Type genus. - Palaeothentes Ameghino, 1887, p. 5.

Emended diagnosis. - Differs from Caenolestidae in: 1) lack of antorbital vacuity; 2) deeper and relatively shorter mandibular ramus; 3) loss of one upper and one or two lower incisors; 4) p2 small to minute; 5) $\mathrm{m} 1$ with more elongate paracristid; 6) $\mathrm{M} 1 / \mathrm{m} 1$ invariably much larger than $\mathrm{M} 2 / \mathrm{m} 2$ and molars decrease in size posteriorly; 7) $\mathrm{m} 1$ cristid obliqua joins protocristid at metaconid or terminates at equivalent lingual position (posterior to metaconid), but with no connection; 8) P1-2 very reduced; 9) P3 enormous; 10) M1 with elevated hypocone platform (unworn teeth), invariably separated from trigon at lingual midline of tooth by a deep fissure. Differs from Abderitidae in having: 1) a shallower mandibular ramus; 2) $\mathrm{m} 1$ with a prominent metaconid; 3) a not overly compressed or elevated $\mathrm{m} 1$ trigonid, nor a bladelike, shearing trigonid with a serrated crest; 4) $\mathrm{m} 2-3$ commonly with paraconid in generalized species; 5 ) less rectangular $\mathrm{m} 2-4$; 6) M1-3 tribosphenic, unsquared, and divided into distinct elevated hypocone platform and lower trigon basin; 7) M1-3 lacking lophs connecting primary labial and lingual cusps.

Included taxa. - Subfamily Acdestinae n. subfam.; subfamily Palaeothentinae Sinclair, 1906 (Osgood, 1921); genus Hondathentes incertae sedis Dumont and Bown, in press.

Distribution.-Deseadan (later Oligocene) through Santacrucian (Miocene) of Argentina; Deseadan of Bolivia; Santacrucian of Chile; late Santacrucian (or younger) of Colombia (Hondathentes only).
Subfamily ACDESTINAE n. subfam.

Type genus. - Acdestis Ameghino, 1887, p. 5.

Diagnosis. - Acdestinae differ from Palaeothentinae in having: 1) a foreshortened ramus; 2) reduced, sometimes absent $\mathrm{p} 2$; 3) reduced, small to minute, commonly single-rooted p 3 that is invariably half or less as tall as $\mathrm{m} 1$ paraconid; 4) p3 lacks anterobasal cusp; 5) cusps of first three lower molars commonly more internally (less peripherally) dispersed; 6) $\mathrm{ml}$ lacking a twinned paraconid; 7) $\mathrm{ml}$ protoconid and paraconid of about equal height (in unworn specimens); 8) $\mathrm{m} 1$ with relatively longer paracristid; 9) lack of pronounced vespiform constriction between trigonid and talonid of $\mathrm{m} 2$ and $\mathrm{m} 3$; 10) more triangular $\mathrm{M} 2-4$; and 11) more reduced $\mathrm{M} 4 / \mathrm{m} 4$, generally lacking distinct cusps.

Included genera. - The type genus; Acdestoides n. gen.; Acdestodon n. gen., and Trelewthentes n. gen.

Distribution. - Deseadan (later Oligocene) through Santacrucian (Miocene) of Argentina.

\section{Genus ACDESTOIDES n. gen.}

Callomenus LoOMIS, 1914, p. 223.

Acdestis Pascual and Odreman Rivas, 1971, p. 383; Clemens and

MARSHALl, 1976, p. 69; MARSHALl, 1980, p. 92.

Palaeothentes PATTERSON AND MARShall, 1978, p. 87.

Type species. - Acdestoides praecursor (Loomis, 1914); only known species.

Etymology.-Greek -eides (suff.), like, akin to; in allusion to similarities to Acdestis.

Diagnosis. - Largest acdestine. In contrast to $\mathrm{m} 2$ in Acdestodon, $\mathrm{m} 2$ in Acdestoides has a small paraconid, an anterolabially-posterolingually (not transversely) oriented protocristid, a larger length : width ratio, a longer entocristid, and a deeper hypoflexid. In contrast with Trelewthentes, $\mathrm{m} 2$ of Acdestoides has a greater L/W ratio, a much longer entocristid (closing talonid basin on lingual side), a deeper hypoflexid, and an anterolabially-posterolingually (not anterolingually-posterolabially) directed postvallid. In contrast with Acdestis, m2 of Acdestoides possesses a greater $\mathrm{L} / \mathrm{W}$ ratio, a slightly longer entocristid, a deeper hypoflexid, and a posterolingually-anterolabially (not linguolabially) oriented postvallid. As in Trelewthentes, $\mathrm{m} 2$ metaconid lacks mure on its anterior side, in contrast to condition in Acdestis.

\section{ACDESTOIDES PRAECURSOR (Loomis, 1914)}

Callomenus praecursor LoOMIs, 1914, p. 223.

Acdestis praecursor (Loomis). PASCUAL AND OdREMAN Rivas, 1971, p.

373; Clemens and Marshall, 1976, p. 69; Marshall, 1980, p. 92. Palaeothentes praecursor (Loomis). PATTERSON AND MARSHALL, 1978, p. 87.

Holotype. - AC 3020, fragment of right ramus with $\mathrm{m} 2$ (Patterson and Marshall, 1978, fig. 21; Marshall, 1980, fig. 31); only known specimen.

Diagnosis. - Only known species; as for genus. Measurements in Table 7.

Distribution.-Deseadan (later Oligocene) rocks at Cabeza Blanca, coastal Provincia del Chubut, Argentina.

Discussion. - Pascual and Odreman Rivas (1971) and Clemens and Marshall (1976) transferred Loomis' Callomenus praecursor to genus Acdestis Ameghino, the type of Callomenus ( $C$. intervalatus) being a junior synonym of Acdestis oweni Ameghino. This assessment was briefly abandoned by Patterson and Marshall (1978) but was reinstated by Marshall (1980).

The type and only known specimen of Acdestoides praecursor is a right ramal fragment with $\mathrm{m} 2$, the third premolar and $\mathrm{m} 1$ having been lost subsequent to its description by Loomis. Even 

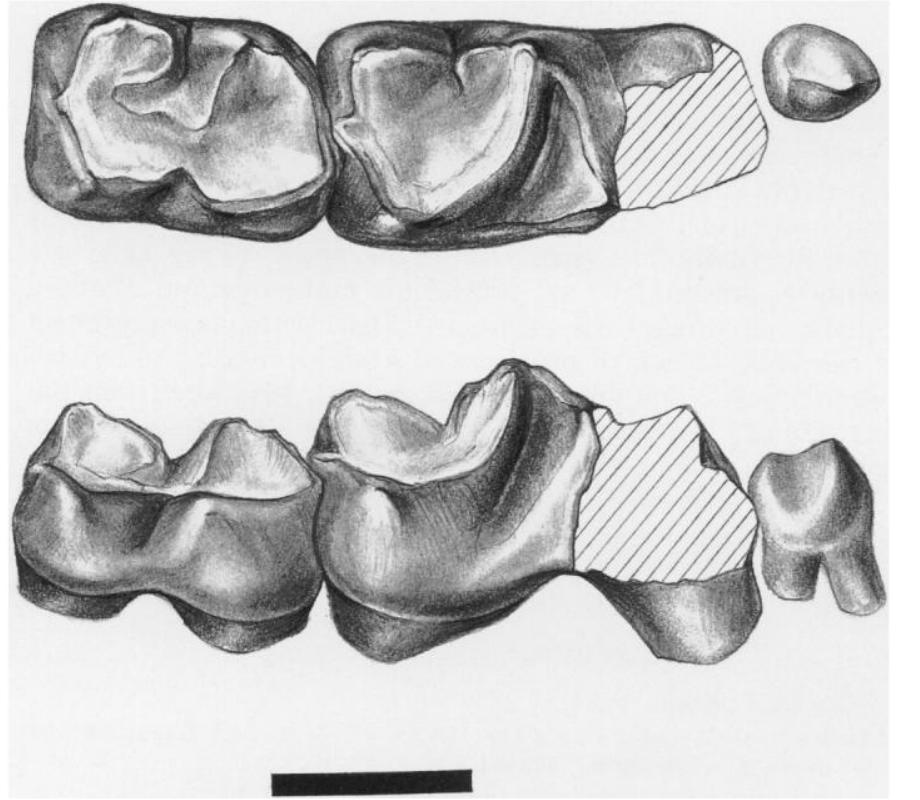

FIGURE 10-Acdestodon bonapartei, n. gen. and sp. (Acdestinae); MACN CH-1311 (holotype), right p3-m2, in occlusal (top) and labial (bottom) aspects (bar $=2.0 \mathrm{~mm}$ ).

so, the distinctive morphology of $\mathrm{m} 2$ is sufficient to diagnose the new genus from Acdestodon, Acdestis, and Trelewthentes. Comparing Loomis' (1914, figs. 147 and 148) illustrations with what remains of the type specimen suggests that his figures are unreliable for reconstructing the morphology of $\mathrm{ml}$ ( $\mathrm{p} 4$ of Loomis), even though (together with preserved roots in the type) they demonstrate $\mathrm{p} 3$ to have been exceedingly small, short, and double-rooted.

Acdestoides praecursor was a medium to large palaeothentid and the largest of the Acdestinae. The mandible is deep beneath the first molar and p3 was small and double-rooted as in Acdestis oweni, not minute and/or single-rooted as in many Acdestis lemairei $\mathrm{n}$. sp. If Loomis' (1914, fig. 147) illustration of $\mathrm{m} 1$ is at all accurate, that tooth in Acdestoides praecursor lacks a bifurcated and fissured paraconid and therefore resembles acdestine and not palaeothentine palaeothentids. His rendition of $\mathrm{m} 2$, however, bears little resemblance to that tooth in the type specimen (see Patterson and Marshall, 1978, fig. 21).

Of conservative morphology in the Palaeothentinae, $\mathrm{m} 2$ is very distinctive in each acdestine genus and is alone adequate to diagnose the four included genera. In Acdestoides, $\mathrm{m} 2$ is larger and relatively narrower than in either Trelewthentes or Acdestis and a low entocristid joins the entoconid with the back of the metaconid, closing the talonid basin lingually. In contrast to Acdestodon, Acdestoides possesses a paraconid on m2, lacks a transverse $\mathrm{m} 2$ protocristid, and has a larger $\mathrm{m} 2$ length : width ratio, a longer $\mathrm{m} 2$ entocristid, and a deeper $\mathrm{m} 2$ hypoflexid. The talonid basin is lingually open in both Trelewthentes and $A C$ destis. In the former genus, the entocristid is restricted to a tiny anterolingually directed spur on the anterior side of the entoconid, whereas in Acdestis the entocristid is extended more anteriorly but is separated from the metaconid by a deep fissure not present in Acdestoides.

The three genera also differ significantly in the orientation of the postvallid surface (protocristid) and in the configuration of the cristid obliqua. In Acdestoides, the hypoflexid is deep and the cristid obliqua joins the anterolabially-posterolingually aligned postvallid about at its midline. In Trelewthentes and
Acdestis, the hypoflexid is considerably shallower and joins the postvallid far to its labial side. In Acdestis, the postvallid is straight (linguolabial) in orientation, whereas it is anterolingually-posterolabially oriented in Trelewthentes. Finally, the trigonid basins in Acdestoides and Trelewthentes are open anterolingually, not closed by a raised mure as in Acdestis.

The close correspondence of molar morphologies in Palaeothentes and Pilchenia on the one hand and Acdestis, Acdestoides, and Trelewthentes on the other argues for recognition of two palaeothentid subfamilies. This arrangement is also supported by the much smaller p3 in the Acdestinae. See Figure 29 for $\mathrm{m} 2$ area of Acdestoides praecursor with respect to distributions of $\mathrm{m} 2$ area for other Deseadan-Santacrucian Palaeothentidae.

Genus ACDESTOdON n. gen.

Type species. - Acdestodon bonapartei $\mathrm{n}$. sp. and only known species.

Etymology.-Acdestis and Gr. -odontos, tooth; the closest similarity of the new genus and species is to the Santacrucian genus Acdestis.

Diagnosis. - Acdestodon differs from Acdestoides in lacking a paraconid on $\mathrm{m} 2$ and in having a transverse $\mathrm{m} 2$ protocristid, a smaller $\mathrm{m} 2$ length : width ratio, a shorter $\mathrm{m} 2$ entocristid, and a shallower $\mathrm{m} 2$ hypoflexid. From Trelewthentes, Acdestodon differs in having: 1) $\mathrm{ml}$ with type 4 trigonid structure; 2) $\mathrm{m} 1$ with a much more transverse protocristid; 3) $\mathrm{m} 2$ with a longer entocristid; 4) $\mathrm{m} 2$ with a more strongly developed protocristid; 5) $\mathrm{m} 2$ with a more transverse protocristid; and 6) $\mathrm{m} 2$ lacking paraconid. Acdestodon differs from Acdestis in having: 1) $\mathrm{ml}$ with type 4 trigonid structure; 2) a bent cristid obliqua on $\mathrm{m} 1$; 3 ) a longer entocristid on $\mathrm{m} 1$; and 4) a relatively shorter, more transverse $\mathrm{ml}$ paracristid.

\section{ACDESTODON BONAPARTEI $\mathbf{n}$. sp.}

Figures 10, 15.1

Holotype. - MACN CH-1311, right p3-m2 (Figure 10).

Diagnosis. - Only known species; as for genus. Measurements in Table 7.

Hypodigm. - The type specimen and MACN CH-1472, right ml (Figure 15.1).

Distribution. - Deseadan (later Oligocene) rocks at Cabeza Blanca, southeast Provincia del Chubut, and Colhuéhuapian (latest Oligocene or earliest Miocene) part of Sarmiento Formation at Sacanana, Pampa de Gan Gan, north-central Provincia del Chubut (Rusconi, 1935; Fleagle and Bown, 1983).

Etymology. - For José F. Bonaparte, in recognition of his profound achievements in Argentine paleontology and in recognition of his generous assistance to this research.

Discussion. - With the probable exception of Acdestodon, acdestine $\mathrm{ml}$ 's possess a longer paracristid than palaeothentines and the lower first molar is more conservative in that it lacks the twinned paraconid seen in all palaeothentines. Palaeothentid $\mathrm{m} 1$ trigonid morphology is divisible into four varieties based on the orientation of the protocristid and the nature of its confluence with the metaconid. These are here designated types 1 , 2,3 , and 4 and are distinguished as follows: type 1, protocristid oriented more-or-less transversely (linguolabially) and with metaconid having anteriorly directed spur that connects it directly to lingual margin of protocristid, metaconid untwinned (Figure 11.1); type 2, protocristid oriented more anterolabiallyposterolingually and directly confluent with anterolabial base of untwinned metaconid (Figure 11.2); type 3, protocristid oriented very anterolabially-posterolingually, lacking spur, and separated from metaconid by a deep fissure (Figure 11.3); and type 4, protocristid oriented transversely (labiolingually) and joined directly (no fissure) to anterior moiety of twinned metaconid- 


\section{lingual}

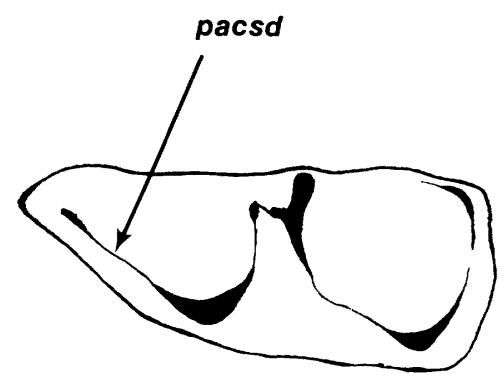

TYPE 1 (little worn)

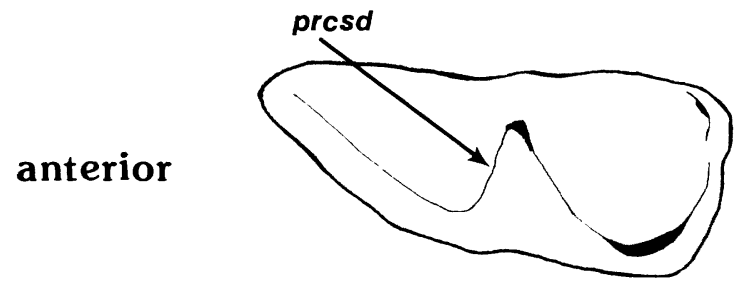

TYPE 2 (little worn)

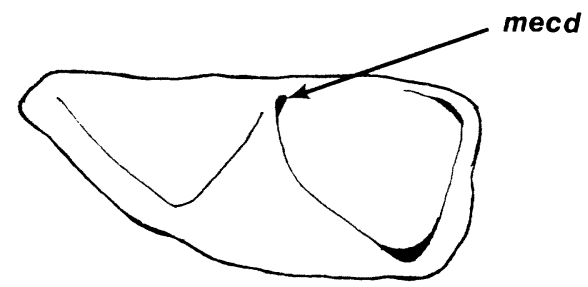

TYPE 3

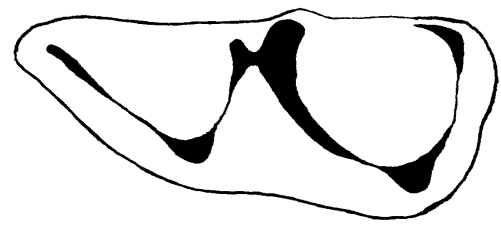

TYPE 1 (worn)

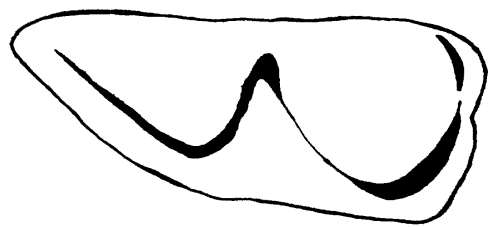

posterior

TYPE 2 (worn)

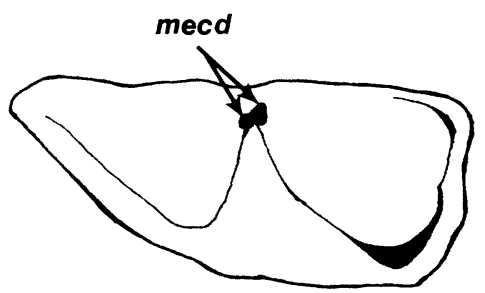

TYPE 4

\section{labial}

FIGURE $11-$ Variability in $\mathrm{m} 1$ trigonid structure in the Palaeothentidae (see text for discussion of morphology). mecd = metaconid; pacsd = paracristid; prcsd = protocristid. All examples drawn to same scale.

posterior moiety of metaconid lacking anterior spur (Figure 11.4). Although the distribution of trigonid type is variable in Acdestinae (for example, Acdestis oweni variably possesses types 13 ), each type is by far most abundantly identified with a particular acdestine genus, of which Acdestodon is the sole acdestine genus with trigonid type 4 (also present in the palaeothentine Pilchenia lucina).

With the transferral of Loomis' (1914) Callomenus praecursor from genus Acdestis (where it had been placed by Marshall, 1980) to the new genus Acdestoides, no taxa remain as preSantacrucian records of Acdestis. Deseadan and Colhuéhuapian Acdestodon, though most closely related to Acdestis, differs from Santacrucian $A$. oweni and $A$. lemairei in several aspects of dental morphology, the most important of which include possession of stage $4 \mathrm{ml}$ trigonid structure (Figure 11), a shorter $\mathrm{ml}$ paracristid, an $\mathrm{ml}$ entocristid that is more anteriorly attenuated, and retention of a paraconid on $\mathrm{m} 2$. The $\mathrm{m} 1$ paracristid, though estimated from the relative positions of the protoconid and basolingual paraconid swelling on damaged teeth, was almost certainly shorter than in Acdestis and this short condition is unquestionably a primitive character for Palaeothentidae. The retention of a paraconid on $\mathrm{m} 2$ is doubtlessly also a residual generalized feature retained from the earliest antecedants of the family, and is also present in the early acdestine Trelewthentes and in the Deseadan palaeothentine Pilchenia lucina. Hondathentes cazador (the most generalized known palaeothentid) also possesses closed lingual talonids on $\mathrm{m} 1$ and $\mathrm{m} 2$. The tooth sizes and ramal depth of Acdestodon are within the range of dimensions for Acdestis oweni and are much larger than in $A$. lemairei.

Unfortunately, the paraconid region of $\mathrm{m} 1$ is broken and $\mathrm{m} 3$ is unknown. As these are two very important teeth for diagnosing acdestines, further resolution of the phyletic position of Acdestodon bonapartei with respect to Acdestis must await additional material. See Figures 28 and 29 for molar areas of Acdestodon bonapartei with respect to molar area distributions in other Deseadan-Santacrucian Palaeothentidae.

\section{Genus Trelewthentes n. gen.}

Type species. - Trelewthentes rothi $\mathrm{n}$. sp.; only known species.

Etymology. - For the city of Trelew, Provincia del Chubut, an originally Welsh settlement situated near the locality of the type species. 
TABLE 4-Specimen data for first three molars, $\mathrm{m} 1$ trigonid structure, and ramal depth in Trelewthentes rothi $\mathrm{n}$. gen. and sp. from La Cantera in the Sarmiento Formation, Provincia del Chubut. $\ln =$ natural logarithm $(\mathrm{L} \times \mathrm{W})$ of molar; MT $=\mathrm{m} 1$ trigonid structure (type 1 through type $4-$ see text); DRml = depth of ramus beneath $\mathrm{ml}$ on lingual side; $\mathrm{x}=$ broken tooth. Measurements in millimeters.

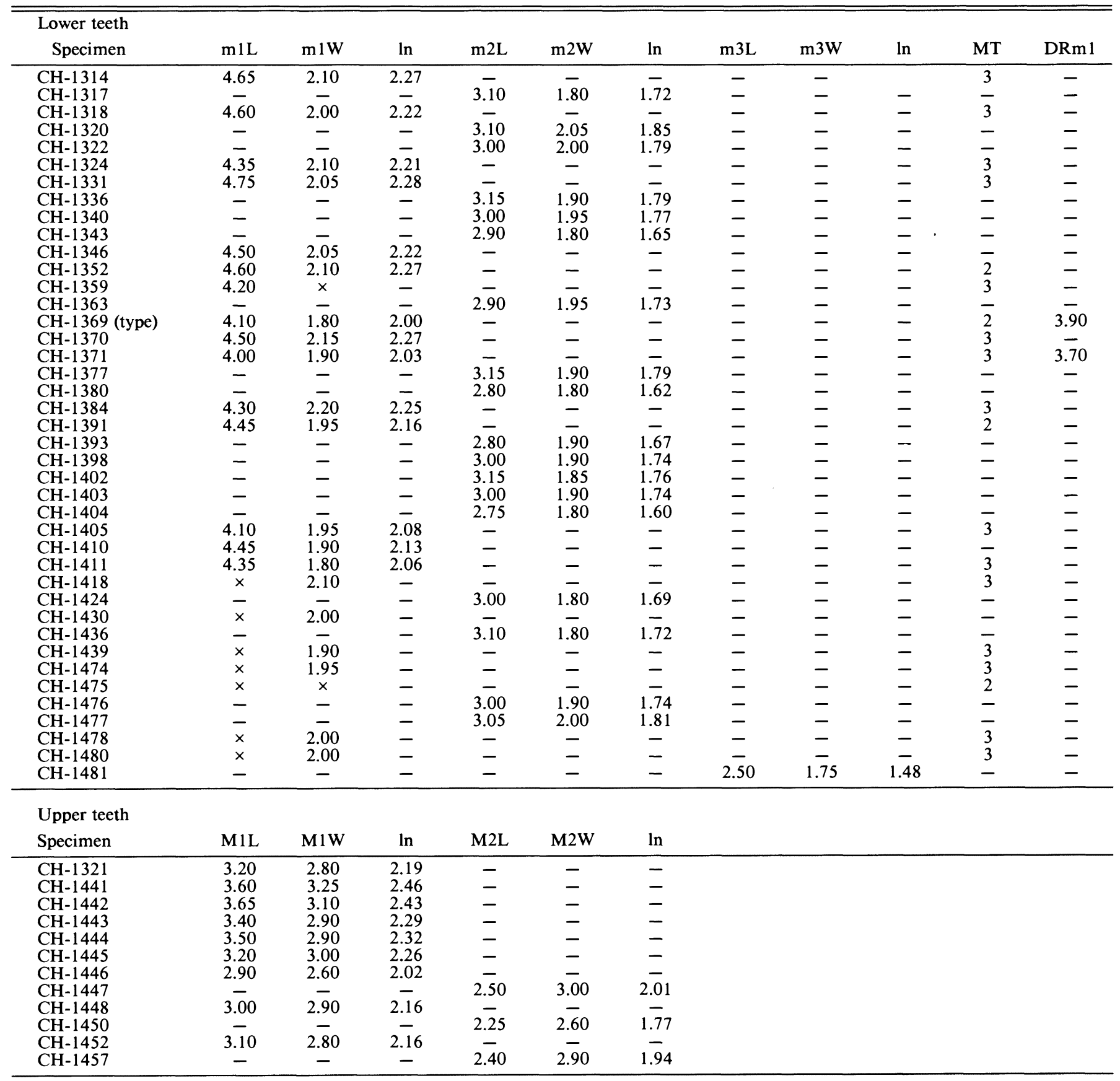

Diagnosis. - From Acdestoides, Trelewthentes differs in having: 1) $\mathrm{m} 2$ with a smaller L/W ratio; 2) a shallower hypoflexid that meets the postvallid more labially; 3 ) a lingually open talonid; and 4) a postvallid (protocristid) that is oriented anterolingually-posterolabially. From Acdestodon, Trelewthentes differs in having: 1) types 3 and $2 \mathrm{ml}$ trigonid structure; 2) a less transverse (more anterolabially-posterolingually) oriented protocristid; 3 ) a discrete $\mathrm{m} 2$ paraconid; 4) a shorter $\mathrm{m} 2$ entocristid; 5) a very weakly developed to lacking $\mathrm{m} 2$ protocristid; and 6 ) an anterolingually-posterolabially oriented $\mathrm{m} 2$ protocristid (when present). Trelewthentes differs from Acdestis in having: 1) an $\mathrm{ml}$ trigonid in which the metaconid is separated from the protocristid by a fissure (type 3 trigonid structure, see text); 2) a less transverse (more anterolabially-posterolingual) $\mathrm{ml}$ protocristid; 3) the largest $\mathrm{m} 3 / \mathrm{m} 2$ area ratio of any palaeothentid (it is the smallest in Acdestis); 4) a more cuspidate (less trenchant) $\mathrm{m} 2$ paraconid; 5) a more cuspidate (less trenchant) $\mathrm{m} 2$ entoconid; 6) an $\mathrm{m} 2$ trigonid open on the anterolingual side; 7) an $\mathrm{m} 2$ talonid that is open lingually; 8 ) an $\mathrm{m} 2$ postvallid oriented anterolingually-posterolabially; 9) $\mathrm{m} 3 / \mathrm{m} 2$ area exceeding 0.69 ; 
10) M1 protocone and hypocone more widely splayed and separated by a deep valley; and 11) M1 lacking a stylar shelf.

\section{TRELEWTHENTES ROTHI $\mathrm{n}$. $\mathrm{sp}$}

Figures 12, 15.2, 15.3

Holotype. - MACN CH-1369, right p3-ml (Figure 12).

Diagnosis. -Only known species; as for genus. Measurements in Table 4.

Hypodigm. - The type specimen and the following MACN specimens: $\mathrm{CH}-1314$, right $\mathrm{ml}$; $\mathrm{CH}-1317$, left $\mathrm{m} 2$; $\mathrm{CH}-1318$, left $\mathrm{ml}$; $\mathrm{CH}-1320$, right $\mathrm{m} 2$; $\mathrm{CH}-1321$, left $\mathrm{Ml} ; \mathrm{CH}-1322$, right $\mathrm{m} 2$; $\mathrm{CH}-1324$, right $\mathrm{ml}$; $\mathrm{CH}-1331$, right $\mathrm{ml}$; $\mathrm{CH}-1336$, right $\mathrm{m} 2$ (Figure 12); $\mathrm{CH}-1340$, right $\mathrm{m} 2 ; \mathrm{CH}-1343$, left $\mathrm{m} 2 ; \mathrm{CH}-$ 1346, left m l; CH-1352, left m l; $\mathrm{CH}-1359$, left ml; $\mathrm{CH}-1363$, left m2; CH-1370, left ml; CH-1371, left p3-ml; CH-1377, right $\mathrm{m} 2 ; \mathrm{CH}-1380$, left $\mathrm{m} 2 ; \mathrm{CH}-1384$, left $\mathrm{ml} ; \mathrm{CH}-1391$, right $\mathrm{ml}$; CH-1393, left m2; CH-1398, left m2; CH-1402, left m2; $\mathrm{CH}-1403$, left m2; $\mathrm{CH}-1404$, right $\mathrm{m} 2 ; \mathrm{CH}-1405$, left $\mathrm{ml} ; \mathrm{CH}-$ 1410, right $\mathrm{ml} ; \mathrm{CH}-1411$, right $\mathrm{ml} ; \mathrm{CH}-1418$, left $\mathrm{ml} ; \mathrm{CH}-$ 1424, right $\mathrm{m} 2$; $\mathrm{CH}-1430$, right $\mathrm{ml} ; \mathrm{CH}-1436$, left $\mathrm{m} 2$; $\mathrm{CH}-$ 1439, left $\mathrm{m} \mathrm{I}$; $\mathrm{CH}-1441$, right Ml (Figure 15.2); $\mathrm{CH}-1442$, right $\mathrm{Ml}$; $\mathrm{CH}-1443$, right $\mathrm{Ml}$; $\mathrm{CH}-1444$, right $\mathrm{Ml}$; $\mathrm{CH}-1445$, right M1; CH-1446, left $\mathrm{M} 2$; $\mathrm{CH}-1447$, right $\mathrm{M} 2$; $\mathrm{CH}-1448$, right $\mathrm{M} 1 ; \mathrm{CH}-1450$, right $\mathrm{M} 2$; $\mathrm{CH}-1452$, right $\mathrm{M} 1 ; \mathrm{CH}-1457$, left M2; CH-1474, left m l; CH-1475, right m 1; CH-1476, left m2; $\mathrm{CH}-1477$, left $\mathrm{m} 2 ; \mathrm{C}-1478$, right $\mathrm{ml} ; \mathrm{CH}-1480$, right $\mathrm{ml}$; $\mathrm{CH}-$ 1481, left $\mathrm{m} 3$ (Figure 15.3).

Distribution. - All specimens are from La Cantera in the upper part of the Colhuéhuapian (latest Oligocene or earliest Miocene) Trelew Member of the Sarmiento Formation; valley of the Río Chubut, near Gaiman, eastern part of Provincia del Chubut, Argentina (Fleagle and Bown, 1983).

Etymology. - For Santiago Roth, turn of the century geologist, paleontologist, and explorer, in recognition of his early work in the Trelew area.

Discussion. - The new genus and species Trelewthentes rothi is a third important addition to the acdestine palaeothentids, one which underscores their previously unrecognized generic diversity and provides (with Acdestodon bonapartel) one of the two new and only known Colhuéhuapian records of the subfamily. Trelewthentes is additionally significant because, in contrast to Acdestoides praecursor and Acdestodon bonapartei, it is known from 54 specimens providing composite examples of $\mathrm{p} 3$, $\mathrm{m} 1, \mathrm{~m} 2, \mathrm{~m} 3, \mathrm{M} 1$, and $\mathrm{M} 2$. Trelewthentes rothi is a small acdestine with teeth only slightly larger than those of the new Santacrucian species Acdestis lemairei. Trelewthentes clearly differs from Acdestoides, Acdestodon, and Acdestis in its distinctive molar morphology, especially that of $\mathrm{m} 2$ (see Discussion section under Acdestoides praecursor).

Trelewthentes rothi $\mathrm{ml}$ 's are dominated by type 3 trigonid structure (15 examples, and four examples of type 2), and this genus and species is additionally distinguished from Acdestis on this character, for which trigonid types 1 and $2(A$.oweni) and type 2 ( $A$. lemairei) are prevalent. An excellent unworn example of type 3 trigonid structure in Trelewthentes rothi is $\mathrm{CH}-1318$ (Figure 11.3), and $\mathrm{CH}-1369$ (the type specimen, Figure 12) is a worn example.

Trelewthentes rothi evinces the most derived $\mathrm{m} 2$ morphology seen in Acdestinae. Assuming a more or less transverse (linguolabial) $\mathrm{m} 2$ postvallid orientation to be generalized for the Palaeothentidae (seen in most Didelphidae and Caenolestidae and the condition typical of Acdestis, Acdestodon, and Palaeothentinae), that of Trelewthentes is divergent and unique in its sharp anterolingual-posterolabial configuration. In Deseadan Acdestoides, the orientation of the postvallid is, conversely, anterolabial-posterolingual. The $\mathrm{m} 2$ trigonid in $T$. rothi is also
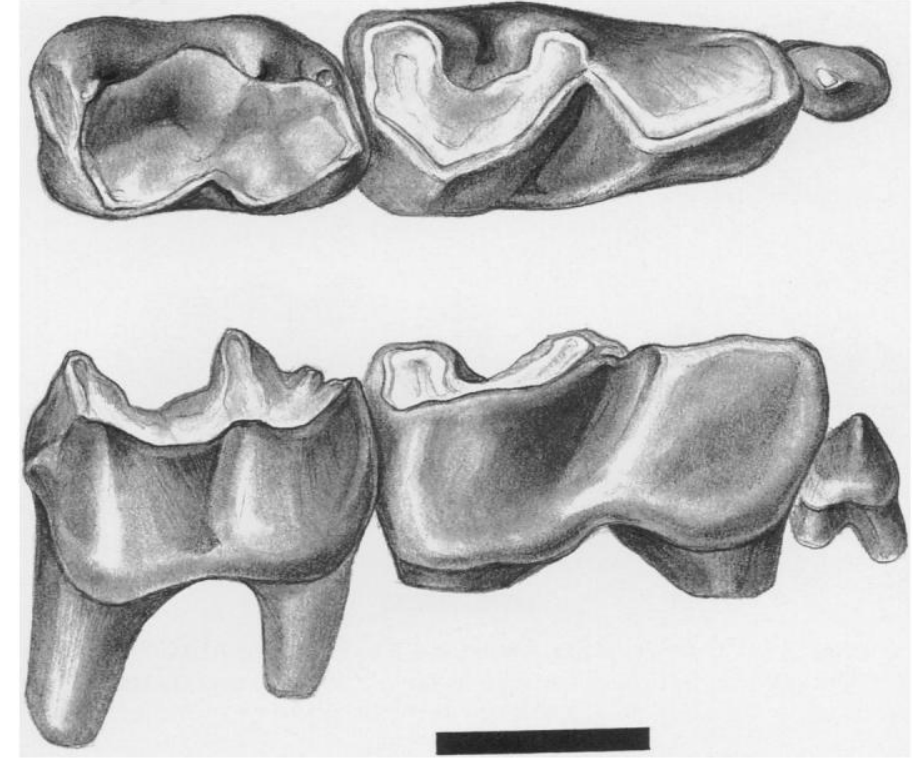

FIGURE $12-$ Trelewthentes rothi $\mathrm{n}$. gen. and sp. (Acdestinae); composite of MACN CH-1369 (type), right p3-m1, and MACN CH-1336, right $\mathrm{m} 2$, in occlusal (top) and labial (bottom) aspects (bar $=2.0 \mathrm{~mm}$ ).

open anterolingually and the trigonid and talonid basins are essentially confluent (low to absent protocristid). All three of these features are derived with respect to most caenolestoids. The very large $\mathrm{m} 3$ area with respect to $\mathrm{m} 2$ area in Trelewthentes $(\mathrm{m} 3 \mathrm{area} / \mathrm{m} 2$ area: $\mathrm{OR}=0.72-0.88, \bar{x}=0.83, \mathrm{~N}=18)$ is a generalized feature for palaeothentids, acdestines especially, and those proportions (obtained by matching the lone $\mathrm{m} 3$ specimen with each of 18 specimens of $\mathrm{m} 2$ ) are considerably greater than in either Acdestis oweni $(\mathrm{m} 3 \mathrm{area} / \mathrm{m} 2$ area: $\mathrm{OR}=0.40-0.63, \bar{x}$ $=0.50, \mathrm{~N}=44)$ or $A$. lemairei $(\mathrm{m} 3$ area $/ \mathrm{m} 2$ area: $\mathrm{OR}=0.39$ $0.56, \bar{x}=0.46, \mathrm{~N}=11$ ) and, indeed, are the greatest in the Palaeothentidae.

Trelewthentes rothi, then, is an early acdestine with dental specializations that are largely more advanced than those of geologically younger Acdestis, and which are divergently specialized away from the earlier acdestine Acdestoides and the both earlier and approximately coeval Acdestodon bonapartei from Deseadan rocks at Cabeza Blanca and Colhuéhuapian rocks at Sacanana.

Trelewthentes rothi was a medium-sized probably herbivorous palaeothentid (Strait et al., 1990, and unpublished data). See Figures 28-31 for molar area distributions of Trelewthentes rothi with respect to those of other Deseadan-Santacrucian $\mathrm{Pa}$ leothentidae.

\section{Genus ACDESTIS Ameghino, 1887}

Acdestis Ameghino, 1887, p. 5.

Dipilus AMEghINo, 1890, p. 153.

Decastis AMeghino, 1891, p. 305.

Callomenus AMEghino, 1891, p. 306 (partim).

Type species. - Acdestis oweni Ameghino, 1887, p. 5.

Included species. - The type species and $A$. lemairei $\mathrm{n}$. sp.

Distribution. - Santacrucian (early to middle Miocene) Pinturas and Santa Cruz Formations, Provincia de Santa Cruz, Argentina (Santacrucian temporal unit values $=56.8-96.2$ ).

Revised diagnosis. - Acdestis is a medium-large acdestine that differs from Acdestoides in having: 1) an $\mathrm{m} 2$ with a smaller $\mathrm{L} / \mathrm{W}$ ratio; 2 ) a shallower $m 2$ hypoflexid that meets the postvallid 

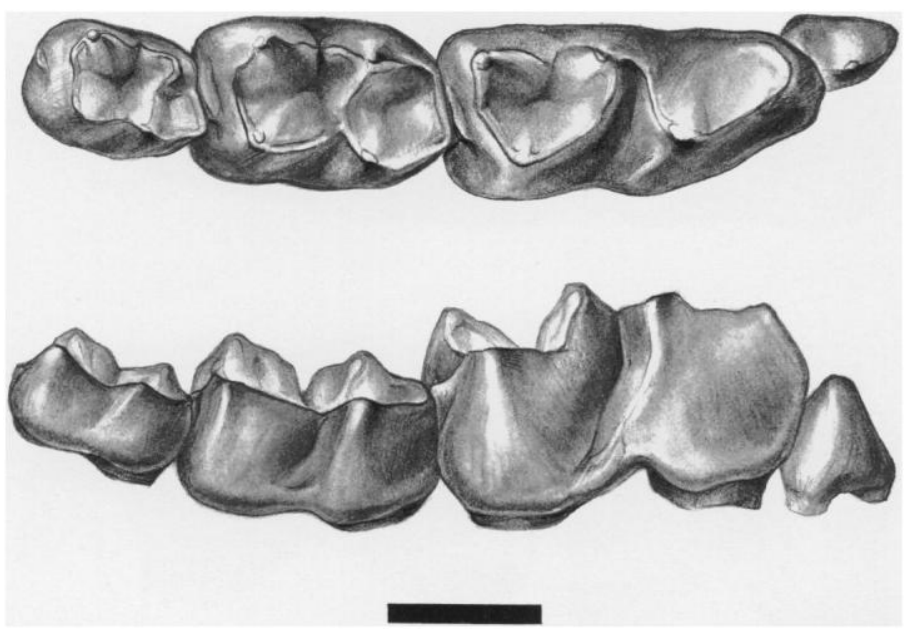

Figure 13-Acdestis oweni Ameghino (Acdestinae); MACN SC-972, right p3-m3, in occlusal (top) and labial (bottom) aspects (bar $=2.0$ $\mathrm{mm})$.

more labially; 3 ) an $\mathrm{m} 2$ talonid that is more open on the lingual side; and 4) an $\mathrm{m} 2$ postvallid (protocristid) that is oriented more linguolabially. From Acdestodon, Acdestis differs in having: 1) $\mathrm{m} 1$ trigonid types 1 and 2 prevalent with no examples of type 4 ; 2) $\mathrm{ml}$ with a straight cristid obliqua; 3) $\mathrm{ml}$ with a shorter entocristid; and 4) $\mathrm{m} 1$ and $\mathrm{m} 2$ with more internally dispersed cusps. Acdestis differs from Trelewthentes in having: 1) a higher proportion of $\mathrm{ml}$ in which the metaconid is directly connected to the protocristid (trigonid types 1 and 2 are dominant); 2) a more transverse $\mathrm{m} 1$ protocristid; 3 ) a less cuspidate (more trenchant) $\mathrm{m} 2$ paraconid; 4) a less cuspidate (more trenchant) $\mathrm{m} 2$ entoconid; 5) an anterolingually closed $\mathrm{m} 2$ trigonid; 6) an $\mathrm{m} 2$ talonid that is partially closed by the entocristid on the lingual side; 7) an $\mathrm{m} 2$ postvallid that is oriented linguolabially (not anterolingually-posterolabially); 8) a much more profound size gradient from $\mathrm{m} 1$ through $\mathrm{m} 4$, with $\mathrm{M} 3 / \mathrm{m} 3$ area markedly smaller than $\mathrm{M} 2 / \mathrm{m} 2$ area (even more so than in the palaeothentine Palaeothentes aratae); 9) M1 protocone and hypocone less widely splayed and not separated by a deep valley; and 10) a small stylar shelf on M1.

\section{ACDESTIS OWENI Ameghino, 1887}

Figures 13, 15.4

Acdestis oweni Ameghino, 1887, p. 5.

Dipilus rurigenus Clemens AND MARSHALl, 1976, p. 71.

Dipilus spectans Clemens AND MARShall, 1976, p. 71.

(See Marshall, 1980, p. 93 for complete listing.)

Holotype.-MACN 1379, right mandibular ramus with p3$\mathrm{m} 1, \mathrm{~m} 2$ (trigonid), m3-4.

Revised diagnosis. - Ramal depth beneath $\mathrm{m} 1$ on lingual side equal to or greater than $4.0 \mathrm{~mm}(4.0-6.0 \mathrm{~mm})$, deeper than in A. lemairei. Lower third premolar double-rooted, generally erect, small to minute, but of moderate height; taller than in $A$. lemairei, and fused roots rare. Lower molars larger than in $A$. lemairei or at extreme upper end of size range in latter species. Lower first molar with type 1 trigonid structure (see Discussion of Acdestodon bonapartei) most common. Mean of proportion of $\mathrm{m} 3$ area to $\mathrm{m} 2$ area $=0.50(\mathrm{~N}=44)$, greater than in $A$. lemairei $(0.46)$. M4/m4 very reduced but generally less so than in $A$. lemairei. See Table 5 for measurements.

Hypodigm. - The type specimen, specimens listed in Marshall (1980, p. 94-96, 99-101, excepting MACN 5562), and the new material listed below.
New material. -MACN numbers SC-407, left m 1-2; SC-408, left $\mathrm{m} 2-3$ (damaged); SC-416, left $\mathrm{m} 2-4$; SC-451, right $\mathrm{m} 2-3$; $\mathrm{SC}-476$, left $\mathrm{m} 2$ (damaged); SC-500, right $\mathrm{m} 2$; SC-538, left $\mathrm{m} 2$; SC-558, left m2-3; SC-578, right p3-m3; SC-585, left m2; SC603, right $\mathrm{m} \mathrm{1}$; SC-641, left p3 (part), m 1-2; SC-643, right $\mathrm{ml}$; SC-644, left m2; SC-659, left m2; SC-680, left m2-4; SC-682, right p3-m1; SC-709, right $\mathrm{m} 2-3$; SC-731, right $\mathrm{p} 3-\mathrm{m} 2$; SC874, right $\mathrm{m} 3-4$; SC-896, left $\mathrm{m} 2$; SC-972, right $\mathrm{p} 3-\mathrm{m} 3$ (Figure 13); SC-988, left $\mathrm{m} 1$ (talonid), $\mathrm{m} 2, \mathrm{~m} 3$ (trigonid); SC-989B, right $\mathrm{m} 1$; SC-990, right $\mathrm{m} 1$; SC-991, left $\mathrm{ml-2}$; SC-1008, right $\mathrm{m} 2-$ 3; SC-1011, right $\mathrm{m} 2$; $\mathrm{SC}-1018$, left $\mathrm{m} 1$; SC-1021, right $\mathrm{m} 1$; SC-1026, left m2; SC-1027, right p3-m 1; SC-1042, left m2-4; SC-1136, right $\mathrm{m} 2$; SC-1 137, right $\mathrm{m} 1$ (damaged); SC-1161, left $\mathrm{m} 2$; SC-1 165, left $\mathrm{m} 1$; SC-1 166, left $\mathrm{ml}$; SC-1195, left $\mathrm{ml}$; SC1197 , left $\mathrm{m} 2$; SC-1201, right $\mathrm{m} 1-2$; SC-1234, right $\mathrm{p} 3-\mathrm{m} 3$; SC1235 , left $\mathrm{m} 2$; SC-1239, right $\mathrm{m} 2$ (talonid), $\mathrm{m} 3$; SC-1246, right $\mathrm{m} 2$; SC-1247, left m2; SC-1248, left m2; SC-1250, left m1-2; $\mathrm{SC}-1253$, left $\mathrm{m} 2$; SC-1258, right $\mathrm{m} 1$; SC-1268, right $\mathrm{m} 2, \mathrm{~m} 3$ (trigonid); SC-1269, right $\mathrm{m} 2-4$; SC-1272, right M2; SC-1277, left m 1-2; SC-1279, left p3-m4; SC-1280, left p3-m 1; SC-1282, right $\mathrm{m} 2$; SC-1291, right M2; SC-1297, right m2-3; SC-1303, left m1-3; SC-1304, right m1-4; SC-1314, left m2; SC-1315, right $\mathrm{m} 2-3$; SC-1317, left $\mathrm{m} 2-3$ (ramus pathologic); SC-1324, right i, p3-m 1; SC-1327, left m1-2; SC-1330, right $\mathrm{ml}$; SC1332, right $\mathrm{m} 1$; SC-1334, left P3-M4; SC-1335, left $\mathrm{m} 2$ (talonid), m3; SC-1340, left m2-3; SC-1347, right m1-3; SC-1349, right $\mathrm{m} 2-4$; SC-1355, right $\mathrm{m} 2$; SC-1358, left $\mathrm{ml} 1-2$; SC-1359, right $\mathrm{m} 1-4$ (damaged); SC-1363, right $\mathrm{m} 2-3$; SC-1368, left $\mathrm{m} 2-$ 3; SC-1380, left m2; SC-1386, left p3-m2; SC-1459, right p3m3; SC-1461, left C-M3 (Figure 15.4); SC-1466, left m2; SC1469 , right $\mathrm{m} 1-3$; SC-1473, right $\mathrm{p} 3-\mathrm{m} 3$; SC-1476, right $\mathrm{M} 1-$ 3; SC-1477, left M2-4; SC-1478, left m1; SC-1480, left m2; SC1481, left $\mathrm{m} 2-3$; SC-1482, right $\mathrm{m} 1-2$; SC-1485, right $\mathrm{m} 2$; SC1486, left $\mathrm{m} 1-4$; SC-1614, right $\mathrm{ml}$; SC-1615, right $\mathrm{m} 2$; SC1628, right p3-m4; SC-1629, left $\mathrm{m} 1-3$; SC-2880, right $\mathrm{m} 2-4$; SC-2884, left m1-2; SC-2893, left $\mathrm{ml-3}$; SC-2894, right $\mathrm{ml} 1-$ 3; SC-2909, right m2-3; SC-2920, left M1; SC-2926, right m12; SC-2937, right m1-2; SC-2941, right M1-3; SC-2943, left M1-2; SC-2947, right p3-m1; SC-2949, right m4; SC-2960, right m2; SC-2962, left m2; SC-2967, right m1-3; SC-2968, left p3-m3; SC-2981, left m1; SC-2982, right m2; SC-2984, right m2; SC-2992, right $\mathrm{m} 2$; SC-2997, left p3-m4; SC-3000, right p3-m2; SC-3004, left p3-m2; SC-3007, right m2-3; SC-3008, right M1-2; SC-3024, left p2-m3; SC-3029, right p3-m1; SC3031, right $\mathrm{m} 2$; SC-3033, right $\mathrm{m} 2-4$; SC-3036, left p3-m 1; SC3048, right m2; SC-3068, left m1-2; SC-3069, left m1; SC-3072, left p3; SC-3073, right m2-4; SC-3075, right p3-m4; SC-3084, left $\mathrm{m} 2-4$; SC-3087, right $\mathrm{m} 2$; SC-3144, left p3-m2; SC-3145, right $\mathrm{m} 1-2$; SC-3150, right $\mathrm{m} 1-3$; SC-3162, left $\mathrm{m} 2$; SC-3163, right $\mathrm{m} 1-4$; SC-3165, left M1; SC-3169, right m1-3; SC-3181, right $\mathrm{m} 1-2$; SC-3182, left $\mathrm{m} 1-2$; SC-3183, right $\mathrm{m} 2-3$; SC-3184, right m1-4; SC-3185, left p3-m4; SC-3189, right p3-m3; SC3190, right $\mathrm{m} 1-2$; SC-3193, left $\mathrm{m} 3$; SC-3195, right $\mathrm{p} 3$; SC3196, right M1; SC-3198, left m1-2; SC-3205, left m2; SC-3211, left $\mathrm{m} 2-3$; SC-3230, right $\mathrm{p} 3-\mathrm{m} 2$; SC-3232, right M2-3; SC3234 , left M1; SC-3235, right $\mathrm{m} 2$; SC-3236, right $\mathrm{m} 2$; SC-3240, right $\mathrm{m} 2$; SC-3241, right $\mathrm{m} 2-4$; SC-3262, right $\mathrm{m} 1$; SC-3269, left M2; SC-3273, right $\mathrm{m} 1$; SC-3277, right $\mathrm{m} 2$; SC-3278, right m2; SC-3279, left M1; SC-3290, left m2; SC-3292, right m2; SC-3293, right m2; SC-3384, left p3-m1; SC-3391, left m1-2; SC-3392a, left M1; SC-3392b, right M1; SC-3392d, right m4; SC-3395, left m2-3; SC-3405d, left M1; SC-3411, right p3-m1.

Localities of new material. - The following specimens are from the Pinturas Formation in the upper valley of the Rio Pinturas, northwest Provincia de Santa Cruz, at: 1) Portezuelo Sumich Norte (MACN SC numbers 407, 408, 416, 451, 476, 500); 2) 
Estancia Los Toldos (cerca del casco) (MACN SC-538); 3) Cerro de los Monos (MACN SC numbers 558, 578, 585, 603); 4) Loma de la Lluvia (MACN SC numbers $680,682,709,1161,1165$, $1166,3262,3277$ ); 5) Cauce Seca (MACN SC numbers 641, $643,644,659 ; 6$ ) Portezuelo Sumich Sur (MACN SC numbers $874,896,972,988,989 \mathrm{~B}, 990,991,1008,1011,1018,1021$, 1026, 1027, 1042, 1195, 1197, 1386, 1486, 3269, 3273); 7) Estancia La Cañada (MACN SC-3162); 8) Estancia Ana Maria (locality uncertain but in upper part of middle sequence of Pinturas Formation (MACN SC numbers 3189, 3190). The following specimens are from rocks provisionally referred to the Pinturas Formation in the central part of Provincia de Santa Cruz, at: 1) Lago Cardiel (Dumont locality) (MACN SC-1235); 2) Gobernador Gregores (uncertain level) (MACN SC numbers 731, 1239, 1615, 3068); 3) Gobernador Gregores (upper levels) (MACN SC-1615). The following specimens are from the Santa Cruz Formation along the Rio Chalia, at: 1) estaca 2 (MACN SC-3391); 2) estaca 3 (MACN SC numbers 3392a, 3392b, 3392d, 3395); 3) estaca 4 (MACN SC-3405d); 4) estaca 5 (MACN SC3411). The following specimens are from the Santa Cruz Formation, Provincia de Santa Cruz, at Monte León: 1) estaca 1 (MACN SC numbers 2884, 3181-3185); 2) estaca 6 (MACN SC numbers 1314,1315 ); 3) estaca 140 (MACN SC numbers 1246-1248); 4) estaca 142 (MACN SC numbers 1201, 1234, 1459, 2937, 2941, 2943, 2947, 2949, 3084); 5) Unit 27 (of Bown section) (MACN SC-2880), 6) Unit 1 (of Bown section, top of unit) (MACN SC-3169); 7) Monte León (indeterminate localities) (MACN SC numbers 1461, 1466, 1469, 1473, 1476-1478, 1480-1482, 1485). The following localities are from the Santa Cruz Formation at Monte Observación (Estancia Cañadon de las Vacas, Provincia de Santa Cruz), at: 1) estaca 7 (MACN SC numbers 2997, 3000, 3004, 3007, 3008, 3024, 3029, 3031, 3033, 3036, 3048, 3069, 3072, 3073, 3075, 3087); 2) estaca 12 (MACN SC numbers 3163, 3165); 3) estaca 13 (MACN SC-3198); 4) estaca 14 (MACN SC-3150); 5) estaca 17 (MACN SC numbers 2960, 2962); 6) estaca 19 (MACN SC numbers 3235, 3236, $3240,3241,3293,3384)$; 7) estaca 20 (MACN SC-1317); 8) estaca 21 (MACN SC numbers 1250, 1253); 9) estaca 25 (MACN SC numbers 2893, 2894, 2909, 3144, 3145); 10) estaca 29 (MACN SC numbers $1355,1358,1359,1363)$; 11) estaca 30 (MACN SC numbers 3290, 3292); 12) estaca 32 (MACN SC numbers 3205, 3211); 13) estaca 38 (MACN SC-1258); 14) estaca 39 (MACN SC-1268); 15) estaca 44 (MACN SC-1272); 16) estaca 47 (MACN SC-1368); 17) estaca 48 (MACN SC1269); 18) estaca 54 (MACN SC numbers 1277, 1279, 1280, 1282, 1291); 19) estaca 59 (MACN SC numbers 1297, 1303, 1304); 20) between estacas 59 and 60 (MACN SC-1324); 21) estaca 61 (MACN SC numbers 3193, 3195, 3196); 22) estaca 63 (MACN SC numbers 3230, 3232, 3234, 3278, 3279); 23) estaca 69 (MACN SC numbers 1327, 1330, 1332, 1334, 1335, 1340); 24) estaca 101 (MACN SC-1347); 25) estaca 106 (MACN SC-1349); 26) estaca 120 (MACN SC-1380); 27) estaca 141 (MACN SC-1136); 28) estaca 148 (MACN SC-1137); 29) estaca 203 (MACN SC numbers 2967, 2968, 2971, 2981, 2982, 2984); 30) estaca 204 (MACN SC numbers 2890, 3173); 31) estaca 206 (MACN SC numbers 2920, 2926, 2992); 32) Monte Observación, no estaca number (MACN SC numbers 1628, 1629).

In addition to the above localities, Acdestis oweni is also known from Coy Inlet, 5 miles south of Coy Inlet, Killik Aike, La Costa, La Cueva, Río Gallegos, "Santa Cruz," and Sehuen.

Distribution. - Santacrucian (early to middle Miocene), Pinturas and Santa Cruz Formations, Provincia de Santa Cruz, Argentina (Santacrucian temporal values $=56.8-96.2$ ).

Discussion. - The 180 new specimens of Acdestis oweni more than quintuple the hypodigm from that known a decade previously. With the transferral of Loomis' (1914) "Callomenus" praecursor to the new genus Acdestoides (it had been placed in Acdestis by Marshall, 1980), there remains no pre-Santacrucian representative of genus Acdestis. This arrangement, together with provision for the new species Acdestis lemairei (described below), makes both genus Acdestis and its two species, $A$. oweni and $A$. lemairei $\mathrm{n}$. sp., morphologically much more cohesive taxa. Nonetheless, $A$. oweni is clearly very closely related to the smaller and in some respects more advanced $A$. lemairei and overlaps with it slightly in both size and certain attributes of its dental morphology. These observations suggest the likelihood of a gradual, perhaps cladogenetic, splitting of the two species (see Discussion under $A$. lemaire $i$ and section on acdestine evolution, below).

The number and proportions of teeth in the mandible of Acdestis oweni are variable, as they are in A. lemairei. Where determinable, $A$. oweni has either four alveoli (six specimens) or three alveoli (four specimens) between the enlarged anterior incisor and p3. The $\mathrm{p} 3$ is almost always double-rooted; however, in SC-3024 it shows incipient fusion on the lingual side, and it is single-rooted in MACN 5561 (Marshall, 1980, fig. 33). The p2 (present only in SC-3024) is single-rooted. The penultimate anterior tooth (presumably an incisor) is generally enlarged and procumbent (SC numbers 1628, 2997, 3000, 3072, 3185, 3230) but may also be somewhat smaller and upright (SC-578 and SC-1473). From these data, it is concluded that Acdestis oweni possessed either five or six single-rooted teeth in addition to $\mathrm{p} 3$ and the molars and we interpret the dental formula of this species to be i2.c1.p2 or 3.m4, as in A. lemairei.

P3 is a massive tooth in Acdestis oweni (e.g., MACN numbers 8312 and SC-1334, YPM-PU 15225) and opposes both the diminutive $\mathrm{p} 3$ and the anterior part of the $\mathrm{m} 1$ trigonid. MACN SC-1334 also shows that at least some M4's of Acdestis oweni possessed a fully developed metacone.

First lower molars of Acdestis oweni are dominated by type 1 trigonid structure (about $61 \%$ ), in which there is a mure extending anteriorly from the metaconid and contacting the lingual margin of the protocristid. More rarely, A. oweni ml's possess types $2(27.5 \%)$ and $3(11.5 \%)$. Excellent unworn examples of type 1 trigonid structure occur in YPM-PU 15066, SC-972 (Figure 13), SC-1486 (Figure 15), SC-3163, and SC-3189, whereas good worn examples are SC-3004 and 3024.

In some specimens of both Acdestis oweni and A. lemairei $\mathrm{n}$. sp. (see below-especially in samples from higher levels in the Santa Cruz Formation) the cusps on $\mathrm{m} 1$ and $\mathrm{m} 2$ appear to be somewhat more internally distributed in occlusal view. This visual effect is due to a swelling of the enamel along the external border of the crown, as well as medial displacement of both trigonid and talonid cusps. The cusp displacement is quite marked when specimens of either species of Acdestis are compared with molars of Acdestoides, Acdestodon, and Trelewthentes, in which the molar cusps are clearly much more peripherally located. The net effect of this basal enamel expansion is reduction of available surface area in the trigonid and talonid basins.

Acdestis oweni was a large, probably frugivorous palaeothentid, with a body weight of approximately 450 grams (Strait et al., 1990, and unpublished data). See Figures 28-31 for molar area distributions of Acdestis oweni with respect to those for other Deseadan-Santacrucian Palaeothentidae.

\section{ACDESTIS LEMAIREI $\mathrm{n}$. $\mathrm{sp}$ \\ Figures 14, 15.5, 15.6}

Holotype.-MACN SC-1325 (Figure 14), left p3-m4.

Diagnosis. - Ramal depth beneath $\mathrm{m} 1$ on lingual side $4.0 \mathrm{~mm}$ or less $(3.3-4.0 \mathrm{~mm})$, and shallower than in A. oweni. Lower third premolar invariably minute, generally somewhat less elevated than in most $A$. oweni, and p 3 anteriorly canted, single- 
TABLE 5-Specimen data for first three lower molars, first two upper molars, and for $\mathrm{m} 1$ trigonid structure and ramal depth in Acdestis oweni Ameghino from various localities in the Pinturas and Santa Cruz Formations, Provincia de Santa Cruz. ln $=$ natural logarithm (L $\times$ W) of molar; MT $=\mathrm{m} 1$ trigonid type (types 1 through $4-$ see text); DRm $1=$ ramal depth beneath $\mathrm{m} 1$ on lingual side; $x=$ broken tooth. Measurements in millimeters.

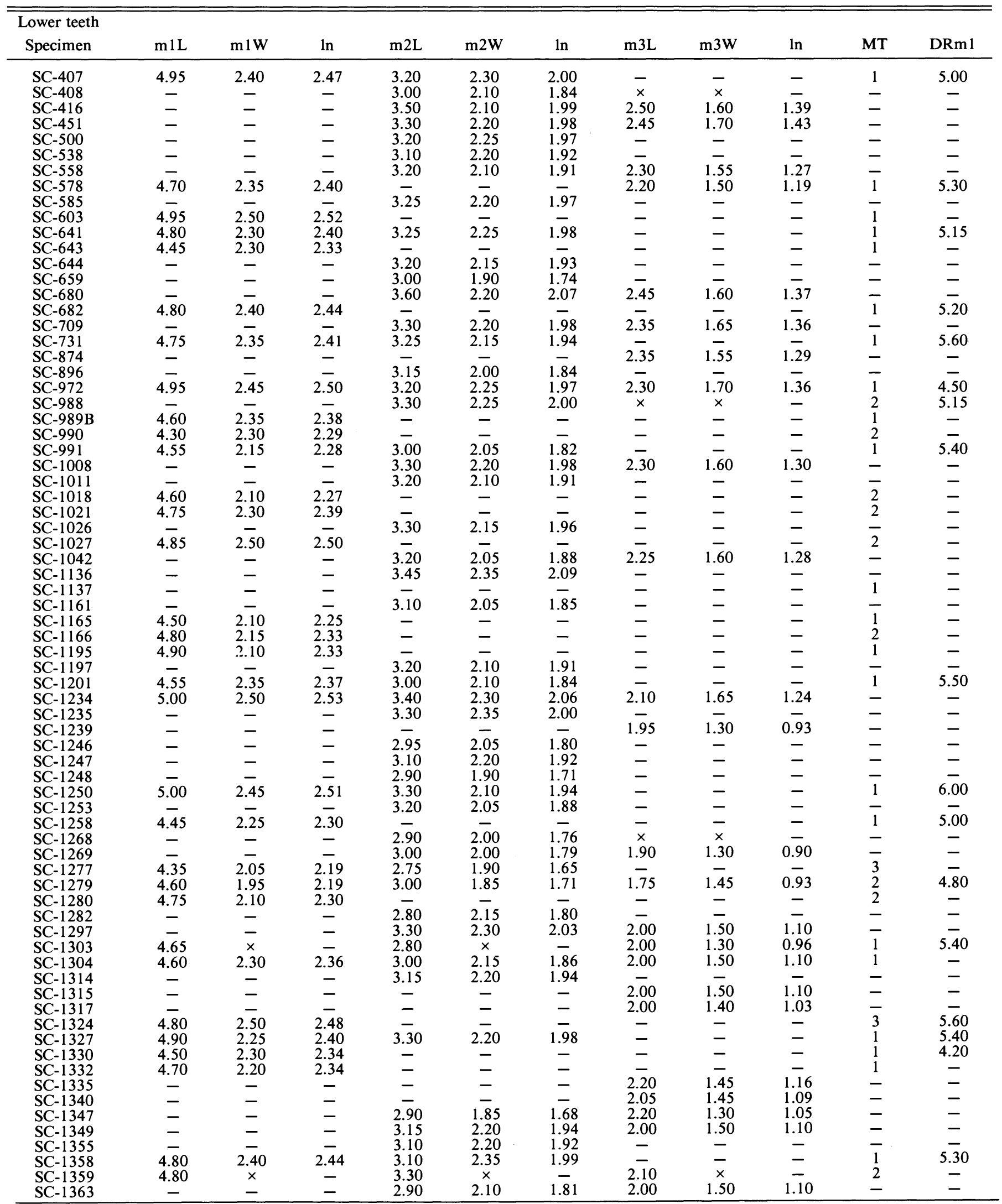


TABLE 5-Continued.

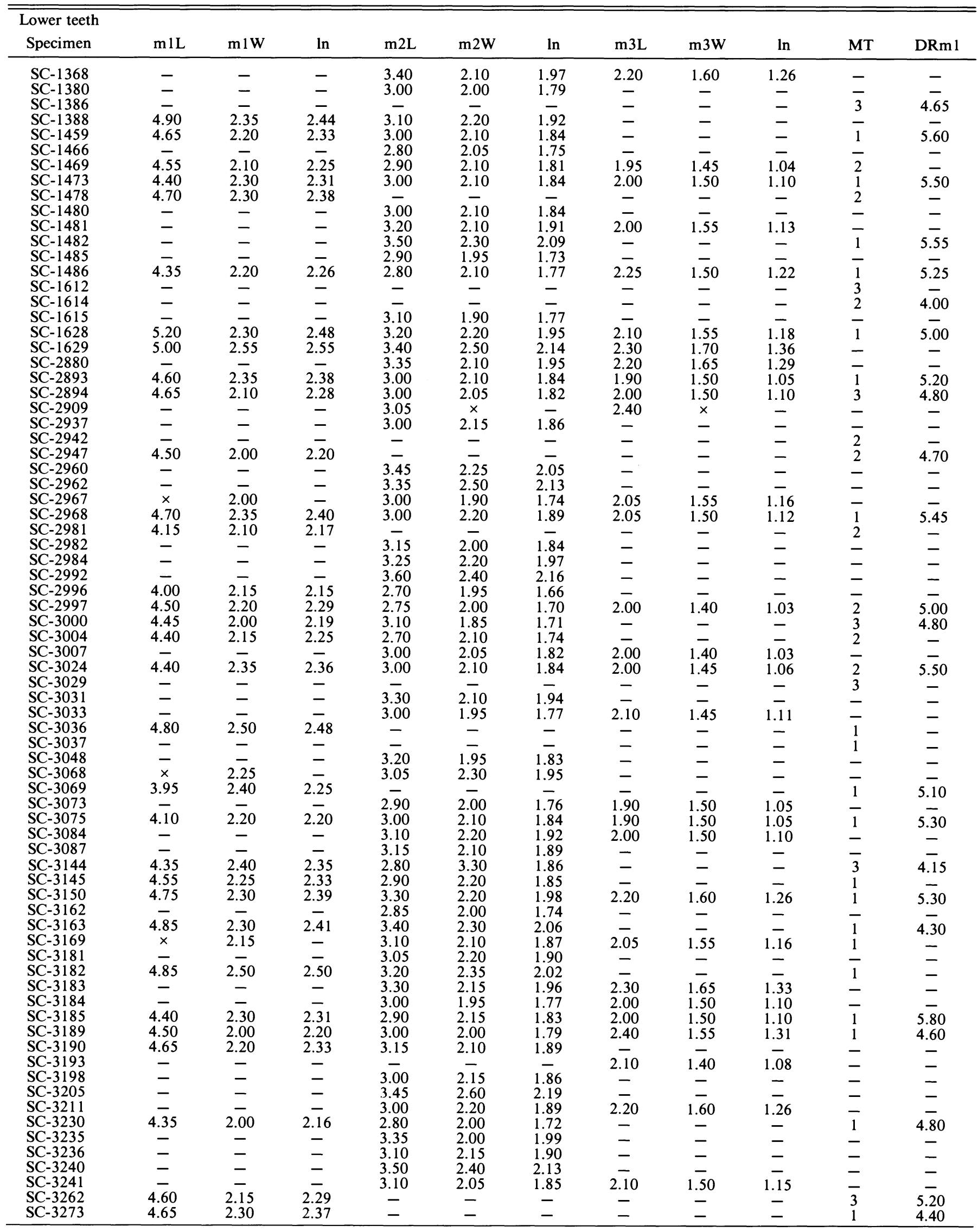


TABLE 5-Continued.

\begin{tabular}{|c|c|c|c|c|c|c|c|c|c|c|c|}
\hline \multicolumn{12}{|l|}{ Lower teeth } \\
\hline Specimen & $\mathrm{m} 1 \mathrm{~L}$ & $\mathrm{mlW}$ & $\ln$ & $\mathrm{m} 2 \mathrm{~L}$ & $\mathrm{~m} 2 \mathrm{~W}$ & $\ln$ & $\mathrm{m} 3 \mathrm{~L}$ & $\mathrm{~m} 3 \mathrm{~W}$ & $\ln$ & MT & $\mathrm{DRm} 1$ \\
\hline SC-3277 & - & - & - & 3.20 & 2.00 & 1.86 & - & - & - & - & - \\
\hline SC-3290 & - & - & - & 3.50 & 2.40 & 2.13 & - & - & - & - & - \\
\hline SC-3292 & - & - & - & 3.10 & 2.05 & 1.85 & - & - & - & - & - \\
\hline SC-3293 & - & - & - & 3.60 & $x$ & - & - & - & - & - & - \\
\hline SC-3384 & 4.65 & 2.25 & 2.35 & - & - & - & - & - & - & 2 & - \\
\hline SC-3391 & $x$ & 2.05 & - & 3.15 & 2.20 & 1.94 & - & - & - & - & - \\
\hline SC-3395 & - & - & - & 3.20 & 2.15 & 1.93 & 2.50 & 1.80 & 1.50 & - & - \\
\hline SC-3411 & $x$ & $\times$ & - & - & - & - & - & - & - & - & - \\
\hline \multicolumn{12}{|l|}{ Upper teeth } \\
\hline Specimen & M1L & M1W & $\ln$ & M2L & $\mathbf{M} 2 \mathbf{W}$ & $\ln$ & & & & & \\
\hline SC-1334 & 3.50 & 3.00 & 2.35 & 2.60 & 2.90 & 2.02 & & & & & \\
\hline SC-1461 & 3.90 & 3.40 & 2.58 & 2.70 & 3.30 & 2.19 & & & & & \\
\hline SC-1476 & 3.60 & 3.30 & 2.47 & 2.90 & 3.30 & 2.26 & & & & & \\
\hline SC-1477 & - & - & - & 2.80 & 3.00 & 2.13 & & & & & \\
\hline SC-2920 & 3.70 & 3.40 & 2.53 & - & - & - & & & & & \\
\hline SC-2943 & 3.50 & 3.00 & 2.35 & 2.60 & 2.90 & 2.02 & & & & & \\
\hline SC-3008 & 3.70 & 3.30 & 2.50 & 2.50 & 3.00 & 2.01 & & & & & \\
\hline SC-3165 & 3.70 & 3.60 & 2.59 & - & - & - & & & & & \\
\hline SC-3196 & 3.60 & 3.60 & 2.56 & - & - & - & & & & & \\
\hline SC-3232 & - & - & - & 2.70 & 3.10 & 2.12 & & & & & \\
\hline SC-3234 & 3.50 & 3.40 & 2.48 & - & - & - & & & & & \\
\hline SC-3269 & - & - & - & 2.70 & 3.30 & 2.19 & & & & & \\
\hline SC-3279 & 3.80 & 3.40 & 2.57 & - & - & - & & & & & \\
\hline SC-3392a & 3.85 & 3.30 & 2.54 & - & - & - & & & & & \\
\hline SC-3392b & 3.30 & 3.00 & 2.29 & - & - & - & & & & & \\
\hline SC-3405d & 3.50 & 3.10 & 2.38 & - & - & - & & & & & \\
\hline
\end{tabular}

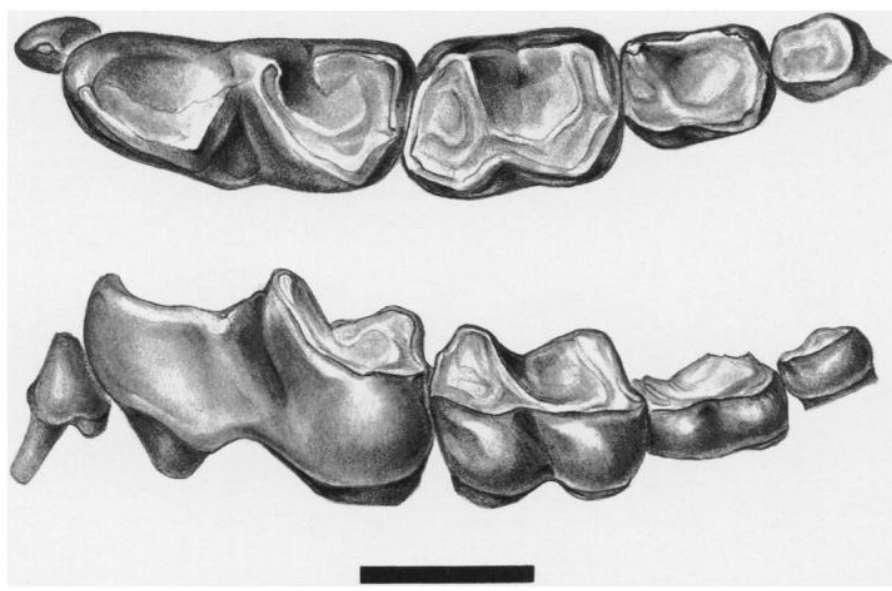

Figure 14-Acdestis lemairei n. sp. (Acdestinae); MACN SC-1 325 (type), left p3-m4, in occlusal (top) and labial (bottom) aspects (bar $=2.0$ $\mathrm{mm})$.

or double-rooted with double roots commonly fused on either lingual or labial side. Lower molars smaller than in A. oweni or at extreme lower end of size range in latter species. Lower first molar possesses type 2 trigonid structure (82\%) in all but four specimens, two specimens each with types 1 and 3. Mean of proportion of $\mathrm{m} 3 \mathrm{area} / \mathrm{m} 2$ area $=0.46(\mathrm{~N}=11)$, less than in
A. oweni and smallest of Palaeothentidae. See Table 6 for measurements.

Hypodigm. - The type specimen; MACN 5562, right p3-m 3; and the following MACN numbers: SC-685, left p3-m 1; SC1152, left p3, m2-3; SC-1206, left $\mathrm{ml-4}$; SC-1211, right $\mathrm{m} 2$ 3; SC-1212, left p3 and m4; SC-1339, right m1-3; SC-1348, right $\mathrm{m} 1$; SC-1460, right P3-M3 (Figure 15.6); SC-1612, right $\mathrm{m} 1$; SC-2882, left $\mathrm{m} 2-3$; SC-2889, right $\mathrm{p} 3$ and $\mathrm{m} 2-3$; SC-2902, left p3-m1; SC-2910, left m2; SC-2914, right m2-3; SC-2926, right $\mathrm{m} 1-2$; SC-2942, right p3-m 1; SC-2971, right p3-m 1; SC2996, left m 1-3; SC-2999, right m 1-4; SC-3005, left m 1-3; SC3009, left p3-m 1; SC-3034, right p3-m 1; SC-3037, left m 1; SC3038, left p3-m 1; SC-3040, right p3-m 1; SC-3041, right m12; SC-3044, right $\mathrm{m} 2-3$; SC-3070, left $\mathrm{ml-4}$; SC-3071, right p3-m4 (Figure 15.5); SC-3083, left p3; SC-3146, left p3-m1; SC-3183A, right $\mathrm{ml}$; SC-3187, left p3-m 1; SC-3229, right p3; SC-3231, right p2-m 1; SC-3244, right $\mathrm{m} 1$; SC-3282, right M1; SC-3283, left M1-4; SC-3285, left M1-2; SC-3287, left M2-3; SC-3409, right m1-2; SC-3413, top of skull, part of orbit, and right maxillary with $\mathrm{P} 2-\mathrm{M} 4$.

Localities of new material. - The following specimens are from the Pinturas Formation, at: 1) Loma de la Lluvia (MACN SC685); and 2) Cerro de los Monos (MACN SC-1612). The following specimens are from the Santa Cruz Formation exposed along the Rio Chalia, at estaca 5: MACN SC numbers 3409, 3413. The following specimens are from the Santa Cruz Formation (Provincia de Santa Cruz), at Monte León, at: 1) estaca

FIGURE $15-$ Dentitions of acdestine palaeothentids. 1 , Acdestodon bonapartei $\mathrm{n}$. gen. and sp., occlusal aspect of MACN CH-1472, right m1, $\times 15$. 2, Trelewthentes rothi $\mathrm{n}$. gen. and sp., occlusal aspect of MACN CH-1441, right $\mathrm{M} 1, \times 12$. 3, Trelewthentes rothi $\mathrm{n}$. gen. and sp., occlusal aspect of MACN CH-1481, left m3, × 15. 4, .4cdestis oweni Ameghino, occlusal aspect of MACN SC-1461, left C-M3, $\times 10.5$, Acdestis lemairei $\mathrm{n}$. sp., occlusal aspect of MACN SC-3071, right p3-m4, $\times 10.6$, Acdestis lemairei n. sp., occlusal aspect of MACN SC-1460, right P3-M3, $\times 10$. Stereopairs: $1,2,3$. 

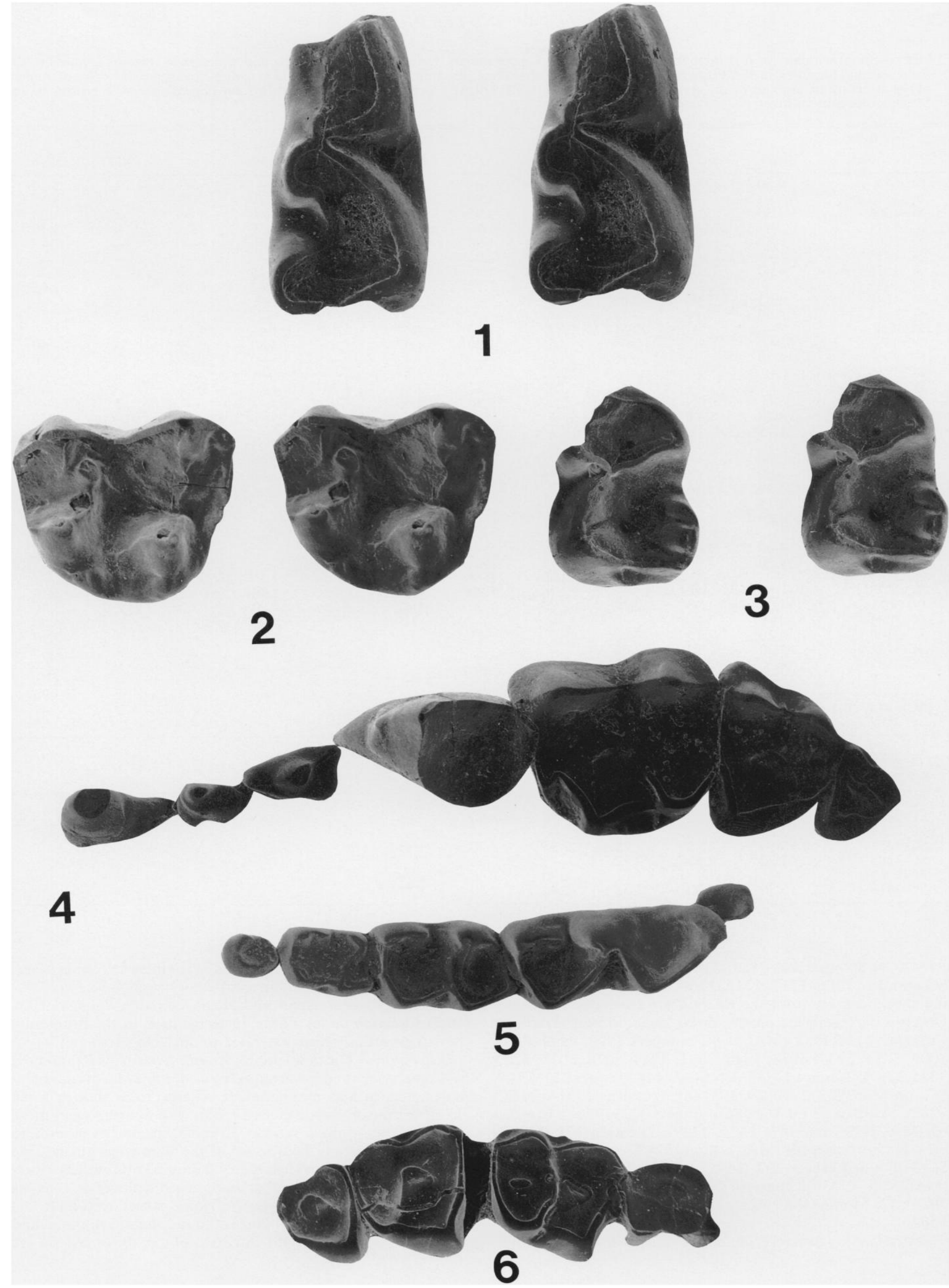
TABLE 6-Specimen data for first three lower molars, first two upper molars, ramal depth. and $\mathrm{m} 1$ trigonid structure in Acdestis lemairei $\mathrm{n}$. sp. from various localities in the Pinturas and Santa Cruz Formations, Provinicia de Santa Cruz. $\ln =$ natural logarithm $(\mathrm{L} \times \mathrm{W})$ of molar; $\mathrm{MT}=$ structure of trigonid of $\mathrm{m} 1$ (types 1 through 4-see text); DRml = depth of ramus beneath $\mathrm{m} 1$ on lingual side; $x=$ broken tooth. Measurements in millimeters.

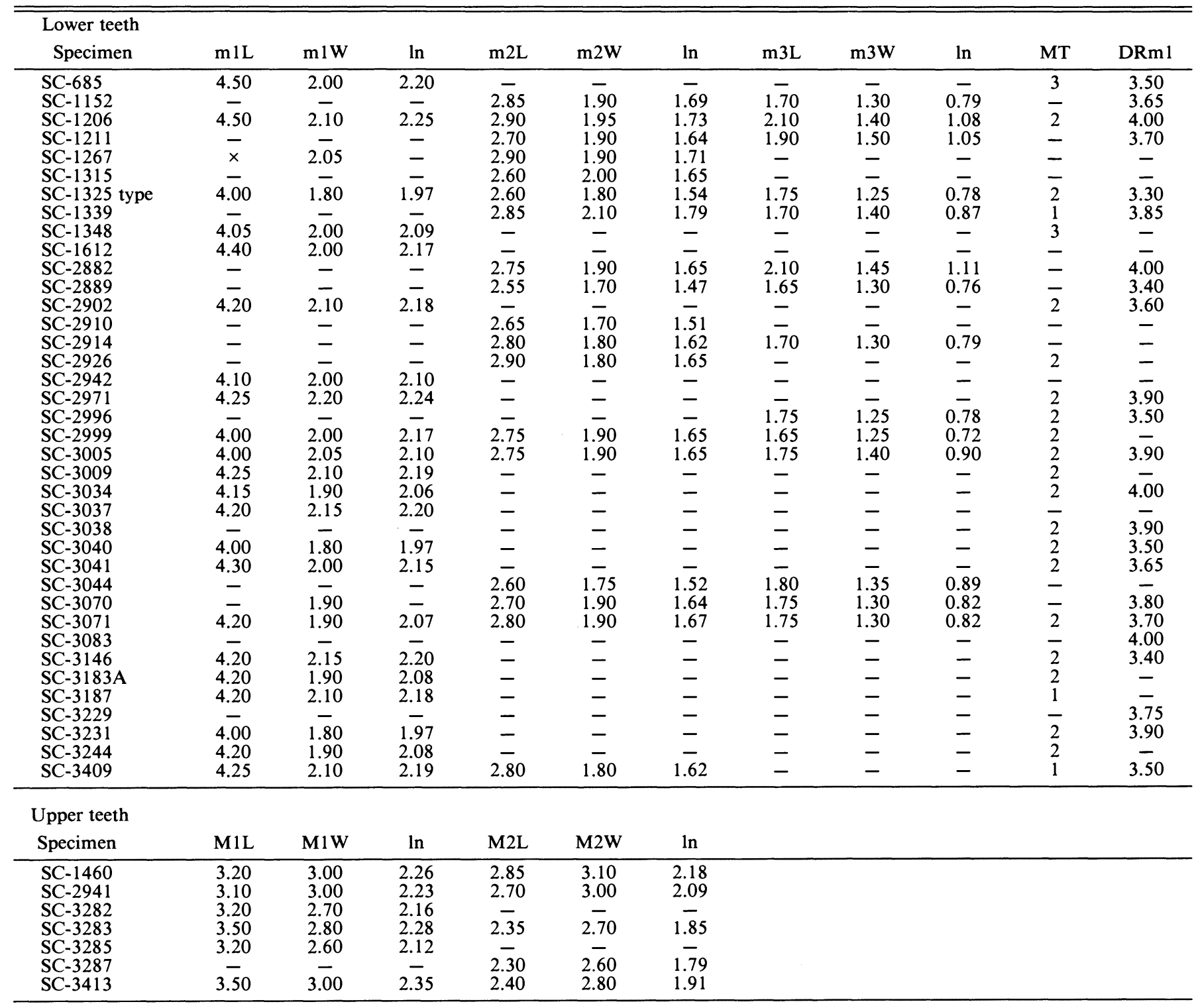

1 (MACN SC numbers 2882, 3183A); 2) estaca 142 (MACN SC numbers $1206,1211,1212,1460,2940,3083)$. The following specimens are from the Santa Cruz Formation at Monte Observación (Estancia Cañadon de las Vacas, Provincia de Santa Cruz), at: 1) estaca 7 (MACN SC numbers 2996, 2999, 3005, 3009, 3034, 3037, 3038, 3040, 3041, 3044, 3070, 3071, 3283 , 3285, 3287); 2) estaca 19 (MACN SC-3244); 3) estaca 25 (MACN SC numbers 2902, 2910, 2971, 3146); 4) estaca 61 (MACN SC3282); 5) estaca 63 (MACN SC numbers 3229, 3231); 6) estaca 69 (MACN SC numbers 1325, 1339); 7) estaca 101 (MACN SC-1348); 8) estaca 108 (MACN SC-1 152); 9) estaca 110 (MACN SC-3187); 10) estaca 203 (MACN SC-2971); 11) estaca 204 (MACN SC-2889); 12) estaca 206 (MACN SC numbers 2914, 2926); 13) Monte Observacíon, no estaca number (MACN SC5562).

Distribution. - Santacrucian (early to middle Miocene) Pin- turas and Santa Cruz Formations, Provincia de Santa Cruz, Argentina (Santacrucian temporal values $=66.4-92.6$ ).

Etymology. - For Henri and Helen Lemaire, dueños of Estancia Cañadon de las Vacas, in recognition of the hospitality they so generously have extended to our field personnel.

Discussion. - The new species Acdestis lemairei is represented by 43 specimens and is warranted by a combination of consistent morphological and measurement criteria, even though some characters in some specimens overlap with morphologies more typical of the $A$. oweni sample. Even so, specimens referred to $A$. lemairei generally possess all of the following: lingual side ramal depth beneath $\mathrm{m} 1$ less than $4.0 \mathrm{~mm}$; $\mathrm{p} 3$ minute, anteriorly canted, and with 1-2 roots or roots fused at level of alveolus on lingual side; $\mathrm{m} 1$ with type 2 trigonid structure (Figure 11) dominant; $\mathrm{m} 3$ smaller with respect to $\mathrm{m} 2$ than in $A$. oweni and with more reduced trigonid. Any two of the above criteria are 
alone adequate to identify the new species and most specimens possess all of them. In addition, inclusion of the hypodigm of $A$. lemairei in that of $A$. oweni expands the variability of the latter taxon beyond that expected for a single fossil species based on dental remains. This is true for both the somewhat arbitrarily separated ramal depth and tooth dimensions, but especially for the morphological breadth exhibited by pooled samples of $\mathrm{p} 3$, $\mathrm{m} 1$ trigonid structure, and $\mathrm{m} 3$ proportions and structure. Nonetheless, it is clear that $A$. oweni and the new species are closely related. Both species first appear in the middle part of the Pinturas Formation where they are already clearly distinct.

Tooth number and morphology is variable in Acdestis lemairei, as it is in $A$. oweni. The lower third premolar is generally very small and has two roots (SC numbers 2902, 2942, 2971, $3009,3040,3071,3146,3229,3231$ ), two roots labially and conjoined roots lingually (SC numbers 2889, 3034, 3038, 3083, 3187 ), or has but a single root (SC-1152). All but two known p3's of Acdestis oweni possess two clearly distinct roots.

Five mandibles of $A$. lemairei show four alveoli between the enlarged anterior incisor and p3 (SC numbers 3034, 3038, 3040, 307 1, 3146), and one has but three alveoli (SC-3083). A singlerooted p2 is present in SC-3231, with three alveoli between it and the anterior incisor. The alveolus for the tooth immediately posterior to that for the anterior incisor is relatively large in SC3038 and SC-3083, and was succeeded by a tooth about equal to it in size (the canine?). In SC numbers $3071,3034,3146$, and 3231 , however, the alveolus for the second tooth in the jaw is relatively small and is succeeded by that for a clearly larger tooth. This contrasts with the condition in $A$. oweni in which the alveolus for the second tooth in the jaw is generally as large as that for the third. The $\mathrm{p} 2$ is single-rooted in the sole specimen of $A$. lemairei that preserves it, and the lower dental formula of this species is interpreted as i2.c1.p2 or 3.m4, as it is in Acdestis oweni.

Shallow mandibular depth is used in part to separate $A$. lemairei from $A$. oweni (see also Walker, 1978, for jaw depth studies of Miocene lorisids). Utilization of this character as a diagnostic one is probably valid because it correlates well with other morphological differences seen and appears to be unrelated to ontological ages of individuals, based on tooth wear. For example, molar wear suggests that SC-2971 was the most senile of individuals of Acdestinae seen, yet it has a mandibular depth of $3.9 \mathrm{~mm}$, within the range of measurements for Acdestis lemairei. Numerous ontologically younger individuals in the hypodigm of $A$. oweni have much deeper rami.

The lower first molar in Acdestis lemairei has 82 percent of specimens evincing type 2 trigonid structure, in which the protocristid is in direct contact with an untwinned metaconid. Two specimens each ( $9 \%$ each) of $A$. lemairei possess trigonid structures 1 and 3. MACN 5562, SC-3071 (Figure 15), and SC-3231 are excellent examples of unworn type 2 trigonids; SC-3034 is a good worn example.

Acdestis lemairei was a medium-sized palaeothentid of uncertain feeding habits and with a body weight of approximately 150 grams (Strait et al., 1990, and unpublished data). See Figures 28-31 for molar area distributions of Acdestis lemairei with respect to those of other Deseadan-Santacrucian Palaeothentidae.

\section{Subfamily Palaeothentinae Sinclair, 1906}

Epanorthidae AMEGHINO, 1889.

Epanorthini WINGE, 1923 (partim).

Decastidae AMEghino, 1893.

Epanorthinae TrOUESSART, 1905

Palaeothentinae SINCLAIR, 1906.
Palaeothentidae OsGOoD, 1921.

Palaeothentinae MARSHALL, 1980 (partim).

Type genus. - Palaeothentes Ameghino, 1887, p. 5.

Revised diagnosis. - From the acdestines, the Palaeothentinae differ in having: 1) a relatively longer mandibular ramus; 2) invariably present, commonly double-rooted $\mathrm{p} 2 ; 3$ ) unreduced, double-rooted $\mathrm{p} 3$ that is generally elevated to, or nearly to, the height of the paraconid of $\mathrm{m} 1$; 4) $\mathrm{p} 3$ with a prominent anterobasal cusp; 5) lingual cusps of first three lower molars more peripherally (less internally) dispersed; 6) $\mathrm{m} 1$ protoconid generally taller than paraconid in unworn teeth; 7) $\mathrm{ml}$ with somewhat shorter paracristid; 8) m2-3 with pronounced vespiform constriction between trigonid and talonid (hypoflexid-entoconid notch area); 9) less widely separated Ml-2 protocone and hypocone; 10) less triangular M2-4; and 11) less reduced $M 4 / m 4$, these teeth generally possessing distinct cusps.

Included genera. - The type genus, Pilchenia Ameghino, 1903, p. 128, Carlothentes n. gen. (infra), and Propalaeothentes n. gen. (infra).

Distribution. - Deseadan (later Oligocene) through Santacrucian (Miocene) of Argentina; Deseadan of Bolivia; Santacrucian of Chile.

\section{Genus CARLOTHENTES n. gen.}

Epanorthus AMEGHINo, 1897, p. 500.

Palaepanorthus AMEGHINO, 1902, p. 77.

Palaeothentes LoOMIs, 1914, p. 221; PATTERSON AND MARSHALL, 1978, p. 85; Marshall, 1980, p. 85.

Type species. - Carlothentes chubutensis (Ameghino, 1897, p. 500); only known species.

Etymology. - For Cárlos Ameghino, nonpareil vertebrate fossil collector and early explorer of the Tertiary of Patagonia.

Distribution. - Deseadan (later Oligocene) rocks of Provincia del Chubut, Argentina; probably from Cabeza Blanca.

Diagnosis. - Differs from Palaeothentes and Propalaeothentes in having the $\mathrm{ml}$ metaconid situated very posteriorly and in having the $\mathrm{m} 1$ cristid obliqua bent at the midline. Differs from Pilchenia in having a shallower $\mathrm{ml}$ paraconid bifurcation, a short $\mathrm{m} 1$ paracristid, and in lacking: 1) crenulated enamel on $\mathrm{m} 1-3,2$ ) a twinned entoconid on $\mathrm{m} 2$, and 3) trenchant molar entoconids. Differs from Propalaeothentes in retention of the $\mathrm{m} 2$ paraconid, in having a tall, wide $\mathrm{p} 3$ with an anterobasal cusp, and in having a bifurcated $\mathrm{m} 1$ paraconid. Differs from Palaeothentes in having a short $\mathrm{m} 1$ paracristid and in retention of the $\mathrm{m} 2$ paraconid.

\section{CARlothentes ChUBUTENSIS (Ameghino, 1897)}

Epanorthus chubutensis AMEGHINO, 1897, p. 500.

Palaepanorthus chubutensis AMEGHINo, 1902, p. 77.

Palaeothentes chubutensis LOOMIS, 1914, p. 221.

Palaeothentes chubutensis PATTERSON AND MARSHALl, 1978, p. 85.

Palaeothentes chubutensis MARSHALL, 1980, p. 85.

Holotype. - MACN 52-378, right ramal fragment with p3-m2 and $\mathrm{m} 4$ (Marshall, 1980, fig. 28); only known specimen.

Revised diagnosis. - Only known species; as for genus. Measurements in Table 7.

Distribution. - Deseadan (later Oligocene) rocks; probably from Cabeza Blanca, Provincia del Chubut, Argentina.

Discussion. - Deseadan Carlothentes chubutensis is a second very large and ancient palaeothentine, yet one with a unique combination of generalized and derived dental features. The large, tall $\mathrm{p} 3$, short $\mathrm{m} 1$ trigonid, labially positioned $\mathrm{m} 1$ cristid obliqua, and presence of a paraconid on $\mathrm{m} 2$ are all generalized characters for palaeothentines and are to be expected in an early 
TABLE 7-Specimen data for lower first two molars, molar trigonid type, and ramal depth of Acdestoides praecursor (Loomis) n. gen., Acdestodon bonapartei n. gen. and sp., and for lower first three molars of Carlothentes chubutensis (Ameghino), Palaeothentes boliviensis Patterson and Marshall, Palaeothentes primus Ameghino, Palaeothentes pascuali $\mathbf{n} . \mathbf{s p}$., Pilchenia lucina Ameghino, Propalaeothentes lepidus (Ameghino), P. hatcheri $\mathrm{n}$. sp., and Hondathentes cazador Dumont and Bown from various localities in South America. $\ln =$ natural logarithm (L $\times$ W) of molar; DRm 1 = ramal depth beneath $\mathrm{m} 1$ on lingual side; $x=$ broken tooth. Measurements in millimeters.

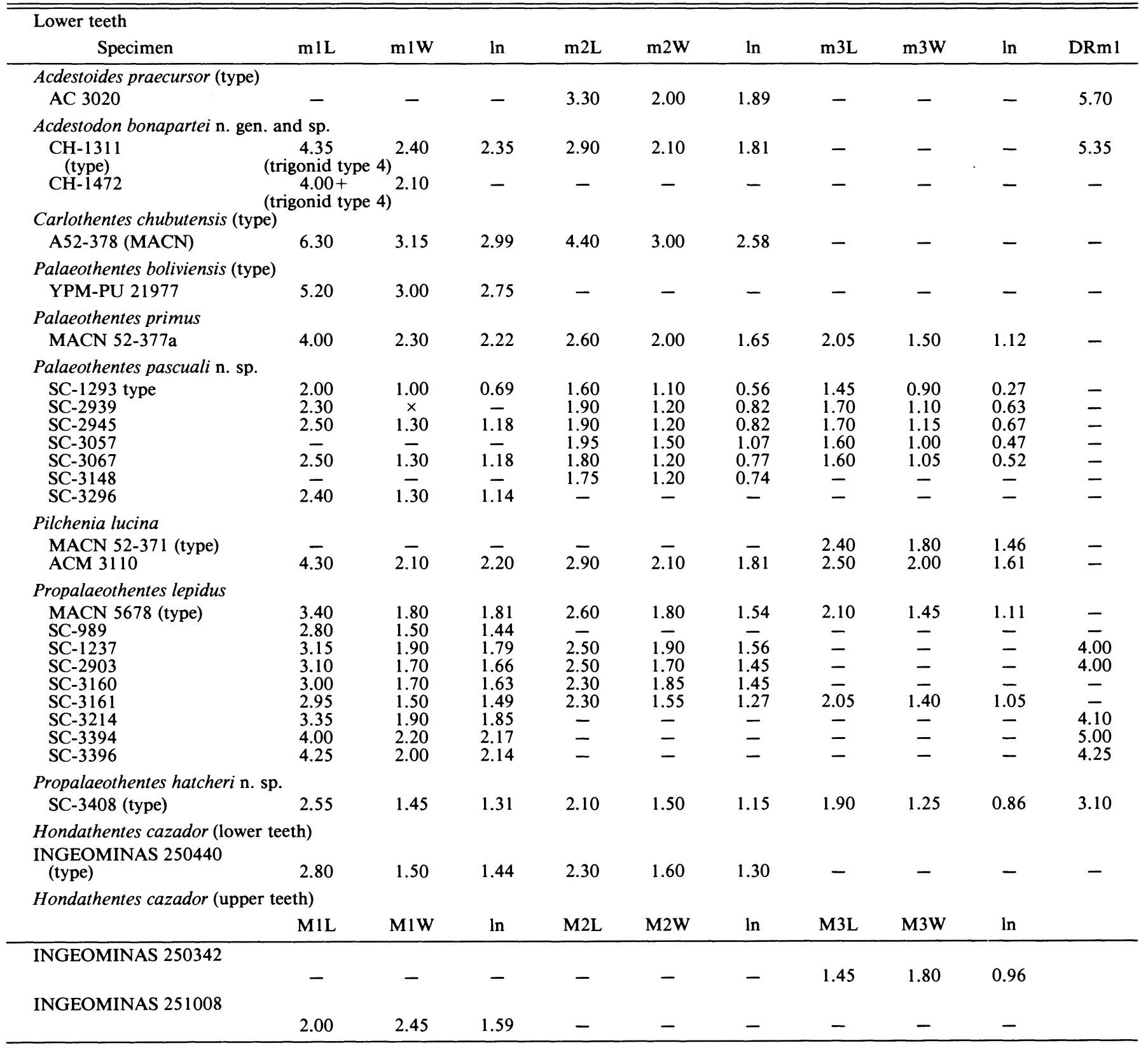

representative of the subfamily. The type $4 \mathrm{ml}$ trigonid structure may also be generalized (see lingual view of $\mathrm{ml}$ in Marshall, 1980, figure 28). In contrast, the posterior $\mathrm{m} 1$ metaconid and bent cristid obliqua (which is directed anterolingually from the hypoconid and turns sharply more lingually in the middle of its course) seem to be derived relative to the more anterior metaconid and straight cristid obliqua seen in other palaeothentine lower first molars.

The last two characters are also present in Deseadan Pilchenia lucina, from the same locality as Carlothentes chubutensis, suggesting the possibility that both taxa represent the same form. However, ACM 3110, the only available specimen referred to
Pilchenia lucina, has a twinned $\mathrm{m} 1$ metaconid, a twinned $\mathrm{m} 2$ entoconid, and crenulated enamel on m1-3-all highly derived features with respect to Carlothentes chubutensis (and, indeed, all other palaeothentines). Like Pilchenia, Carlothentes chubutensis must be regarded to be another very early palaeothentine, one not so generalized as contemporary Palaeothentes boliviensis (or the much younger Hondathentes, incertae sedis) and not so advanced as coeval Pilchenia lucina, but with incipient specializations reminiscent of $P$. lucina.

Carlothentes chubutensis was a very large palaeothentid of uncertain feeding habits. See Figures 28 and 29 for $\mathrm{m} 1$ and $\mathrm{m} 2$ areas in Carlothentes chubutensis with respect to molar area 
distributions in other Deseadan-Santacrucian species of Palaeothentidae.

Genus Palaeothentes Ameghino, 1887

Synonyms. -See Marshall, 1980, p. 53.

Type species. - Palaeothentes aratae Ameghino, 1887, p. 5.

Included species. - The type species and P. boliviensis Patterson and Marshall, 1978, p. 83; P. primus Ameghino, 1902, p. 77; P. marshalli n. sp.; P. migueli n. sp.; P. minutus Ameghino, 1887 , p. $6 ;$ P. pascuali n. sp.; P. intermedius Ameghino, 1887, p. 6; P. lemoinei Ameghino, 1887, p. 6.

Distribution. - Deseadan (later Oligocene) rocks, Salla-Luribay Basin, Bolivia; Colhuéhuapian (latest Oligocene or earliest Miocene) part of Sarmiento Formation, Provincia del Chubut, Argentina; Santacrucian (early to middle Miocene) Santa Cruz Formation, Provincia de Santa Cruz, Argentina (Santacrucian temporal value range $=8.0-98.9$ ); Santacrucian rocks, Alto Río Cisnes area, Chile.

Revised diagnosis. - Palaeothentes is distinguished from Carlothentes in: 1) a long paracristid on $\mathrm{m} 1$; 2) loss of the $\mathrm{m} 2$ paraconid; 3 ) having a more anteriorly situated $\mathrm{ml}$ metaconid; and 4) in lacking an $\mathrm{m} 1$ cristid obliqua that is bent at the midline. Palaeothentes differs from Pilchenia in: 1) a relatively taller p3; 2) a shorter valley separating moieties of the twinned $\mathrm{m} 1$ paraconid ( $P$. marshalli and $P$. migueli approximate but do not match the extreme condition seen in Pilchenia); 3) a transversely broader protocristid; 4) less trenchant molars; 5) untwinned $\mathrm{m} 2$ entoconid; 6) m 1-3 lacking crenulated enamel; and 7) generally lacking the $\mathrm{m} 2$ paraconid. From Propalaeothentes, Palaeothentes differs in having a much taller p3 with an anterobasal cusp, a bifurcated $\mathrm{m} 1$ paraconid, and longer and more trenchant entoconids on $\mathrm{m} 1$ and $\mathrm{m} 2$.

\section{PALAEOTHENTES BOLIVIENSIS}

Patterson and Marshall, 1978

Palaeothentes boliviensis PATterson AND MARShall, 1978, p. 83; MARSHALl, 1980, p. 85 .

Holotype. - YPM-PU 21977, right ramal fragment with p3ml (Marshall, 1980, fig. 27); only known specimen.

Revised diagnosis. - Teeth smaller than in Carlothentes chubutensis and Palaeothentes aratae; considerably larger than in all other species of Palaeothentes. Lower third premolar larger than in all other Palaeothentes and broad posteriorly, in contrast to most other species of Palaeothentes. Lower first molar with type 2 trigonid structure. Bifurcation of $\mathrm{ml}$ paraconid weakly developed, about as in $P$. aratae. Postcristid of $\mathrm{m} 1$ transversely narrower than in all other species of Palaeothentes. Talonid of $\mathrm{m} 1$ relatively shorter and $\mathrm{m} 1$ metaconid and paraconid closer together than in $P$. aratae. Measurements in Table 7.

Distribution. - Deseadan (later Oligocene) rocks of Salla-Luribay Basin, Bolivia (locality V-2 of Braniša).

Discussion. - Comparison of the type and only known specimen of $P$. boliviensis with teeth of other palaeothentines reveals $P$. boliviensis to have been a very generalized form in: 1) the very large, tall p3 with a broad posterior lobe; 2 ) the very short furrow separating the twinned moieties of the $\mathrm{m} 1$ paraconid; 3 ) the anteroposteriorly short $\mathrm{m} 1$ talonid; and 4) the short trigonid with relatively closely set metaconid and paraconid. The latter two conditions are generalized with respect to all other palaeothentids except Hondathentes. The paraconid furrow is short and is about as in $P$. primus and $P$. aratae. Although heavily worn, $\mathrm{ml}$ in $P$. boliviensis appears to have a type 2 trigonid structure and, convergently with Pilchenia lucina, has a transversely very narrow postcristid.

Pending access to additional materials of $P$. boliviensis, this species must be regarded to be a very large yet morphologically generalized early member of the Palaeothentinae whose closest affinities to other species are uncertain.

Palaeothentes boliviensis was a very large palaeothentid of uncertain feeding habits. See Figure 28 for $\mathrm{ml}$ area in Palaeothentes boliviensis, with respect to $\mathrm{m} 1$ area distributions in other Deseadan-Santacrucian Palaeothentidae.

\section{PAlaeothentes PRIMUS (Ameghino, 1902)}

Figure 24.1

Palaepanorthus primus AmEghiNo, 1902, p. 77 (nomen nudum).

Holotype.-MACN 52-373a, edentulous left ramus.

Revised diagnosis. - Medium-sized palaeothentine, about the size of $P$. intermedius. Differs from $P$. intermedius in having smaller ratio of $\mathrm{m} 3$ area to $\mathrm{m} 2$ area $(0.59)$ and with taller $\mathrm{p} 3$. Differs from contemporary $P$. marshalli in having much smaller $\mathrm{m} 3 / \mathrm{m} 2$ area, from $P$. migueli in its much larger molars, and from both $P$. marshalli and $P$. migueli (and most other species of Palaeothentes) in having a shallower and much shorter valley separating moieties of twinned $\mathrm{m} 1$ paraconid. Differs from all other palaeothentids excepting some Palaeothentes aratae in junction of $\mathrm{ml}$ cristid obliqua with protocristid at a position labial to metaconid and in having a very anterolabially-posterolingually oblique $\mathrm{m} 1$ protocristid. Differs from $P$. aratae in its considerably smaller molar size.

Hypodigm. - The type specimen and the following MACN specimens: $52-370 \mathrm{c}$, right p3; 52-373b, left m1-3; 52-373c, left i1; 52-373d, il root; 52-377a, right p3-m3 (Figure 24.1). MMP M-944, right m2-4; MLP 77-VI-13-2, right m 1-2; MLP 77-VI13-6, left m 1-2; MLP 77-VI-13-17, right p3-m4; MLP 77-VI13-22, left p3, m2-3; AMNH 29670, right m2-3.

Distribution. - Colhuéhuapian (latest Oligocene); ColhuéHuapí Formation, Gran Barranca, southern Provincia del Chubut, Argentina. Locality of AMNH 29670 uncertain but probably also from the Gran Barranca.

Discussion. - Palaeothentes primus possesses a combination of generalized and derived dental features that, among palaeothentids, is matched only by the unusual dental patterns of Propalaeothentes and Hondathentes. The third lower premolar is tall and the $\mathrm{m} 1$ paraconid twinning is faint, both conditions generalized and as in $P$. aratae; however, relative $\mathrm{m} 3$ size is derived in being more reduced relative to $\mathrm{m} 2$ than in any other palaeothentids excepting $P$. aratae and the two species of $A C$ destis. Most significantly, the $\mathrm{m} 1$ cristid obliqua is confluent with the greatly expanded protocristid at a position labial to the metaconid, a condition otherwise seen only in a single specimen of Palaeothentes aratae.

Marshall (1980) believed Palaeothentes primus to be in the ancestry of the equisized Santacrucian species $P$. intermedius. $P$. primus differs considerably from $P$. intermedius in having a taller p3 and a somewhat more reduced $\mathrm{m} 3$, in possessing (in at least some specimens) a type $4 \mathrm{ml}$ trigonid structure $(P$. intermedius possesses types 1 and 2), and in the position of the confluence of the $\mathrm{m} 1$ cristid obliqua with the postcristid. All of these characters are shared with the much larger Santacrucian species Palaeothentes aratae, which in several features is one of the most generalized species of Palaeothentes. In addition, both $P$. primus and $P$. aratae share the presence of an anterior mure on the $\mathrm{ml}$ entoconid, a very anterolabially-posterolingually oblique protocristid (both are derived characters), and confluence of the cristid obliqua with the middle of the postcristid, labial to the metaconid (a generalized character present in some $P$. aratae). Palaeothentes primus has additionally lost the anterobasal cusp on $\mathrm{p} 3$, whereas it is primitively present but very faintly developed in Palaeothentes aratae. 

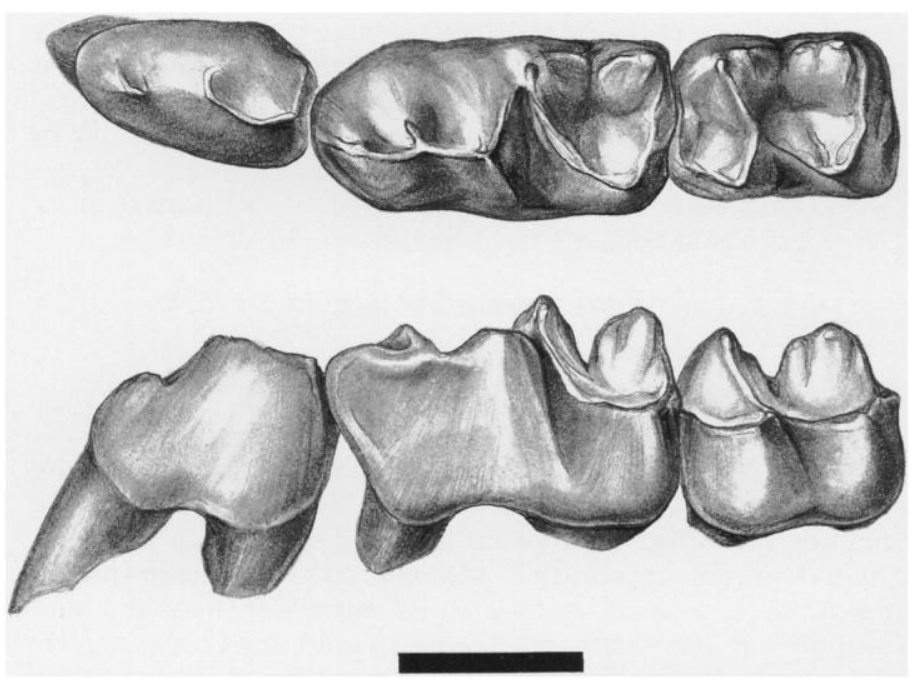

FIGURE 16-Palaeothentes marshalli n. sp. (Palaeothentinae); MACN $\mathrm{CH}-1325$ (type), left p3-m2, in occlusal (top) and labial (bottom) aspects $(\mathrm{bar}=2.0 \mathrm{~mm})$.

Palaeothentes primus was a medium-sized palaeothentine of uncertain dietary habits. See Table 7 for measurements and Figures 28-31 for molar dimensions of Palaeothentes primus with respect to those of other Deseadan-Santacrucian Palaeothentidae.

\section{PALAeOthentes MARShalli $n$. sp.}

Figures 16, 24.2

Holotype. - MACN CH-1325, left mandibular ramus with p3$\mathrm{m} 2$ (Figure 16).

Diagnosis. - Medium-sized palaeothentine, approximately intermediate in size between Palaeothentes intermedius and $\mathrm{AC}$ destis oweni, about the size of Palaeothentes primus; teeth considerably larger than in Palaeothentes pascuali and $P$. minutus, and teeth considerably smaller than in Palaeothentes lemoinei, $P$. aratae, and $P$. boliviensis. Lower third premolar large, tworooted and variable in height from equal to that of the paraconid of $\mathrm{m} 1$ to somewhat shorter. First lower molar with type $1(43 \%$, $N=3)$ or type $2(57 \%, N=4)$ trigonid structure. Second lower molar with less explicit vespiform constriction between trigonid and talonid than in other species of Palaeothentes, and mean of $\mathrm{m} 3 / \mathrm{m} 2$ area ratio smaller than in $P$. pascuali, larger than in all other Palaeothentes. Differs from Palaeothentes primus in having much deeper and longer bifurcation of $\mathrm{ml}$ paraconid and in having cristid obliqua confluent with metaconid, not at more labial position on protocristid. Upper molars more triangular and transverse than in $P$. intermedius (but less than in $P$. lemoinei); M1-2 with a shorter talon than $P$. intermedius. Upper molars with hypocone area not expanded lingually, unlike Palaeothentes minutus, $P$. pascuali, $P$. intermedius, and $P$. aratae and same as in Palaeothentes lemoinei and Hondathentes cazador. See Table 8 for measurements.

Hypodigm. - The type specimen and MACN numbers $\mathrm{CH}-$ 1313, right $\mathrm{ml}$; $\mathrm{CH}-1319$, right $\mathrm{ml} ; \mathrm{CH}-1329$, left $\mathrm{ml} ; \mathrm{CH}-1333$, right $\mathrm{ml} ; \mathrm{CH}-1334$, left $\mathrm{ml} ; \mathrm{CH}-1337$, left $\mathrm{ml}-2 ; \mathrm{CH}-1339$, left $\mathrm{m} 2$; $\mathrm{CH}-1341$, right $\mathrm{m} 2-4$; $\mathrm{CH}-1345$, left $\mathrm{m} 1$; $\mathrm{CH}-1346$, left $\mathrm{ml} ; \mathrm{CH}-1347$, left $\mathrm{ml}$; $\mathrm{CH}-1349$, left $\mathrm{ml} ; \mathrm{CH}-1350$, right $\mathrm{ml}$; $\mathrm{CH}-1351$, left $\mathrm{m} 1 ; \mathrm{CH}-1353$, left $\mathrm{ml}$; $\mathrm{CH}-1354$, right $\mathrm{ml}$; CH-1355, left m1; CH-1356, left $\mathrm{ml}$; CH-1357, left $\mathrm{ml}$; $\mathrm{CH}-1358$, left $\mathrm{ml}$; $\mathrm{CH}-1359$, left $\mathrm{ml}$; $\mathrm{CH}-1360$, right $\mathrm{ml}$; $\mathrm{CH}-$ 1361, left $\mathrm{m} 2-3$; $\mathrm{CH}-1365$, right $\mathrm{m} 2$; $\mathrm{CH}-1366$, left $\mathrm{m} 2$; $\mathrm{CH}-$ 1367 , left $\mathrm{m} 2$; $\mathrm{CH}-1368$, right $\mathrm{m} 2 ; \mathrm{CH}-1373$, right $\mathrm{m} 2-3$;
CH-1374, left m1-2; CH-1379, left m1; CH-1382, left m1; $\mathrm{CH}-1383$, right $\mathrm{ml}$; $\mathrm{CH}-1387$, right $\mathrm{ml}$; $\mathrm{CH}-1389$, left $\mathrm{ml}$; $\mathrm{CH}-1390$, right $\mathrm{ml}$; $\mathrm{CH}-1392$, right $\mathrm{ml}$; $\mathrm{CH}-1394$, right $\mathrm{ml}$; $\mathrm{CH}-1395$, right $\mathrm{ml}$; $\mathrm{CH}-1399$, right $\mathrm{ml}$; $\mathrm{CH}-1407$, left $\mathrm{ml}$; $\mathrm{CH}-1408$, left $\mathrm{ml} ; \mathrm{CH}-1409$, right $\mathrm{ml} ; \mathrm{CH}-1412$, right $\mathrm{ml}$; $\mathrm{CH}-1414$, right $\mathrm{m} 2$; $\mathrm{CH}-1415$, left $\mathrm{m} 2$; $\mathrm{CH}-1416$, right $\mathrm{m} 1$; $\mathrm{CH}-$ 1417 , right $\mathrm{ml}$; $\mathrm{CH}-1419$, left $\mathrm{ml} ; \mathrm{CH}-1420$, right $\mathrm{ml} ; \mathrm{CH}-$ 1425, right $\mathrm{m} 2$; $\mathrm{CH}-1427$, left $\mathrm{m} 2$; $\mathrm{CH}-1429$, right $\mathrm{m} 2$; $\mathrm{CH}-$ 1432, left m2; CH-1440, left M1-3 (Figure 24.2); CH-1445, right M1; CH-1449, right M1; CH-1453, left M1; CH-1454, left M1; CH-1456, right M1; CH-1458, right $\mathrm{M} 2$; $\mathrm{CH}-1461$, right $\mathrm{M} 2$; $\mathrm{CH}-1463$, right $\mathrm{M} 1 ; \mathrm{CH}-1473$, right $\mathrm{ml}$; $\mathrm{CH}-1479$, right $\mathrm{ml}$; CH-1482, right $\mathrm{m} 1$.

Distribution. - Late Colhuéhuapian (latest Oligocene or earliest Miocene) upper part of Trelew Member of the Sarmiento Formation in the valley of the Rio Chubut, near Gaiman, in the eastern part of Provincia del Chubut, Argentina (La Cantera locality of Fleagle and Bown, 1983).

Etymology.-For Larry G. Marshall, in recognition of his outstanding contributions to knowledge of the Palaeothentidae.

Discussion. - Teeth of Palaeothentes marshalli are the most abundantly represented palaeothentid remains at La Cantera. In $P$. marshalli, $\mathrm{m} 3$ is quite large relative to $\mathrm{m} 2$; and this size proportion is greater than in all other Palaeothentes, excepting $P$. pascuali and a few specimens of $P$. minutus. $\mathrm{CH}-1358$, a specimen of $\mathrm{m} 1$, and $\mathrm{CH}-1366$, an $\mathrm{m} 2$, are very narrow and rather small compared with those teeth in the remainder of the $P$. marshalli sample. They could conceivably belong to another otherwise unrepresented taxon; however, they are too large and too different in structure for inclusion in the new species $\mathrm{Pa}$ laeothentes migueli, and morphologically approximate the remainder of the $P$. marshalli sample. The first lower molar possesses type 2 trigonid structure with a transverse protocristid in four specimens, and type 1 trigonid structure in three specimens. In contrast to Palaeothentes intermedius, the talon on M1-2 in $P$. marshalli is relatively small, causing those teeth to appear more triangular in occlusal view (Figure 24.2).

With the exception of the much longer and deeper valley separating moieties of the twinned $\mathrm{m} 1$ paraconid, most of the diagnostic characters of Palaeothentes marshalli are generalized relative to the condition in $P$. intermedius, a younger palaeothentine of similar size; however, the deeper $\mathrm{ml}$ paraconid bifurcation is a specialized character prohibiting $P$. marshalli from inclusion in the ancestry of $P$. intermedius, despite otherwise very close morphologic similarities. Similarly, ml paraconid morphology and the confluence of the $\mathrm{m} 1$ cristid obliqua alone prevent including $P$. marshalli in Palaeothentes primus, its contemporary species of equal size.

Palaeothentes marshalli was a medium-sized, probably faunivorous palaeothentid (Strait et al., 1990, and unpublished data). See Figures 28-31 for molar area distributions of Palaeothentes marshalli relative to those of other Deseadan-Santacrucian Palaeothentidae.

\section{Palaeothentes Migueli n. sp.} Figures 17, 25.1

Holotype.-MACN CH-1338, right mandibular ramus with p3-m2 (Figure 17).

Diagnosis. -Minute palaeothentine, $\mathrm{ml-3}$ length $=5.7 \mathrm{~mm}$ ( $5.0 \mathrm{~mm}$ in Palaeothentes pascuali and $6.35 \mathrm{~mm}$ in $P$. minutus), much smaller than in contemporary Palaeothentes primus and $P$. marshalli. Differs from all other Palaeothentes excepting $P$. marshalli in having very long and deep valley separating moieties of twinned $\mathrm{ml}$ paraconid. Type 1 trigonid structure dominant $(89 \%, N=8)$, one specimen $(11 \%)$ with type 2 . See Table 9 for measurements. 
TABLE 8-Specimen data for first three lower molars and first two upper molars of Palaeothentes marshalli $\mathrm{n}$. sp., from La Cantera in the Sarmiento Formation, Provincia del Chubut. $\ln =$ natural logarithm $(\mathrm{L} \times \mathrm{W})$ of molar; $x=$ broken tooth. Measurements in millimeters.

\begin{tabular}{|c|c|c|c|c|c|c|c|c|c|}
\hline \multicolumn{10}{|c|}{ Lower teeth } \\
\hline Specimen & $\mathrm{m} 1 \mathrm{~L}$ & $\mathrm{~m} 1 \mathrm{~W}$ & $\ln$ & $\mathrm{m} 2 \mathrm{~L}$ & $\mathrm{~m} 2 \mathrm{~W}$ & $\ln$ & $\mathrm{m} 3 \mathrm{~L}$ & $\mathrm{~m} 3 \mathrm{~W}$ & $\ln$ \\
\hline $\mathrm{CH}-1313$ & 4.00 & 2.00 & 2.08 & - & - & - & - & - & - \\
\hline $\mathrm{CH}-1325$ & 4.00 & 1.90 & 2.03 & 2.40 & 1.80 & 1.46 & - & - & - \\
\hline $\mathrm{CH}-1329$ & 3.85 & 1.70 & 1.88 & - & - & - & - & - & - \\
\hline $\mathrm{CH}-1333$ & 4.00 & 2.10 & 2.13 & - & - & - & - & - & - \\
\hline $\mathrm{CH}-1334$ & 4.05 & 1.80 & 1.99 & - & - & - & - & - & - \\
\hline $\mathrm{CH}-1337$ & - & - & - & 2.50 & 1.45 & 1.29 & - & - & - \\
\hline $\mathrm{CH}-1339$ & - & - & - & 2.70 & 1.80 & 1.58 & $\overline{-}$ & $\overline{-}$ & - \\
\hline $\mathrm{CH}-1341$ & - & - & - & 2.50 & 1.85 & 1.53 & 2.00 & 1.55 & 1.13 \\
\hline $\mathrm{CH}-1345$ & 3.80 & 1.80 & 1.92 & - & - & - & - & - & - \\
\hline $\mathrm{CH}-1346$ & 4.10 & 2.10 & 2.15 & - & - & - & - & - & - \\
\hline $\mathrm{CH}-1347$ & 3.70 & 1.80 & 1.90 & - & - & - & - & - & - \\
\hline $\mathrm{CH}-1349$ & 3.90 & 1.90 & 2.00 & - & - & - & - & - & - \\
\hline $\mathrm{CH}-1350$ & 3.70 & 1.60 & 1.78 & - & - & - & - & - & - \\
\hline $\mathrm{CH}-1351$ & 3.90 & 2.00 & 2.05 & - & - & - & - & - & - \\
\hline $\mathrm{CH}-1353$ & 3.70 & 2.10 & 2.05 & - & - & - & - & - & - \\
\hline $\mathrm{CH}-1354$ & 3.80 & 1.80 & 1.92 & - & - & - & - & - & - \\
\hline $\mathrm{CH}-1355$ & 4.10 & 1.90 & 2.05 & - & - & - & - & - & - \\
\hline $\mathrm{CH}-1356$ & 3.80 & 2.00 & 2.03 & - & - & - & - & - & - \\
\hline $\mathrm{CH}-1357$ & 3.50 & 1.75 & 1.81 & - & - & - & - & - & - \\
\hline $\mathrm{CH}-1358$ & 3.20 & 1.60 & 1.63 & - & - & - & - & - & - \\
\hline $\mathrm{CH}-1360$ & 3.70 & 1.70 & 1.84 & - & - & - & - & - & - \\
\hline $\mathrm{CH}-1361$ & - & - & - & 2.20 & 1.80 & 1.38 & 2.15 & 1.45 & 1.14 \\
\hline $\mathrm{CH}-1365$ & - & - & - & 2.40 & 1.75 & 1.44 & - & - & - \\
\hline $\mathrm{CH}-1366$ & - & - & - & 2.30 & 1.60 & 1.30 & - & - & - \\
\hline $\mathrm{CH}-1367$ & - & - & - & 2.40 & 1.70 & 1.41 & - & - & - \\
\hline $\mathrm{CH}-1368$ & - & - & - & 2.45 & 1.75 & 1.46 & - & - & - \\
\hline $\mathrm{CH}-1373$ & - & - & - & 2.50 & 1.80 & 1.50 & 2.00 & 1.60 & 1.16 \\
\hline $\mathrm{CH}-1374$ & 3.85 & 2.00 & 2.04 & 2.40 & 1.90 & 1.52 & - & - & - \\
\hline $\mathrm{CH}-1379$ & 3.40 & 1.85 & 1.84 & - & - & - & - & - & - \\
\hline $\mathrm{CH}-1382$ & 3.70 & 1.95 & 1.98 & - & - & - & - & - & - \\
\hline $\mathrm{CH}-1383$ & 3.80 & 1.80 & 1.92 & - & - & - & - & - & - \\
\hline $\mathrm{CH}-1387$ & 3.70 & 1.80 & 1.90 & - & - & - & - & - & - \\
\hline CH- 1389 & 3.95 & 1.90 & 2.02 & - & - & - & - & - & - \\
\hline CH- 1390 & 3.65 & 1.70 & 1.83 & - & - & - & - & - & - \\
\hline CH-1392 & 3.50 & 1.70 & 1.78 & - & - & - & - & - & - \\
\hline $\mathrm{CH}-1394$ & 3.75 & 1.80 & 1.91 & - & - & - & - & - & - \\
\hline CH- 1395 & 3.85 & 1.80 & 1.94 & - & - & - & - & - & - \\
\hline $\mathrm{CH}-1399$ & 3.75 & 1.70 & 1.85 & - & - & - & - & - & - \\
\hline $\mathrm{CH}-1407$ & 3.65 & 1.80 & 1.88 & - & - & - & - & - & - \\
\hline $\mathrm{CH}-1408$ & 3.90 & 2.00 & 2.05 & - & - & - & - & - & - \\
\hline CH-1409 & 4.05 & 2.00 & 2.09 & - & - & - & - & - & - \\
\hline $\mathrm{CH}-1412$ & 3.90 & 1.80 & 1.95 & - & - & - & - & - & - \\
\hline $\mathrm{CH}-1414$ & - & - & - & 2.50 & 1.70 & 1.45 & - & - & - \\
\hline $\mathrm{CH}-1415$ & - & - & - & 2.60 & 1.85 & 1.57 & - & - & - \\
\hline $\mathrm{CH}-1416$ & 3.75 & 1.70 & 1.85 & - & - & - & - & - & - \\
\hline $\mathrm{CH}-1417$ & $\times$ & 1.90 & - & - & - & - & - & - & - \\
\hline CH-1419 & $\times$ & 2.00 & - & - & - & - & - & - & - \\
\hline $\mathrm{CH}-1420$ & 3.70 & 1.70 & 1.84 & - & - & - & - & - & - \\
\hline $\mathrm{CH}-1425$ & - & - & - & 2.50 & 1.70 & 1.47 & - & - & - \\
\hline $\mathrm{CH}-1427$ & - & - & - & 2.50 & 1.80 & 1.50 & - & - & - \\
\hline $\mathrm{CH}-1429$ & - & - & - & 2.70 & 1.80 & 1.58 & - & - & - \\
\hline $\mathrm{CH}-1432$ & - & - & - & 2.50 & 1.75 & 1.48 & - & - & - \\
\hline $\mathrm{CH}-1473$ & 3.50 & 1.80 & 1.84 & - & - & - & - & - & - \\
\hline CH-1479 & $x$ & 2.00 & - & - & - & - & - & - & - \\
\hline $\mathrm{CH}-1482$ & $x$ & 1.80 & - & - & - & - & - & - & - \\
\hline \multicolumn{10}{|l|}{ Upper teeth } \\
\hline Specimen & M1L & M1W & $\ln$ & M2L & $\mathbf{M} 2 \mathbf{W}$ & $\ln$ & & & \\
\hline $\mathrm{CH}-1326$ & - & - & - & 2.20 & 2.40 & 1.66 & & & \\
\hline $\mathrm{CH}-1440$ & 2.70 & 2.50 & 1.91 & 2.00 & 2.45 & 1.59 & & & \\
\hline CH-1449 & 2.50 & 2.50 & 1.83 & - & - & - & & & \\
\hline $\mathrm{CH}-1453$ & $\begin{array}{l}2.70 \\
2.60\end{array}$ & $\begin{array}{l}2.70 \\
2.60\end{array}$ & $\begin{array}{l}1.99 \\
1.91\end{array}$ & $\overline{-}$ & $\overline{-}$ & $\overline{-}$ & & & \\
\hline $\begin{array}{l}\mathrm{CH}-1454 \\
\mathrm{CH}-1455\end{array}$ & $\begin{array}{l}2.60 \\
2.70\end{array}$ & $\begin{array}{l}2.60 \\
2.70\end{array}$ & $\begin{array}{l}1.91 \\
1.99\end{array}$ & - & - & $\overline{-}$ & & & \\
\hline CH-1456 & 2.70 & 2.70 & 1.99 & - & - & - & & & \\
\hline CH-1458 & - & - & - & 2.20 & 2.60 & 1.74 & & & \\
\hline CH-1461 & 2.65 & 2.70 & 1.98 & - & - & - & & & \\
\hline $\mathrm{CH}-1463$ & 2.55 & 2.60 & 1.89 & - & - & - & & & \\
\hline
\end{tabular}



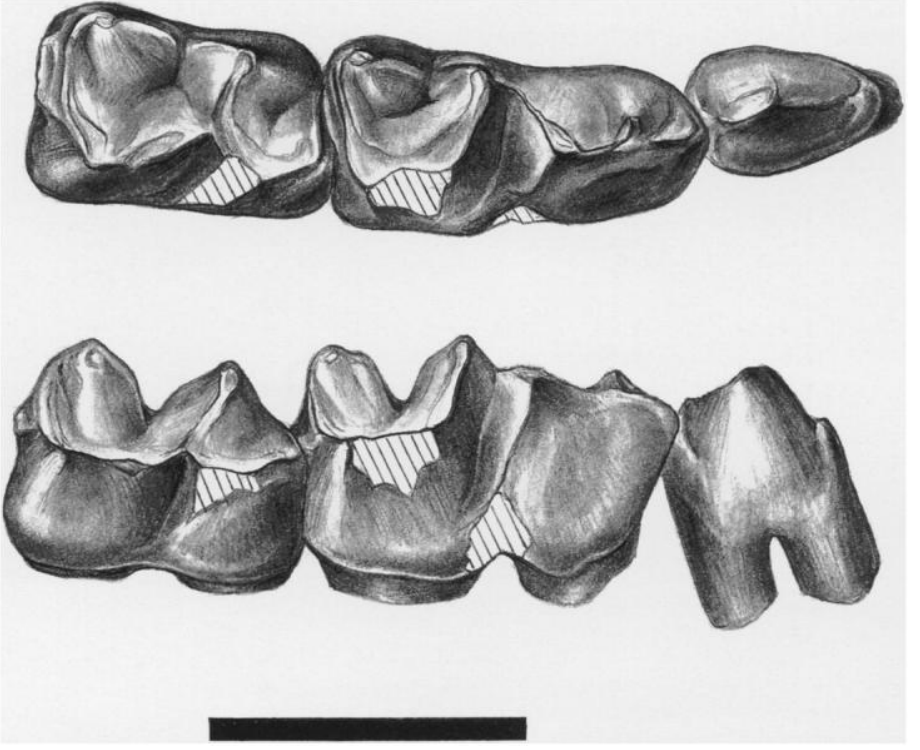

FIGURE 17-Palaeothentes migueli n. sp. (Palaeothentinae); MACN CH1338 (type), right p3-m2, in occlusal (top) and labial (bottom) aspects $($ bar $=2.0 \mathrm{~mm})$.
Hypodigm. - The type specimen and the following MACN numbers: $\mathrm{CH}-1327$, left p3-m1; $\mathrm{CH}-1335$, right $\mathrm{m} 2-4$; $\mathrm{CH}-$ 1342, right $\mathrm{m} 2-3$; $\mathrm{CH}-1344$, right $\mathrm{m} 2-3$; $\mathrm{CH}-1348$, right $\mathrm{m} 1$; $\mathrm{CH}-1362$, right $\mathrm{ml} ; \mathrm{CH}-1364$, right $\mathrm{ml} ; \mathrm{CH}-1372$, left $\mathrm{p} 3-\mathrm{m} 1$; CH-1375, left m2-3; CH-1376, left m1-2; CH-1378, left m12 ; $\mathrm{CH}-1381$, right $\mathrm{ml}-2$; $\mathrm{CH}-1385$, right $\mathrm{ml}$; $\mathrm{CH}-1386$, left m2-3; CH-1388, right m1-2; CH-1396, left m2-3; CH-1397, left m 1; CH-1400, right m l-2; CH-1401, left m2-3; CH-1406, left p3-m1; CH-1413, right m2; CH-1421, left m2; $\mathrm{CH}-1422$, left $\mathrm{m} 2 ; \mathrm{CH}-1423$, left $\mathrm{m} 2-3 ; \mathrm{CH}-1426$, left $\mathrm{m} 2 ; \mathrm{CH}-1428$, right $\mathrm{m} 2$; $\mathrm{CH}-1431$, right $\mathrm{m} 2$; $\mathrm{CH}-1433$, left $\mathrm{m} 1 ; \mathrm{CH}-1434$, left $\mathrm{m} 2$; $\mathrm{CH}-1435$, left $\mathrm{ml}$; $\mathrm{CH}-1437$, left m2; CH-1438, left m2-3; CH1459, right M1; $\mathrm{CH}-1460$, right M1; CH-1462, right M1 (Figure 25.1); CH-1464, left p3-m2.

Distribution. - All specimens are from La Cantera in the upper part of the late Colhuéhuapian (latest Oligocene or earliest Miocene) Trelew Member of the Sarmiento Formation in the valley of the Río Chubut, near Gaiman, eastern part of Provincia del Chubut, Argentina (Fleagle and Bown, 1983).

Etymology.-For Miguel Fernando Soria, Argentine paleontologist who died of a tragic accident in 1990, in recognition of his contributions to the mammalian paleontology of Argentina.

Discussion. - Palaeothentes migueli is the third exceedingly diminutive palaeothentid known and the first from pre-Santa-

TABle 9-Specimen data for first three lower molars and first upper molar of Palaeothentes migueli $\mathrm{n}$. sp., from La Cantera in the Sarmiento Formation, Provincia del Chubut. $\ln =$ natural logarithm $(\mathrm{L} \times \mathrm{W})$ of molar; $x=$ broken tooth. Measurements in millimeters.

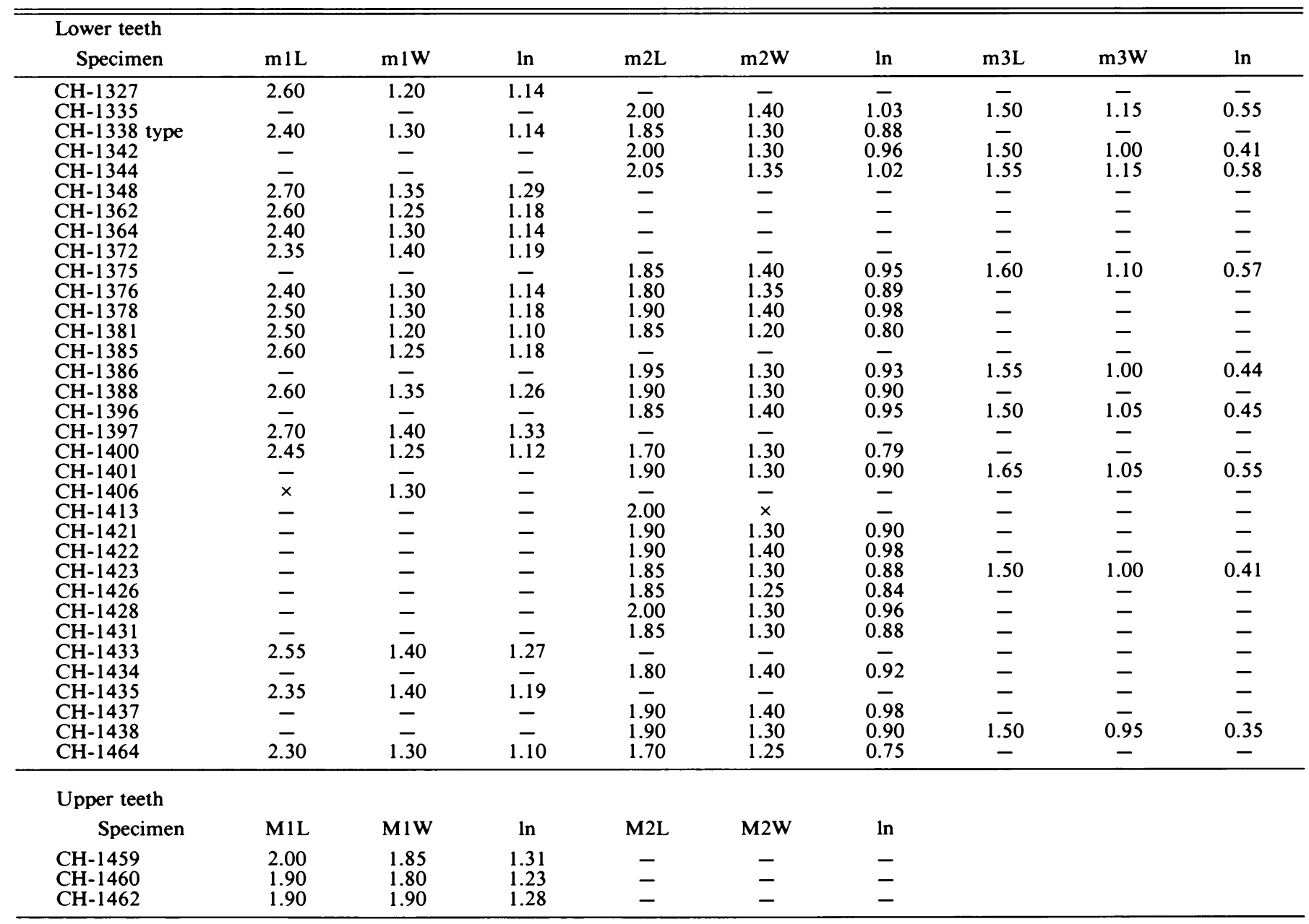


crucian rocks. The new species is approximately intermediate in size between the larger Palaeothentes minutus and the smaller $P$. pascuali, both of Santacrucian age, and is much smaller than all other palaeothentids. From the contemporary $P$. primus, $P$. migueli clearly differs in the longer and deeper paraconid valley and in having (like all other Palaeothentes) the $\mathrm{ml}$ cristid obliqua confluent with the metaconid. M1 of Palaeothentes migueli differs from that tooth in Palaeothentes marshalli, $P$. intermedius, $P$. lemoinei, and $P$. aratae in having: 1$)$ more trenchant cusps; 2) a protoconule; and 3 ) a postprotocone crista that is joined to the hypocone platform, not separated from it by a deep fissure). In Palaeothentes minutus and $P$. pascuali, the molar cusps are trenchant (only lower teeth are known for $P$. pascuali), but characters 2 and 3 above are as in other Palaeothentes.

Palaeothentes migueli is known only from La Cantera in the Trelew Member of the Sarmiento Formation, where it is almost equally as common as the larger Trelewthentes rothi (Acdestinae), but only half as common as the larger Palaeothentes marshalli. The new species was a very small palaeothentid of uncertain dietary habits. See Figures 28-31 for molar area distributions of Palaeothentes migueli relative to those of other Deseadan-Santacrucian Palaeothentidae.

PALAeOTHENTES MiNutus Ameghino, 1887 Frontispiece 1, Figures 18, 24.3

Synonyms. -See Marshall (1980, p. 55).

Holotype.-MACN 15, right mandibular ramus with p3-m4 (Marshall, 1980, fig. 18).

Revised diagnosis. - Small palaeothentine; larger than Palaeothentes pascuali and considerably smaller than Palaeothentes primus, $P$. marshalli, $P$. intermedius, $P$. lemoinei, $P$. boliviensis, and $P$. aratae; slightly larger than Colhuéhuapian $P$. migueli. Lower third premolar equal height or taller than paraconid of $\mathrm{m} 1$, in contrast to most $P$. migueli and all $P$. intermedius. Lower molars narrow as in $P$. pascuali, narrower than in other species, and upper and lower molars with more trenchant cusps than in other Palaeothentes excepting $P$. pascuali. First lower molar with type 2 trigonid structure predominant $(88 \%, N=23)$, three specimens $(11.5 \%)$ with type 1 . Paraconid of $\mathrm{ml}$ distinctly twinned but with fissure extending less posteriorly than in $\mathrm{Pa}$ laeothentes marshalli or P. migueli (about as in Palaeothentes aratae). Mean size ratio of $\mathrm{m} 3 / \mathrm{m} 2$ greater than in all other Palaeothentes excepting $P$. pascuali and $P$. marshalli. See Table 10 for measurements.

Hypodigm. - The type specimen; specimens listed by Marshall (1980, p. 55, 62-64, 67, 68); MNHN 531-533, 536 (Marshall, 1990); and the new material listed below.

New material. - MACN numbers SC-534, miscellaneous teeth SC-547, left p3-m2; SC-548, left m2-3; SC-623, left m2-3; SC674 , left $\mathrm{m} 2$; SC-678, right $\mathrm{m} 2$ (talonid)-m 3 ; SC-734, right $\mathrm{m} 1-$ 2; SC-735, left m2-3; SC-819, left m2; SC-1028, left m2; SC1029 , right $\mathrm{m} 3$; SC-1030, right $\mathrm{m} 3$; SC-1031, right $\mathrm{m} 2-3$; SC-1032, left $\mathrm{m} 1$; SC-1036A, right $\mathrm{m} 2$; SC-1036B, right $\mathrm{m} 2$; SC-1037, right $\mathrm{m} 1-2$; SC-1041, left $\mathrm{m} 2-3$; SC-1043, left $\mathrm{m} 3$; SC-1044, left m3; SC-1095, left m2; SC-1138, right m2; SC1144 , right $\mathrm{m} 1$ (talonid)-m 2 ; SC-1 147, right $\mathrm{m} 1$; SC-1 150, right p3-m4 (Figure 18); SC-1202, right p3-m1; SC-1204, left p3m2; SC-1209, right p3-m 1; SC-1210, right m 1-4; SC-1213, left p3 (part), m1-2, m3 (trigonid); SC-1219, left m1-3; SC-1220, left $\mathrm{ml}$ (talonid)-m4; SC-1223, right $\mathrm{ml} 1-3$; SC-1226, right $\mathrm{i}$, p3-m 1; SC-1228, left m2-4; SC-1231, left m 1-2; SC-1232, left $\mathrm{m} 2$; SC-1257, left $\mathrm{ml-2}$; SC-1271, left m2; SC-1283, right p3$\mathrm{m} 2$; SC-1284, : ight $\mathrm{m} 2-4$; SC-1285, left $\mathrm{m} 1$ (talonid)-m2; SC1286, left $\mathrm{m} 1-2$; SC-1287, right $\mathrm{m} 2$; SC-1289, right $\mathrm{M} 1$; SC1298 , right $\mathrm{m} 1-2$; SC-1300, left $\mathrm{m} 3$; SC-1313, right $\mathrm{p} 3-\mathrm{m} 3$; SC-

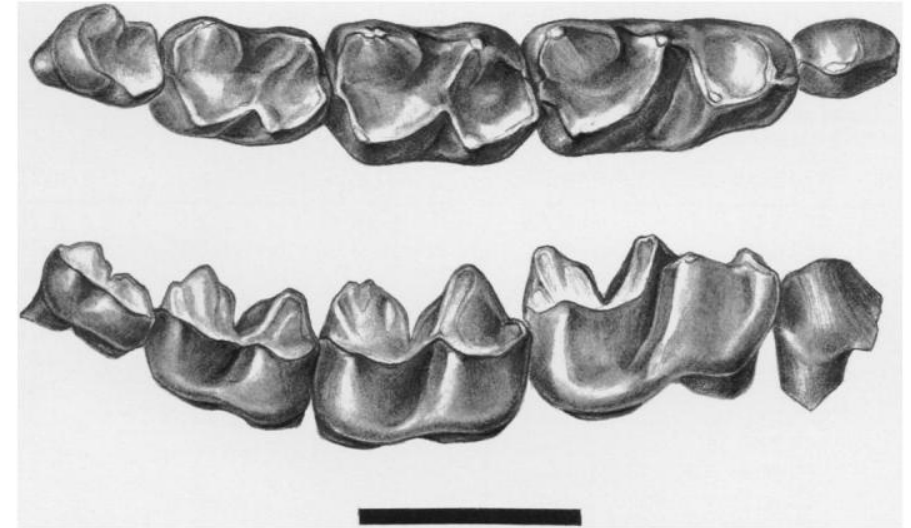

FIGURE 18-Palaeothentes minutus Ameghino (Palaeothentinae); MACN SC-1 150, right p3-m4, in occlusal (top) and labial (bottom) aspects $(\mathrm{bar}=2.0 \mathrm{~mm})$.

1322, right $\mathrm{m} 3$; SC-1328, right $\mathrm{m} 2-3$; SC-1329, right $\mathrm{ml} 1-3$; SC-1333, left p3-m2; SC-1338, left m2-3; SC-1350, right m23; SC-1351, left m2-3; SC-1352, left m2; SC-1353, left M1; SC1364, left $\mathrm{m} 3-4$; SC-1365, left $\mathrm{ml-3}$; SC-1377, left m3; SC1381, left m2-4; SC-1464, right p3-m3; SC-1470, left m2-3; SC-1812, right $\mathrm{m} 2-3$; SC-1813, left $\mathrm{m} 2-3$; SC-2885, left $\mathrm{m} 2$; SC-2891, left m1-4; SC-2892, left m2-4; SC-2913, left p3-m 1; SC-2915, right $\mathrm{m} 2-4$; SC-2923, left $\mathrm{m} 3$; SC-2934, left $\mathrm{m} 1-2$; SC-2935, three m1; SC-2938, right p3; SC-2940, right m1-2; SC-2948, right m2; SC-2950, left m2-4; SC-2951, right M1-3; SC-2952, right m2; SC-2961, left m2; SC-2969, right m2-4; SC2978, left m2-3; SC-2980, right m3-4; SC-2983, left m 1; SC2985, left $\mathrm{m} 1$; SC-2986, right p3; SC-3011, left $\mathrm{m} 1-4$; SC-3016, left m2-3; SC-3018, right M1; SC-3019, right p3; SC-3020, right p3 and $\mathrm{m} 2$; SC-3021, right p3-m2; SC-3022, right p3-m3; SC3030 , right $\mathrm{m} 2$; SC-3047, right $\mathrm{m} 2-4$; SC-3049, left p3-m3; SC3050, left m2-3; SC-3051, left m2-4; SC-3052, left m2-3; SC3053, right $\mathrm{m} 1-2$; SC-3055, right $\mathrm{m} 1-2$; SC-3058, right $\mathrm{m} 2-3$; SC-3059, left p3; SC-3060, right m1-2; SC-3061, left m 1; SC3062, right $\mathrm{m} 2-4$; SC-3063, left p3-m2; SC-3064, left m2-3; SC-3065, right p3-m4; SC-3066, right p3-m2; SC-3076, left p3-m1; SC-3077, left m1-4; SC-3078, right m3-4; SC-3079, left $\mathrm{m} 2-3$; SC-3081, left $\mathrm{m} 2-3$; SC-3082, right $\mathrm{m} 2-3$; SC-3147, left m1-3; SC-3148, right m3; SC-3149, left p3-m 1; SC-3164, left $\mathrm{m} 2-3$; SC-3166, left $\mathrm{m} 2$; SC-3167, right $\mathrm{m} 1$; SC-3170, right p3; SC-3172, left M1; SC-3174, right m2-3; SC-3178, left p3$\mathrm{ml}$; SC-3179, right $\mathrm{ml} 1-3$; SC-3180, left $\mathrm{ml-2}$; SC-3188, right p3 and $\mathrm{m} 2$; SC-3194, right $\mathrm{m} 1-2$; SC-3199, right M1; SC-3206, left $\mathrm{m} 2$; SC-3208, right $\mathrm{m} 3-4$; SC-3209, right $\mathrm{m} 2-4$; SC-3215, left p3-m 1; SC-3216, left m2-3; SC-3222, right M1; SC-3224, right $\mathrm{m} 1$; SC-3227, right $\mathrm{m} 2$; SC-3228, left p3-m2; SC-3239, left $\mathrm{m} 2-3$; SC-3246, right $\mathrm{p} 3$ and $\mathrm{m} 2-3$; SC-3247, right $\mathrm{m} 2-3$; SC-3251, left $\mathrm{m} 2-3$; SC-3253, right M2; SC-3255, left $\mathrm{m} 2-3$; SC-3256, left m2-3; SC-3257, right $\mathrm{m} 2-4$; SC-3258, right M1 and $\mathrm{M} 2$; SC-3264, right $\mathrm{M} 1$; SC-3268, right $\mathrm{ml}$; SC-3274, right $\mathrm{m} 1$; SC-3275, right $\mathrm{m} 2-3$; SC-3276, left M1; SC-3284, left M13; SC-3286, right M1-4 (Figure 24.3); SC-3288, left p3; SC3294, right $\mathrm{m} 1$; SC-3357, right $\mathrm{m} 3$; SC-3403, left $\mathrm{m} 1-2$; SC3404, right $\mathrm{ml-2}$; SC-3415a, left m1-3; SC-3417, left M1-2.

Localities of new material. - The following specimens are from the Pinturas Formation in the upper valley of the Rio Pinturas, northwest Provincia de Santa Cruz: 1) Estancia Los Toldos (cerca del casco) (MACN SC-534); 2) Cerro de los Monos (MACN SC numbers 547, 548, 623); 3) Estancia Ana Maria (Loma de las Ranas) (MACN SC numbers 734, 735); 4) Loma de la Lluvia (MACN SC numbers 674, 678, 3264, 3276); 5) Portzuelo Su- 
TABLE 10-Specimen data for first three lower molars and first two upper molars of Palaeothentes minutus Ameghino from various localities in the Pinturas and Santa Cruz Formations, Provincia de Santa Cruz. $\ln =$ natural logarithm $(\mathrm{L} \times \mathrm{W})$ of molar; $x=$ broken tooth. Measurements in millimeters.

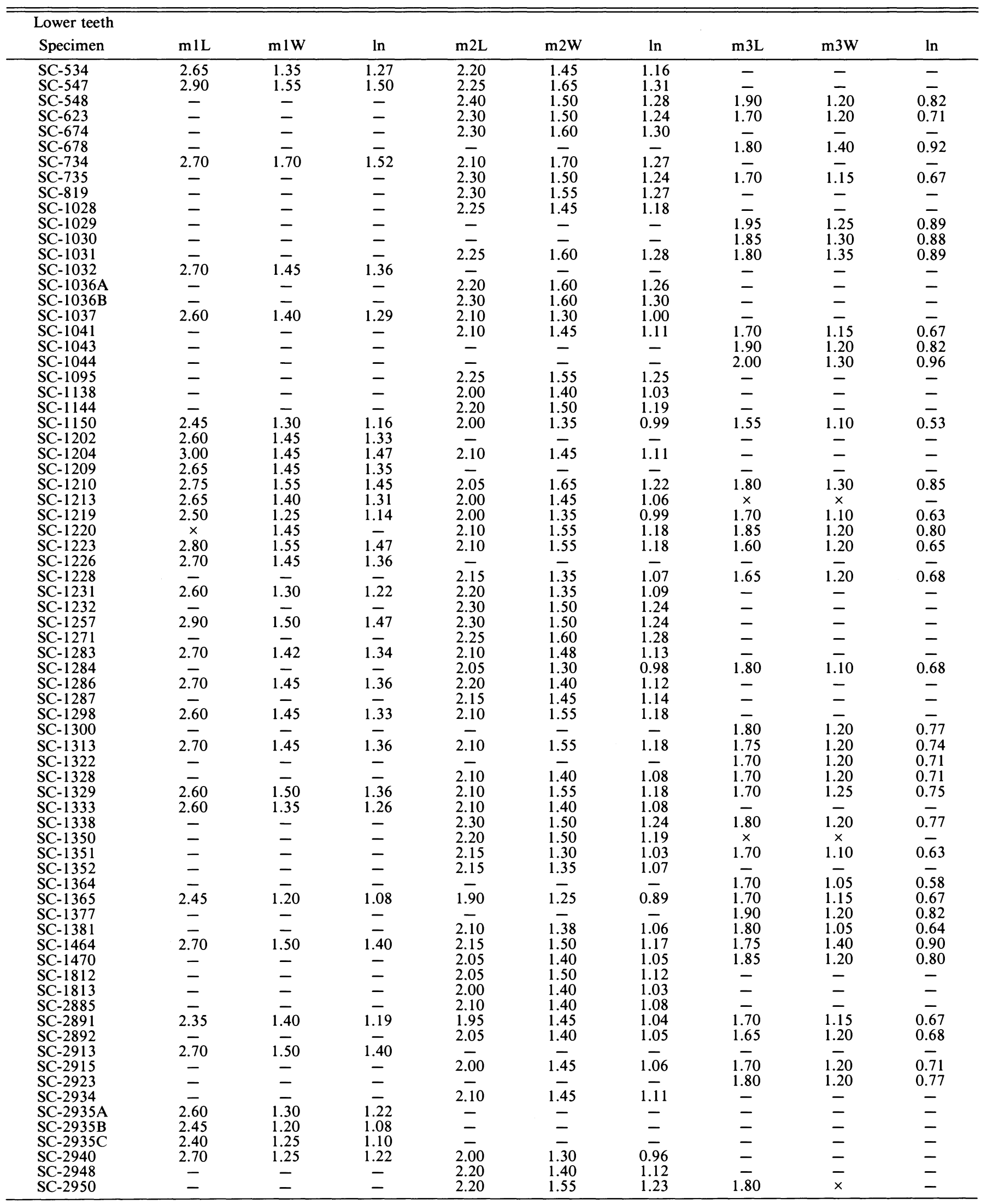


TABLE $10-$ Continued.

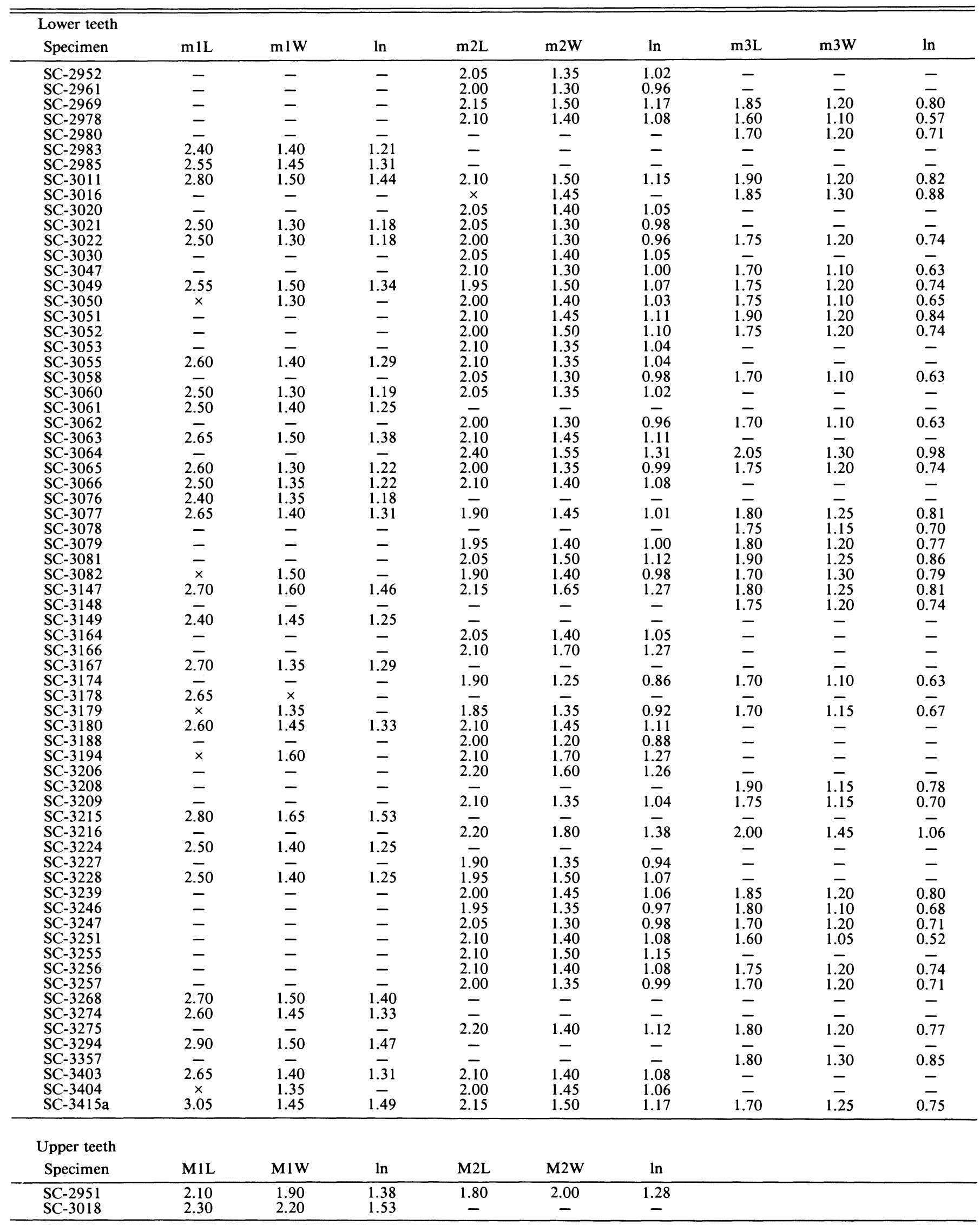


TABLE $10-$ Continued.

\begin{tabular}{lcccccc}
\hline \hline $\begin{array}{c}\text { Upper teeth } \\
\text { Specimen }\end{array}$ & $\mathrm{m} 1 \mathrm{~L}$ & $\mathrm{~m} 1 \mathrm{~W}$ & $\mathrm{ln}$ & $\mathrm{m} 2 \mathrm{~L}$ & $\mathrm{~m} 2 \mathrm{~W}$ & $\ln$ \\
\hline SC-3172 & 2.20 & 1.90 & 1.43 & - & - & - \\
SC-3222 & 2.30 & 2.05 & 1.55 & $\overline{-}$ & $\overline{-}$ & $\overline{-}$ \\
SC-3253 & $\overline{-}$ & $\overline{-}$ & $\overline{-}$ & 1.80 & 2.05 & 1.31 \\
SC-3258 & 2.10 & 2.00 & 1.44 & 1.80 & 1.85 & 1.20 \\
SC-3264 & 2.30 & 2.00 & 1.53 & $\overline{-}$ & $\overline{1.85}$ & 1.17 \\
SC-3284 & 2.20 & 1.80 & 1.38 & 1.75 & 1.00 & 1.28 \\
SC-3286 & 2.15 & 1.85 & 1.38 & 1.80 & 2.00 & 1.31 \\
SC-3417 & 2.40 & 2.00 & 1.57 & 1.90 & 1.95 & \\
\hline
\end{tabular}

mich Sur (MACN SC numbers 819, 904, 1028-1032, 1036A, 1036B, 1037, 1041, 1043, 1044, 1095, 3268, 3274, 3275); 6) Estancia El Carmen (MACN SC-3215 (3m above sequence of mature paleosols), SC-3216 (in tuff below upper sequence), SC3222 (lower sequence below zone of mature paleosols). The following specimens are from exposures on the south bank of the Río Chalia (Provincia de Santa Cruz) at: 1) Estancia Mank Aike (MACN SC-3018, 3019); 2) estaca 4 (MACN SC numbers 3403, 3404, 3417); 3) estaca 5 (MACN SC-3415a). The following specimens are from the Santa Cruz Formation (Provincia de Santa Cruz) at Monte León: 1) estaca 1 (MACN SC numbers 2885, 3178, 3179, 3180, 3288); 2) estaca 6 (MACN SC-1313; 3) estaca 142 (MACN SC numbers 1202, 1204, 1209, 1210, $1213,1219,1220,1223,1226,1228,1231,1232,1464,1470$, $2938,2940,2948,2950,2951,2952,3081,3082)$. The following specimens are from the Santa Cruz Formation at Monte Observación (Estancia Cañadon de las Vacas, Provincia de Santa Cruz): 1) estaca 7 (MACN SC numbers 3011, 3016, 3020-3022, 3030, 3047, 3049, 3050-3053, 3055, 3058-3066, 3076-3079, 3284, 3286, 3357; 2) estaca 12 (MACN SC numbers 3164, 3166 , 3167); 3) estaca 15 (MACN SC-1813); 4) estaca 17 (MACN SC2961); 5) estaca 19 (MACN SC numbers 1812, 3239, 3294); 6) estaca 25 (MACN SC numbers 3147-3149); 7) estaca 29 (MACN SC numbers $1144,1364,1365,3255-3258$ ); 8) estaca 30 (MACN SC-1257); 9) estaca 32 (MACN SC numbers 3206, 3208, 3209); 10) estaca 40 (MACN SC-1377); 11) estaca 44 (MACN SC1271); 12) estaca 54 (MACN SC numbers 1283-1287, 1289); 13) estaca 56 (MACN SC-1300); 14) estaca 59 (MACN SC1298); 15) estaca 61 (MACN SC-3194); 16) estaca 63 (MACN SC numbers 3224, 3227, 3228); 17) estaca 68 (MACN SC-3199); 18) estaca 69 (MACN SC numbers 1322, 1328, 1329, 1333, 1338); 19) estaca 101 (MACN SC-1347); 20) estaca 106 (MACN SC numbers 1350-1353); 21) estaca 108 (MACN SC numbers $1150,1381,3246) ; 22$ ) estaca 110 (MACN SC-3188); 23) estaca 120 (MACN SC-3247); 24) estaca 144 (MACN SC-1138); 25) estaca 145 (MACN SC-1147); 26) estaca 200 (MACN SC numbers 3251, 3253); 27) estaca 203 (MACN SC numbers 2969, 2978, 2980, 2983, 2985, 2986); 28) estaca 204 (MACN SC numbers 2891, 2892, 3170, 3172, 3174); 29) estaca 206 (MACN SC numbers 2913, 2915, 2923, 2934, 2935).

In addition to the above Argentine localities, specimens of Palaeothentes minutus are also known from Killik Aike, La Cueva, Río Gallegos, "Santa Cruz," Sehuen, and "South side of the Río Santa Cruz, 60 miles below Lago Argentino."

Distribution. - Santacrucian (early-middle Miocene) Pinturas and Santa Cruz Formations, Provincia de Santa Cruz, Argentina (Santacrucian temporal values $=8.0-96.2$ ); Alto Río Cisnes, Chile.

Discussion. - Palaeothentes minutus is one of the smallest palaeothentine caenolestoids and, together with Acdestis oweni, is one of the two most abundant (165 new specimens are documented here, and more than treble what was known in 1980).
The species is present at nearly all significant localities of Santacrucian age and is the most abundant palaeothentid at many. Contemporaneous $P$. pascuali possesses very narrow, trenchant molars in common with $P$. minutus but has a much shallower ramus and teeth that average 20 percent smaller size.

Teeth of Palaeothentes minutus are somewhat conservative in morphology and possess remarkably little correlatable variability considering the large number of localities involved and temporal differences between samples. Some specimens of $\mathrm{m} 1$ are quite narrow and appear rather drawn-out (e.g., SC-2940); however, this features does not appear to correlate well with either locality of origin or presumed age. Palaeothentes minutus $\mathrm{m} 1$ and $\mathrm{m} 2$ evince a tendency to decrease slightly in mean size through time (Figures 30, 31, 33, 34), all teeth retaining, however, their more or less uniform morphology. In the mean of the ratio of the area of $\mathrm{m} 3$ to that of $\mathrm{m} 2$, Palaeothentes minutus possesses a greater value than any Palaeothentes, excepting $P$. marshalli and $P$. pascuali, and the greatest variability in that character of any palaeothentid.

Palaeothentes minutus was a small faunivorous palaeothentid, with a body weight of approximately 75 grams (Strait et al., 1990, and unpublished data). See Figures 28-31 for molar area distributions of Palaeothentes minutus relative to those of other Deseadan-Santacrucian Palaeothentidae.

\section{PALAEOTHeNTES PASCUALI $n$. sp. Figure 19}

Holotype.-MACN SC-1293 (Figure 19), left mandibular ramus with p3-m3.

Diagnosis. -Smallest known species of Palaeothentes; m1-3 length about 14 percent smaller than in Palaeothentes migueli and about 20 percent smaller than in Palaeothentes minutus. First lower molar with type 3 trigonid structure (four examples). Mean size ratio of $\mathrm{m} 3 / \mathrm{m} 2$ considerably greater than in any other palaeothentid excepting Trelewthentes rothi and, possibly, Pilchenia lucina. See Table 7 for measurements.

Hypodigm. - The type specimen and MACN numbers SC2939, right $\mathrm{ml-3}$; SC-2945, right p1-m3; SC-3057, left m2-3; SC-3067, right $\mathrm{ml}-4$; SC-3148, right $\mathrm{m} 2$; possibly MACN SC3296, right $\mathrm{m} 1$.

Localities of new material. - Santa Cruz Formation, at: Monte León estaca 142 (MACN SC numbers 2939, 2945). Santa Cruz Formation, Monte Observación (Estancia Cañadon de las Vacas, Provincia de Santa Cruz), at: 1) estaca 7 (MACN SC numbers 3057, 3067); 2) estaca 19 (MACN SC-3296); 3) estaca 25 (MACN SC-3148); 4) estaca 54 (MACN SC-1293; type).

Distribution.-Santacrucian (early-middle Miocene) Santa Cruz Formation, coastal Provincia de Santa Cruz, Argentina (Santacrucian temporal values $=80.1-91.1$ ).

Etymology. - For Rosendo Pascual, in recognition of his many contributions to the vertebrate paleontology of South America.

Discussion. - Palaeothentes pascuali is distinctive in being the 


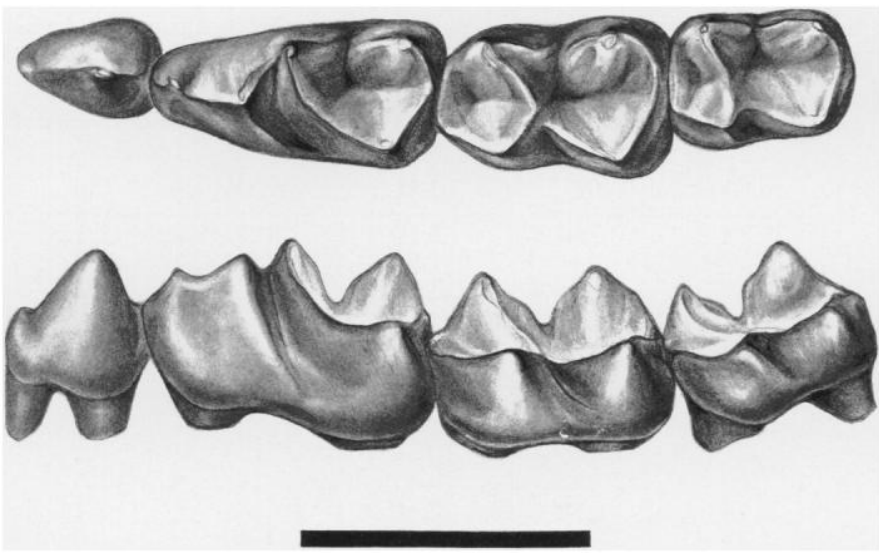

FIGURE 19-Palaeothentes pascuali n. sp. (Palaeothentinae); MACN SC1293 (type), left p3-m3, in occlusal (top) and labial (bottom) aspects $(\mathrm{bar}=2.0 \mathrm{~mm})$

smallest known member of the Palaeothentidae -20 percent smaller in mean tooth size than its also very small contemporary, $P$. minutus, and 40 percent smaller than coeval $P$. intermedius. Though closest in size to Colhuéhuapian Palaeothentes migueli, $P$. pascuali clearly differs from that species in its taller p3, narrower, more trenchant lower molars, type 3 trigonid structure on $\mathrm{ml}$, and more restricted valley separating the twinned $\mathrm{m} 1$ paraconid.

Only six specimens are positively referable to $P$. pascuali. MACN SC-3296, a right $\mathrm{ml}$, lies at the base of the size range for $\mathrm{m} 1$ in Palaeothentes minutus and possibly belongs in that taxon. MACN SC-2945 and 3067 likewise possess $\mathrm{m} 1$ in the lower part of the size range for $P$. minutus but have $\mathrm{m} 2$ 's that are clearly too small for assignment to the latter taxon (Figures 29,43 ). The possession of type 3 trigonid structure is unusual for palaeothentines and is quite rare in Palaeothentidae.

Palaeothentes pascuali was the smallest palaeothentid, was probably faunivorous, and had a body weight of approximately 50 grams (Strait et al., 1990, and unpublished data). See Figures 28-31 for molar area distributions of teeth of Palaeothentes pascuali with respect to those of other Deseadan-Santacrucian Palaeothentidae.

Palaeothentes INTERMedius Ameghino, 1887 Figures 20, 24.4

Synonyms. - See Marshall (1980, p. 72).

Holotype.-MACN 2, right mandibular ramus with p3-m3.

Revised diagnosis.-Medium-sized palaeothentine; molars about 28 percent larger than in $P$. minutus and $25-35$ percent smaller than in $P$. lemoinei; about the size of Colhuéhuapian $\boldsymbol{P}$. primus. Differs from $\boldsymbol{P}$. primus in having shorter $\mathrm{p} 3$, larger $\mathrm{m} 3 \mathrm{area} / \mathrm{m}^{2}$ area, more transverse protocristid, and cristid obliqua confluent with metaconid. Molars broader and less trenchant than in $P$. pascuali and $P$. minutus. Lower third premolar smaller than in $P$. lemoinei and p3 crown slightly lower than $\mathrm{m} 1$ trigonid (perhaps slightly more so, and more commonly so, than in $P$. marshalli). Lower first molar with types 1 or 2 trigonid structure (each with 50 percent representation); $\mathrm{m} 2$ with strong vespiform constricition between trigonid and talonid and mean of $\mathrm{m} 3 / \mathrm{m} 2$ area ratio small, larger than that in $P$. aratae, and smaller than that in all other species of Palaeothentes. M1-2 less transverse and with longer talon than in $P$. aratae. See Table 11 for measurements.

Hypodigm. - The type specimen; the specimens listed by Marshall $(1980$, p. $73,74,76,77$, excepting the type specimen of
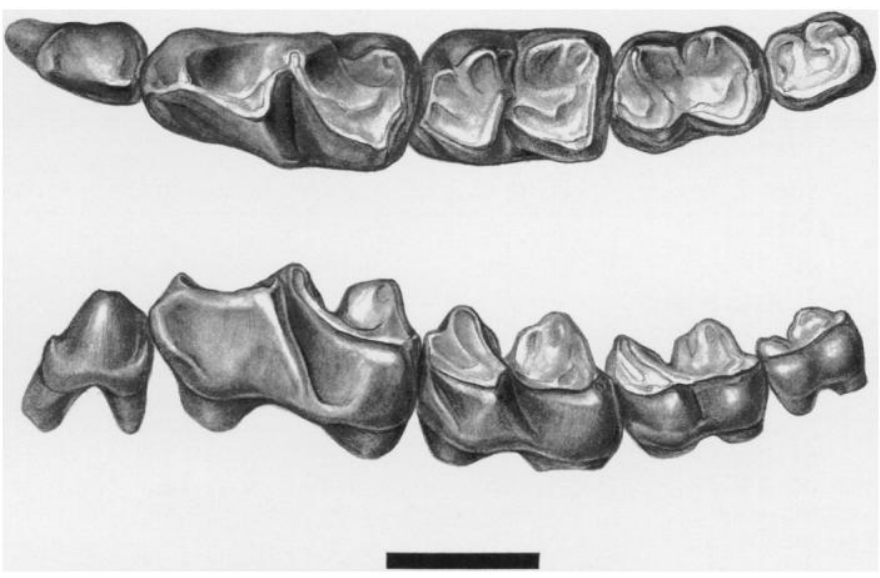

FIGURE 20-Palaeothentes intermedius Ameghino (Palaeothentinae); MACN SC-1215, left p3-m4, in occlusal (top) and labial (bottom) aspects (bar $=2.0 \mathrm{~mm})$.

Palaeothentes lepidus Ameghino); MNHN 530, MNHN 543 (Marshall, 1990); and the new material listed below.

New material. - MACN numbers SC-540, left m2-3; SC-732, left m2-3; SC-1 131, right m3-4; SC-1214, right m1-2; SC-1215, left p3-m4 (Figure 20); SC-1262, right M1; SC-1264, left m3; SC-1292, right M2; SC-1312, left m1-2; SC-1378, left M1-2; SC-1382, left $\mathrm{p} 3$ and $\mathrm{m} 2$; SC-1465, right $\mathrm{p} 3-\mathrm{m} \mathrm{1}$; SC-1467, right p3-m1; SC-1468, right $\mathrm{m} 2-4$; SC-1472, left $\mathrm{m} 2-3$; SC-1483, right $\mathrm{ml}$; SC-1484, left M1; SC-1630, right p3-m3; SC-1631, left m2-3; SC-2886, left p3; SC-2930, right M1; SC-2936, right m1-4; SC-2944, left m2-3; SC-2958, left p3-m4; SC-2965, left M2; SC-2970, left p3-m2; SC-2973, left p3; SC-2976, right M23; SC-2979, right $\mathrm{m} 2$; SC-2995, right P3-M4 (Figure 24.4); SC3001, left M1-3; SC-3012, left m2-3; SC-3013, left m2; SC3014, left m2-4; SC-3017, left m1-3; SC-3027, left M1; SC3039, left $\mathrm{m} 2$; SC-3080, left $\mathrm{m} 3-4$; SC-3082, left $\mathrm{ml-2}$; SC-3203, left m1-2; SC-3213, left p3-m3; SC-3223, left m1; SC-3225, right M1; SC-3237, left $\mathrm{m} 2$; SC-3280, right M1; SC3289 , right $\mathrm{m} 2$; SC-3291, left $\mathrm{m} 2$; SC-3295, left $\mathrm{m} 1$; SC-3390, left m3-4; SC-3398, right p3-m 3; SC-3401, left m3; SC-3405a, right $\mathrm{m} 2$; SC-3405c, right $\mathrm{p} 3$; SC-3414, left $\mathrm{m1-2}$; SC-3415b, left p3; SC-3416, right m3-4; SC-3419b, right M1.

Localities of new material. - The following specimens are from the Pinturas Formation in the upper valley of the Rio Pinturas (northwest Provincia de Santa Cruz): 1) Estancia Los Toldos (cerca del casco) (MACN SC-540); 2) Estancia El Carmen (MACN SC-3213; yellow tuff beneath upper sequence); 3) Estancia Ana Maria (MACN SC-1131). The following specimen is from rocks provisionally referred to the Pinturas Formation, south and east of the upper valley of the Rio Pinturas, Provincia de Santa Cruz, at Gobernador Gregores: MACN SC-732. The following specimens are from the Santa Cruz Formation in the valley of the Río Chalia, at: 1) estaca 1 (MACN SC-3390); 2) estaca 2 (MACN SC-3398); 3) estaca 4 (MACN SC numbers 3401, 3405a, 3405c); 4) estaca 5 (MACN SC numbers $3415 b, 3416,3419 b$ ). The following specimens are from the Santa Cruz Formation at Monte León (Provincia de Santa Cruz), at: 1) estaca 1 (MACN SC2886); 2) estaca 142 (MACN SC numbers 1214, 1215, 1465$1468,1472,1483,2936,2944,3080,3082)$; 3) Monte León, unknown locality (MACN SC-1484). The following specimens are from the Santa Cruz Formation at Monte Observación (Estancia Cañadon de las Vacas, Provincia de Santa Cruz): 1) estaca 7 (MACN SC numbers 2995, 3001, 3012-3014, 3017, 3027, 3039); 2) estaca 17 (MACN SC numbers 2958, 2965); 3) estaca 
TABLE 11-Specimen data for first three lower molars and first two upper molars of Palaeothentes intermedius Ameghino from various localities in the Pinturas and Santa Cruz Formations, Provinica de Santa Cruz. In $=$ natural logarithm $(\mathrm{L} \times \mathrm{W})$ of molar; $\times=$ broken tooth. Measurements in millimeters.

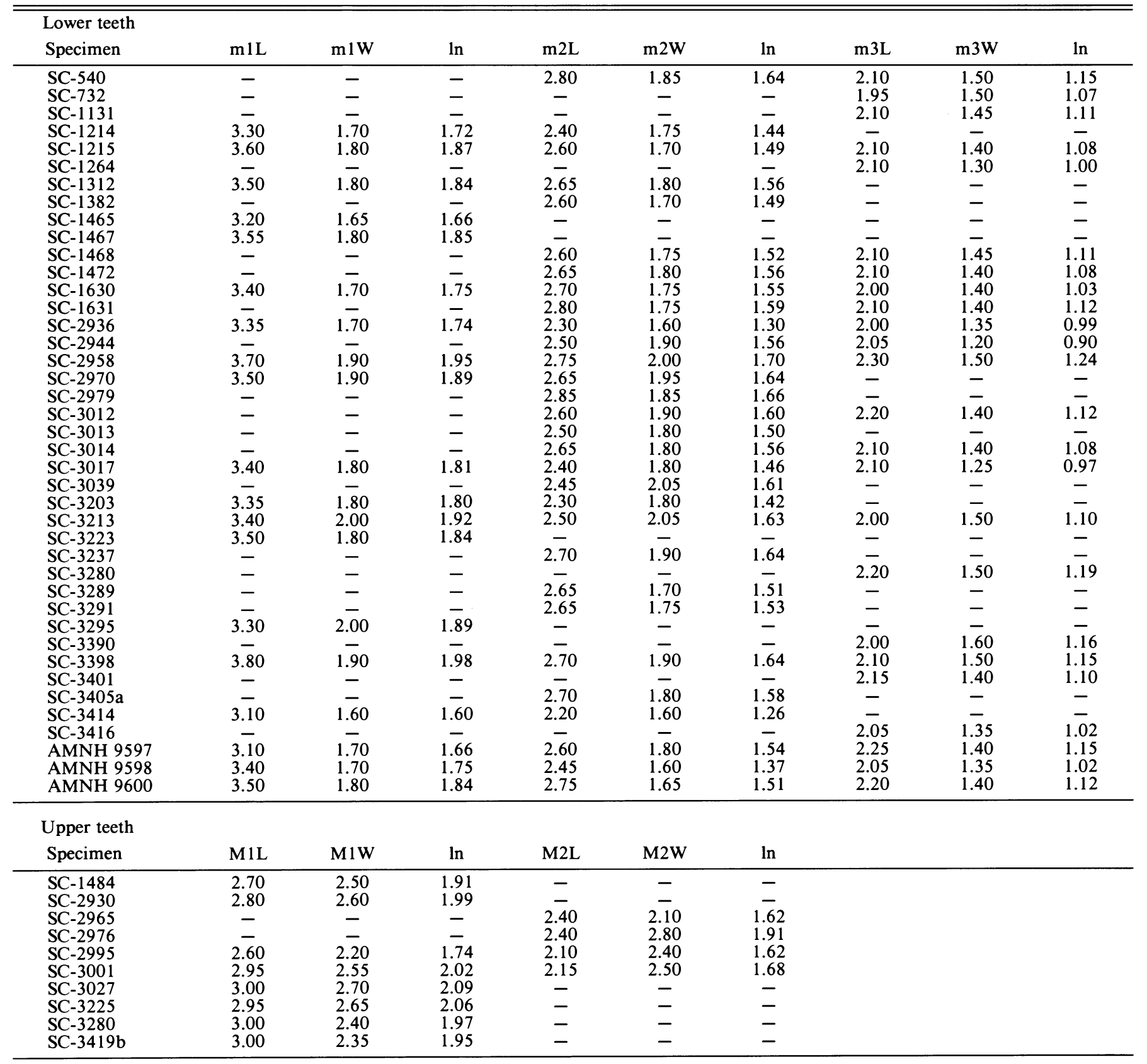

19 (MACN SC numbers 3237, 3295); 4) estaca 25? (MACN SC1312); 5) estaca 30 (MACN SC numbers 3289, 3291); 6) estaca 31 (MACN SC-1264); 7) estaca 32 (MACN SC-3203; 8) estaca 37 (MACN SC-1262); 9) estaca 40 (MACN SC-1378); 10) estaca 54 (MACN SC-1292); 11) estaca 63 (MACN SC numbers 3223, 3225); 12) estaca 69 (MACN SC-1334); 13) estaca 116 (MACN SC-1382); 14) estaca 203 (MACN SC numbers 2970, 2973, 2976, 2979); 15) estaca 206 (MACN SC numbers 2930, 3280); 16) no estaca number (MACN SC numbers 1630,1631 ).

In addition to the above Argentine localities, specimens of Palaeothentes intermedius are known from La Cueva, Rio Gallegos, "Santa Cruz," and Sehuen.
Distribution. - Santacrucian (early-middle Miocene) Pinturas and Santa Cruz Formations, Provincia de Santa Cruz, Argentina (Santacrucian temporal values $=60.0-91.1$ ); Alto Río Cisnes, Chile.

Discussion. - The 56 new specimens of Palaeothentes intermedius more than treble the sample of this scarce species, provide additional information on the upper dentition (hitherto known from but a single specimen), and cast doubt upon the shared similarities Marshall (1980; see discussion under $P$. primus) suggested that this species had with Colhuéhuapian $P$. primus. The vespiform constriction between the trigonid and talonid of $\mathrm{m} 2$ is better developed in $P$. intermedius than in $P$. marshalli 
and $\mathrm{M} 1-2$ are less transverse and possess a distinctively longer talon region than in the latter species. Moreover, the bifurcation of the $\mathrm{ml}$ paraconid is considerably more pronounced in $P$. marshulli than in $P$. intermedius. In the latter species, paraconid bifurcation is developed about the same as in $P$. primus; however, $P$. primus much more closely resembles $P$. aratae-the latter two species are collectively unique in primitively having a labial conjunction of the cristid obliqua with the postcristid.

Palaeothentes intermedius was a medium-sized faunivorous palaeothentid, with a body weight of approximately 100 grams (Strait et al., 1990, and unpublished data). See Figures 28-31 for molar area dimensions of Palaeothentes intermedius relative to those of other Deseadan-Santacrucian Palaeothentidae.

\section{Palaeothentes lemoinei Ameghino, 1887}

Figures 21, 25.2

Palaeothentes lemoinei AMEGHINO, 1887, p. 6.

Palaeothentes lobata MARSHALl AND PAScuAL, 1977, p. 111.

(See Marshall, 1980, p. 80 for complete listing.)

Holotype.-MACN 3, right mandibular ramus with $\mathrm{ml}-4$.

Revised diagnosis. - Large palaeothentine; lower molars about 25 percent larger than in Palaeothentes intermedius, 28-35 percent smaller than in $P$. aratae. Lower third premolar approximately equal in height to trigonid of $\mathrm{ml}$, taller with respect to $\mathrm{ml}$ than in $P$. marshalli or $P$. intermedius. First lower molar with types 1,2 and 3 trigonid structure $(44 \%, 12 \%$, and $44 \%$, respectively); $\mathrm{m} 2-3$ have a more sharply defined vespiform constriction between the trigonid and talonid than in $P$. aratae and the molars are more trenchant, but less so than in $P$. minutus or $P$. pascuali. Mean area ratio of $\mathrm{m} 3 / \mathrm{m} 2$ greater than in $P$. primus, $P$. intermedius, and $P$. aratae, smaller than in other Palaeothentes. Lower molars proportionately broader than in $P$. pascuali and $P$. minutus. As in Palaeothentes aratae, $P$. intermedius, and $P$. minutus, the fissure bifurcating the $\mathrm{m} 1$ paraconid is short and shallow but distinct, much shorter than in genus Pilchenia and shorter than in Palaeothentes marshalli and $P$. migueli. The anterior mure of the entoconid on m1-2 is generally better developed than in specimens of Palaeothentes intermedius (though variable in the latter species) and is organized approximately as in $P$. aratae, in which it partially closes the talonid notch. Upper molars distinctively triangular with protocone region sharp, very lingual, and prow-like in contrast to most other Palaeothentes species, but especially Palaeothentes intermedius (similar in this respect to some $P$. aratae). Hypocone area of M1 unexpanded lingually in contrast to Palaeothentes minutus, $P$. pascuali, $P$. intermedius, and $P$. aratae; about as in $P$. marshalli and Hondathentes cazador. M4 less reduced than in $P$. aratae. See Table 12 for measurements.

Hypodigm. - The type specimen; the specimens listed in Marshall (1980, p. 80, 83, 84); MNHN 529 and MNHN 546 (Marshall, 1990); and the new material listed below.

New material. - MACN numbers SC-1 140, left M2; SC- 1151 , right $\mathrm{ml}$; SC-1203, left $\mathrm{m} 2-3$; SC-1230, left m3-4; SC-1238, left $\mathrm{m} 1$; SC-1242, left m3; SC-1249, left p3-m3 (Figure 21); SC1252 , left $\mathrm{m} 1$; SC-1254, right M1; SC-1255, right p3-m3; SC1265, left p3; SC-1267, left m 1-3; SC-1270, left m2-3; SC-1281, right M1; SC-1290, left M1; SC-1294, right p3, m2-3; SC-1305, left $\mathrm{m} 1-3$; SC-1307, right $\mathrm{m} 3-4$; SC-1309, right $\mathrm{m} 1$ (talonid); SC-1311, left M2; SC-1319, right m3; SC-1356, right p3-m3 (damaged); SC-1369, left M2; SC-1374, right m2; SC-1462, left m2-4; SC-1463, right $\mathrm{m} 1-3$; SC-1471, left $\mathrm{ml}$; SC-1474, left $\mathrm{m} 1-3$; SC-1475, left $\mathrm{m} 1-2$; SC-1479, right $\mathrm{m} 2-3$; SC-1616, right M2; SC-1617, left m2-4; SC-1752, right M2-4; SC-2881, right p3-m 1; SC-2888, right $\mathrm{m} 2$; SC-2895, right $\mathrm{m} 3$; SC-2900, left p3; SC-2912, right m1; SC-2922, right M1-3; SC-2953, left m2-

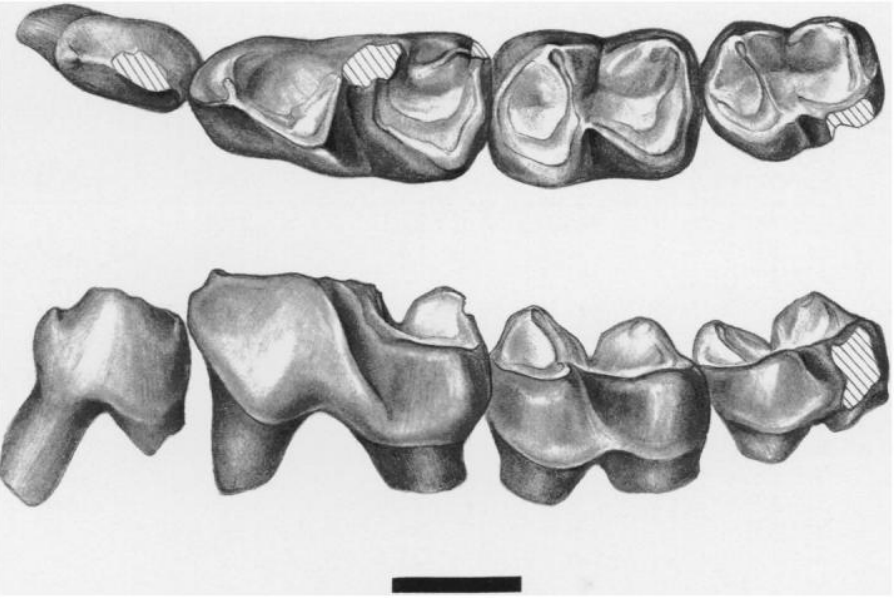

FIGURE 21-Palaeothentes lemoinei Ameghino (Palaeothentinae); MACN SC-1249, left p3-m3, in occlusal (top) and labial (bottom) aspects (bar $=2.0 \mathrm{~mm})$.

4; SC-2963, left m2-3; SC-2977, right M2; SC-2989, right $\mathrm{m} 1$; SC-3015, right $\mathrm{p} 3$ and $\mathrm{m} 2$; SC-3025, left i2-p1, p3-m4 (Figure 25.2); SC-3028, left P2-3; SC-3035, left $\mathrm{m} 1$; SC-3043, right p3$\mathrm{m} 2$; SC-3045, right p3-m 1; SC-3046, left m2; SC-3056, right $\mathrm{m} 2-4$; SC-3202, right $\mathrm{m} 1$; SC-3204, right $\mathrm{m} 2-3$; SC-3207, left $\mathrm{m} 2$; SC-3212, left $\mathrm{ml}$; SC-3238, right $\mathrm{m} 1$; SC-3245, left $\mathrm{m} 2$; SC-3250, left m1-2; SC-3260, left m3-4; SC-3382, left m2; SC3383, right $\mathrm{m} 2$; SC-3392c, left $\mathrm{m} 3$; SC-3397, left $\mathrm{m} 2$; SC-3399, left m2-3; SC-3412, right m2; SC-3419a, left M1.

Localities of new material. - The following specimens are from the Pincturas Formation in the upper valley of the Río Pinturas at: 1) Cueva de las Manos East, (Provincia de Santa Cruz) (MACN SC-3260); 2) Estancia El Carmen (upper) (MACN SC-3382). The following specimens are from rocks provisionally referred to the Pinturas Formation at Gobernador Gregores: MACN SC1242 (locality 3), SC-1616 (high locality), SC-1617 (low locality). The following specimen is from rocks provisionally referred to the Pinturas Formation at Lago Cardiel (Fault Hill locality, Provincia de Santa Cruz): MACN SC-1238. The following specimens are from the Santa Cruz Formation exposed along the Río Chalia, at: 1) estaca 2 (MACN SC-3399); 2) estaca 3 (MACN SC numbers 3392c, 3397); 3) estaca 5 (MACN SC numbers $3412,3419 a)$. The following specimens are from the Santa Cruz Formation at Monte León: 1) estaca 1 (MACN SC numbers 2881, 2886, 2895); 2) estaca 142 (MACN SC numbers 1203 , $1230,1462,1463,1471,1474,1475,1479)$. The following specimens are from the Santa Cruz Formation at Monte Observación (Estancia Cañadon de las Vacas, Provincia de Santa Cruz): 1) estaca 7 (MACN SC numbers 3015, 3025, 3028, 3035, 3043, 3045, 3046, 3056); 2) estaca 17 (MACN SC-2963); 3) estaca 19 (MACN SC numbers 1140, 1309, 1311, 3238, 3245, 3383); 4) estaca 20 (MACN SC-1319); 5) estaca 21 (MACN SC numbers $1249,1252,1254) ; 6$ ) estaca 29 (MACN SC-1356); 7) estaca 30 (MACN SC-1255); 8) estaca 31 (MACN SC-1265); 9) estaca 32 (MACN SC numbers 3202, 3204, 3207, 3212); 10) estaca 39 (MACN SC-1267; 11) estaca 47 (MACN SC-1369); 12) estaca 48 (MACN SC-1270); 13) estaca 51 (MACN SC-1374); 14) estaca 53 (MACN SC-1294); 15) estaca 54 (MACN SC-1290); 16) estaca 59 (MACN SC numbers 1305,1307$)$; 17) estaca 84 (MACN SC-1281); 18) estaca 108 (MACN SC-1151); 19) estaca 116 (MACN SC-2953); 20) estaca 125 (MACN SC-2989); 21) estaca 200 (MACN SC-3250); 22) estaca 203 (MACN SC-2977); 23) estaca 204 (MACN SC numbers 2888, 2900); 24) estaca 206 
TABLE 12-Specimen data for first three lower molars and first two upper molars of Palaeothentes lemoinei Ameghino from various localities in the Pinturas and Santa Cruz Formations, Provincia de Santa Cruz. In $=$ natural logarithm $(\mathrm{L} \times \mathrm{W})$ of molar; $\times=$ broken tooth. Measurements in millimeters.

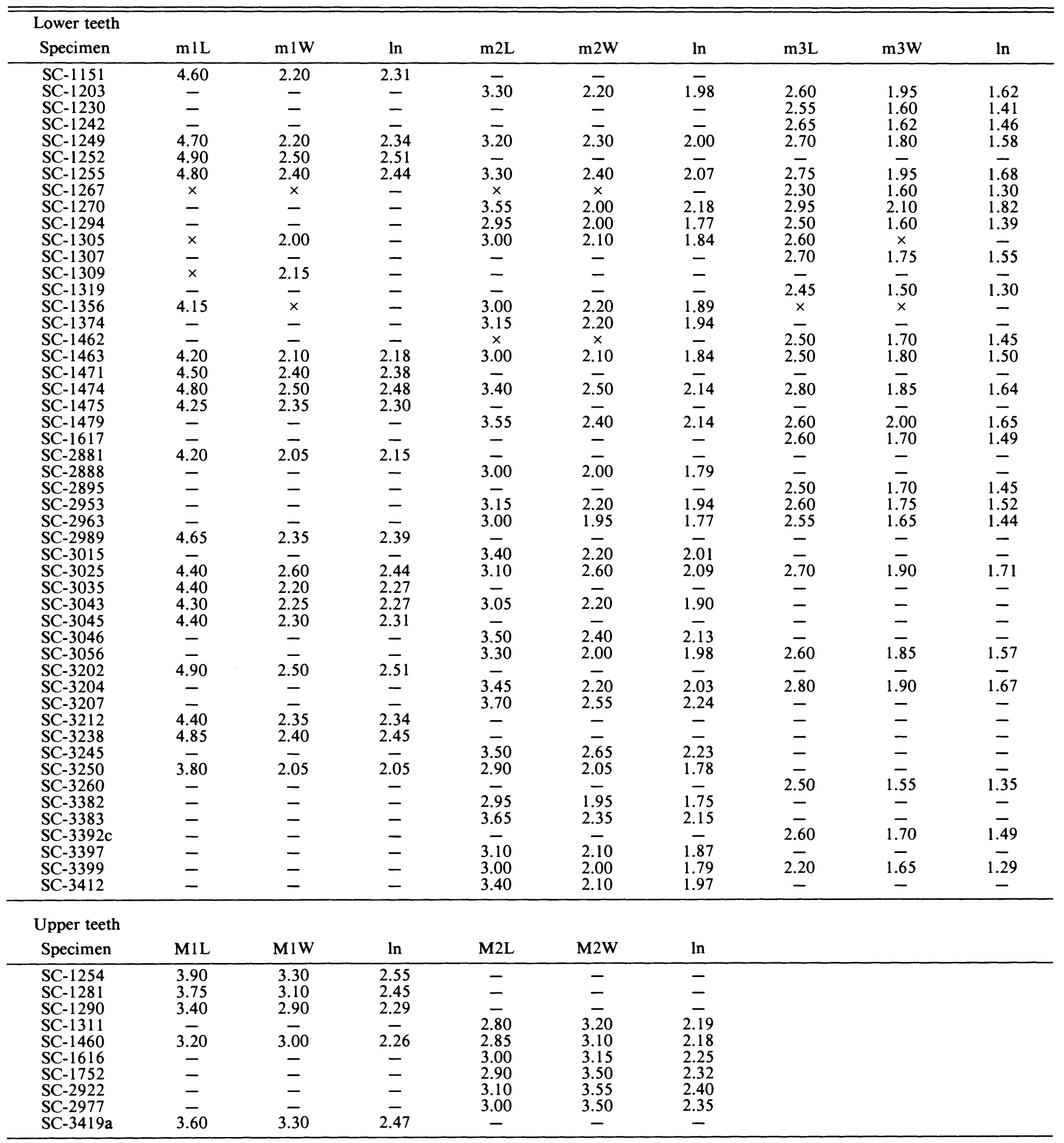

(MACN SC numbers 2912, 2922); 25) unknown locality (MACN SC-1752).

In addition to the above Argentine localities, specimens of Palaeothentes lemoinei are also known from Cerro Centinela, Corriguen-Aike, Karaiken, La Cueva, Quequa-Quemada, "Santa Cruz," Sehuen, and " 12 miles north of Cape Fairweather."
Distribution. - Santacrucian (early-middle Miocene) Pinturas and Santa Cruz Formations, Provincia de Santa Cruz, Argentina (Santacrucian temporal values $=59.2-98.9$ ); Alto Río Cisnes, Chile.

Discussion. - The 64 new specimens of Palaeothentes lemoinei more than treble the record of this scarce species of large 


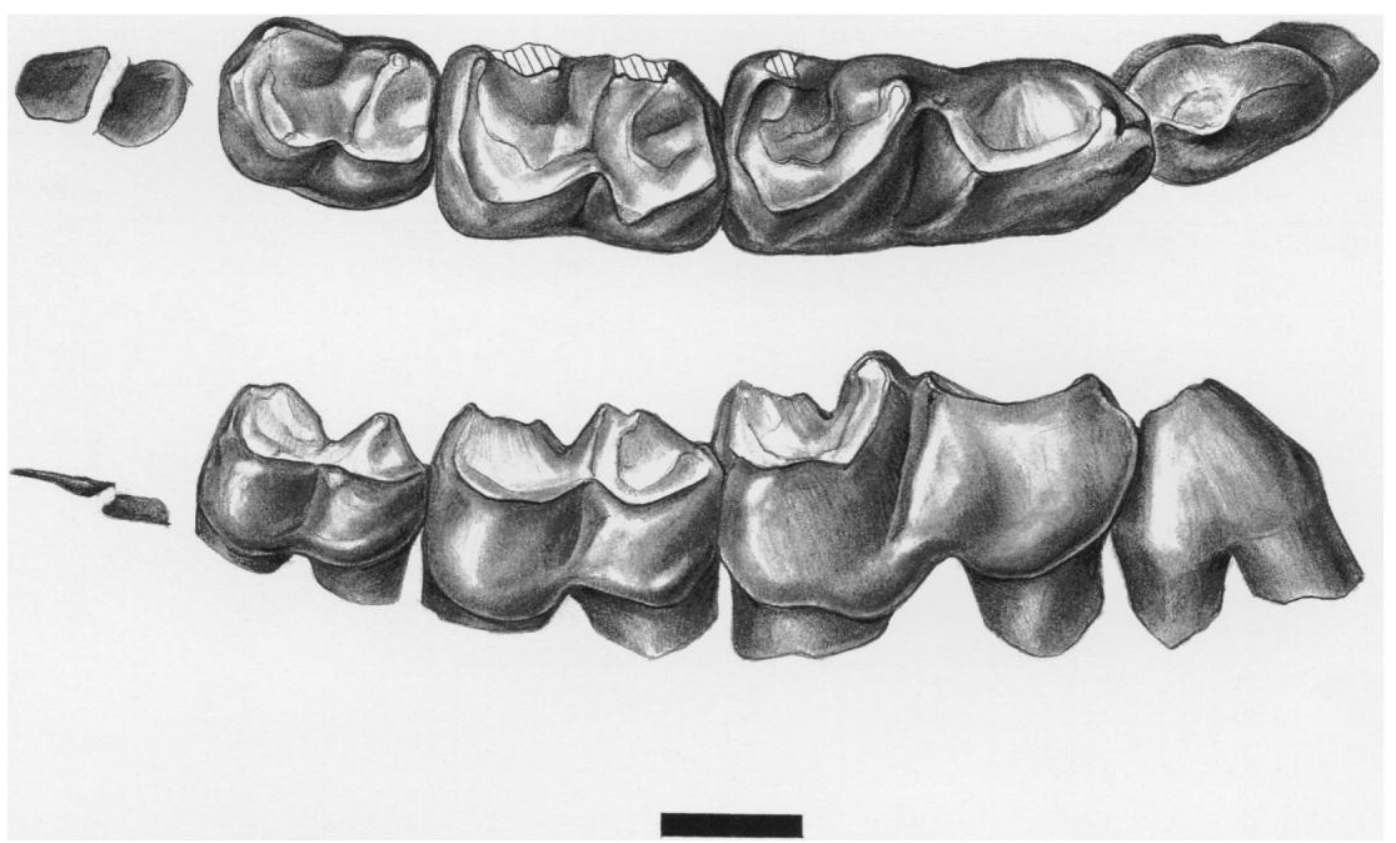

FiguRE 22-Palaeothentes aratae Ameghino (Palaeothentinae); MACN SC-1302, right p3-m3, in occlusal (top) and labial (bottom) aspects (bar $=2.0 \mathrm{~mm})$.

palaeothentine. In size, $P$. lemoinei is mostly likely to be confused with $P$. intermedius; however, it is quite distinct from that species and other Palaeothentes in its molar morphology, especially that of the upper molars. The distinctively triangular upper molars with the commonly lingually inflated, prow-like protocone is otherwise known only in some $P$. aratae. In the lower cheek teeth, $P$. lemoinei is generally separated easily from $P$. intermedius by the taller $\mathrm{p} 3$ in conjunction with overall larger size and commonly more trenchant entoconid.

In most features, $P$. lemoinei appears to be an advanced derived species with trenchant molars, a sharp constriction between the molar trigonids and talonids, and the unusual triangular form of the upper molars. It is more generalized than $P$. aratae in having an appreciably larger $\mathrm{m} 3$ area with respect to $\mathrm{m} 2$ area and in the less reduced M4. It is more generalized than $P$. intermedius and $P$. marshalli in having a taller $\mathrm{p} 3$, and more generalized than $P$. marshalli and $P$. migueli in having a shorter paraconid fissure.

Palaeothentes lemoinei was a large, borderline faunivorous/ herbivorous palaeothentid, with a body weight of approximately 200 grams (Strait et al., 1990, and unpublished data). See Figures 28-31 for molar area distributions of Palaeothentes lemoinei with respect to those of other Deseadan-Santacrucian Palaeothentidae.

\section{Palaeothentes aratae Ameghino, 1887} Figures 22, 25.3, 45

Palaeothentes aratae MORENO, 1882, p. 122 (nomen nudum). Palaeothentes aratae AMEGHINO, 1887, p. 5; SINCLAIR, 1906, p. 428; KRAGLIEVICH, 1953, p. 54; MARShall, 1980, p. 87.

Epanorthus aratae AMEGHINO, 1889, p. 272.

Holotype.-MACN 14, right mandibular ramus with p3-m4 (Marshall, 1980, fig. 29).

Revised diagnosis. - Largest species of Palaeothentes; m1-3 collectively 28-35 percent larger than in $P$. lemoinei. P1 (one example) putatively single-rooted in contrast to all other $\mathrm{Pa}$ laeothentes and Acdestis, and anterior cheek teeth more widely spaced. Differs from $P$. intermedius in having tall p3, developed about as in $P$. primus, $P$. minutus, and $P$. lemoinei. Lower molars broad and not trenchant, in contrast to $P$. pascuali, $P$. minutus, and $P$. lemoinei. Paraconid bifurcation on $\mathrm{ml}$ very shallow and short, in contrast to all other Palaeothentes excepting $P$. boliviensis, $P$. primus, and $P$. intermedius. Palaeothentes aratae shares the following with $P$. primus: p3 tall with weak or lacking anterobasal cusp; $\mathrm{m} 1$ paraconid bifurcation short and shallow; some $\mathrm{ml}$ with type 4 trigonid structure; $\mathrm{ml}$ with anterolabiallyposterolingually oblique protocristid; at least some $\mathrm{ml}$ with cristid obliqua meeting postcristid labial to metaconid; $\mathrm{m} 2$ with anteriorly expanded entoconid; and $\mathrm{m} 3$ very small with respect to $\mathrm{m} 2$. $P$. aratae differs from $P$. primus in its vastly larger tooth size. First lower molar with types 1, 2, 3, and 4 trigonid structure $(50 \%, 21 \%, 14 \%$, and $14 \%$, respectively-only known palaeothentid with all four trigonid varieties); $\mathrm{m} 2$ with less explicit vespiform constriction between trigonid and talonid than in $P$. lemoinei, and mean of $\mathrm{m} 3 / \mathrm{m} 2$ areas smaller than in all other Palaeothentes. Upper molars lacking acutely triangular form and sharply lingual protocone region of $P$. lemoinei, and M4 more reduced than in other species. See Table 13 for measurements.

Hypodigm. - The type specimen; the specimens listed by Marshall $(1980$, p. 87,88$)$; and the new material listed below.

New material. - MACN numbers SC-1 145A, right m2-4; SC1145B, left m2-4; SC-1261, right p3; SC-1295, right M3; SC1296, left m1; SC-1301, left p3-m1, m2 (part); SC-1302, right p3-m3 (Figure 22); SC-1306, right m2-3; SC-1320, left m2; SC1323, left $\mathrm{m} 1$, right $\mathrm{m} 2-3$; SC-1326, right p3-m3; SC-1331, left $\mathrm{m} 1$; SC-1359, right M1-4 (Figure 25.3); SC-1367, right p3-m2; SC-1372, left $\mathrm{m} 1$; SC-1379, left $\mathrm{m} 2$; SC-1383, right M2; SC1384, right $\mathrm{m} 2$; SC-1613, right $\mathrm{m} 1$; SC-2887, left $\mathrm{p} 2-3$; SC2924, right $\mathrm{ml} 1-3$; SC-2954, right $\mathrm{ml} 1-2$; SC-2955, left $\mathrm{ml}$; SC-2956, left m1; SC-2962, left m3; SC-2964, left p3; SC-2966, left p3-m 1; SC-2988, left M1-2; SC-3023, right P3; SC-3156, left $\mathrm{m} 2$; SC-3254, right $\mathrm{m} 1$ (Figure 45); SC-3385, right $\mathrm{p} 3-\mathrm{m} 1$.

Localities of new material. - The following specimens are from the Pinturas Formation at Estancia La Cañada: MACN SC numbers 1613,3156 . The following specimen is from the south bank of the Río Chalia at Estancia Mank Aike: MACN SC-3023. The 
TABLE 13-Specimen data for first three lower molars and first two upper molars of Palaeothentes aratae Ameghino from various localities in the Pinturas and Santa Cruz Formations, Provinicia de Santa Cruz. $\ln =$ natural logarithm $(\mathrm{L} \times \mathrm{W})$ of molar; $\times=$ broken tooth. Measurements in millimeters.

\begin{tabular}{|c|c|c|c|c|c|c|c|c|c|}
\hline \multicolumn{10}{|l|}{ Lower teeth } \\
\hline Specimen & $\mathrm{m} 1 \mathrm{~L}$ & $\mathrm{~m} 1 \mathrm{~W}$ & $\ln$ & $\mathrm{m} 2 \mathrm{~L}$ & $\mathrm{~m} 2 \mathrm{~W}$ & $\ln$ & $\mathrm{m} 3 \mathrm{~L}$ & $\mathrm{~m} 3 \mathrm{~W}$ & $\ln$ \\
\hline SC-1145A & - & - & - & 4.20 & 3.00 & 2.53 & 3.00 & 2.30 & 1.93 \\
\hline SC-1145B & - & - & - & 4.20 & 2.90 & 2.50 & 3.20 & 2.20 & 1.95 \\
\hline SC-1301 & 5.50 & 3.00 & 2.80 & - & - & - & - & - & - \\
\hline SC- 1302 & 6.00 & 2.80 & 2.82 & 4.00 & 2.80 & 2.42 & 3.00 & 2.20 & 1.89 \\
\hline SC-1306 & - & - & - & 4.00 & 2.90 & 2.45 & 2.90 & 2.30 & 1.90 \\
\hline SC-1320 & - & - & - & 4.00 & 2.80 & 2.42 & - & - & - \\
\hline SC- 1367 & 5.20 & 2.70 & 2.96 & 3.80 & 2.75 & 2.35 & - & - & - \\
\hline SC-1372 & 6.10 & 3.05 & 2.92 & - & - & - & - & - & - \\
\hline SC- 1379 & - & - & - & 3.60 & 2.50 & 2.20 & - & - & - \\
\hline SC-1384 & - & - & - & 4.45 & 3.15 & 2.64 & - & - & - \\
\hline SC-2924 & - & - & - & 3.65 & 2.70 & 2.29 & 2.85 & 2.10 & 1.79 \\
\hline SC-2954 & $\times$ & 2.70 & - & 4.00 & 2.85 & 2.43 & - & - & - \\
\hline SC-2955 & 5.35 & 2.75 & 2.69 & - & - & - & - & - & - \\
\hline SC-3385 & 5.10 & 2.85 & 2.68 & - & - & - & - & - & - \\
\hline \multicolumn{10}{|l|}{ Upper teeth } \\
\hline Specimen & M1L & M1W & $\ln$ & M2L & M2W & $\ln$ & & & \\
\hline SC-1359 & 4.40 & $x$ & - & 3.60 & 4.30 & 2.74 & & & \\
\hline SC- 1383 & 4.00 & 3.90 & 2.75 & - & - & - & & & \\
\hline SC-2988 & 4.50 & 4.50 & 3.01 & 3.50 & 4.50 & 2.76 & & & \\
\hline
\end{tabular}

following specimens are from the Santa Cruz Formation at Monte León, at: 1) estaca 1 (MACN SC-2887); 2) estaca 3 (MACN SC-2988). The following specimens are from the Santa Cruz Formation at Monte Observación (Estancia Cañadon de las Vacas, Provincia de Santa Cruz), at: 1) estaca 17 (MACN SC numbers 2955, 2956, 2962, 2964); 2) estaca 19 (MACN SC-3385); 3) estaca 20 (MACN SC-1320); 4) estaca 29 (MACN SC numbers 1359, 3254); 5) estaca 37 (MACN SC-1261); 6) estaca 51 (MACN SC-1372); 7) estaca 53 (MACN SC-1295); 8) estaca 59 (MACN SC numbers 1296, 1302, 1306); 9) estaca 68 (MACN SC-1301); 10) estaca 69 (MACN SC numbers 1323, 1326, 1331); 11) estaca 97 (MACN SC-1367); 12) estaca 114 (MACN SC1384); 13) estaca 116 (MACN SC numbers 1383, 2954); 14) estaca 120 (MACN SC-1379); 15) estaca 145 (MACN SC numbers 1145A, 1145B); 16) estaca 203 (MACN SC-2966); 17) estaca 206 (MACN SC-2924).

In addition to the above localities, specimens of Palaeothentes aratae are also known from Río Gallegos, "Santa Cruz," and Sehuen.

Distribution. - Santacrucian (early-middle Miocene) Pinturas and Santa Cruz Formations, Provincia de Santa Cruz, Argentina (Santacrucian temporal values $=66.4-89.3$ ).

Discussion. - The 32 new specimens here ascribed to Palaeothentes aratae more than quadruple the known hypodigm of this rare species and provide more knowledge of its geographic and stratigraphic distribution and its probable affinities. Because of the very large $\mathrm{m} 1-2$ size and unusually small $\mathrm{m} 3$, Palaeothentes aratae is one of the most distinctive species of the genus and is not easily confused with any other species of Santacrucian palaeothentine. It is by far closest in morphology to Colhuéhuapian $P$. primus, from which it differs only in its very large size and in possession of a very faint anterobasal cusp on p3 (see diagnosis). It differs considerably in both upper and lower molar morphology from its closest Santacrucian counterpart in size, $P$. lemoinei, which also has markedly smaller teeth and a considerably larger value for $\mathrm{m} 3 \mathrm{area} / \mathrm{m} 2$ area.

Palaeothentes aratae and the older but closely related $P$. primus differ from all other species of Palaeothentes in a combination of largely generalized characters: 1) tall, unreduced p3 (in contrast to $P$. intermedius); 2) possession of four types of $\mathrm{m} 1$ trigonid structure $(P$. aratae; $P$. primus and Carlothentes chubutensis possess only type 4$) ; 3$ ) broad lower molars that do not have trenchant cusps (in contrast to $P$. pascuali and $P$. minutus); 4) lower molars that are not so conspicuously constricted between the trigonid and talonid (in contrast to most other Palaeothentes species); 5) very short and shallow valley separating twinned moieties of $\mathrm{m} 1$ paraconid (contrasting especially with long, deep valleys in Palaeothentes marshalli, $P$. migueli, and Pilchenia lucina); 6) lack of accessory cuspules and styles (as occur in Trelewthentes rothi and Palaeothentes minu$t u s)$; 7) lack of acutely triangular upper molars with sharp, lingually distended protocone region (as in P. lemoinei); and 8) in having unreduced upper molar talons (as occur in $P$. marshallinot known for $P$. primus). Palaeothentes aratae is derived in its greatly reduced $\mathrm{m} 3$, the possible loss of a $\mathrm{P} 1$ root (claimed by Marshall, 1980, but see his fig. 30 in which the P1 alveolus in AMNH 9549 appears to have housed a two-rooted tooth or a tooth with perhaps coalesced roots), and the considerable reduction of M4. It also is derived with respect to most other Palaeothentes in the presence of an anterior mure on the $\mathrm{ml-}$ 2 entoconids and, with respect to other Palaeothentes species excepting $P$. primus, in having a very anterolabially-posterolingually oblique $\mathrm{m} 1$ protocristid.

MACN SC-3254, a relatively unworn right $\mathrm{ml}$ (Figure 45), is unique among specimens of Palaeothentes aratae in having very bunodont cusps lacking crests, very faint $\mathrm{ml}$ paraconid 
bifurcation (weaker than in $P$. primus or any other $P$. aratae), and a cristid obliqua that joins the protocristid well labial to the metaconid. The latter feature is otherwise only seen in Colhuéhuapian $P$. primus and underscores the ties of these two species. The other characters are primitive and comprise a unique combination, suggesting (as does the unique presence of all types $1-4$ of $\mathrm{ml}$ trigonid construction -type 4 occurs in MACN 14 and MACN SC-1302) that the genotype of $P$. aratae retained several exceedingly generalized palaeothentid (even pre-palaeothentid) dental features, some of which were expressed phenotypically from time to time.

Palaeothentes aratae was a very large frugivorous palaeothentid, with a body weight of approximately 550 grams (Strait et al., 1990, and unpublished data). See Figures 28-31 for molar area distributions of Palaeothentes aratae with respect to those of other Deseadan-Santacrucian Palaeothentidae.

\section{Genus Propalaeothentes n. gen.}

Epanorthus AMEGHINO, 1891, p. 305, 1894, p. 348

Palaeothentes SinClaIR, 1906, p. 431; MARSHALL, 1980, p. 72 (partim).

Type species. - Propalaeothentes lepidus (Ameghino, 1891).

Included species. - The type species and P. hatcheri n. sp. (infra).

Etymology. - Latin pro- (pref.); before, in front of; in allusion to several generalized characters the new genus possesses with respect to Palaeothentes.

Diagnosis.-Small to middle-sized palaeothentine. Propalaeothentes differs from Palaeothentes in: 1) having less elevated p3 (well below level of paraconid of $\mathrm{m} 1$ ); 2) having p3 commonly lacking anterobasal cusp; 3 ) lack of bifurcation of $\mathrm{m} 1$ paraconid; 4) having a generally much larger $\mathrm{m} 3 / \mathrm{m} 2$ area ratio $(\bar{x}=0.73)$; and 5) having shorter, less trenchant $\mathrm{m} 1$ and $\mathrm{m} 2$ entoconids. Differs from Pilchenia in lacking a twinned $\mathrm{m} 1$ metaconid, in having a transversely broader $\mathrm{m} 1$ protocristid, in lacking a paraconid on $\mathrm{m} 2$, in lacking a twinned $\mathrm{m} 2$ entoconid, in lacking crenulated enamel on $\mathrm{m} 1-3$, and in characters 2,3 , and 5 above (which also separate it from Palaeothentes). From Carlothentes, Propalaeothentes differs in its vastly smaller size, in lacking a twinned $\mathrm{m} 1$ paraconid, in having a short and narrow $\mathrm{p} 3 \mathrm{gen}-$ erally lacking an anterobasal cusp, in lacking the $m 2$ paraconid, in having a more anterior $\mathrm{m} 1$ metaconid, and in lacking a bent m 1 cristid obliqua.

Propalaeothentes lePidus (Ameghino, 1891)

Figures 23, 25.4, 25.5

Epanorthus lepidus AMEGHINo, 1891, p. 305

Palaeothentes lepidus SinCLAIR, 1906, p. 431.

Palaeothentes intermedius MARShall, 1980, p. 72 (partim).

Holotype.-MACN 5678, left p3-m4.

Diagnosis. - Differs from Propalaeothentes hatcheri $\mathbf{n}$. sp. in having: 1) much larger molars; 2) a deeper mandibular ramus; and 3 ) a considerably longer $\mathrm{m} l$ paracristid. Measurements in Table 7 .

Hypodigm. - The type specimen and MACN numbers SC989, left m1; SC-1237, right p3-m2 (Figure 23); SC-2903, left m1-2; SC-3160, left p3-m2 (Figure 25.4); SC-3161, right m13 (Figure 25.5); SC-3214, left p3-m1; SC-3394, right p3-m1; and SC-3396, left $\mathrm{m} 1$.

Localities of new material. -SC-989 is from the Pinturas Formation at Portezuelo Sumich Sur; SC-3214 is from the Pinturas Formation at Estancia El Carmen; SC-1237 is from rocks provisionally referred to the Pinturas Formation at Lago Cardiel (Fault Hill); MACN SC-3160 and SC-3161 are from the Pinturas Formation at Estancia La Cañada, at a level believed to be approximately equivalent to Loma de la Lluvia (upper part of

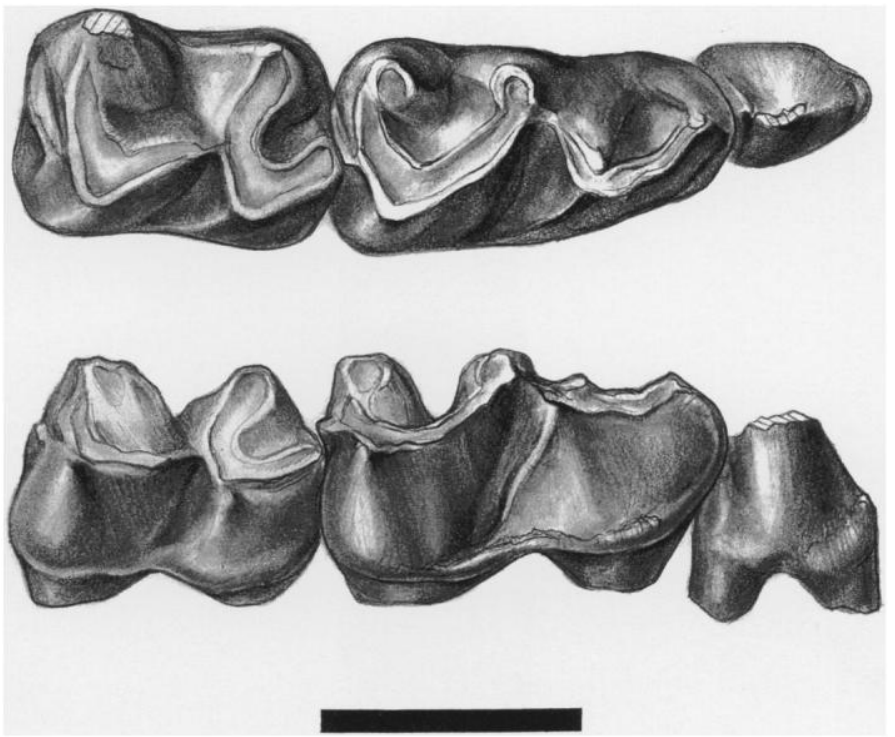

FIGURE 23-Propalaeothentes lepidus (Ameghino), n. gen. (Palaeothentinae); MACN SC-1237 (type), right p3-m2, in occlusal (top) and labial (bottom) aspects (bar $=2.0 \mathrm{~mm}$ ).

middle sequence of Pinturas Formation; see Bown and Larriestra, 1990) in the valley of the Rio Pinturas; SC-2903 is from the Santa Cruz Formation at Monte Observación, estaca 25; and SC-3394 and SC-3396 are from exposures of the upper part of the Santa Cruz Formation along the Rio Chalia, at estaca 3. The type specimen of Propalaeothentes lepidus is from an unknown locality at Monte Observación.

Distribution. - Santacrucian (early-middle Miocene) Pinturas and Santa Cruz Formations, Provincia de Santa Cruz, Argentina (Santacrucian temporal values $=59.2-80.08$ ).

Discussion. - Nine specimens of an unusual, small to middlesized palaeothentine intermediate in size between Palaeothentes minutus and $P$. intermedius occur in the Pinturas and Santa Cruz Formations. All specimens are reasonably complete for materials of palaeothentids, all are undamaged, and all have the same unusual morphology - provisions that strengthen our view that together they represent a distinct new form.

The new material of Propalaeothentes lepidus shows the p3 to be markedly less elevated than in Palaeothentes, Carlothentes, and Pilchenia and, except in SC-1237, p3 lacks the anterobasal cusp. The first lower molar lacks bifurcation of the paraconid in all nine specimens. Instead of a twinned cusp, there exists only a minor ridge beginning on the labial side of the paraconid and extending anteriorly and downward to near the base of the crown. A relatively tall p3 with an anterobasal cusp, associated with $\mathrm{ml}$ with a bifurcated paraconid, are among the most significant hallmarks of the genera Palaeothentes, Carlothentes, and Pilchenia, the first of which the new form otherwise closely resembles. The absence or different expression of various of these features are therefore important because they not only question placement of these nine specimens in either Palaeothentes minutus or $P$. intermedius (their closest size analogues), but even in the Palaeothentinae.

Sinclair (1906) noted that Ameghino's (1891) type of Epanorthus lepidus (MACN 5937, from Monte Observación) and Sinclair's referred sample of Palaeothentes lepidus (Ameghino; AMNH specimens 9596-9598 and 9600-all from Rio Gallegos and referred to $P$. intermedius by Marshall, 1980) are typified by tooth dimensions intermediate between those of Palaeothen- 

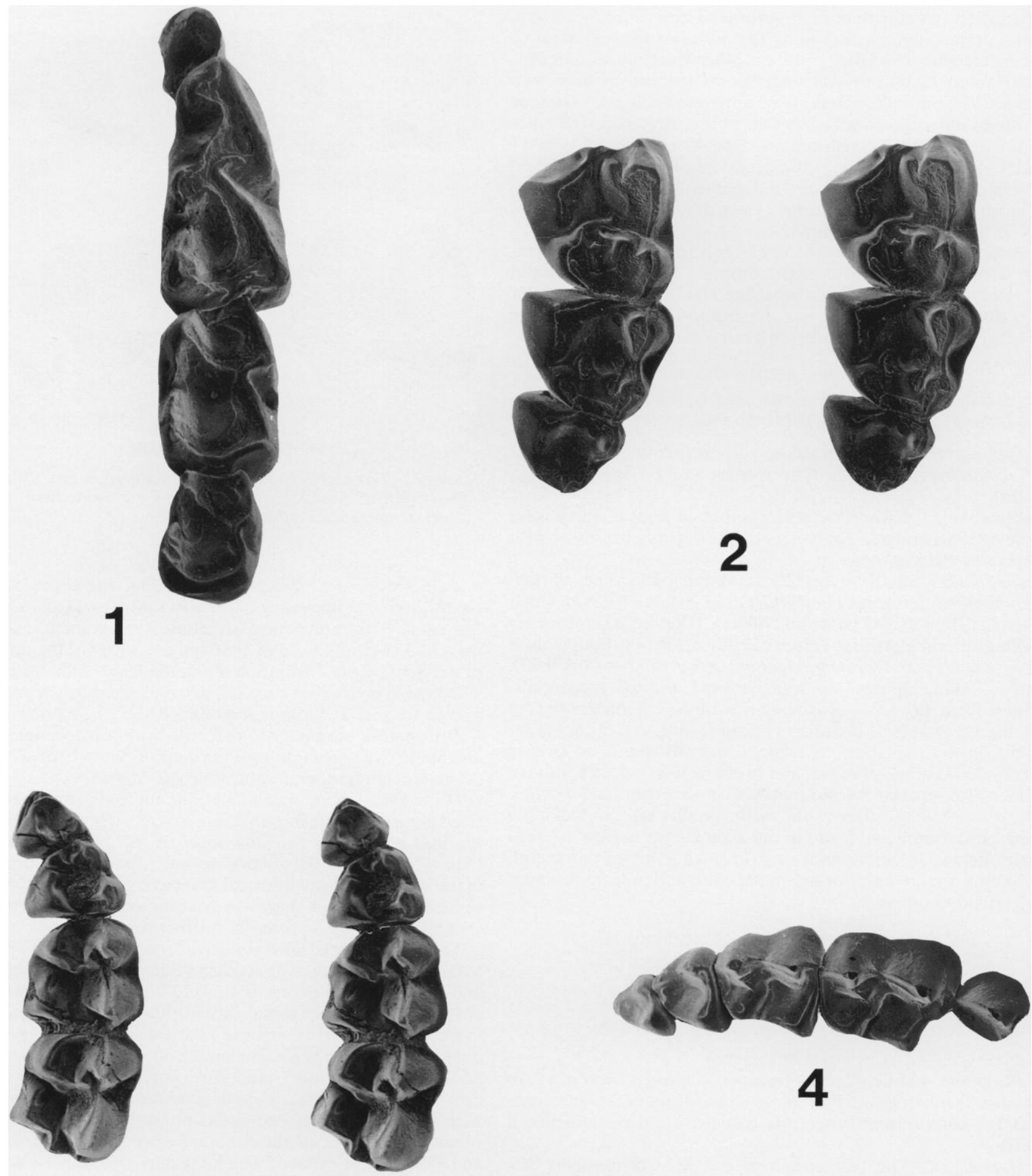

Figure 24-Dentitions of palaeothentine palaeothentids. 1, Palaeothentes primus Ameghino, occlusal aspect of MACN 377a, right p3-m3. 2, Palaeothentes marshalli n. sp., occlusal aspect of MACN CH-1440, left M1-3. 3, Palaeothentes minutus Ameghino, occlusal aspect of MACN SC-3286, right M1-4. 4, Palaeothentes intermedius Ameghino, occlusal aspect of MACN SC-2995, right P3-M4. All specimens $\times 10$. Stereopairs: $2,3$.

tes minutus and $P$. intermedius. The same is the case in specimens referred here to Propalaeothentes lepidus in which, for example, specimen SC-3161 is within the upper part of the size range of $P$. minutus, whereas SC-3160 has $\mathrm{m} 1$ somewhat too large for inclusion in $P$. minutus, and $\mathrm{m} 2$ within the range of $P$. intermedius. MACN SC-1237 is about the same size as $P$. intermedius.

Examination of Sinclair's referred materials of "Epanorthus" 
(="Palaeothentes") lepidus shows that although those specimens lack a deeply twinned $\mathrm{m} 1$ paraconid, they do possess a tiny anterobasal cusp on a very tall p3. MACN SC-1237, from Pinturas-like rocks at Lago Cardiel, as well as SC-3394 and SC3396 from the Río Chalia also have an anterobasal p3 cusp but, unlike Sinclair's referred sample, otherwise mirror the type of "Epanorthus" lepidus. Examination of AMNH 9597, 9598, and 9600 (AMNH 9596 was unavailable for study) shows that, where determinable, $\mathrm{p} 3$ size, $\mathrm{m} 1$ paraconid twinning, and molar size are all well within variability seen in the now much larger sample of Palaeothentes intermedius. Finally, $\mathrm{m} 1$ and $\mathrm{m} 2$ in both species of Propalaeothentes typically have shorter, less trenchant entoconids than in Palaeothentes, Carlothentes, and Pilchenia. Propalaeothentes therefore represents a distinct new genus of palaeothentine for which the only prior applicable name Epanorthus (coined by Ameghino in 1889 as a replacement name for Palaeothentes) is unavailable.

Propalaeothentes is generalized with respect to characters shared by Palaeothentes, Carlothentes, and Pilchenia (Palaeothentinae) in 1) lacking a twinned $\mathrm{m} 1$ paraconid and 2) in having more cuspidate (less trenchant) $\mathrm{m} \mathrm{1-2} \mathrm{entoconids.} \mathrm{It} \mathrm{is} \mathrm{relatively}$ more advanced than in Palaeothentes and Carlothentes in having a somewhat less elevated p3. Six specimens (67\%) of Propalaeothentes $\mathrm{m} 1$ have trigonid structure type 1 (MACN SC3160 and SC-3161 are good examples), whereas three (33\%) possess type 2 (MACN 5678, MACN SC-1237, and SC-3396). Types 1 and 2 are the two dominant trigonid structures in the Palaeothentinae, and the two closest size analogues of Propalaeothentes lepidus, Palaeothentes minutus and P. intermedius, are dominated by types 2 and 1, respectively.

Propalaeothentes differs from other palaeothentines in some ways that resemble Acdestis and the Acdestinae; however, the new genus differs from members of that subfamily and resembles palaeothentines in: 1) having a large, less reduced p3; 2) having an anterobasal p3 cusp in some specimens; 3) having a much shorter $\mathrm{m} 1$ paracristid; 4) having a vespiform constriction between the trigonid and talonid of $\mathrm{m} 2$; and 5) lacking extreme reduction of $\mathrm{m} 3$ size, relative to the size of $\mathrm{m} 2$.

Propalaeothentes lepidus was a small to medium-sized probably faunivorous palaeothentid. See Table 7 for measurements and Figures 28-31 for molar area distributions of Propalaeothentes lepidus with respect to those of other Deseadan-Santacrucian Palaeothentidae.

\section{Propalaeothentes hatcheri $n$. $s p$.} Figure 25.6

Holotype.-MACN SC-3408 (Figure 25.6), left mandibular ramus with m 1-3; only known specimen.

Diagnosis. - Differs from Propalaeothentes lepidus in having: 1) a 23-38 percent shallower mandible; 2) 20-60 percent smaller $\mathrm{ml}$ area; and 3) a much shorter $\mathrm{m} 1$ trigonid.

Age and locality. - Santacrucian; near base of Santa Cruz Formation along the Río Chalia (estaca 5); Estancia Viven Aike, Provincia de Santa Cruz.

Etymology. - For John Bell Hatcher, a pioneer paleontologist who explored exposures of the Santa Cruz Formation along the Rio Chalia in 1896.

Discussion. - The sole specimen of Propalaeothentes hatcheri adds to the diversity of dentally primitive members of the $\mathrm{Pa}$ laeothentinae (and indeed the family Palaeothentidae) and underscores the distinctiveness of genus Propalaeothentes. In addition to having a shallower mandible and much smaller cheek teeth, $P$. hatcheri is unique among palaeothentids in the exceptionally short $\mathrm{m} 1$ trigonid, manifested in a primitively very short paracristid. Among known palaeothentids, only Hondathentes cazador has such a generalized trigonid. The $\mathrm{m} 1$ of $P$. hatcher possesses a type 2 trigonid construction, common to a third of specimens of the larger $P$. lepidus. Propalaeothentes hatcheri also has a high value of $\mathrm{m} 3 \mathrm{area} / \mathrm{m} 2$ area of 0.75 ; exceeded among palaeothentines only by the means of Propalaeothentes lepidus, Pilchenia lucina, and Palaeothentes pascuali, and by a few specimens of Palaeothentes marshalli and P. minutus.

In Propalaeothentes lepidus there is considerable variability in molar size that has possibly resulted from our having but a few specimens from a lineage typified by a perhaps stratigraphically controlled distribution of variability. Some older specimens, for example MACN SC-3160 and SC-3161 from the Pinturas Formation at Estancia La Cañada, are smaller than other $P$. lepidus and appear to have a marginally shorter trigonid, whereas the much younger MACN SC-3394 and SC-3396 from near the top of the Santa Cruz Formation along the Río Chalia (estaca 3) have the largest teeth and longest trigonids of any Propalaeothentes. The type of Propalaeothentes hatcheri is older than any Santa Cruz Formation $P$. lepidus, but is probably younger than the specimens from the Pinturas Formation at Estancia La Cañada (and is certainly younger than a very large $P$. lepidus from Estancia El Carmen). Despite the great variability seen in $P$. lepidus, the new species $P$. hatcheri clearly lies morphologically and biometrically well outside the envelope of expected $P$. lepidus variability and must be regarded to have been a somewhat generalized survivor of an earlier part of the Propalaeothentes lineage.

Propalaeothentes hatcheri was a diminutive, possibly faunivorous palaeothentine with teeth about the size of those in Palaeothentes minutus. See Table 7 for measurements.

\section{Genus Pilchenia Ameghino, 1903}

Pilchenia Ameghino, 1903, p. 128; LoOMIs, 1914, p. 222; MARShall AND PASCUAL, 1977, p. 111

Palaeothentes PATterson AND MARShall, 1978, p. 82; MARShall, 1980, p. 77.

Type species. - Pilchenia lucina Ameghino, 1903, p. 128.

Revised diagnosis. - Very large palaeothentine. In addition to distinctive features observed by Patterson and Marshall (1978, p. 83), Pilchenia is clearly separable from Carlothentes chubutensis and species of Palaeothentes in the following suite of characters: 1) lower third premolar relatively lower with respect to anterior margin of $\mathrm{ml}$;2) $\mathrm{ml}$ cristid obliqua joining center of labial part of posterior moiety of metaconid; 3) $\mathrm{ml}$ with more pronounced and more posteriorly attenuated twinned paraconid, with paraconid groove extending halfway to protoconid; 4) $\mathrm{m} 1$ with transversely very narrow protocristid; 5) $\mathrm{m} 2$ with twinned entoconid; and 6) m1-3 with crenulated enamel. Pilchenia and Carlothentes chubutensis share $\mathrm{ml}$ with type 4 trigonid structure coupled with very short, transverse protocristidtype 4 structure with a very deep labial valley separating anterior and posterior moieties of twinned metaconid. Pilchenia differs from Propalaeothentes in having: a bifurcated $\mathrm{m} 1$ paraconid; trigonid type 4 ; a transversely much more narrow protocristid; crenulated molars with twinned $\mathrm{m} 2$ entoconid; and longer, more trenchant entoconids on $\mathrm{m} 1$ and $\mathrm{m} 2$.

Included species. - The type species only.

Distribution.-Deseadan rocks at Cabeza Blanca, southeastern Provincia del Chubut, Argentina.

Pilchenia lucina Ameghino, 1903

Pilchenia lucina AMeghino, 1903, p. 128; LOOMIS, 1914, p. 222; MARShall and Pascual, 1977, p. 113.

Palaeothentes lucina PATTERSON AND MARShall, 1978, p. 82; MARShALL, 1980, p. 77.

Holotype.-MACN 52-371, left m3.

Diagnosis. - Only known species; as for genus. See Table 7 for measurements. 

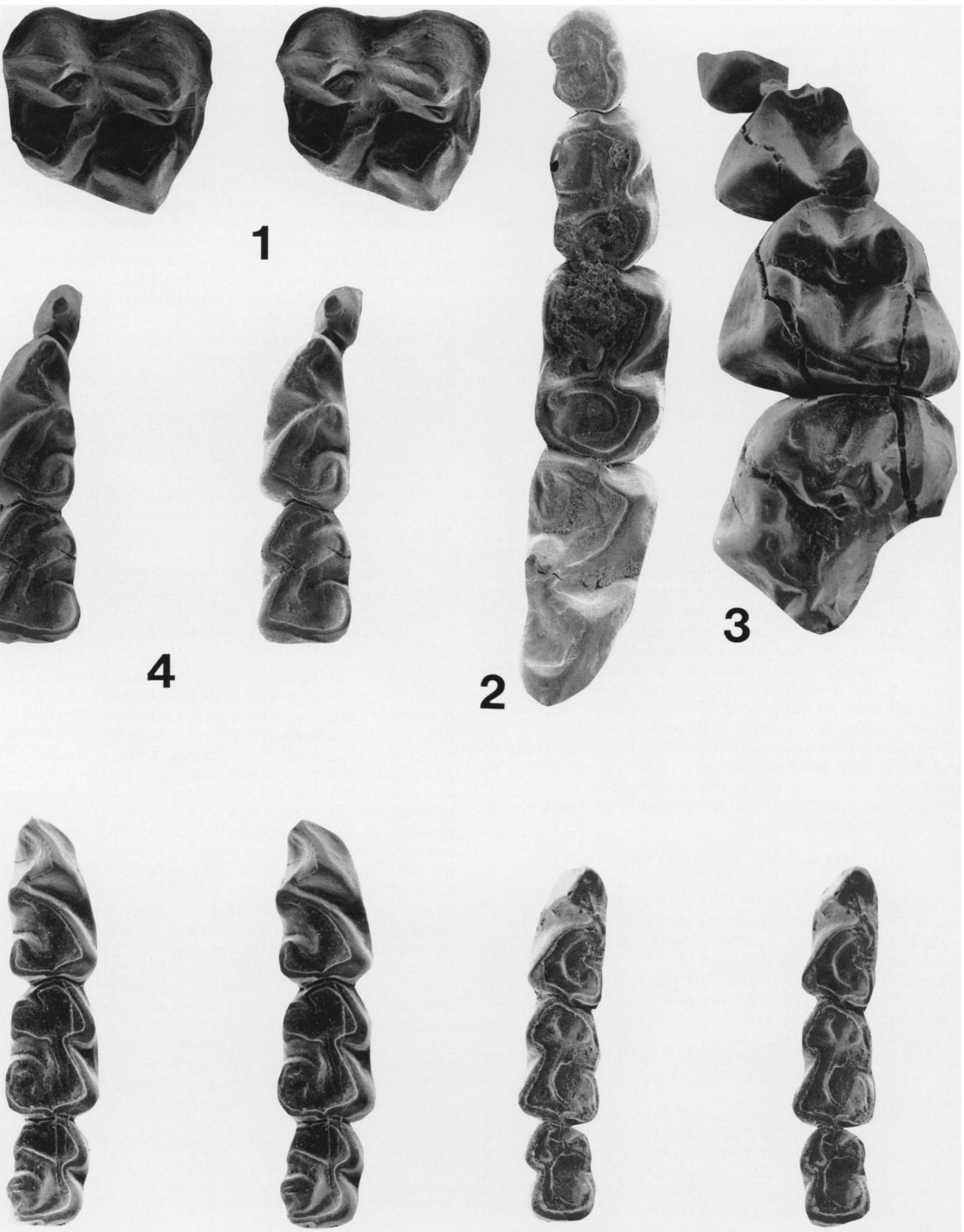

5

6 
Hypodigm. - The type specimen and AC 3110, left p3-m4 (Marshall, 1980, fig. 24).

Distribution. -ACM 3110 is from Deseadan (latest Oligocene or earliest Miocene) rocks near Cabeza Blanca, coastal Provincia del Chubut, Argentina. Marshall and Pascual (1977) believed the type specimen to have been collected on the Gran Barranca south of Lago Colhué-Huapi; however, Patterson and Marshall (1978) suggested that both specimens actually came from Cabeza Blanca.

Discussion. - Though Marshall and Pascual (1977, p. 113) maintained the validity of Ameghino's (1903) Pilchenia (“. . . el genero Pilchenia es ciertamente valido"), Patterson and Marshall (1978) transferred the genus to Palaeothentes, noting both an absence of diagnostic generic characters cited for Pilchenia by Ameghino and close similarity of the monotypic species, $P$. lucina, to species of Palaeothentes studied by them. Marshall's (1980) discussion of "Palaeothentes" lucina duplicated that of Patterson and Marshall (1978).

Considering the relatively minor but numerous and consistent morphologic criteria utilized by most workers to separate genera of palaeothentids, we believe that Pilchenia is a valid genus and one quite distinct from, though closely related to, Palaeothentes.

The $\mathrm{m} 1$ is more complicated in Pilchenia by virtue of the twinned metaconid and the posterior attenuation of the valley separating the twinned moieties of the paraconid. This feature is much more pronounced than even in Colhuéhuapian Palaeothentes marshalli or $P$. migueli, and its strong expression in Pilchenia is so distinctive that it led Loomis $(1914$, p. 222) to remark on the presence of an "incipient" cusp "on the inner face of the large anterior cusp." Additionally, $\mathrm{ml}$ in Pilchenia lucina has a protocristid that is exceedingly narrow transversely and the first three molars possess crenulated enamel. All of these features, in addition to the slightly less elevated $\mathrm{p} 3$, are derived relative to the condition in comparable teeth of all species of Palaeothentes. The sole specimen of $\mathrm{m} 2$ in $P$. lucina possesses a paraconid, a cusp lost in $\mathrm{m} 2$ of other palaeothentines (but present in Trelewthentes and some Acdestis), as well as a twinned entoconid. The ratio of the area of $\mathrm{m} 3$ to $\mathrm{m} 2$ (a generalized feature) is high in P. lucina, and is matched only in Palaeothentes pascuali, Trelewthentes rothi, and two specimens of Palaeothentes minutus.

Pilchenia lucina was a medium-large palaeothentid of uncertain dietary habits. See Figures 28-31 for molar area distributions of Pilchenia lucina with respect to those of other Deseadan-Santacrucian Palaeothentidae.

Family PALAEOTHENTIDAE, incertae sedis Genus HONDATHENTES

Dumont and Bown, in press

Hondathentes DumoNT AND Bown, in press.

Type species. - Hondathentes cazador Dumont and Bown, in press; only known species.

Distribution. - Honda Group, La Venta Formation (middleupper Miocene), Colombia.

Revised diagnosis. - Hondathentes differs from palaeothentines and resembles acdestines in having: 1) a paraconid on $\mathrm{m} 1$ that is not bifurcated (excepting Propalaeothentes); and 2) a p3
TABLE 14-Derived dental characters of the Palaeothentidae used to reconstruct phylogenies of Acdestinae (Figure 27) and Palaeothentinae (Figure 42). $[A]=$ absolute characters, $[\mathrm{T}]=$ transient characters, $[\mathrm{V}]=$ variable characters, $[\mathrm{C}]=$ convergent characters (discussed in text).

1. loss of one P1 root [A]

2. occasional reduction or loss of $\mathrm{p} 2[\mathrm{~A}]$

3. talonid of $\mathrm{p} 3$ narrow [T, C]

4. p3 slightly shorter than elevation of $\mathrm{ml}$ paraconid $[\mathrm{T}, \mathrm{C}]$

5. p3 very small and much shorter than elevation of $\mathrm{ml}$ paraconid [T]

6. p3 double-rooted, but with fusion of roots on labial side at alveolar border [T]

7. $\mathrm{p} 3$ single-rooted $[\mathrm{T}]$

8. p3 minute and canted anteriorly $[\mathrm{T}]$

9. loss of anterobasal cusp on $\mathrm{p} 3[\mathrm{~A}, \mathrm{C}]$

10. $\mathrm{ml}$ with type 1 trigonid $[\mathrm{T}, \mathrm{V}]$

11. $\mathrm{m} 1$ with type 2 trigonid $[\mathrm{T}, \mathrm{V}]$

12. $\mathrm{ml}$ with type 3 trigonid [T, V]

13. $\mathrm{ml}$ with type 4 trigonid [T, V]

14. $\mathrm{ml}$ paraconid shorter than protoconid on unworn teeth $[\mathrm{A}]$

15. $\mathrm{ml}$ paraconid shallowly bifurcated [T]

16. $\mathrm{ml}$ paraconid deeply bifurcated $[\mathrm{T}]$

17. $\mathrm{m} 1$ paraconid very deeply bifurcated $[\mathrm{T}]$

18. $\mathrm{ml}$ paracristid long $[\mathrm{T}, \mathrm{C}]$

19. $\mathrm{m} 1$ paracristid very long $[\mathrm{T}]$

20. $\mathrm{ml}$ paracristid very oblique $[\mathrm{T}]$

21. $\mathrm{ml}$ protocristid narrow transversely $[\mathrm{A}]$

22. $\mathrm{m} 1$ protocristid somewhat anterolabially-posterolingually oblique $[\mathrm{T}, \mathrm{C}]$

23. $\mathrm{ml}$ protocristid very anterolabially-posterolingually oblique [T, C]

24. $\mathrm{m} 1$ metaconid situated very posteriorly $[\mathrm{A}]$

25. $\mathrm{m} 1$ talonid very short $[\mathrm{A}]$

26. $\mathrm{ml}$ with cristid obliqua bent at midline [A]

27. $\mathrm{ml}$ with anterior mure on entoconid $[\mathrm{A}]$

28. $\mathrm{ml}$ with closed entoconid notch $[\mathrm{A}]$

29. $\mathrm{m} 1$ and $\mathrm{m} 2$ with trenchant entoconids $[\mathrm{T}, \mathrm{V}]$

30. $\mathrm{m} 2$ paraconid lost $[\mathrm{A}, \mathrm{C}]$

31. $\mathrm{m} 2$ with closed entoconid notch $[\mathrm{A}, \mathrm{C}]$

32. $\mathrm{m} 2$ entoconid twinned $[\mathrm{A}]$

33. $\mathrm{m} 2$ with anterolingually-posterolabially oriented protocristid [A]

34. $\mathrm{m} 2$ with greatly reduced to absent protocristid, and trigonid and talonid basins confluent [T, V]

35. $\mathrm{m} 2$ and $\mathrm{m} 3$ with distinct vespiform constriction at cristid obliqua and entoconid notch [T]

36. $\mathrm{m} 2$ and $\mathrm{m} 3$ very narrow $[\mathrm{T}]$

37. $\mathrm{m} 3 \mathrm{area} / \mathrm{m} 2$ area large, mean $=0.7$ or more $[\mathrm{T}, \mathrm{V}]$

38. $\mathrm{m} 3 \mathrm{area} / \mathrm{m} 2$ area moderate, mean $=0.6-0.7[\mathrm{~T}, \mathrm{~V}, \mathrm{C}]$

39. $\mathrm{m} 3 \mathrm{area} / \mathrm{m} 2$ area small, mean = less than $0.6[\mathrm{~T}, \mathrm{~V}, \mathrm{C}]$

40. M1 with hypocone platform lingually expanded [T]

41. M4/m4 greatly reduced, lacking distinct cusps [T, C]

42. incipiently trenchant molars $[\mathrm{T}, \mathrm{V}]$

43. moderately trenchant molars $[\mathrm{T}, \mathrm{V}]$

44. trenchant molars [T, V]

45. very trenchant molars $[\mathrm{T}, \mathrm{V}]$

46. overall tooth size decreases in size through time $[T, C]$

47. molars with crenulated enamel [A]

48. molars exodaenodont $[\mathrm{A}]$

49. molar cusps inwardly canted, appearing internally dispersed in occlusal view $[\mathrm{T}, \mathrm{V}]$

50. termination of $\mathrm{ml}$ protocristid confluent with cristid obliqua at metaconid or, if separate from metaconid, protocristid terminates anterior to it but at equivalent lingual position [A]

51 . $\mathrm{M} 1 / \mathrm{m} 1$ very large, $M 2-4 / \mathrm{m} 2-4$ appreciably smaller and molars decrease in size posteriorly [A]

52. marked shallowing of mandibular ramus $[\mathrm{T}, \mathrm{C}]$

FIGURE 25-Dentitions of palaeothentine palaeothentids. 1, Palaeothentes migueli n. sp., occlusal aspect of MACN CH-1462, right M1. 2, Palaeothentes lemoinei Ameghino, occlusal aspect of MACN SC-3025, left i2-p1 (not shown) and m1-4. 3, Palaeothentes aratae Ameghino, occlusal aspect of MACN SC-1359, right M1-4. 4, Propalaeothentes lepidus (Ameghino), $n$. gen., occlusal aspect of MACN SC-3160, left p3m2. 5, Propalaeothentes lepidus (Ameghino), n. gen., occlusal aspect of MACN SC-3161, right m1-3. 6, Propalaeothentes hatcheri n. sp., occlusal aspect of MACN SC-3408 (type), left m1-3. 1 is $\times 15,2$ through 6 are $\times 10$. Stereopairs: $1,4-6$. 


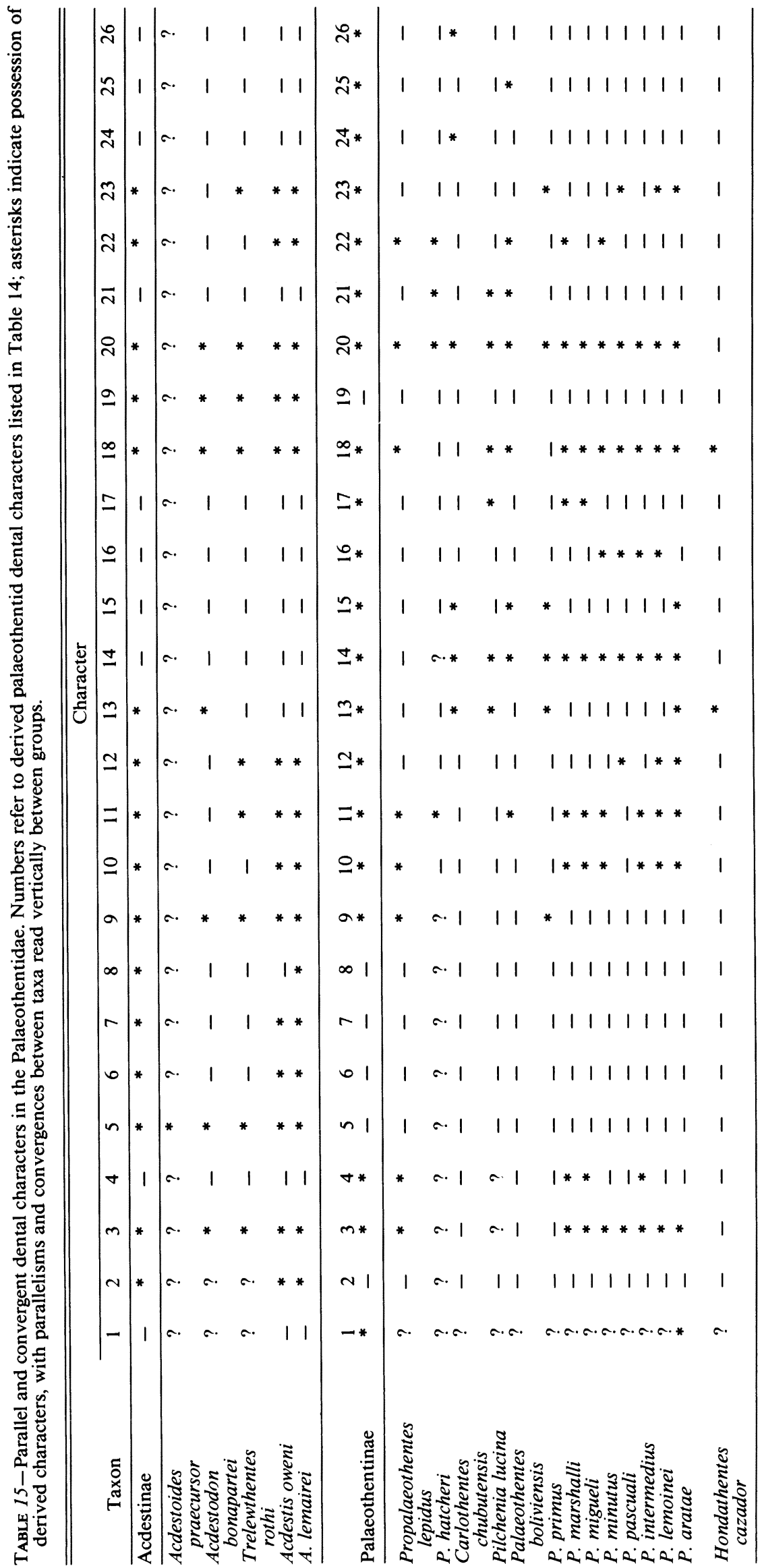




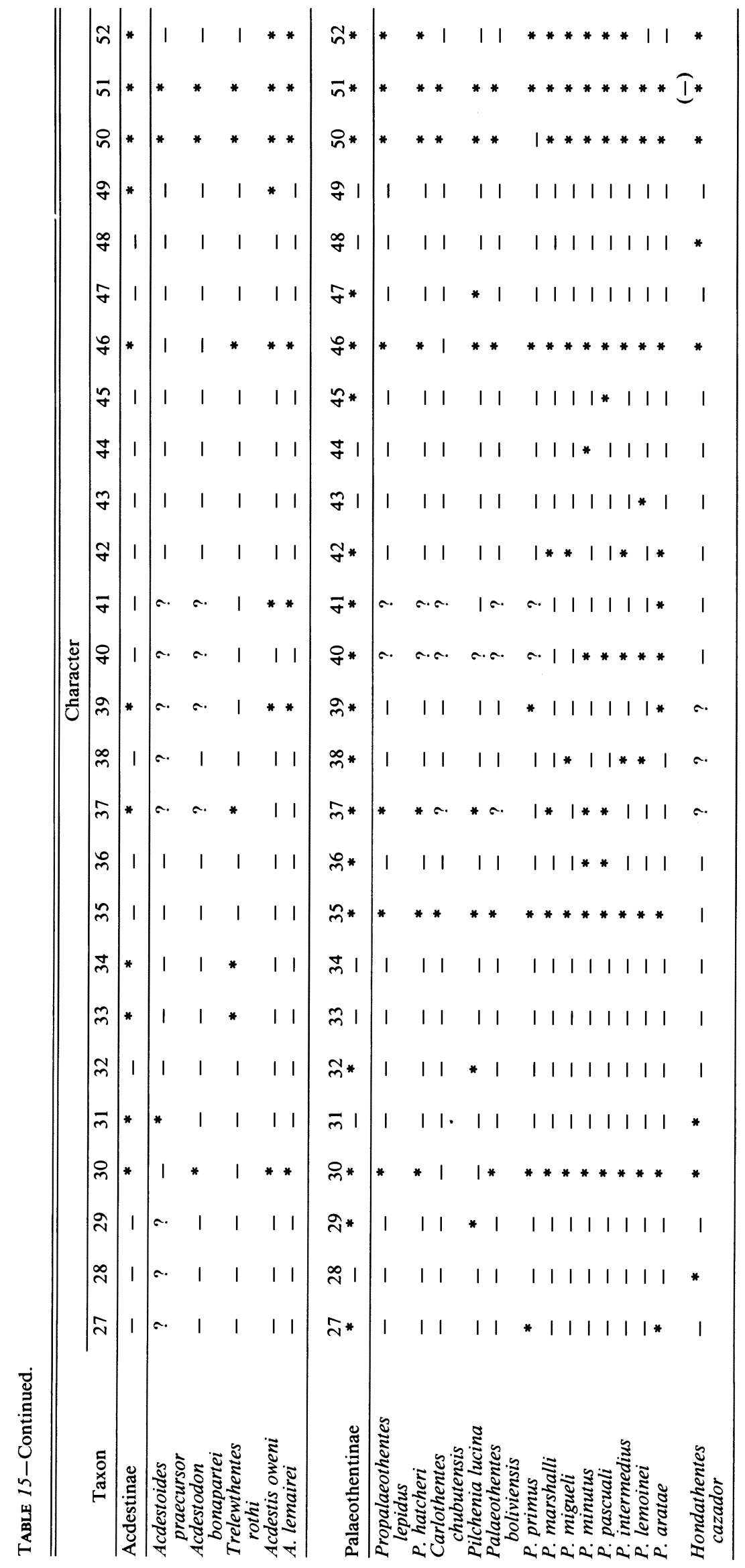


that lacks an anterobasal cusp. Hondathentes differs from acdestines and resembles palaeothentines in having: 1) a p3 crown that is as tall as the paraconid of $\mathrm{m} 1 ; 2$ ) a very short $\mathrm{m} 1$ paracristid (even shorter than in palaeothentids, excepting Propalaeothentes hatcheri); and 3) more peripherally (less internally) situated lingual cusps. Differs from both Palaeothentinae and Acdestinae in having: 1) a p3 that is broad and basined posteriorly; 2) a more transverse, anterolingually-posterolabially oriented $\mathrm{ml}$ paracristid; 3) $\mathrm{m} 1$ and $\mathrm{m} 2$ that lack an entoconid notch; and 4) an M1 postprotocrista that is confluent with the anterior margin of the hypocone platform. Differs from all other palaeothentids excepting Palaeothentes migueli, $P$. marshalli, and $P$. lemoinei in having a hypocone area on $\mathrm{M} 1$ that is unexpanded lingually. Differs from all palaeothentids in having exodaenodont molars, and from all palaeothentids excepting $A \mathrm{C}$ destodon, Pilchenia, Carlothentes, Palaeothentes primus, and some $P$. aratae in having type 4 trigonid structure.

HONDATHENTES CAZADOR

Dumont and Bown, in press

Holotype.-INGEOMINAS 250440, right ramus with p3-m2. Diagnosis. - Only known species; as for genus. Measurements in Table 7.

Hypodigm. - The type specimen and probably INGEOMINAS 250342, right M3; INGEOMINAS 251008, right M1.

Distribution. - As for genus.

Discussion.-Monotypic Hondathentes cazador is an enigmatical and important taxon. Not only do the three specimens of this species extend the youngest temporal record of the $\mathrm{Pa}$ laeothentidae to the post-Santacrucian, they also expand the geographic range of the family from a large region in Patagonia (with single outliers in Chile and Bolivia) to Colombia. By inference, the range of the family now effectively embraces much, if not most, of South America.

The dental morphology of $H$. cazador is equally significant; not only is that species the youngest and most geographically disparate palaeothentid, it also exhibits the most generalized known palaeothentid dentition. Excepting unique dental attributes of Hondathentes, examination of character polarities in all Caenolestoidea indicate that most of the diagnostic dental characters in Hondathentes are generalized for Palaeothentidae; the two possible exceptions being: 1) the lack of an anterobasal cusp on p3 (of doubtful polarity); and 2) the lack of an entoconid notch on $\mathrm{m} 1$ and $\mathrm{m} 2$ (possibly an early derived acdestine character restricted to the first two molars of Hondathentes and present in at least $\mathrm{m} 2$ of Acdestoides). If the lack of the anterior p3 cusp is generalized for the family, Hondathentes is an excellent primitive morphotype for Palaeothentidae. If, instead, lack of that cusp is derived, Hondathentes is a suitable antecedant for the Palaeothentinae. In either case, the known dentition of Hondathentes cazador appears to be near that of the stem palaeothentid.

One specimen each of M1 and M3 are known for $H$. cazador (Dumont and Bown, in press). Both are very generalized, tribospenic teeth with deep basins. Ml also has a linguolabially short talon and a small but distinct protoconule. The hypocone platform is primitively very narrow as it is in Palaeothentes marshalli and $P$. lemoinei, and contrasts with the condition seen in all other Palaeothentidae. A unique, apparently advanced character of $\mathrm{M} 1$ is the confluence of the postprotocrista with the anterior margin of the hypocone platform. In all other palaeothentids, a pronounced fissure separates this crista from the hypocone platform. M3 resembles unworn examples of that tooth in Acdestis in having a slight, labially directed fold at the anterior margin of the metacone (e.g., compare INGEOMINAS 250342 with FMNH P13160).
Hondathentes cazador was a small palaeothentid of uncertain dietary preferences. See Figures 28 and 29 for molar area distributions of Hondathentes cazador with respect to those of other Deseadan-Santacrucian Palaeothentidae.

\section{EVOLUTION OF PALAEOTHENTIDAE}

Until very recently, knowledge of the Palaeothentidae and their evolution was limited to about 170 specimens of teeth and jaws from approximately 20 scattered sites in the southern extremity of Argentina and one in Bolivia. For the most part, no detailed locality information exists for that material and the precise locations of several sites are either unknown or conjectural-none are associated with useful stratigraphic documentation. In the last 10 years, the amount of palaeothentid material has more than quadrupled, the geographic range of the family has been extended into both Chile and Colombia, the first large collections have been obtained from rocks of Colhuéhuapian age, and the considerably richer Santacrucian record has been substantially augmented by numerous stratigraphically documented specimens.

Ameghino described 16 genera and 37 species of palaeothentids - a figure reduced to but two genera and 10 species by Marshall (1980), and expanded to nine genera and 19 species in this work. Study of the new taxa described here and correlation of their dental morphologies with those of better known palaeothentids indicate that known fossil Palaeothentidae record but a fragment of what was once an exceedingly diverse group with a complex evolutionary history. Convergence, both within and between palaeothentid subfamilies was manifestly common, and representatives of the family were almost certainly widespread over most of South America at different times during the late early through later Tertiary.

To assist in the elucidation of palaeothentid evolution, lists of derived dental characters of the Palaeothentidae were compiled (Tables 14 and 15). Four categories of characters are recognized: absolute, transient, variable, and convergent (see also Bown and Rose, 1987, p. 23). Absolute characters are those with expressions of presence or absence only, with no known intermediate morphologies (e.g., presence or absence of the $\mathrm{m} 2$ paraconid). Transient characters are those having several expressions but which are typified by the replacement of an earlier expression by one or more succeeding, younger, and different expressions (e.g., bifurcation of the paraconid of $\mathrm{ml}$ in Palaeothentinae). Variable characters are those that express several different morphologies, none of which appear to have temporally controlled distributions, although some are to some extent temporally restricted (e.g., trigonid structure types $1-4$ in Palaeothentidae). Convergent characters are absolute, transient, or variable characters that were acquired independently (and at different times) in distinct palaeothentid lineages (e.g., loss of the $\mathrm{m} 2$ paraconid). Note that certain characters may belong to two, or even three, categories. For example, presence or absence of the $\mathrm{m} 2$ paraconid is absolute, whereas its distribution (in Acdestinae and Palaeothentinae but not in any common ancestor of both) is convergent. Similarly, the presence or absence or expression of the bifurcated $\mathrm{ml}$ paraconid is absolute in separating the clade Propalaeothentes + Acdestis + Hondathentes from the clade "rest of Palaeothentinae"; yet its expression is transient within the clade "rest of Palaeothentinae" in the differentiation of Pilchenia, on the one hand, from Palaeothentes and Carlothentes on the other.

Acdestinae.-Caenolestoid marsupials (Caenolestoidea, incertae sedis) are first known from a single damaged tooth of Casamayoran (early Eocene) age (Simpson, 1948; Marshall, 1980). The earliest remains of unquestioned palaeothentids occur in later Oligocene (Deseadan) rocks of the Salla-Luribay 


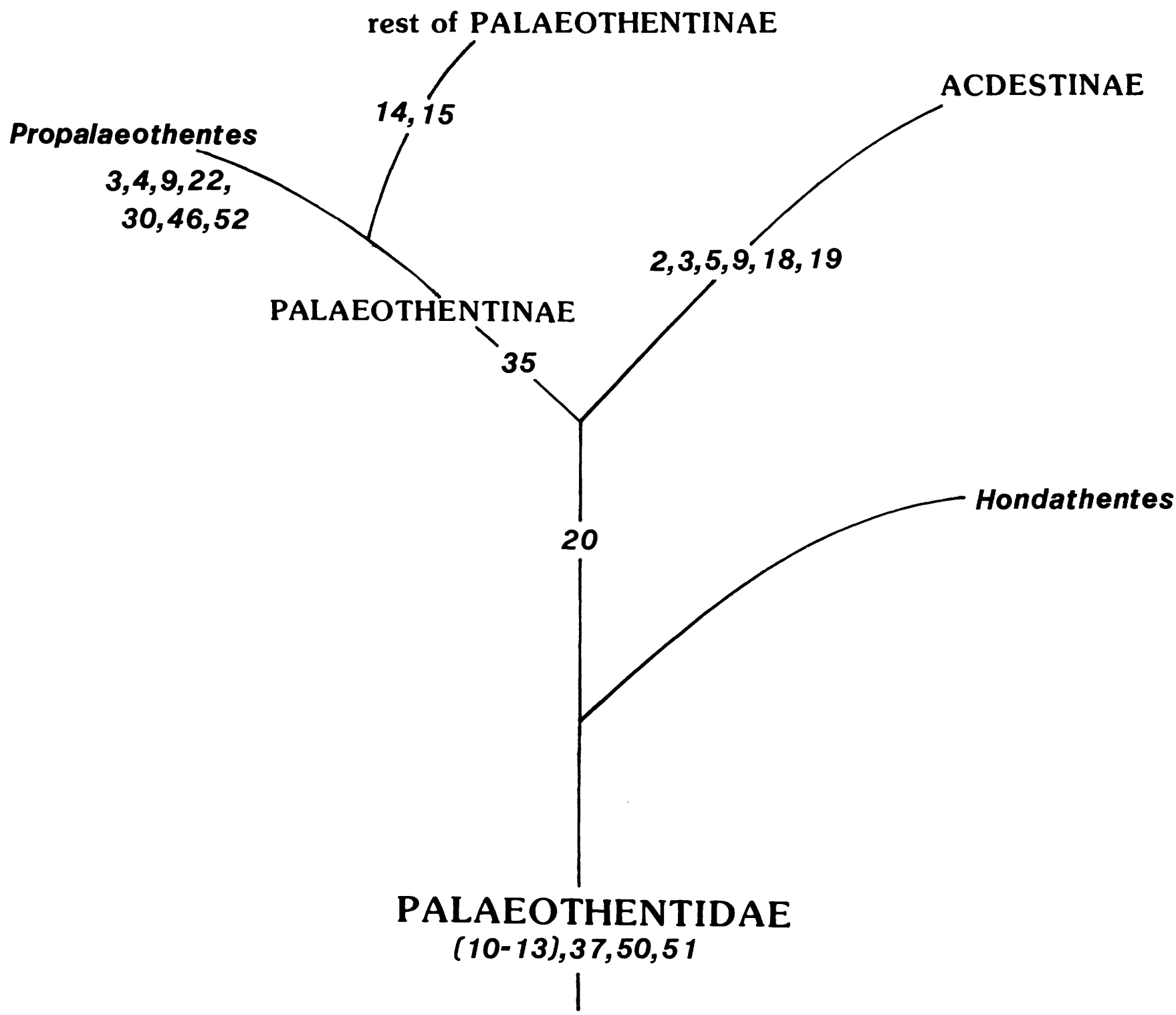

FIGURE 26-Principal clades of Palaeothentidae, showing differentiation of major subgroups of family using dental character analysis. Numbers refer to derived palaeothentid dental characters in Table 14.

Basin of Bolivia (Palaeothentes boliviensis) and at Cabeza Blanca in Chubut Province, Argentina (Carlothentes chubutensis, Pilchenia lucina, Acdestodon bonapartei, and Acdestoides praecursor). Thus, from the time of their initial appearance in the later Oligocene, the palaeothentid subfamilies Acdestinae and $\mathrm{Pa}-$ laeothentinae are both clearly distinct and well established. This fact indicates that the family experienced an unknown but probably considerable time of earlier evolution and differentiation.

Dental character analysis (Table 14) documents that the Palaeothentidae, including the incertae sedis genus Hondathentes, are united by: 1) $\mathrm{ml}$ with the termination of the protocristid confluent with the cristid obliqua at the metaconid or, if the protocristid is not attached to the metaconid, it is terminated anterior to it at an equivalent lingual position (character 50 in Table 14), such that the $\mathrm{ml}$ metaconid forms more a part of the talonid moiety of the tooth than a part of the trigonid; and 2) $M 2-4 / \mathrm{m} 2-4$ are each appreciably smaller than $M 1 / \mathrm{ml}$ and with invariable decrease in molar size posteriorly (character 51 in Table 14). No other derived dental characters of known po- larity unite all palaeothentids unless the incertae sedis genus Hondathentes is excluded from the family. Of all palaeothentid genera, Hondathentes possesses the greatest number of dental characters that we consider to be generalized for Palaeothentidae, having as well a suite of derived characters, some of which are unique to it (e.g., molar exodaenodonty). Additional derived characters, diagnostic of Palaeothentinae and Acdestinae, are not shared by Hondathentes and support the existence of three basic palaeothentid clades, of which Hondathentes is the most generalized: 1) Hondathentes; 2) Acdestinae; and 3) Palaeothentinae + Propalaeothentes; Figure 26). The Acdestinae and Palaeothentinae are united in sharing character 20; i.e., possession of a very oblique (less transverse) $\mathrm{m} 1$ paracristid, a feature lacking in Hondathentes. In Hondathentes the $\mathrm{ml}$ paracristid is oriented more sharply anterolingually-posterolabially (i.e., it is more transverse) and resembles much more closely the basic tribosphenic pattern manifest in teeth of more generalized marsupials, such as the Caenolestidae and Didelphidae. The two palaeothentid subfamilies form divergent branches, one united 


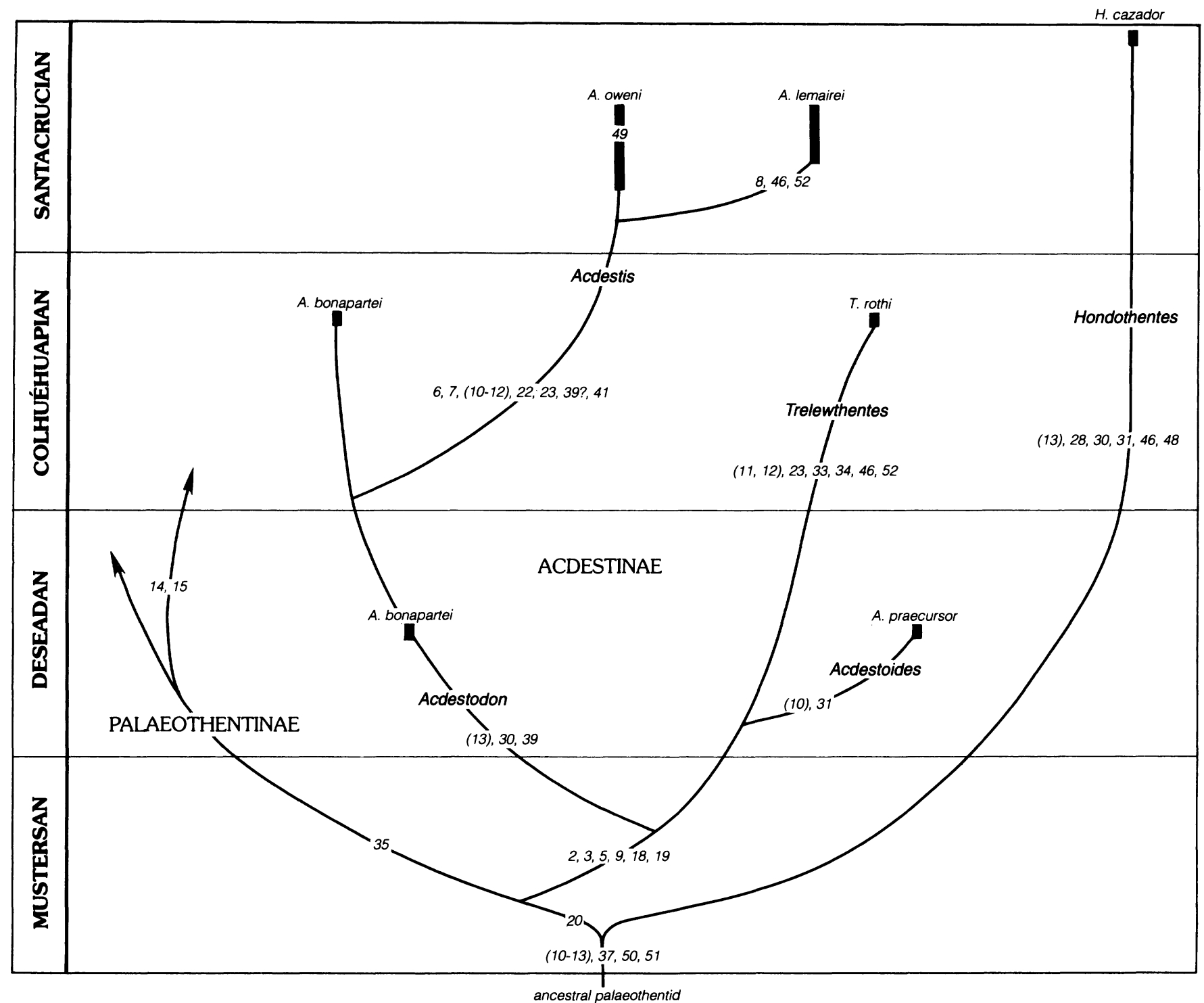

FIGURE 27-Phylogeny of the Acdestinae. Numbers refer to derived palaeothentid dental characters in Table 14. First lower molar trigonid structure morphologies in parentheses. Times of differentiation are conjectural but conform with data. Heavy solid lines depict temporal ranges of species.

by derived character 35 (Palaeothentinae + Propalaeothentes), and the other united by shared derived characters $2,3,5,9,18$, and 19 (Acdestinae).

The Acdestinae are united in: 1) the reduction and/or loss of p2; 2) having a very small p3 that is shorter than the height of the $\mathrm{m} 1$ paraconid; 3 ) having lost the anterobasal cusp on $\mathrm{p} 3$; and 4 ) having a very long $\mathrm{m} 1$ paracristid (characters $2,5,9,18$, 19-hereafter given only as numbers in brackets). In addition, the p3 talonid has become narrow, an advanced character [3] that was also developed (convergently) in two palaeothentine clades (Propalaeothentes, and "rest of Palaeothentinae").

The clade containing Deseadan-Colhuéhuapian Acdestodon and Santacrucian Acdestis is distinguished from the Acdestoides + Trelewthentes clade by loss of the $\mathrm{m} 2$ paraconid [30] and by considerable decrease in $\mathrm{m} 3$ area with respect to $\mathrm{m} 2$ area [39]. The Acdestoides + Trelewthentes clade split, Acdestoides developing a closed entoconid notch on $\mathrm{m} 2$ [31], a feature not seen in Trelewthentes. Trelewthentes instead developed a di- vergent combination of dental specializations. Some of those were convergent with morphological developments in other clades [23, 46], whereas others [33, 34] are unique for Palaeothentidae. The Acdestoides + Trelewthentes clade apparently went extinct in late Colhuéhuapian time. The relationship of Acdestoides to Trelewthentes is conjectural and is based solely upon the shared primitive retention of the $\mathrm{m} 2$ paraconid. It is perhaps equally likely that the very poorly known Acdestoides was an early descendant of the Acdestodon + Acdestis clade, the split with Acdestodon having occurred prior to loss of the $\mathrm{m} 2$ paraconid [30] in the latter genus. Unfortunately, nothing is known of $\mathrm{m} 1$ or $\mathrm{m} 3$ structure in Acdestoides.

Acdestodon bonapartei persisted into Colhuéhuapian time, at some stage in its history having probably given rise to closely similar Acdestis, the best known member of the Acdestinae (Figure 27). Acdestis is distinguished from Acdestodon by possession of four derived transient characters $[6,7,22,23]$ and of three variable characters $[10,11,12]$, to the exclusion of a fourth [13], 
that is present in Acdestodon. The variable characters (pertaining to $\mathrm{m} 1$ trigonid structure), though taxonomically valid for use in separating the genera Acdestis and Acdestodon on a morphologic basis, are distributed throughout the Palaeothentidae and are of doubtful polarity. The transient characters are variably present in some or all Acdestis and do not occur in Acdestodon. First known in this clade for Acdestis, the ratio of $\mathrm{m} 3 \mathrm{area} / \mathrm{m} 2$ area [39] cannot be calculated for Acdestodon and may have also been small (less than 0.6). Similarly, the great reduction of $\mathrm{M} 4 / \mathrm{m} 4$ [41] seen in Acdestis may have actually originated with Acdestodon, or may even have been a very early acdestine acquisition.

Acdestis oweni and A. lemairei represent the end products of the Acdestinae. Acdestis lemairei, with a minute, anteriorly canted p3 [8], overall smaller teeth [46], and a shallower mandible [52], is more derived than $A$. oweni; nonetheless, $A$. oweni and $A$. lemairei are very closely related species and differ largely in transient characters that form part of a continuum of variability too great for one species. Some younger specimens of $A$. oweni possess inwardly canted molar cusps [49]; however, the number of specimens is too few to suggest a divergent morphologic trend.

Trends in molar areas (Figures 28-30) and the ratio between the area of $\mathrm{m} 3$ to that of $\mathrm{m} 2$ (Figures 31,32 ) are important in understanding the nature of morphologic developments in the Palaeothentidae. Although these data are sparse for early Santacrucian time (that represented by the Pinturas Formation where sites are scattered stratigraphically and palaeothentids are rare), it seems clear that the areas of $\mathrm{m} 1$ and $\mathrm{m} 2$ in the earliest acdestines were generally about the same as those of later acdestine species and that the area of $\mathrm{m} 3$ was reduced dramatically, especially in its proportion to the area of $\mathrm{m} 2$ (Figures 31,32 ). This decrease in $\mathrm{m} 3$ area with respect to $\mathrm{m} 2$ area is a hallmark of subfamily Acdestinae and was manifested to its extreme in Acdestis lemairei. That this proportion might be a correlate of very small tooth size in general is belied by the very large $\mathrm{m} 3$ area/ $/ \mathrm{m} 2$ area ratios for the diminutive palaeothentines Palaeothentes minutus and $P$. pascuali, and the very small ratio in the largest of all the palaeothentids, Palaeothentes aratae.

The degree of overlap of areas of $\mathrm{m} 1$ and $\mathrm{m} 2$ for all Santacrucian Palaeothentidae are depicted in Figures 33 and 34. In general, there is good separation of values for molar areas among palaeothentids, the outstanding exceptions being considerable overlap in $\mathrm{m} \mathrm{l}$ area of the palaeothentine Palaeothentes lemoinei with that of the acdestine Acdestis oweni, and confluence of both with values for Acdestis lemairei. Collectively, Palaeothentes lemoinei and Acdestis oweni differ from each other in the acquisition or loss of 18 dental characters [2, 5-7, 9, 14-16, 19, $22,35,38-43,49]$ and are morphologically about as disparate from each other as are any other two palaeothentids. Strait et al. (1990) postulated that Palaeothentes lemoinei was a borderline faunivore-herbivore and that, in contrast, Acdestis oweni was frugivorous. However, $\mathrm{m} 1$ area overlap between Acdestis oweni and the slightly smaller and congeneric $A$. lemairei is matched by overlap or near overlap in a number of other gnathic features, including: mandibular depth [52] (Figure 35); p3 size and inclination [6-8]; $\mathrm{m} 1$ trigonid structure [10-12] (Figures 35, 41 ); $\mathrm{m} 2$ area (Figure 34); and the ratio of $\mathrm{m} 3 \mathrm{area} / \mathrm{m} 2$ area [39] (Figure 32). These data are strongly suggestive of an in situ gradual cladogenetic differentiation of $A$. lemairei from $A$. oweni, probably at some time during the early through middle Santacrucian.

The first three molars of Acdestis oweni are also interesting in that all appear to have decreased in area through time. Although overall size change was insignificant for $\mathrm{m} 1$ (Figure 36), that for $\mathrm{m} 2$ and $\mathrm{m} 3$ was dramatic both in the degree of change and in the temporal distribution of that change. The most abun- dant stratigraphically organized data are distributed from the upper part of the Pinturas Formation through most of the Santa Cruz Formation (sections at Monte Observación and Monte León). In Figures 34 and 37, it is seen that $\mathrm{m} 2$ in $A$. oweni shows a rather consistent decrease in observed range of area values through the early part of later Santacrucian time (temporal values $=$ about $66-83$ ), then the means of those values shift to about 50 percent larger mean areas in samples immediately above tuff unit 8 in the lower parts of the sections at Monte Observación and Monte León. The temporal distribution of area values above tuff unit 8 consists of a second rapid and marked decrease in $\mathrm{m} 2$ area but at a rate exceeding that indicated by data from beneath tuff unit 8 . The observed ranges of $\mathrm{m} 2$ areas for the samples immediately above the tuff are also significantly greater than those observed for any samples below it. A similar pattern is evident from the $\mathrm{m} 3$ data (Figure 38 ), but is documented by many fewer data.

Tuff unit 8 (Figure 39 ) is a relatively unaltered $1.50-2.00 \mathrm{~m}$ thick vitric tuff that is developed near the base of the Santa Cruz Formation at the coastal localities of Monte Observacion and Monte León and inland along the southern barranca of the Río Chalia. Sedimentologic and taphonomic evidence indicates that the deposit represents a single very major episode of pyroclastic deposition from volcanic sources in the Andean cordillera, some $300-350 \mathrm{~km}$ to the west. Bown and Anderson (manuscript) attributed the rapid $\mathrm{m} 2$ and $\mathrm{m} 3$ area changes in Acdestis oweni and like changes in $\mathrm{m} 1$ of the echimyid rodent Spaniomys to the rapid replacement of locally extinct populations of those animals by founder populations from outlying areas, populations that differed somewhat in their phenotypic constitutions from those of the recently defunct resident populations. Although the data are yet too few for convincing evidence of change in the stratigraphic representation of $\mathrm{m} 3 \mathrm{area} /$ $\mathrm{m} 2$ area (Figure 40), they do suggest that changes in the distribution of that ratio may also have been affected by deposition of tuff unit 8 and possibly as well by geological event-controlled lacunae within the Pinturas Formation.

Bown and Larriestra (1990) demonstrated that significant episodes of erosion during Pinturas time were triggered by (and preceded stratigraphically by) periods of unusually high rates of pyroclastic deposition. Because Deseadan through Santacrucian rocks of Patagonia are volumetrically dominated by material of pyroclastic origin, including many massive eolian tuffs, it appears likely to us that such stochastic catastrophic reductions in population sizes (and even local and regional extinctions resulting from rapid pyroclastic deposition) profoundly influenced the course of evolution of the Palaeothentidae and other mammals there throughout the middle Tertiary.

Finally, although data are too few to be definitive, the proportionate representation of $\mathrm{ml}$ trigonid type in Acdestis oweni also may have changed at geologic event boundaries in the Pinturas and Santa Cruz Formations (Table 16; Figure 41). As inferred earlier, variable representation in different palaeothentid species of the four types of $\mathrm{m} 1$ trigonid structures may reflect family level long-term genotypic plasticity in this aspect of dental morphology-one manifested in the phenotypic disappearance and reappearance of one or more of the variant types in differing proportions, at different times, and in phylogenetically distant lineages. The combined geological and evolutionary evidence therefore suggests a strong causal link between active, at times catastrophic, geological phenomena and sudden changes in dental character distribution and even species representation in small mammals during Santacrucian time. These changes mirror those seen adjacent to faunal "biohorizon" boundaries also marked by differing sedimentologic parameters in the lower Eocene of Wyoming (Bown and Kraus, in press). 


\section{Distribution of $\mathrm{m} 1$ area in Palaeothentidae}

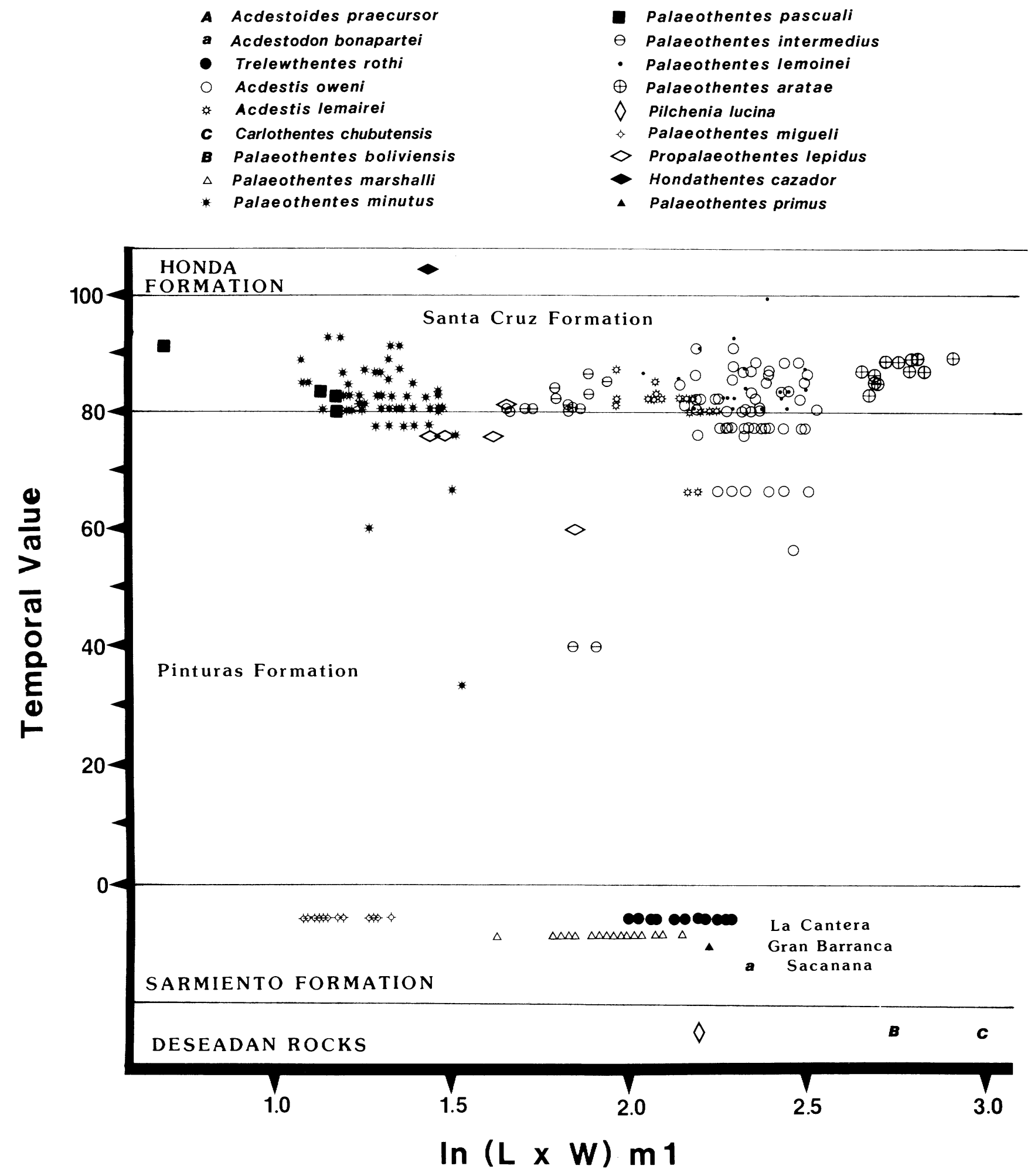

FIGURE 28-Graph showing time-stratigraphic distribution of natural logarithm of $\mathrm{ml}$ area (abscissa) in Deseadan-Santacrucian Palaeothentidae from various Deseadan rocks, and the Sarmiento, Pinturas, Santa Cruz, and Honda Formations. 


\section{Distribution of $\mathrm{m} 2$ area in Palaeothentidae}

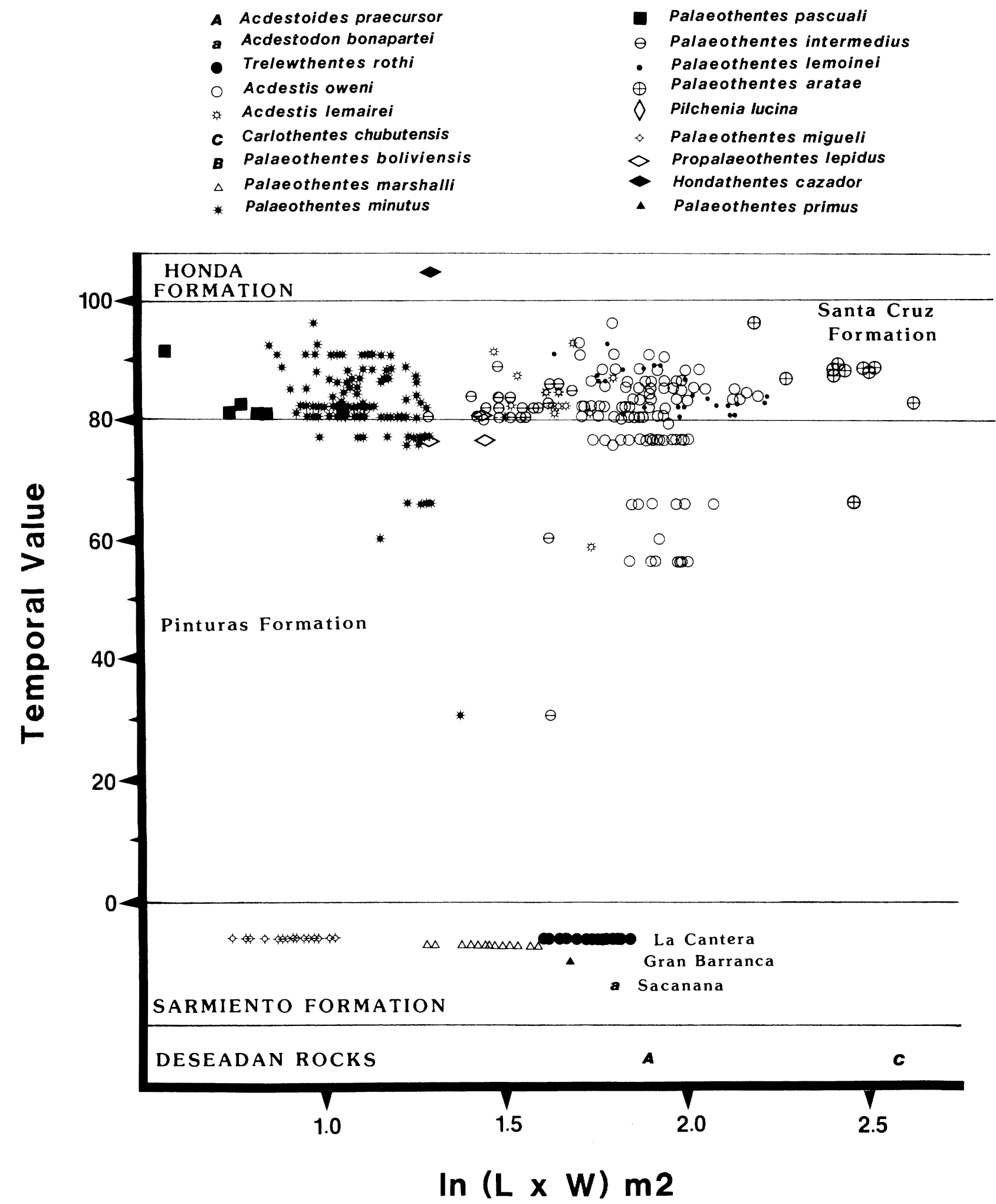

FIGURE 29-Graph showing time-stratigraphic distribution of natural logarithm of $\mathrm{m} 2$ area (abscissa) in Deseadan-Santacrucian Palaeothentidae from various Deseadan rocks, and the Sarmiento, Pinturas, Santa Cruz, and Honda Formations. 


\section{Distribution of $\mathrm{m} 3$ area in Palaeothentidae}
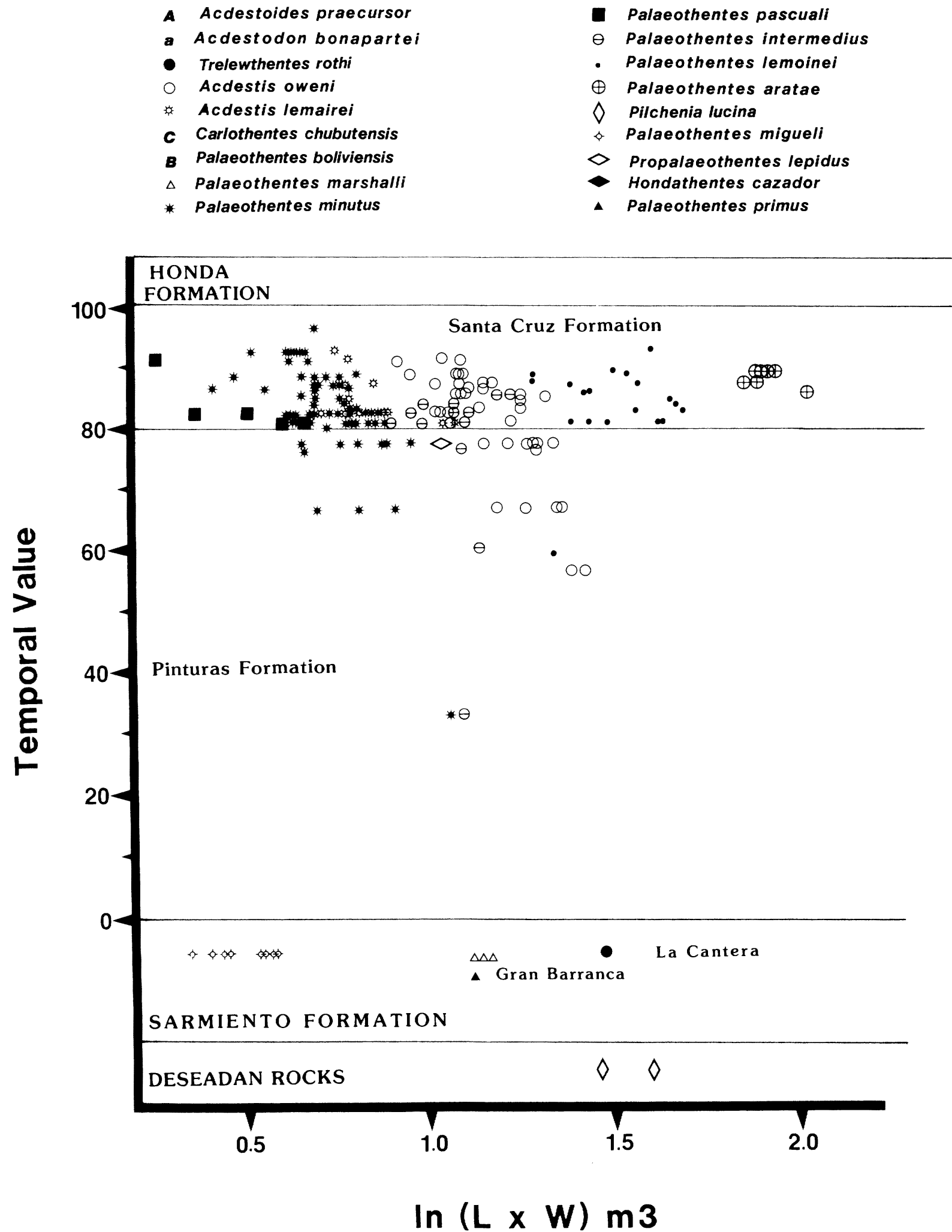

FIGURE 30-Graph showing time-stratigraphic distribution of natural logarithm of $\mathrm{m} 3$ area (abscissa) in Deseadan-Santacrucian Palaeothentidae from various Deseadan rocks, and the Sarmiento, Pinturas, and Santa Cruz Formations. 


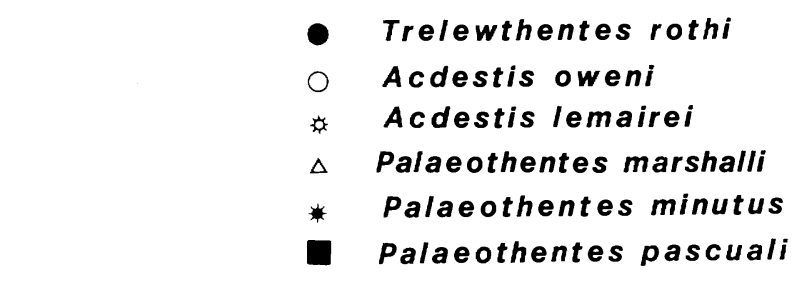

$\Theta$ Palaeothentes intermedius

- Palaeothentes lemoinei

$\oplus$ Palaeothentes aratae

$\diamond$ Pilchenia lucina

\& Palaeothentes migueli

$\diamond$ Propalaeothentes lepidus

- Palaeothentes primus

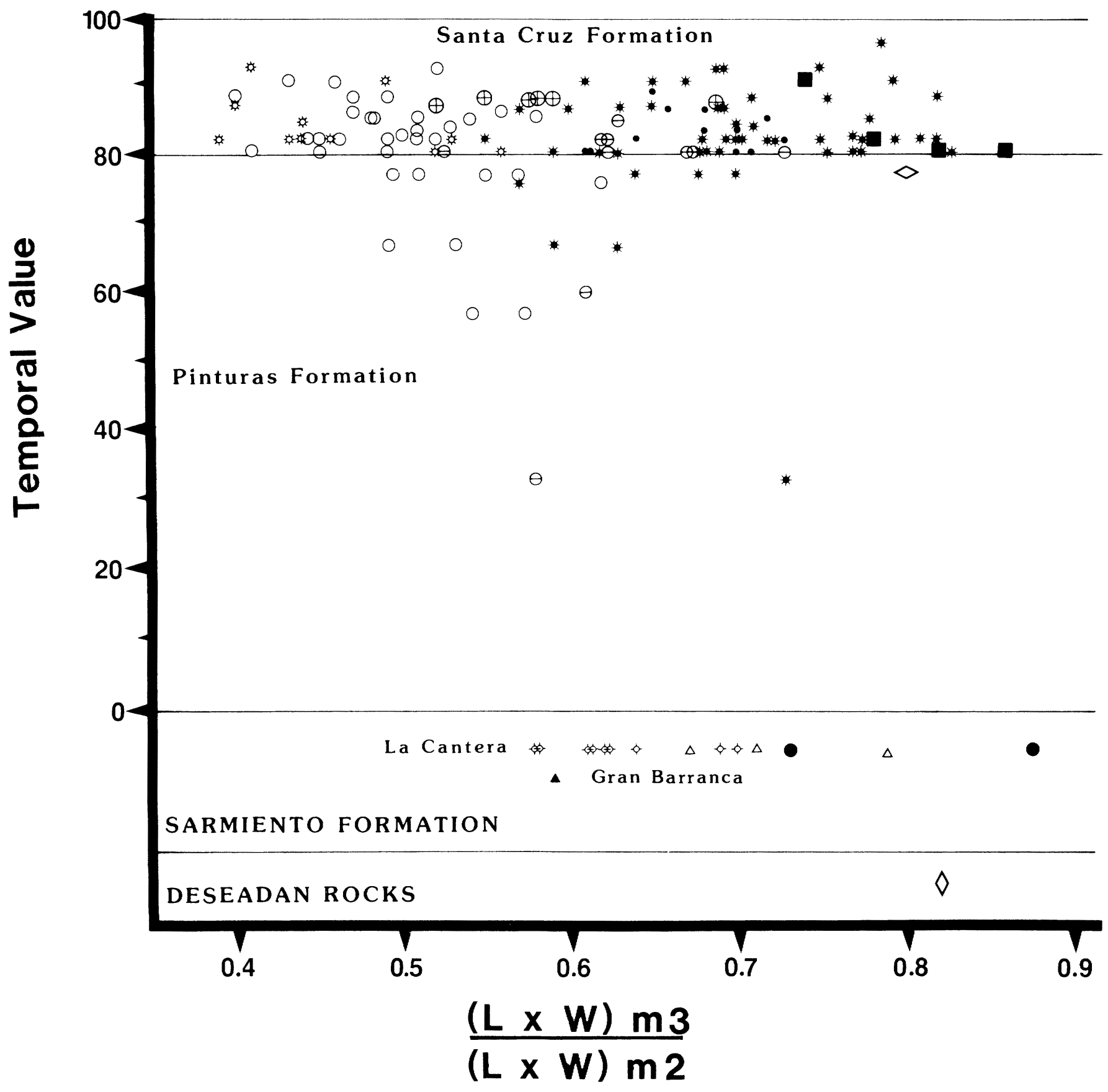

FIGURE 31-Graph showing time-stratigraphic distribution of the natural logarithm of the ratio of $\mathrm{m} 3$ area to $\mathrm{m} 2$ area in Deseadan-Santacrucian Palaeothentidae from various Deseadan rocks, and the Sarmiento, Pinturas, and Santa Cruz Formations. Two data points for Trelewthentes roth $\mathrm{i}$. gen. and sp. were obtained by obtaining the ratio of the area of the sole specimen of $\mathrm{m} 3$ to the areas of the largest and smallest specimens of $\mathrm{m} 2$ ( $\mathrm{m} 2$ and $\mathrm{m} 3$ are known only from isolated teeth). 

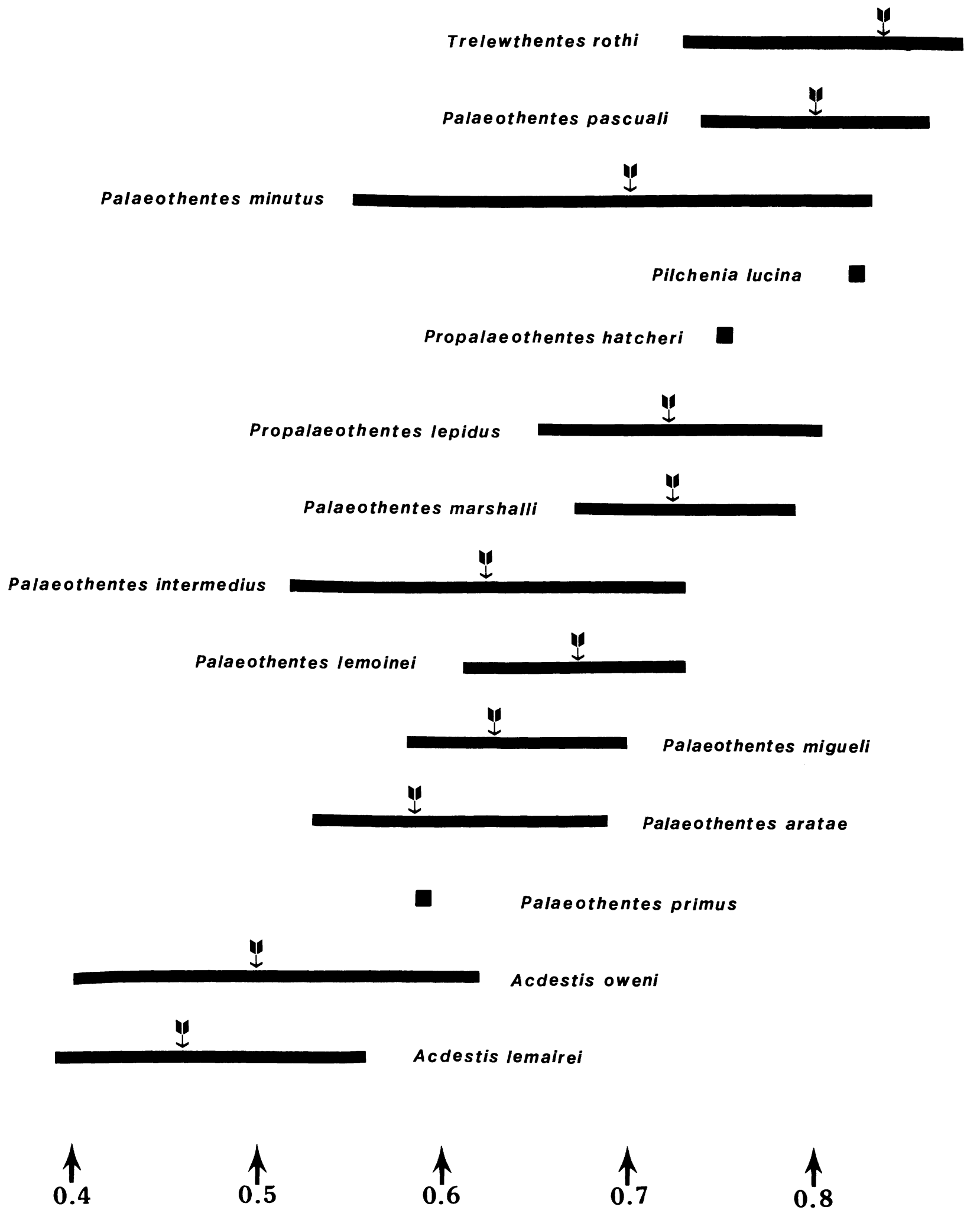


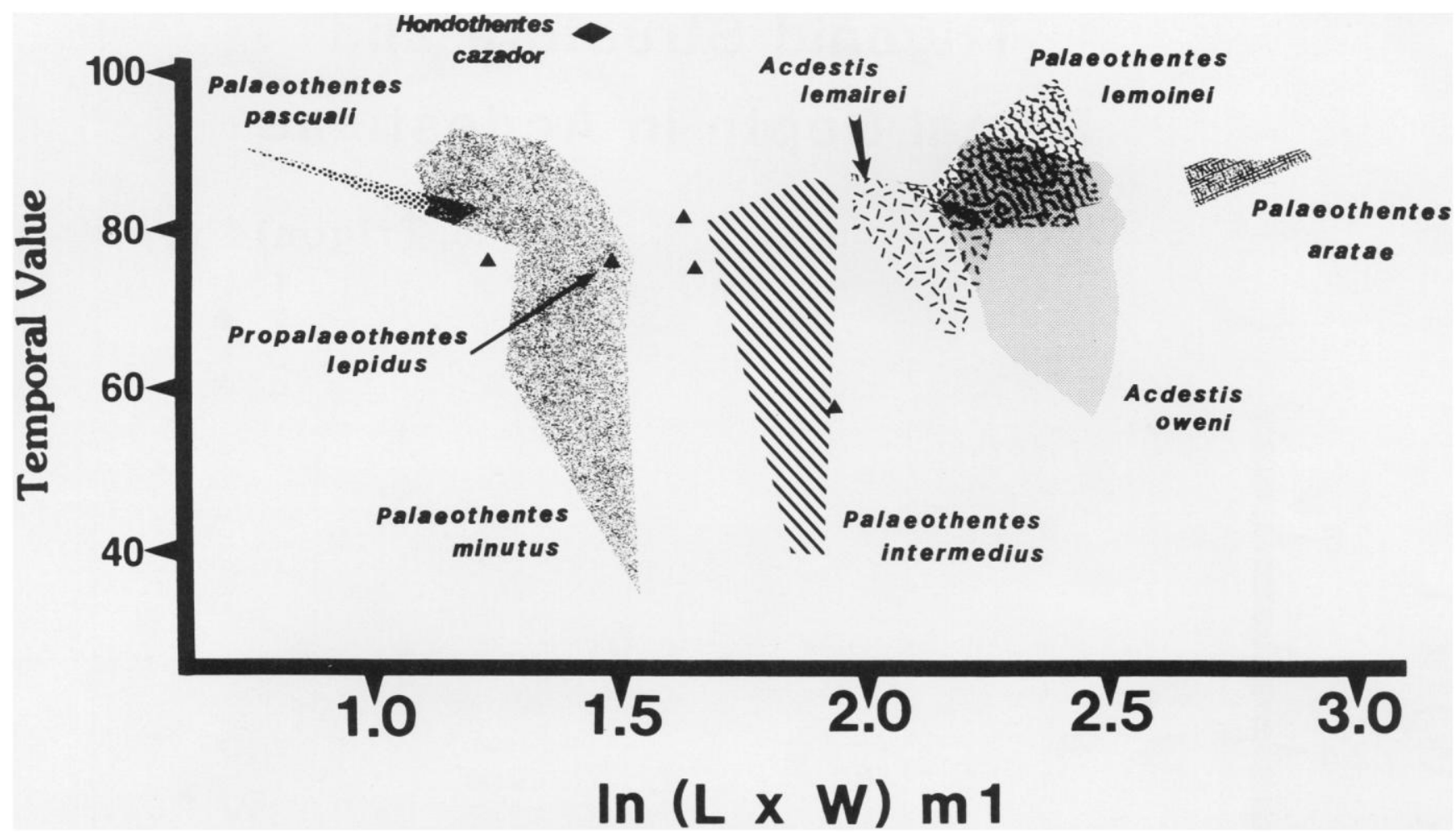

FIGURE 33-Diagram showing overlap in distribution of $\log \mathrm{n}$ values of $\mathrm{ml}$ area in Santacrucian Palaeothentidae. Ordinate is temporal value calculated for localities in sections of Santacrucian age; abscissa is $\ln (\mathrm{L} \times \mathrm{W}) \mathrm{ml}$. Shaded areas obtained by connecting extreme high and low values in observed ranges of molar area.

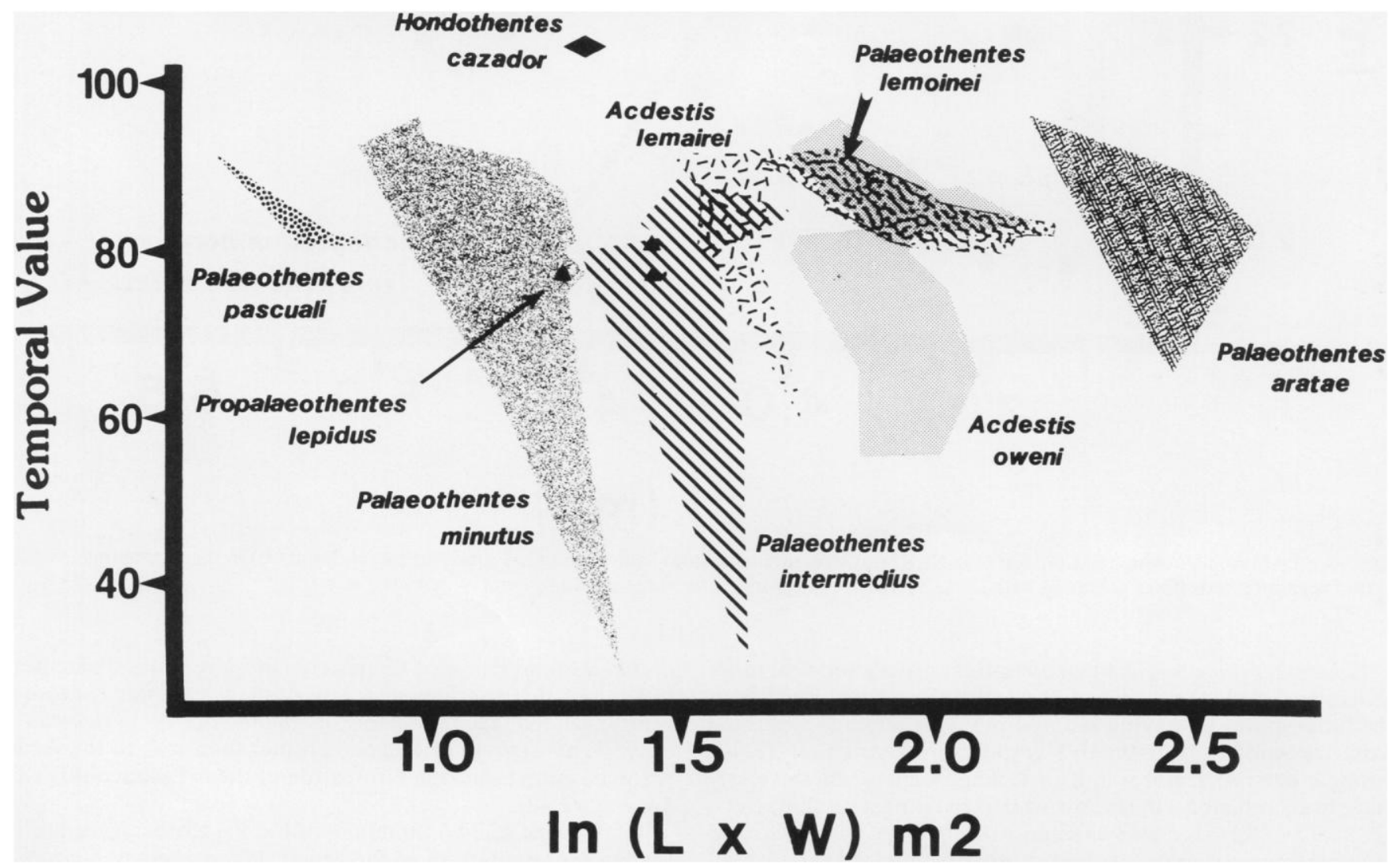

FIGURE 34-Diagram showing overlap in distribution of $\log n$ values of $m 2$ area in Santacrucian Palaeothentidae. Ordinate is temporal value calculated for localities in sections of Santacrucian age; abscissa is $\ln (\mathrm{L} \times \mathrm{W}) \mathrm{m} 2$. Shaded areas obtained by connecting extreme high and low values in observed ranges of molar areas. 


\section{Trigonid Structure and Ramal Depth in Acdestinae}

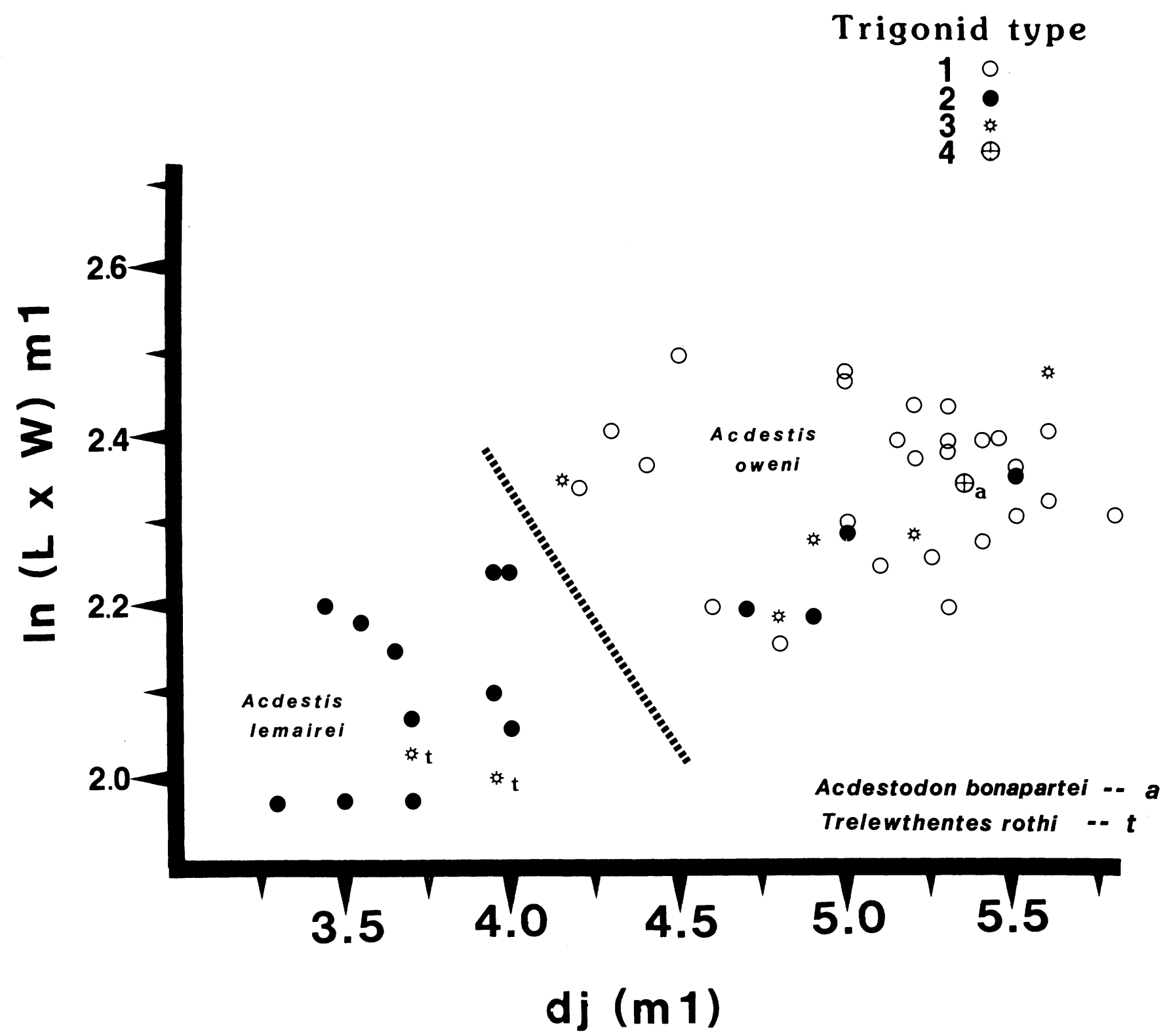

FIGURE 35-Graph showing relationship of $\mathrm{m} 1$ trigonid structure to natural logarithm of $\mathrm{m} 1$ area and ramal depth (dj) in the Acdestinae. Oblique line separates acdestines grouping with Acdestis oweni Ameghino from those grouping with $A$. lemairei $\mathrm{n}$. sp.

Palaeothentinae. - The Palaeothentinae are a somewhat more generalized clade than the Acdestinae and are distinguished from the latter group by having $\mathrm{m} 2$ and $\mathrm{m} 3$ with talonids separated from trigonids by a distinctive vespiform construction ([35]a single derived feature) and in lacking (at least at this early stage in their history) the following derived acdestine characters: [2, 3, 5, 9, 18, 19]. Palaeothentes, Carlothentes, Pilchenia, and Propalaeothentes are united in sharing character [35], and all acdestines and the incertae sedis genus Hondathentes lack it. Therefore, the Acdestinae are more recently related to Hon- dathentes than either of the latter clades are to the Palaeothentinae, and the enigmatical genus Propalaeothentes is more recently related to the clade Palaeothentes + Pilchenia + Carlothentes (=rest of Palaeothentine) than it is to the Acdestinae, despite its lacking bifurcation of the $\mathrm{m} 1$ paraconid (Table 14; Figure 42).

The earliest known members of the Palaeothentinae are Deseadan representatives of the genera Palaeothentes, Carlothentes, and Pilchenia. Palaeothentes is known from one Deseadan specimen, $P$. boliviensis, from the Salla-Luribay Basin of Bolivia 


\section{Acdestis oweni}

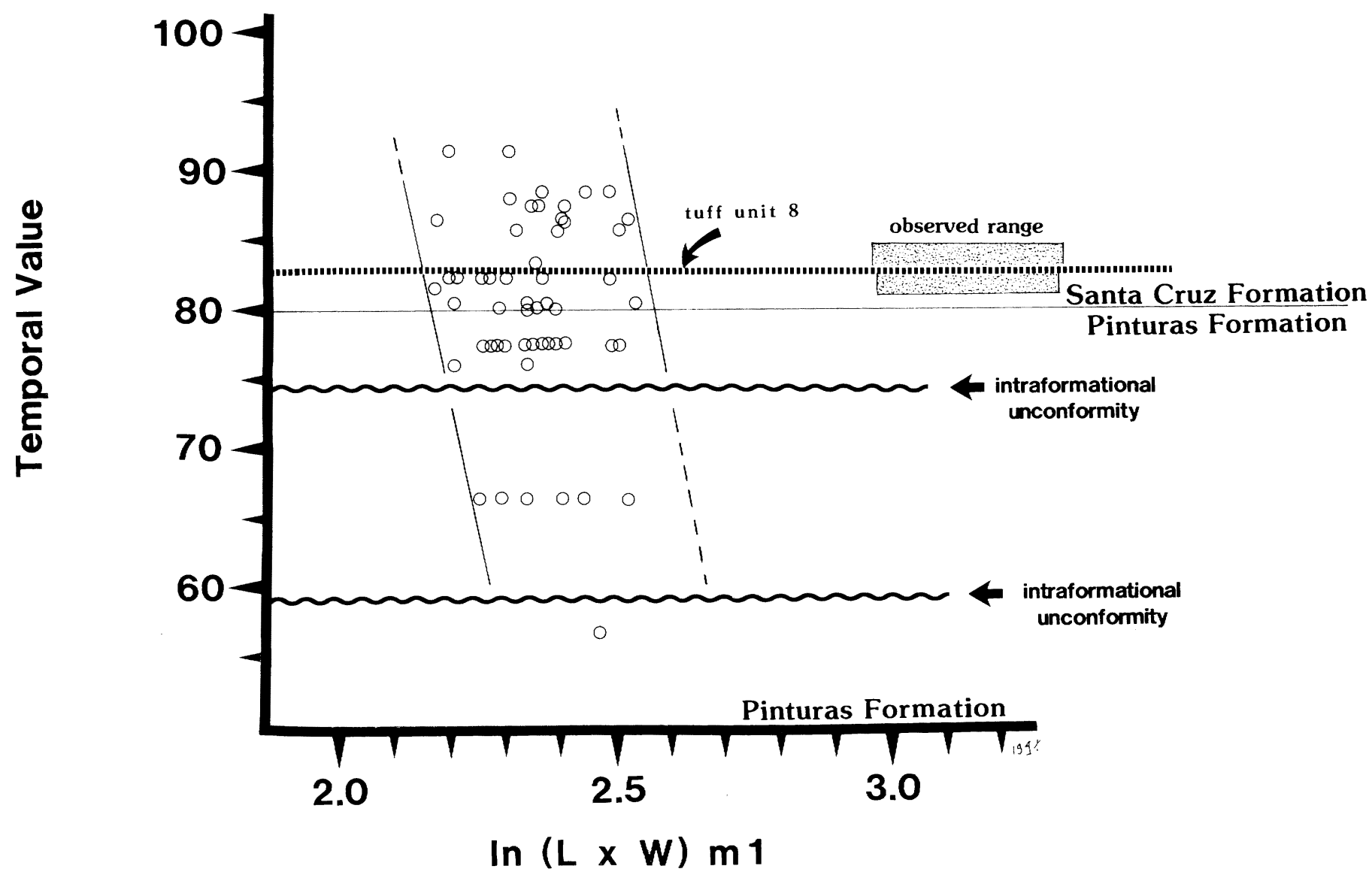

FIGURE 36-Time-stratigraphic distribution of $\mathrm{m} 1$ area in Acdestis oweni Ameghino from the Pinturas and Santa Cruz Formations.

(Patterson and Marshall, 1978; Marshall, 1980). Carlothentes chubutensis is known from its type specimen only and Pilchenia lucina is known from but two specimens; both taxa are probably from Cabeza Blanca. Carlothentes chubutensis is excluded from the Palaeothentes + Pilchenia clade by retention of a short $\mathrm{m} 1$ paracristid and in possessing the specialized characters [24, 26]. Palaeothentes and Pilchenia are united by three derived features of the first lower molar; 1 ) an $\mathrm{ml}$ paraconid that is shorter than the protoconid [14], 2) a bifurcated $\mathrm{ml}$ paraconid [15], and 3) a long $\mathrm{m} 1$ paracristid [18]; the first two are characters that Marshall (1980) correctly postulated to be basic derivations of the Palaeothentes clade (Marshall, 1980, included Pilchenia in his construct of Palaeothentes).

Pilchenia lucina, unlike Palaeothentes, is unusual in its early possession of a suite of highly derived dental characters. For example, although Pilchenia primitively retains a metaconid on $\mathrm{m} 2$ it possesses the following derived characters: the $\mathrm{m} 1$ paraconid is very deeply bifurcated [17]; the $\mathrm{m} 1$ paracristid is quite long [18]; the $\mathrm{ml}$ protocristid is transversely narrow [21]; $\mathrm{ml}$ and $m 2$ have trenchant entoconids [29]; the $m 2$ entoconid is deeply twinned [32]; and m l-3 (uniquely among palaeothentids) have crenulated enamel [47]. Although Pilchenia shares type 4 trigonid structure with its collateral relative Carlothentes chubutensis (from the same locality) and both retain the $\mathrm{m} 2$ paraconid, the latter taxon primitively retains a short paracristid, lacks the advanced dental specializations seen in $P$. lucina, and has developed some of its own dental peculiarities [24, 26]. Except for Propalaeothentes, Carlothentes is, then, the most generalized known member of the Palaeothentinae.

Genus Palaeothentes is a large clade that is readily separated from Pilchenia by the derived loss of the $\mathrm{m} 2$ paraconid [30], primitive lack of the assemblage of dental specializations unique to Pilchenia lucina $[17,21,29,32,47]$, and development of a host of additional specializations that characterize individual species of Palaeothentes (Figure 42). Early in its history, the Palaeothentes clade split into two groups of species; the first typified by middle sized and very large forms with highly generalized dentitions (Palaeothentes boliviensis, $P$. primus, and $P$. aratae), and the second containing the six most highly derived species of Palaeothentes ( $P$. marshalli, $P$. migueli, $P$. intermedius, $P$. lemoinei, $P$. minutus, and $P$. pascuali). Two groups make up the early generalized species of Palaeothentes. In the first, $P$. boliviensis developed a transversely very narrow, oblique $\mathrm{m} 1$ protocristid $[21,22]$ in conjunction with a shortening of the $m 1$ talonid [25]. The first of these characters [21] formed convergently with similar developments in the Pilchenia lineage, whereas the latter two $[22,25]$ are unique to the subfamily. The second early generalized Palaeothentes group includes the Colhuéhuapian species $P$. primus and its perhaps descendant species, Santacrucian $P$. aratae. Palaeothentes primus and $P$. aratae 


\section{Acdestis oweni}

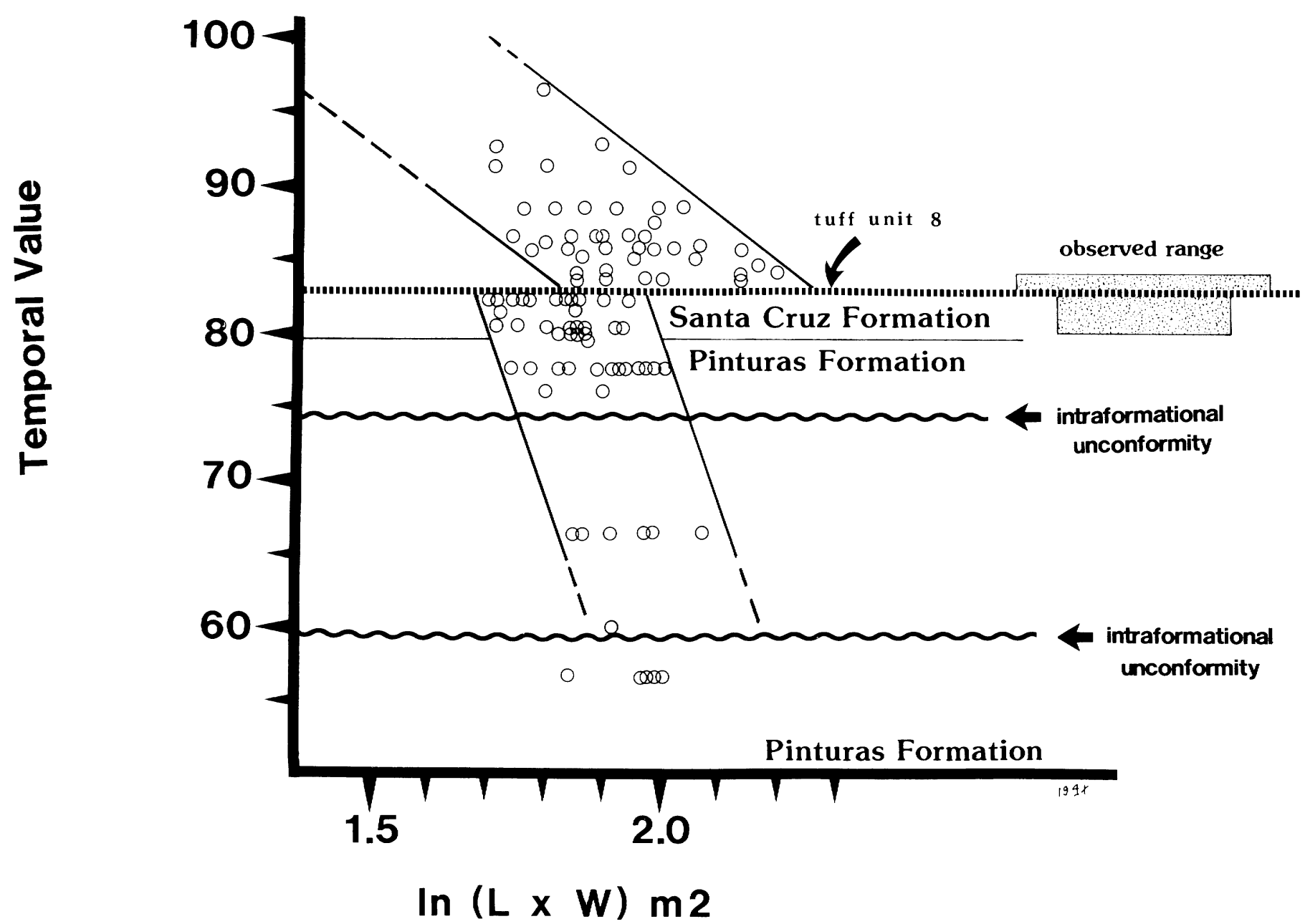

FIGURE 37 -Time-stratigraphic distribution of $\mathrm{m} 2$ area in Acdestis oweni Ameghino from the Pinturas and Santa Cruz Formations.

share a very anterolabially-posterolingually oblique $\mathrm{ml}$ protocristid [23] and a very small $\mathrm{m} 3 \mathrm{area} / \mathrm{m} 2$ area ratio [39], the latter character being convergent with an early and fundamental development in the Acdestinae. Palaeothentes primus and the much larger $P$. aratae diverged through the development of independent acquisitions, teeth of $P$. primus becoming smaller [46] and set in a shallower mandible [52], and p3 losing its anterobasal cusp [9]. In contrast, $P$. aratae retained the anterobasal p3 cusp and maintained the large size of all earlier palaeothentids but reduced the posterior breadth of p3 [3], developed a distinctive anterior mure on the $\mathrm{ml}$ entoconid [27], greatly simplified and reduced the size of $\mathrm{m} 4$ [41] (also convergent with Acdestinae), and developed incipiently trenchant molars [42]the last in parallel with all other species of Palaeothentes, excepting $P$. primus and $P$. boliviensis.

The more advanced species of Palaeothentes, on the other hand, are united in sharing a narrow p3 talonid [3], an $\mathrm{m} 1$ paraconid that is deeply bifurcated [16], at least incipiently trenchant molars [42], and in having much smaller tooth size [46]. This clade, containing all of the best known and most abundant representatives of the Palaeothentinae, also split very early in its history into two groups, each with three species. One of these contains the closely allied Colhuéhuapian species $P$. marshalli and $P$. migueli together with Santacrucian $P$. intermedius, and the other consists of Santacrucian Palaeothentes lemoine $i$ and the considerably smaller Santacrucian $P$. minutus and $P$. pascuali. The $P$. intermedius $-P$. marshalli- $P$. migueli line is united in having $\mathrm{p} 3$ slightly shorter than the elevation of the $\mathrm{m} 1$ paraconid [4] (a derived feature) and in the early decrease in both molar size and mandibular depth $[46,52]$. Palaeothentes intermedius, aside from a decrease in body size, remained fairly generalized in retaining a shallow $\mathrm{m} 1$ paraconid bifurcation [15] and a moderate $\mathrm{m} 3$ area $/ \mathrm{m} 2$ area [38]. Convergent with the $P$. lemoinei- $P$. minutus $-P$. pascuali lineage, the $\mathrm{M} 1$ in $P$. intermedius developed a lingually expanded hypocone platform [40].

Palaeothentes marshalli and $P$. migueli are united and distinct from $P$. intermedius in possessing an $\mathrm{ml}$ paraconid that is very deeply bifurcated [17] and in having considerably smaller teeth [46] and a shallower mandible [52]. Palaeothentes marshalli is distinct from $P$. migueli in retaining a much larger tooth size and in the development of a somewhat anterolabially-posterolingually oblique $\mathrm{m} 1$ protocristid. Palaeothentes migueli is fur- 


\section{Acdestis oweni}

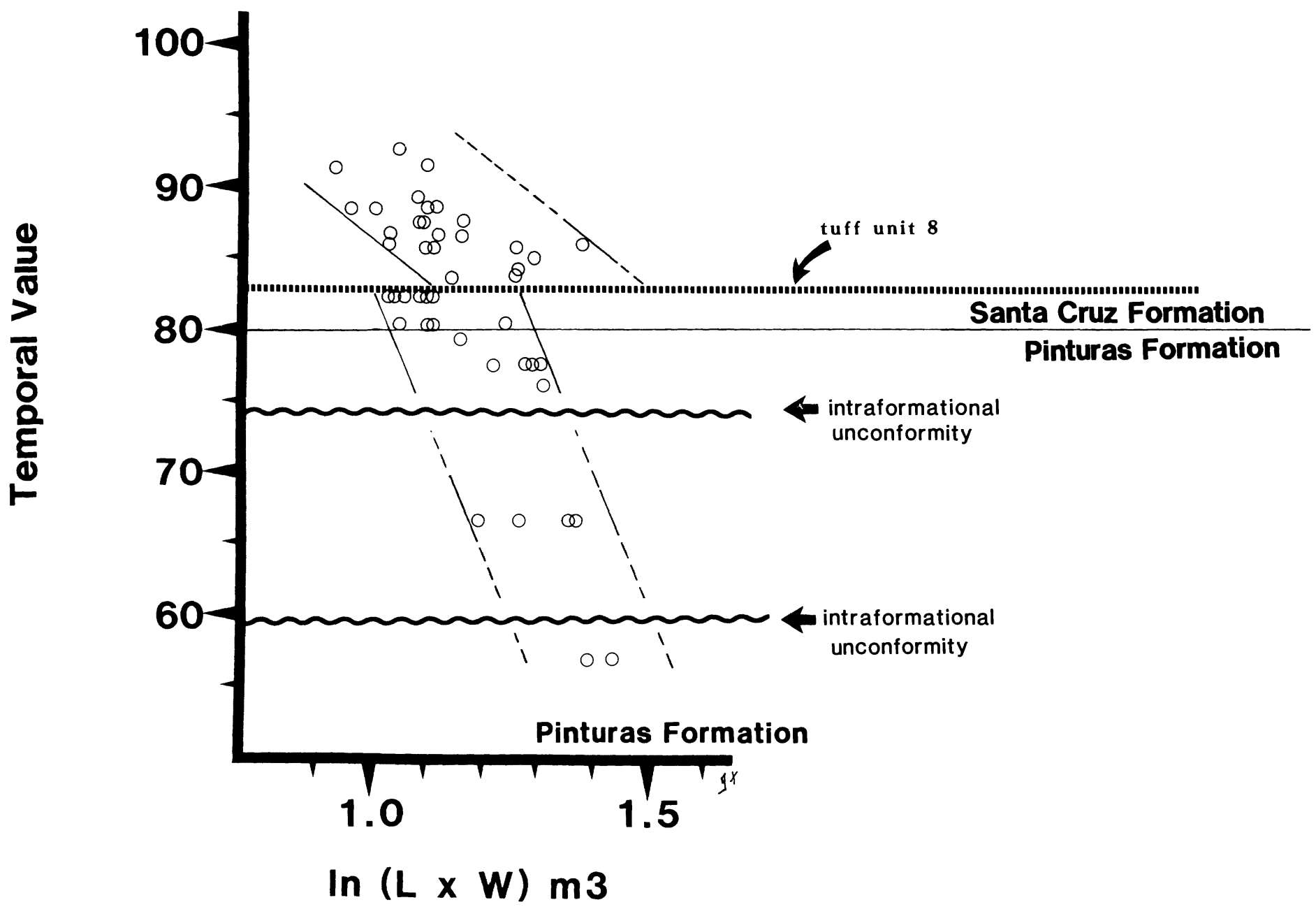

Figure 38-Time-stratigraphic distribution of m3 area in Acdestis oweni Ameghino from the Pinturas and Santa Cruz Formations.

ther characterized by a decrease in proportionate $\mathrm{m} 3$ area [38] and a vast reduction in molar size and mandibular depth [46, 52]. It is interesting that although Palaeothentes marshalli and $P$. migueli share the very deep $\mathrm{m} 1$ paraconid bifurcation with Deseadan Pilchenia lucina (and it is a feature unique to those species of Palaeothentes), they are separated from $P$. lucina by a long and different heritage, including acquisition of numerous derived characters $[3,4,30,42,46,52]$. The very deep bifurcation of the $\mathrm{m} 1$ paraconid was then another independent, convergent development in separate palaeothentine lineages.

The Palaeothentes lemoinei-P. minutus-P. pascuali lineage is distinct from that of Palaeothentes intermedius-P. marshalli$P$. migueli in having acquired a lingually expanded M1 hypocone platform [40] and at least moderately trenchant molars [43] and in retaining a relatively tall p3. Palaeothentes lemoinei is generalized in retaining relatively large tooth size and as many as three varieties of $\mathrm{ml}$ trigonid structure [10-12]. It is derived with respect to $P$. minutus and $P$. pascuali in possessing a very anterolabially-posterolingually oblique $\mathrm{m} 1$ protocristid [23] and in reduction in $\mathrm{m} 3$ area relative to that of $\mathrm{m} 2$ [38]-the latter character is held convengently with Palaeothentes intermedius and $P$. migueli.

Trends toward smaller and more trenchant molars, manifest since the separation of the $P$. lemoinei clade from the $P$. boliviensis- $P$. primus $-P$. aratae clade, were continued in the $P a$ laeothentes minutus $-P$. pascuali clade. In addition, those species share very narrow $\mathrm{m} 2$ and $\mathrm{m} 3$ [36] and much shallower mandibles [52]. Palaeothentes minutus retains a somewhat anterolabially-posterolingually oblique $\mathrm{m} 1$ protocristid [22], a condition that is generalized with respect to the more oblique $\mathrm{m} 1$ protocristids in most $P$. lemoinei and all $P$. pascuali. Palaeothentes pascuali manifests the smallest, most trenchant, and relatively narrowest teeth and the shallowest mandible of all palaeothentids [23, 45, 46, 52].

The lower first molar in Palaeothentes pascuali possesses type 3 trigonid structure [12], a condition shared by some specimens of the closely related $P$. lemoinei but not by its otherwise closest morphological relative, $P$. minutus. Because of their sporadic temporal and taxonomic distributions, the four variant trigonid morphologies of $\mathrm{ml}$ are considered to be transient, variable (plastic) characters that may have manifested themselves at any time and in any proportion to one another. Used as a strict dental character given equal weight with all others, Palaeothentes pascuali must have been derived from the vastly larger $P$. lemoinei because $P$. minutus, with which it shares far more characters, lacks type $3 \mathrm{~m} 1$ trigonids [12]. We prefer to link the 


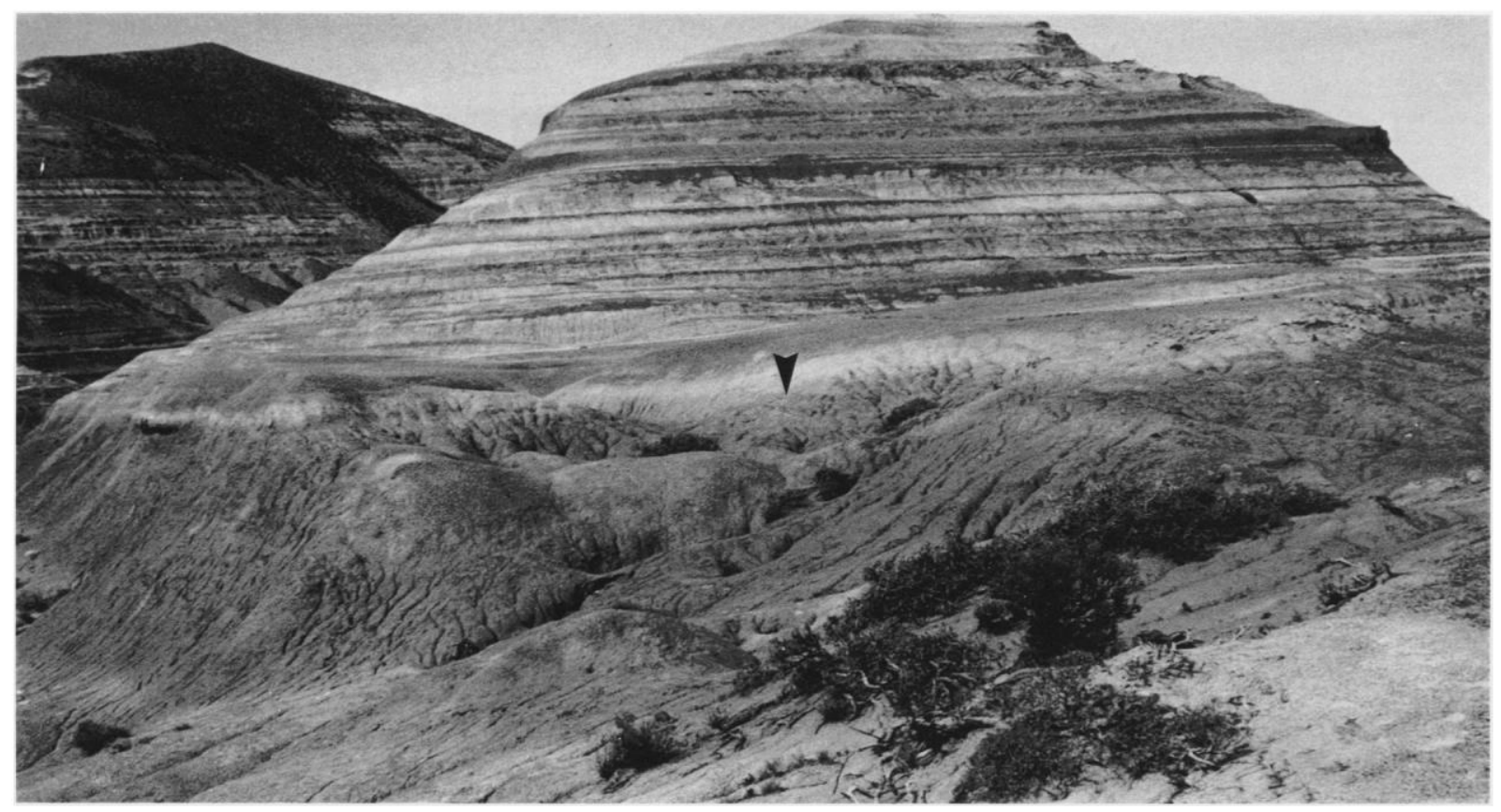

Figure 39-Tuff unit 8 near base of Santa Cruz Formation at Monte Observación. At this site, bed is $1.65 \mathrm{~m}$ thick. Arrow denotes level of estaca \#7. View approximately to southeast.

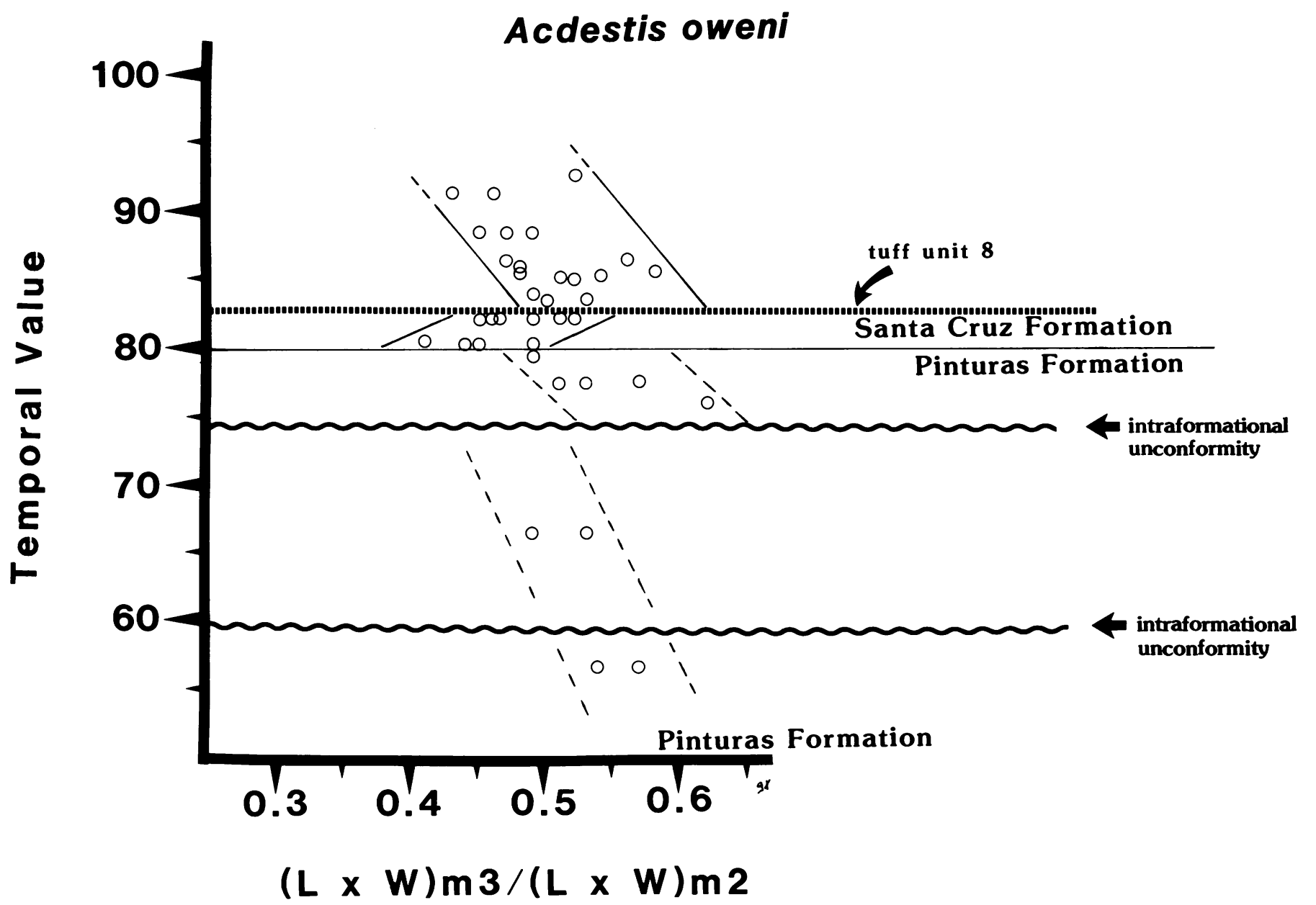

FIGURE 40-Time-stratigraphic distribution of ratio of $\mathrm{m} 3$ area to $\mathrm{m} 2$ area in Acdestis oweni Ameghino. 
TABLE 16-Time-stratigraphic percent representation of $\mathrm{ml}$ trigonid structure in Acdestis oweni Ameghino in geological event bounded sequences (A-D) in the Santacrucian Pinturas and Santa Cruz Formations. TV $=$ temporal value; types $1-3=\mathrm{m} 1$ trigonid structure types discussed in text.

\begin{tabular}{cllll}
\hline \hline Sequence & \multicolumn{3}{c}{ Trigonid type and percent representation } \\
\hline $\mathrm{D}$ & type $1=68.7 \%$ & type $2=25.0 \%$ & type $3=6.3 \%$ & $\mathrm{~N}=16$ \\
$\mathrm{C}$ & type $1=53.3 \%$ & type $2=26.6 \%$ & type $3=20.0 \%$ & $\mathrm{~N}=15$ \\
$\mathrm{~B}$ & type $1=67.0 \%$ & type $2=33.0 \%$ & type $3=0.0 \%$ & $\mathrm{~N}=12$ \\
$\mathrm{~A}$ & type $1=67.0 \%$ & type $2=16.5 \%$ & type 3=16.5\% & \\
\hline
\end{tabular}

$\mathrm{A}=$ Pinturas Formation; $\mathrm{TV}=60.0-74.8 ; \mathrm{B}=$ Pinturas Formation; $\mathrm{TV}=74.8-80.0 ; \mathrm{C}=$ Santa Cruz Formation; $\mathrm{TV}=80.0-83.0 ; \mathrm{D}=\mathrm{Santa}$ Cruz Formation; TV $=83.0-92.0$.

\section{Trigonid Structure in Acdestis}

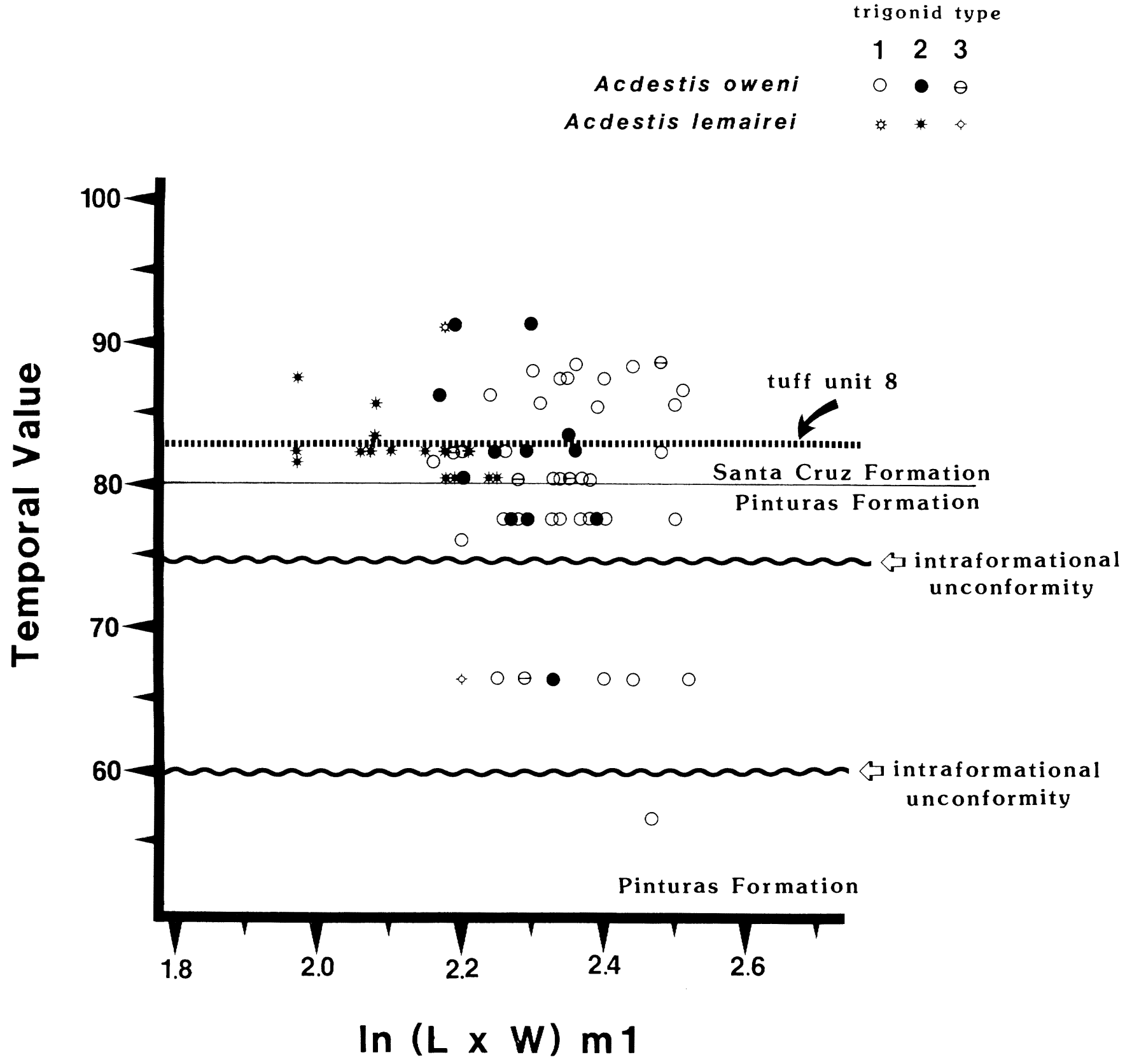

FIGURE 41 -Time-stratigraphic distribution of $\mathrm{m} 1$ trigonid structure in Acdestis. 


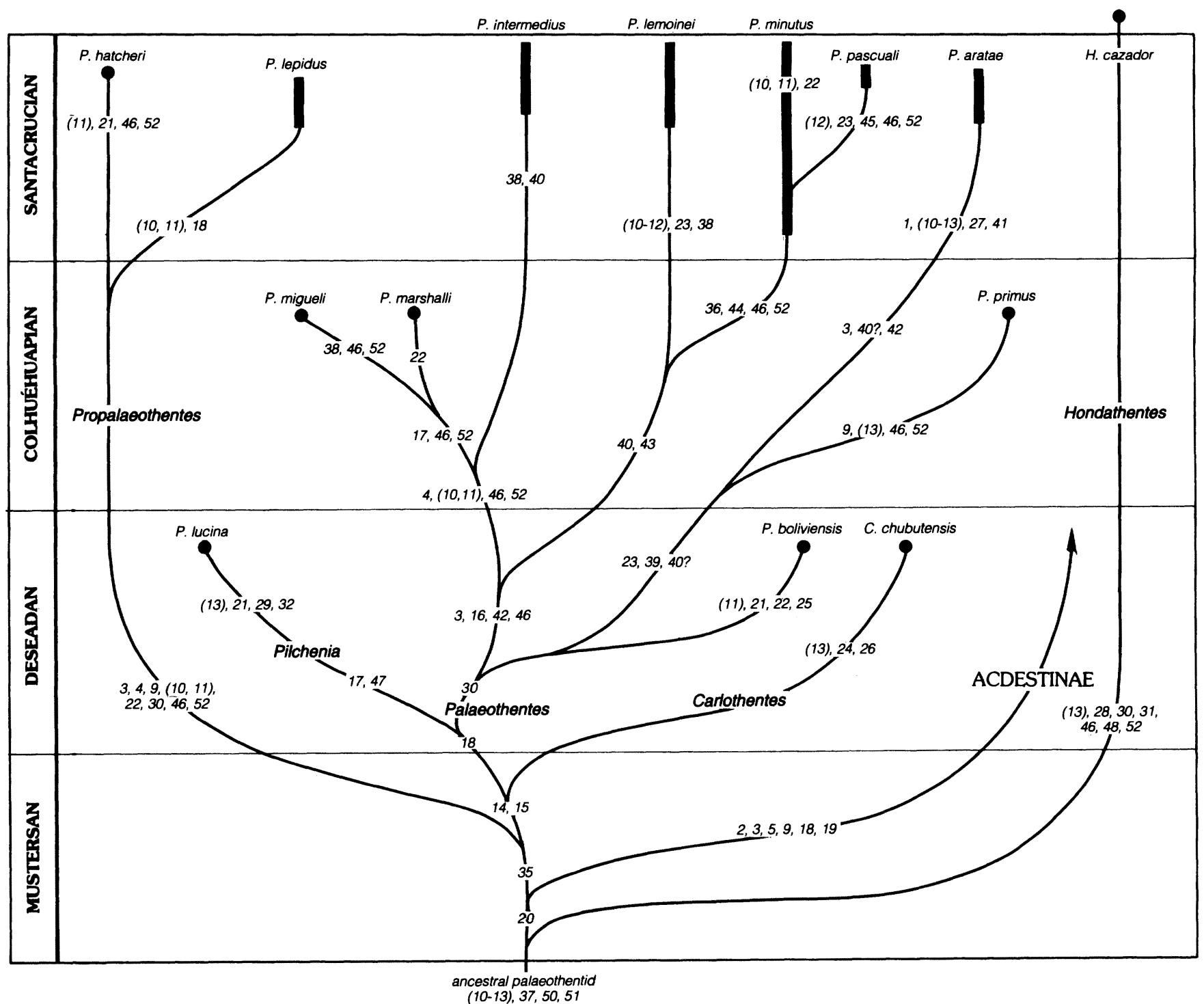

FIGURE 42-Phylogeny of the Palaeothentinae. Numbers refer to derived palaeothentid dental characters in Table 14. First lower molar trigonid structure morphologies in parentheses. Times of differentiation are conjectural but conform with data. Heavy solid lines depict temporal ranges of species.

tiny $P$. pascuali more closely with its diminutive relative $P$. minutus, giving greater weight to their shared small size [46, 52] and narrow [36] and very trenchant [44] molars. Derivation of $P$. pascuali from $P$. minutus is also indicated by time-stratigraphic plots of $\mathrm{m} 1$ and $\mathrm{m} 2$ area in those species (Figures 43, $44)$. Only the type specimen of $P$. pascuali has an $m 1$ area that falls below (and well below) the range of variation seen in $\mathrm{m} 1$ area for $P$. minutus (Figure 43), whereas all $\mathrm{m} 2$ areas in $P$. pascuali lie outside the range of those for $P$. minutus (Figure 44). These data are similar to those typifying the gradual cladogenetic separation of the early Eocene omomyid primates Absarokius abbotti and $A$. metoecus (Bown and Rose, 1987); however, additional stratigraphically controlled samples of the rare Palaeothentes pascuali are necessary before further speculation on the nature and tempo of its origin is warranted.

Like the Acdestinae, the phylogenetic history of the palaeothentines is complex and elucidation of the interrelationships of the several taxa is complicated by numerous instances of convergence, both with relatively distant members of the sub- family and with the acdestines. Convergence is also seen between species in different lineage segments of genus Palaeothentes. The most common examples of convergence (but by no means the only ones) are tooth size and mandibular depth decreases [46, 52]. Some convergences between the Acdestinae and various members of the Palaeothentinae are quite remarkable and are probably evidence of the basic adaptive range of the common heritage of the family Palaeothentidae, plasticity of many characters being retained in a highly variable genotype and becoming manifest at different times, in different groups, and, probably, in different geographic areas and under changing paleoenvironmental conditions.

Good examples of other intersubfamilial convergences are seen in characters $[3,9,10-13,18,22,23,30,39,41]$ (Table $15)$. Others $[4,5,38]$ were perhaps convergent as well, because they document stages in transition between character states that probably existed in antecedents of taxa exemplifying the more derived condition. For example, character [4] is a p3 with a height slightly less than that of the paraconid on the adjacent 


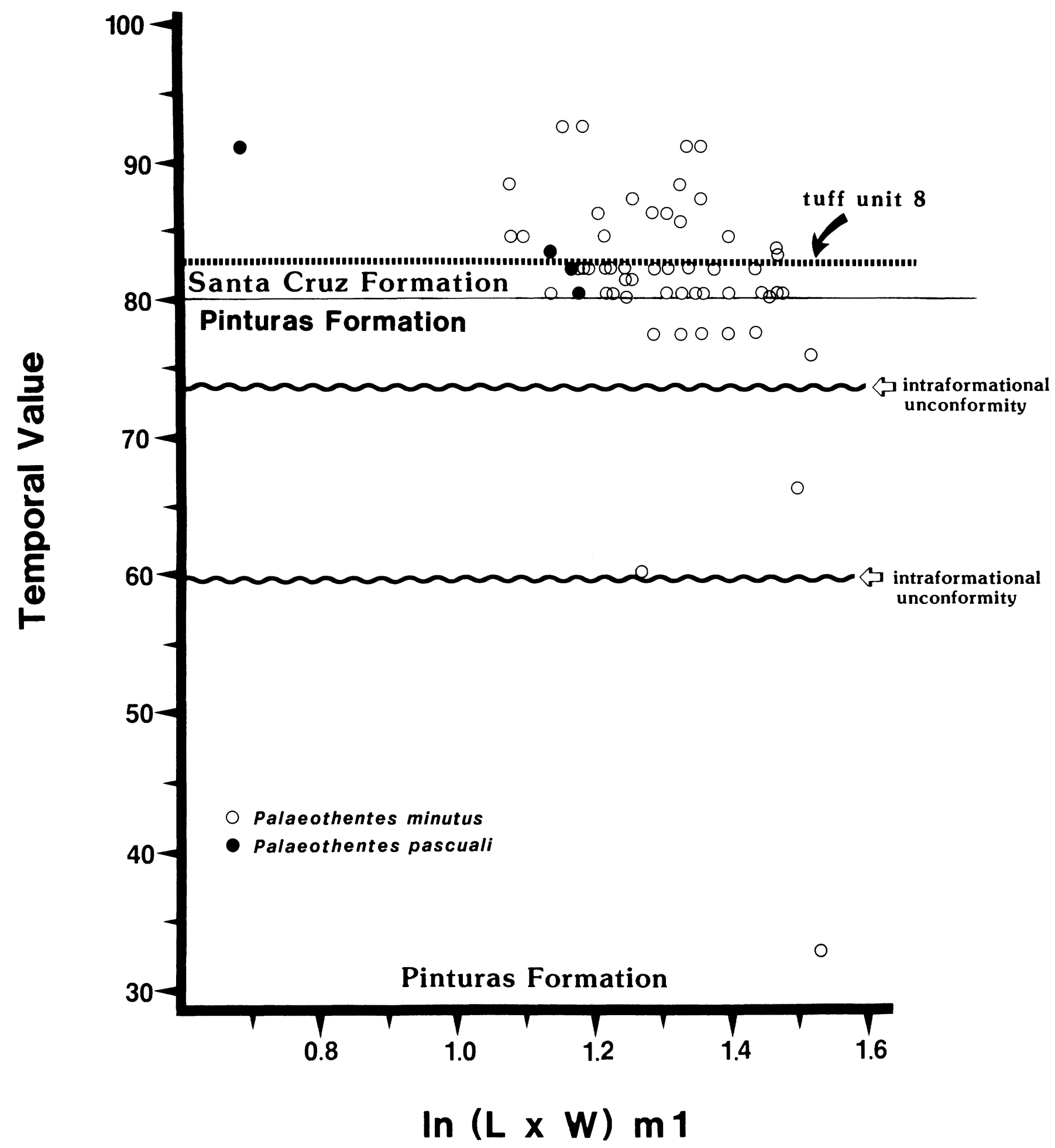

FIGURE 43-Time-stratigraphic distribution of $\mathrm{ml}$ area in Palaeothentes minutus Amegino and P. pascuali $\mathrm{n}$. sp.

$\mathrm{m} 1$, a condition seen in the palaeothentines Propalaeothentes lepidus, Palaeothentes marshalli, $P$. migueli, and $P$. intermedius. All known members of the Acdestinae possess character [5], a p3 that is very small and much shorter than the elevation of the $\mathrm{m} 1$ paraconid. Although it is possible that $\mathrm{p} 3$ reduction in the Acdestinae may have occurred in a single step, evidence of the transition from unreduced $\mathrm{p} 3$ to slightly reduced $\mathrm{p} 3$ exists in the palaeothentine record and can be used as the only empirical measure of how this transformation might have taken place in an as yet unknown member of the Acdestinae.

Similarly, character [38], a moderate stage in the reduction of $\mathrm{m} 3$ area, is present in three species of Palaeothentes and is intermediate between character [37], a large $m 3$, and character [39], very small $\mathrm{m} 3$. Though large $\mathrm{m} 3$ 's typify several palaeo- 


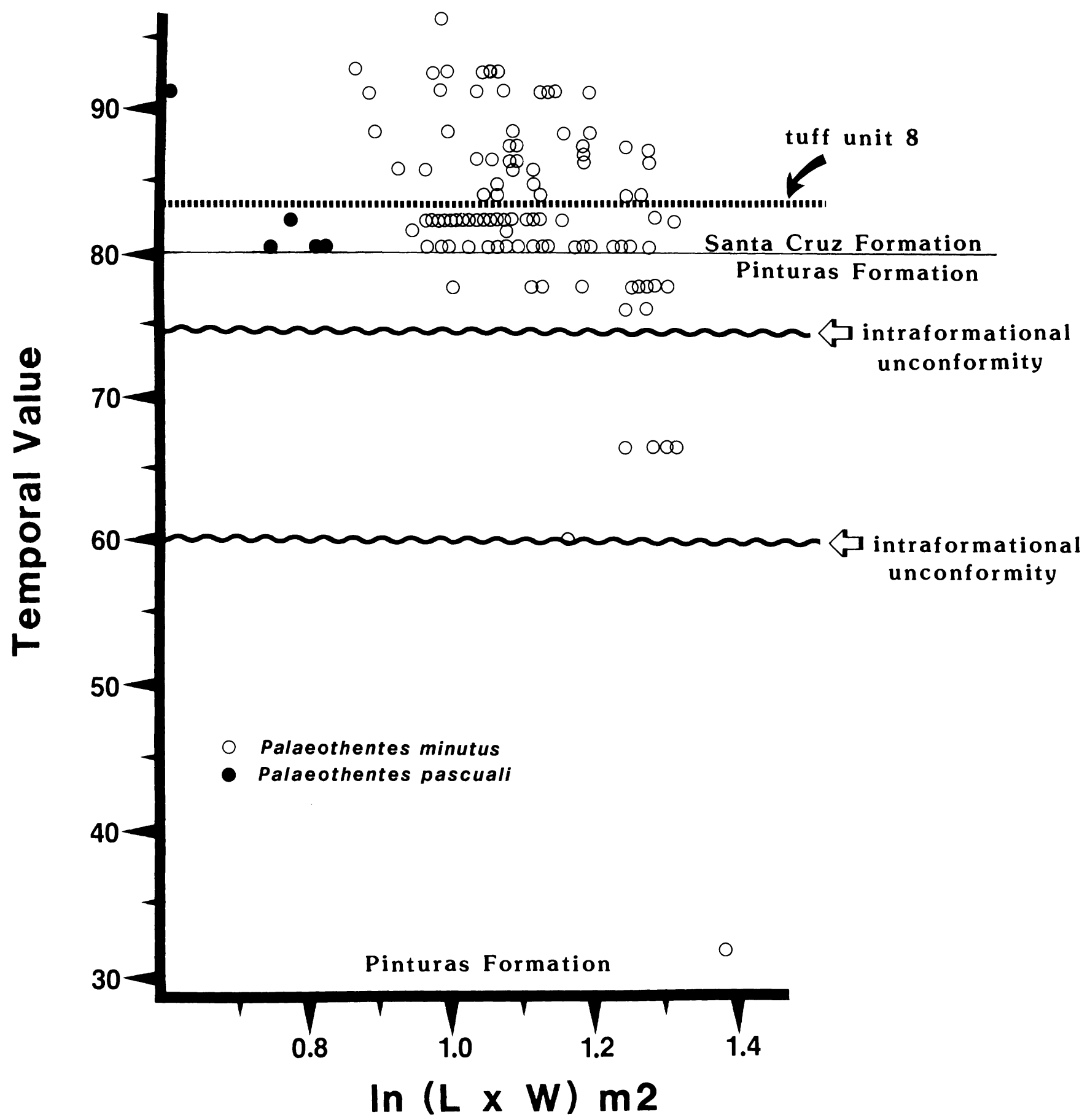

FIGURE 44-Time-stratigraphic distribution of $\mathrm{m} 2$ area in Palaeothentes minutus Ameghino and P. pascuali n. sp.

thentines, they are characteristic only of the acdestine Trelewthentes rothi-all other acdestines possess small $\mathrm{m} 3$ [39]. Both Palaeothentes primus and $P$. aratae have small $\mathrm{m} 3$ like in Acdestinae. Therefore, because the whole transition from large to intermediate to small $\mathrm{m} 3$ is seen clearly in the Palaeothentinae but the intermediate stage [38] is lacking in known acdestines, the requisite evolution most probably transpired like that in the Palaeothentinae and is probably present in an as yet unknown representative of the Acdestinae.

As with the acdestines, all of the earliest (Deseadan) members of the Palaeothentinae were typified by very large teeth; how- ever, the three known Colhuéhuapian species had only small to medium tooth size, and Santacrucian species possessed both the broadest tooth size range as well as the largest and smallest representatives of the subfamily (Figures 28-30). With the exception of Propalaeothentes lepidus (which straddles values for Palaeothentes minutus and $P$. intermedius but has appreciably different dental morphology), there is virtually no overlap of values for molar areas among palaeothentines, although values for Palaeothentes lemoinei and P. intermedius overlap with those of the morphologically disparate acdestines Acdestis oweni and $A$. lemairei (Figures 33, 34). The stratigraphically controlled 
overlap of some $\mathrm{m} 1$ and $\mathrm{m} 2$ areas in Palaeothentes minutus and $P$. pascuali, as observed earlier, almost certainly reflects the gradual cladogenetic differentiation of the two species, a phenomenon also recorded by subtle changes in molar morphology.

The first three lower molars of Palaeothentes minutus gradually decreased in area through time and similar size decrease is seen for $\mathrm{m} 2$ in $P$. lemoinei, $\mathrm{m} 3$ in $P$. pascuali, and possibly also $\mathrm{m} 1$ in $P$. pascuali and Propalaeothentes lepidus, $\mathrm{m} 2$ in Palaeothentes pascuali and $P$. aratae, and $\mathrm{m} 3$ in $P$. lemoinei. There is no appreciable size change through time in $\mathrm{ml}$ of Palaeothentes lemoinei or $P$. aratae, $\mathrm{m} 3$ of $P$. aratae, or any molars of $P$. intermedius.

Size decrease through time was significant for $\mathrm{ml}^{-3}$ in $\mathrm{Pa}$ laeothentes minutus and may also have been for other palaeothentine species for which existing data are suggestive but adequate specimens are lacking. What the size data do show is that no known palaeothentids increased their molar sizes through time and that the earliest representatives of the subfamily, like those of the Acdestinae, had very large molars.

Finally, Figures 33 and 34 suggest that, like in the acdestine Acdestis oweni and the rodent Spaniomys (Lich, 1991; Bown and Anderson, manuscript), there may have been appreciable changes in the size distributions of some molars of some palaeothentine species (e.g., $\mathrm{ml}$ in Palaeothentes minutus and $\mathrm{m} 2$ in $P$. intermedius and $P$. lemoinei) above tuff unit 8 at Monte Observación and Monte León. To the extent that this postulation is correct and is verified by additional specimens, sporadic catastrophic pyroclastic production may have dramatically influenced the course of evolution of most small-bodied middle Tertiary mammals of southern South America.

Origin of Palaeothentidae. - Marshall (1980) believed that the Palaeothentidae (his Palaeothentinae) diverged from a probably unknown caenolestid (his caenolestine) stock at some time between Casamayoran (early Eocene) and Deseadan (later Oligocene) time (during the Mustersan and/or ?Divisaderan), but clearly prior to the Deseadan. Of the but two palaeothentid genera that he considered to be valid, Marshall thought Palaeothentes to be more generalized than Acdestis, noting (1980, p. 127) that "Palaeothentes minutus thus forms a link between the subfamilies Caenolestinae and Palaeothentinae." Marshall based this idea on putative retained generalized characters shared with caenolestins (=Tribe Caenolestini in Marshall's subfamily Caenolestinae), features he believed to be especially explicit in $P$. minutus. These include: "an 'intermediate conule' in unworn M 1-3;" double-rooted p2 in some specimens; $p 3$ equal in height to $\mathrm{ml}$ or taller; and "retention of the 'stamp' of a tuberculosectorial dentition."

In view of the character distributions and dental variability explicit in the Palaeothentidae, we do not believe any of the above criteria to merit especial value in determining polarity of palaeothentid dental attributes or taxa. The "intermediate conule" is mutable in relatively unworn specimens of $P$. minutus, from being well developed to practically absent. A conule also appears in the same locus in some specimens of $P$. intermedius and $P$. aratae, and its only relationship to developments in the Caenolestidae is almost certainly a convergent one. We see no evidence of a double-rooted p2 in Palaeothentes minutus, although the alveolus of one specimen of the acdestine Acdestis oweni appears to have housed a conjoined double-rooted $\mathrm{p} 2$. If present in some $P$. minutus, its variable presence would seem to indicate it is but another of the mutable generalized characters that reappeared from time to time in several palaeothentid lineages. The p3 is equal in height to the $\mathrm{ml}$ paraconid in $P$. minutus, $P$. pascuali, $P$. lemoinei, $P$. boliviensis, $P$. primus, and $P$. aratae (among species of Palaeothentes alone) and does not argue very convincingly that $P$. minutus is any more generalized

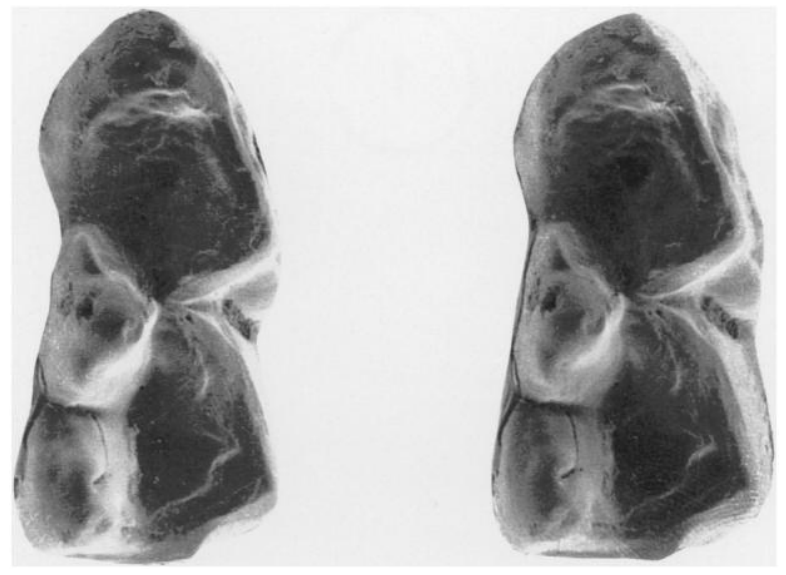

FIGURE 45-SEM photomicrograph of MACN SC-3254, Palaeothentes aratae Ameghino, occlusal aspect of right $\mathrm{ml}, \times 15$. Stereopair.

in this aspect than any of the abovementioned six species. In any case, a tall p3 is generalized for Palaeothentidae as it is for Caenolestidae. Finally, all palaeothentids retain the "stamp" of a tuberculo-sectorial dentition, some more than others and, to our view, $P$. minutus less than many.

Some members of the Palaeothentinae retain primitive characters (a minus character state, or [-]), or they present several different dental morphologies with different proportions of each expression, some of these having to do with quite generalized characters. For example, MACN SC-3254 (Figure 45), a right $\mathrm{ml}$ attributed to Palaeothentes aratae, is the most primitive known palaeothentid tooth in combining 1) pointed but essentially bunodont cusps $[-42], 2$ ) an anteriorly unexpanded entoconid [-27], 3) an untwinned paraconid [-15], 4) a cristid obliqua that meets the postcristid well labial to the metaconid and a protocristid that terminates far labially to the metaconid [ -50 !!; exclamations denote lack of fundamental clade specializations]. MACN SC-3254, therefore, contains a hodge-podge of generalized characters seemingly drawn at random from other very primitive palaeothentids such as Hondathentes, Propalaeothentes, and Palaeothentes primus. The latter species is closest morphologically to $P$. aratae, primitively sharing with it a very weakly expressed $\mathrm{m} 1$ paraconid bifurcation [-16], a tall and unreduced p3 [-4], and (in SC-3254) the very labial juncture of the cristid obliqua with the postcristid [-50!!]. Palaeothentes aratae and $P$. primus also share two quite derived characters: the $\mathrm{ml}$ protocristid is very anterolabially-posterolingually oblique [23], and $\mathrm{m} 3$ is the most reduced [39] seen in palaeothentines.

The Palaeothentinae does seem to include more generalized variants than does the Acdestinae, and new material of palaeothentids described above documents at least six species in four genera that are more generalized as taxa than are any other species of Palaeothentes. These are: 1) Hondathentes cazador [-14, -15, - 18!, -20!, -35]; Propalaeothentes lepidus [-14, -15$,$] ; Propalaeothentes hatcheri [-14,-15,-18$ ! ]; Carlothentes chubutensis [-18!, -30]; Palaeothentes primus [-16, $-50 ! !] ;$ and Palaeothentes aratae [-16, some specimens - 15, some specimens - 50!!). Although the Acdestinae lack a bifurcated (twinned) $\mathrm{ml}$ paraconid $[-15]$ and must have diverged very early from a common palaeothentine-acdestine stock (as the record indeed shows), their uniquely shared host of derived characters $[2,3,5,9,18,19$; all present from the inception of the subfamily -3 and 18 being later, convergent palaeothentine acquisitions] and their near absence of retained primitive character states (even as mutable morphs in individual species) des- 


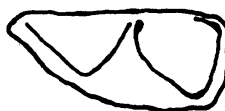

3

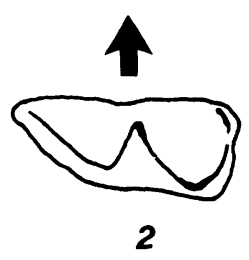

2

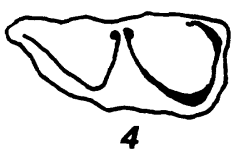

4

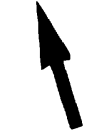

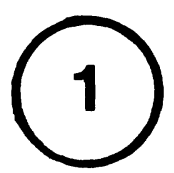
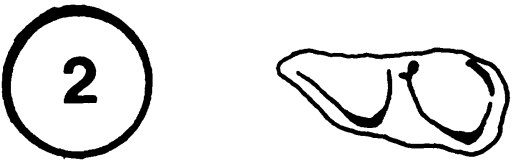

1
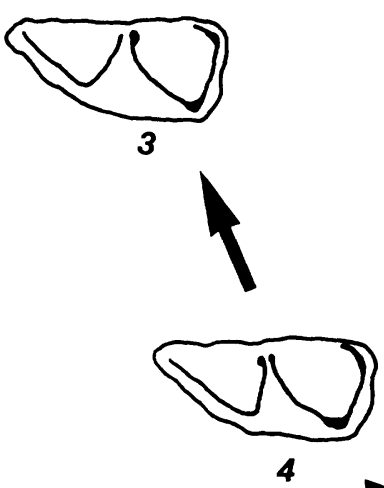

2

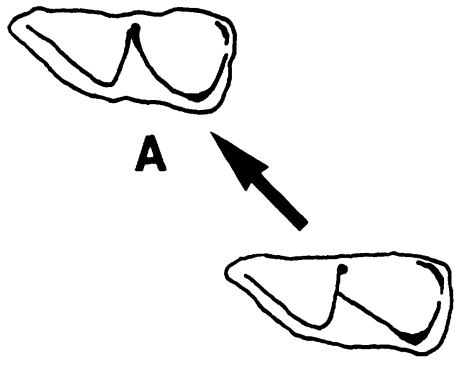

A
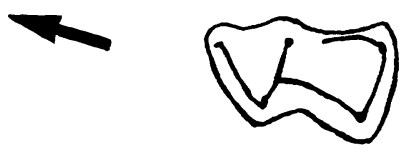
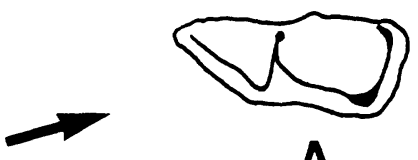

A

FIGURE 46-Hypothetical derivations of $\mathrm{m} 1$ trigonid morphology types $1-4$ in Palaeothentidae. 1 , trigonid types 1 and 2 are plesiomorphic for the Palaeothentidae by both commonality and distribution; whereas, 2, stratigraphic occurrences instead suggest that trigonid types 2 and 4 are primitive for the family. $\mathrm{A}=$ several inferred ancestral morphologies.

ignates them as the more derived, and perhaps the more cohesive, of the two palaeothentid subfamilies. Whereas it is true that the Acdestinae lack certain characters $[-14,-15,-18$, $-30]$, the absence of which was just elevated to significance for the Palaeothentidae, all of them are palaeothentine acquisitions. The absence of each and every one of them guides us well past the separation point of the Palaeothentinae and Acdestinae $[-20$, $-35]$ to the basic derived dental acquisitions of the ancestral palaeothentid [(10-13), 37, 50, 51]- and beyond [-50!!] in $\mathrm{Pa}$ laeothentes primus and at least one specimen of $P$. aratae).

Commonality of the distribution of a character within a clade is commonly utilized as a yardstick of primitiveness, or "plesiomorphy," of that character (especially by cladists), notwithstanding the paradox that it is also commonality of character distributions within clades that comprises the manifesto of procedure in taxonomic ranking. The assumption (and by no means a secure one) is that generalized characters will invariably be more or less rampant and never adequately subsumed by derivations such as to prevent the most abundant characters from also being the more generalized. Few paleontologists believe (or have ever believed) that rank stratigraphic distribution correlates exactly (or even well) with the distribution of generalized versus derived characters, but it is an obvious fact that generalized characters must have appeared earlier in time than their derivatives. Relatively generalized forms can and have survived their forebears, and this phenomenon is the foundation of cladogenesis and the prerequisite of phylogenetic diversity.

The polarity distribution of the four varieties of $\mathrm{ml}$ trigonid structure in the Palaeothentidae (types 1-4 of the text; Figure 11) has proved to be a conundrum in assessing the phylogeny of the family for three reasons. First, the four morphs are distributed more or less evenly throughout the family; second, the different trigonid morphs disappear and reappear with irregular, apparently random frequency; and third, commonality of distribution suggests that type 1 trigonid structure is generalized, whereas stratigraphic distribution marks type 4 as the most primitive of the four morphs.

The Deseadan through Colhuéhuapian acdestine Acdestodon bonapartei (two specimens) has only type 4 [13], and $\mathrm{ml}$ of Deseadan Acdestoides praecursor is unknown. Colhuéhuapian Trelewthentes rothi possesses types 2 and 3 [11, 12], and both species of Santacrucian Acdestis evince types 1-3 [10-12]. Among the palaeothentids, Propalaeothentes possesses types 1 and 2 $[10,11] ;$. lepidus having both morphs and $P$. hatcheri (known from but a single specimen) with only type 2 [11]. Hondathentes cazador, Carlothentes chubutensis, and Pilchenia lucina (each represented by but a single specimen of $\mathrm{ml}$ ) possess only type 4 [13]. Colhuéhuapian and Santacrucian Palaeothentes, on the other hand, exhibit all four trigonid morphologies even though their distribution is restricted. For example, members of the $P$. 
intermedius $-P$. marshalli-P. migueli clade have types 1 and 2 $[10,11]$. The $P$. lemoinei- $P$. minutus $-P$. pascuali clade evinces types 1-3 [10-12], P. lemoinei having all three types [10-12], $P$. minutus types 1 and $2[10,11]$, and $P$. pascuali only type 3 [12]. The Palaeothentes boliviensis $-P$. primus $-P$. aratae clade possesses all four trigonid types [10-13], $P$. aratae retaining them all [10-13], the single specimen taxa $P$. primus having type 4 [13] and $P$. boliviensis type 2 [11]. In terms of percentage of specimens having one type or another, 66 percent of all palaeothentid $\mathrm{ml}$ exhibit type 1 trigonid morphology [10], but only 10 specimens (less than $2.5 \%$ ) have type 4 [13]. This would seem to be a rather clear example of the putatively primitive morph, type $1[10]$, being the dominant expression, were it not for the effectively definitive stratigraphic control on one particular trigonid structure variant. To wit, combined stratigraphic and dental character analyses show that the geologically oldest and/or most generalized palaeothentids are: Hondathentes cazador, Carlothentes chubutensis, Pilchenia lucina, Palaeothentes primus, Palaeothentes aratae, and Palaeothentes boliviensis. Of those taxa, the first four (four known specimens) possess only type 4 . The fifth, Palaeothentes aratae, (a somewhat late occurring species) has three specimens (MACN 14, MACN SC1302 , and MACN SC-3254 = 14\%) with type 4 trigonid morphology. Palaeothentes boliviensis (again a single specimen) has type 2 [11]. Therefore, it is seen that although 66 percent of all palaeothentids possess type $1 \mathrm{ml}$ trigonid morphology, 60 percent of Deseadan (the oldest) forms (represented by only five specimens) evince type 4 [13]. The probability of randomly drawing three specimens in five of a particular trigonid type (4) from a pool of 417 specimens with only 2.5 percent total representation of that type is less than one in 15 trillion. Moreover, type 4 is still the dominant morphology when the oldest palaeothentids are added to the most generalized members of the family, as determined by character analysis. Therefore, we propose type 4 to have been the most likely candidate for primitive $\mathrm{m} 1$ trigonid morphology in Palaeothentidae. The two scenarios that we suppose to have been the most likely for derivation of $\mathrm{m} 1$ trigonid morphology in the Palaeothentidae are depicted in Figure 46. In Figure 46.1, trigonid types 1 and 2 are accorded plesiomorphic for the family on the basis of commonality. In Figure 46.2, trigonid types 2 and 4 are plesiomorphic on the basis of dominance at low stratigraphic positions. Of course, other schemes are possible, if not equally plausible.

The stratigraphic distribution of tooth size in species of $\mathrm{Pa}$ laeothentidae (and tooth size, or areas of molars as used here, is a perfectly valid parameter in discriminating species, as it is in determining character polarities-see, e.g., Gingerich, 1976, and Gingerich and Schoeninger, 1977) indicates that the ancestral palaeothentid had a large $\mathrm{ml}$ (as large as, or larger than $\mathrm{m} 1$ in Carlothentes chubutensis). All of the earliest palaeothentids were possessed of large molars (Figures 28-30). The palaeothentid evolutionary scenario, then, begins with an animal having very large $M 1 / \mathrm{ml}$ with respect to the series $M 2-4 / \mathrm{m} 2-4$, $\mathrm{M} 2-4 / \mathrm{m} 2-4$ decreasing in size posteriorly, in serial sequence, in all palaeothentid clades. But, because the only trends seen in $\mathrm{M} 2-4 / \mathrm{m} 2-4$ size through time are also toward smaller teeth, the ancestral palaeothentid, though certainly having large M1/ $\mathrm{m} 1$, also had large, but perhaps somewhat smaller M2-4/m2$4[-51]$. These data indicate that the Palaeothentidae arose from a stock of marsupials with generalized tribosphenic dentitions having teeth at least as large as those of the largest species of palaeothentid.

In summary, dental character regression analysis indicates that the palaeothentid ancestor had a dentition with quite large teeth [-46] and one that was characterized by the following characters: mandibular ramus relatively deep [-52]; P1 with two roots [ -1$]$; p2 present, unreduced [-2]; p3 large, tall, and broad, basined posteriorly, and with anterobasal cusp [-3 through -9]; M1-3/m l-3 large, more or less equal in size, and with the $\mathrm{m} 3$ area $/ \mathrm{m} 2$ area about $1.0[-37,-38,-39,-51]$; molars with bunodont to piercing, peripherally dispersed cusps, lacking trenchant crests, crenulation, and exodaenodont configuration $[-29,-31,-42,-43,-44,-45,-47,-48,-49]$; $\mathrm{ml}$ cristid obliqua almost certainly confluent with protocristid labial to metaconid $[-50] ; \mathrm{m} 1$ protocristid transversely broad, not very oblique $[-21,-22,-23] ; \mathrm{m} 1$ metaconid associated with trigonid (not talonid) moiety of tooth $[-24,-50]$; $\mathrm{ml}$ with relatively short and transverse paracristid, paraconid and protoconid of approximately equal height, and paraconid and metaconid untwinned [ -10 through -20$]$; $\mathrm{ml}$ talonid as long as trigonid, with straight cristid obliqua, open entoconid notch, and entoconid lacking anterior mure $[-25,-26,-27,-28]$; $\mathrm{m} 2$ with paraconid and strong, more or less transverse protocristid, lacking twinned entoconid $[-30,-32,-33,-34]$; m23 transversely broad, lacking vespiform constriction between entoconid notch and hypoflexid [ $-35,-36]$; M1 hypocone platform unexpanded lingually [ -40$]$. M4/m4 probably reduced but not greatly so and with distinct cusps [-41].

The only suitable ancestral marsupial for this hypothetical form is an unknown didelphid. Known members of the Caenolestidae (Caenolestinae and Pichipilinae, promoted by Marshall, 1980 , as ancestral to the Palaeothentidae), though possessing tribospenic molars, are unsatisfactory for a number of reasons. All known fossil and extant caenolestids have exceedingly small body size-most are considerably smaller than Palaeothentes pascuali, the most diminutive palaeothentid. All pichipilines may be excluded because of molar specializations, including short, compressed, and anteriorly canted trigonids, long talonids (much longer than the trigonids), and sharp, crestiform cusps. The caenolestines are also excused due to myriad cheek tooth specializations. Chief among these are an elongate and trenchant p3; tall, sharp, and piercing molar cusps in conjunction with a trenchant, crestiform $\mathrm{ml}$ paracristid; trenchant entoconids, commonly with a sharp anterior mure; an already greatly reduced M4/4 (it is difficult to imagine m4 of Pilchenia lucina arising from that tooth in any known caenolestine); already fully quadrate upper molars with well developed hypocone platforms on M1 and M2; a huge M3 metaconule (in the fossil caenolestine Stilotherium dissimile); and confluent trigon and talon basins.

The phylogenetic relationships of the Palaeothentidae to other groups of Cenozoic marsupials of South America is problematical and must await additional material of the earliest known (and yet earlier, presently unknown) palaeothentids. The record of the Tertiary Didelphidae is lamentably poor, notwithstanding the magnificent record from the Paleocene of Itaborái, Brazil (Paula Couto, 1952a). We agree with Marshall (1980, p. 129) that Ríochican Derorhynchus singularis offers some tantalizing similarities to early palaeothentid specializations; however, as noted by Paula Couto (and in view of the overwhelming evidence of convergence in the middle Tertiary Palaeothentidae), the early specializations of that species may well not signify a real relationship. The Abdertidae share a number of superficial features with palaeothentids but most of these, though suggestive, have been accomplished differently (e.g., the development of a bladelike, shearing $\mathrm{m} 1$ by elongation of the paracristid and subsuming importance of the trigonid cusps). In any case, the abderitids share misleading, convergent gross dental similarities with other groups (Polydolopidae) whose affinities to them are surely exceedingly remote (Paula Couto, 1952b). The Abderitidae are also now deserving of extensive revision, especially in view of the more than 1,200 new specimens collected in the past few years by the joint SUNY/MACN expeditions. 


\section{SUMMARY AND CONCLUSIONS}

The Palaeothentidae is an extinct family of caenolestoid marsupials that arose in the late early Tertiary (Mustersan or earlier) from an unknown marsupial stock, probably a didelphid. The earliest records of the family are from the later Oligocene (Deseadan) of Bolivia and southern Patagonia, Argentina. Santacrucian (and perhaps later) records are known from Argentina, Chile, and Colombia. The most generalized palaeothentid, Colombian Hondathentes cazador, is also geologically the youngest and geographically the most extraneous from the largest and best known samples. It is very likely that palaeothentids had a distribution that embraced most of South America, probably since Deseadan time.

The evolution of the family is complicated and was typified by manifest convergence of dental characters throughout its history and by the persistence of dental character plasticity. This last included the retention, for a considerable period of geologic time, of a host of minor dental morphologic variants whose percent distribution varied among certain palaeothentine clades but for which no one morph ever achieved complete dominance. Certain of these morphs appear to have been phenotypically "lost" for extended periods of time, and then reappeared as one of several variants. Certain of them betoken exceedingly generalized earlier morphologies, some from a pre-palaeothentid grade of evolution. In cases in which this pattern of local anagenesis pertains to molar size in Palaeothentidae, extinction of the local population and replacement by a more conservative population is consistent with Futuyma's (1992) model of apparent paleontological stasis despite considerable genetic adaptation among local populations. It seems very likely that the retention of a high variety of both generalized and advanced morphs for the same phenotypic manifestation was in some way related to the peculiar geologic conditions under which the palaeothentids (at least those of Patagonian distribution) played out their history. Theirs was an environment characterized by numerous episodes of pyroclastic aeolian deposition, several events of which truly may be termed catastrophic, and some of which appear to have resulted in the extermination of (at the very least) regional populations of small mammals. Although recovery and repopulation of devastated areas appear to have been very rapid on a geological scale, replacement populations differed in their phenotypic representation of particular dental attributes from that of the defunct populations. It is suggested that the new, recolonizing forms were drawn from populations possessing a somewhat different genotype, one that emphasized, to a greater or lesser degree, morphs typical of the species populations as a whole. In sum, evolution in the Palaeothentidae appears to have been accomplished gradually, but was punctuated by stochastic, non-Darwinian reordering of the percent distribution of dental characters imposed by geologic processes.

As a speculative venture, it is also inferred that the gross late early-middle Tertiary stratigraphic record of the Palaeothentidae suggests replacement of quite derived forms by somewhat more generalized species, and that the newcomers then went on to achieve specializations of their own, most quite different from those accomplished by their forebears. Nonetheless, certain adaptive types seem to have enjoyed success, even if their hallmark morphologies were developed in extraneous lineages. Using the Palaeothentinae as an example, the Deseadan taxa Pilchenia lucina, Palaeothentes boliviensis, and Carlothentes chubutensis, though all possessed of several generalized features to be sure, were replaced by the in many ways even more primitive Colhuéhuapian forms Palaeothentes migueli, $P$. marshalli, and $P$. primus. Pilchenia lucina was a very derived form, possessing the deepest $\mathrm{m} 1$ paraconid bifurcation of any palaeothen- tine, trenchant and twinned $\mathrm{m} 2$ entoconids, a transversely narrow $\mathrm{ml}$ protocristid, and crenulated enamel on m1-3. Palaeothentes boliviensis also had a transversely narrow $\mathrm{m} 1$ protocristid, it had a somewhat anterolabially-posterolingually oblique $\mathrm{ml}$ protocristid, and the $\mathrm{ml}$ talonid was very short. Carlothentes chubutensis had a very posteriorly situated $\mathrm{ml}$ metaconid and an $\mathrm{m} 1$ cristid obliqua that was bent at its midline. Among Colhuéhuapian replacement taxa, Palaeothentes marshalli and $P$. migueli also had very deep bifurcation of the $\mathrm{m} 1$ paraconid, but not so deep as in Pilchenia. Both lacked the exotic specializations of $P$. lucina, concentrating their differences from that form on decreased mandibular and molar size, shortening of $\mathrm{p} 3$, and loss of the $\mathrm{m} 2$ paraconid. Colhuéhuapian Palaeothentes primus is among the most generalized of all palaeothentids, possessing an $\mathrm{ml}$ cristid obliqua that terminates on the protocristid well labial to the metaconid, a condition far more generalized than that in Deseadan $P$. boliviensis or Carlothentes chubutensis. The frugal specializations of Palaeothentes primus include loss of the anterobasal cusp on $\mathrm{p} 3$, decrease in $\mathrm{m} 3$ size, and general decrease in mandibular depth and molar areas.

Similar reappearances of more generalized palaeothentid dental morphologies occur with the inception of the Santacrucian fauna, and throughout the history of the Acdestinae (for example, compare the detailed specializations of Colhuéhuapian Trelewthentes rothi with those of Santacrucian Acdestis oweni, or even $\mathrm{m} 2$ in Deseadan Acdestoides praecursor with that tooth in either Acdestodon bonapartei or Acdestis oweni). Hondathentes cazador, the geologically youngest palaeothentid, is the most primitive of all members of the family. The second and third most primitive, the two species of Propalaeothentes, and $\mathrm{Pa}$ laeothentes aratae enjoyed a distribution embracing most of the Santacrucian.

It seems likely that the more generalized of the available species (as with having a number of available mutable dental character morphs, as outlined above) conferred an adaptive advantage on recolonizing populations. A similar phenomenon, the general replacement of what are, in many ways, more derived species by more generalized species, has been observed for early Eocene biohorizon boundary mammalian faunas in Wyoming (Bown et al., 1992).

Finally, dental character regression is a formidable tool in analyzing both the character polarities and in discriminating potential ancestries of phyla, especially so in embrangled groups like the Palaeothentidae in which retained generalized variability is common. Stratigraphic study of the percent distributions of the various morphs of mutable characters is critical to understanding both the nature and tempo of evolutionary change in fossil organisms.

\section{ACKNOWLEDGMENTS}

We are grateful to J. G. Honey and C. A. Repenning for reviews of earlier drafts of this manuscript, and to K. D. Rose, D. Anderson, K. Reed, and G. Rougier for discussion. J. F. Bonaparte generously permitted us to study materials in the collections of the MACN, and we made use of comparative fossils and casts housed in the care of M. Coombs (ACM), J. H. Hutchison (University of California, Berkeley, CA), L. Krishtalka (Carnegie Museum of National History, Pittsburgh, PA), M. C. McKenna (AMNH), R. F. Kay (Department of Biological Anatomy and Anthropology, Duke University), and J. H. Ostrom and M. A. Turner (YPM-PU specimens at the Yale Peabody Museum, New Haven, CT). Figures 10, 12-14, 16-23 were skilfully executed by Elaine Kasmer, and we are grateful to Marj Leggitt and Luci Betti who crafted the frontispieces.

In the field, we were ably assisted by Dra. A. Albino, G. Buckley, L. Chiappe, Dr. R. Ciochon, Dr. G. Conroy, S. Cor- 
nero, M. Cozzuol, O. Donadio, V. Dressino, C. Dubois, E. Dumont, Dr. V. Escribano, Dr. J. Genise, P. Hazeldine, I. Horovitz, C. Larriestra, Dr. J. Meldrum, Dr. D. Powers, Dr. A. Rosenberger, G. Rougier, E. Ruiz-Gomez, E. Sarmiento, E. Schloeder, M. Soria, C. Swisher, M. Tejedor, R. Vacca, C. Wall, and A. Walton. We especially thank Henri and Helen Lemaire of Estancia Cañadon de las Vacas (Pva. Santa Cruz) for graciously allowing access to localities on their land at Monte Observación, and for their provident hospitality.

Nearly all of this research was funded by National Geographic Society grant $2440-82$ and National Science Foundation grants BNS-82-10949, BNS-86-06796, and BNS-90-12154 to J. G. Fleagle. T. M. Bown acknowledges National Geographic Society grant 3985-89 in support of paleosol studies.

\section{REFERENCES}

Ameghino, F. 1887. Enumeración sistemática de las especies de mamíferos fósiles coleccionados por Cárlos Ameghino en los terranos eocenos de la Patagonia austral y depositados en el Museo La Plata. Boletin Museo de La Plata, 1:1-26.

- 1889. Contribución al conocimiento de los mamíferos fósiles de la República Argentina, obra escrita bajo los auspicios de la Academia Nacional de Ciencias de la República Argentina para preentarla a la Exposicion Universal de Paris de 1889. Actas Academia de las Ciencias de Córdoba, 6:1-1027.

—. 1890. Los plagiaulacidos argentinos y sus relaciones zoológicas, geológicas, y geográficas. Boletin Instituto geográfia argentino, 11: 143-201.

- 1891. Nuevos restos de mamíferos fósiles descubiertos por Cárlos Ameghino en el Eoceno inferior de la Patagonia austral. Especies nuevas, adiciones y correciones. Revista Argentina de Historia Natural, 1:289-328.

- 1893. Les premiers mammiferes. Rélations entre les mammifêres diprotodontes éocénes de l'Amerique de Nord et ceux de la Repúblique Argentine. Revue génerale Sciences (Paris), 4:77-81.

- 1894. Enumération synoptique des espécies de mammiferes fossiles des formations éocénes de Patagonie. Boletin de Academia de Ciencias Córdoba, 13:259-452.

- 1897. Mammifères ćretacés de l'Argentine. (Deuxième contribution a la connaissance de la faune mammalogique des couches à Pyrotherium.) Boletin Instituto geográfia argentino, 18:406-521.

- 1898. Sinopsis geológica-paleontológica. Segundo censo de la República Argentina. Fol., Buenos Aires, 1:112-255.

. 1901. L'age des formations sédimentaires de Patagonie. Anales de Sociedad de Ciencias argentinas, 52:189-197, 244-250.

- 1902. L'age des formations sédimentaires de Patagonie. Anales de Sociedad de Ciencias argentinas, 54:161-180, 220-249, 283-342.

_. 1903. Los diprotodontes del orden de los plagiaulacoideos y el origen de los roedores y de los polimastodontes. Anales de Museo Nacional de Buenos Aires, Series 3, 1:81-192.

- 1906. Les formations sédimentaires du cretáce superieur et du tertaire de Patagonie avec un parallèle entre leurs faunes mammalogiques et celles de l'ancien continents. Anales de Museo Nacional de Buenos Aires, Series 3, 8:1-568.

Barrio, R. E. De, G. Scillato-Yane, AND M. Bond. 1984. La formacion Santa Cruz en el borde occidental del macizo del Deseado (Provincia de Santa Cruz) y su contenido paleontológico. Actas Nov. Congreso Geológico Argentino (S. C. de Bariloche, 1984), IV:539556.

Bown, T. M., AND D. K. ANDERSON. Manuscript. Rapid local extinction and replacement in Miocene marsupials and rodents: examples of bottleneck and founder effects? Journal of Vertebrate Paleontology.

- , E. R. Dumont, J. G. Fleagle, and O. A. Reig. 1990. Abderitine and palaeothentine caenolestid marsupials from Santacrucian deposits in southern Argentina. Journal of Vertebrate Paleontology, 10(supplement to no. 3):14A-15A.

- AND M. J. KRAUS. 1981. Vertebrate fossil-bearing paleosol units (Willwood Formation, lower Eocene, northwest Wyoming, U.S.A.): implications for taphonomy, biostratigraphy, and assemblage analysis. Palaeogeography, Palaeoclimatology, Palaeoecology, 34:31-56.
—, AND - 1987. Integration of channel and floodplain suites: I. Developmental sequence and lateral relations of alluvial paleosols. Journal of Sedimentary Petrology, 57:587-601.

$\longrightarrow$ AND - In press. Time-stratigraphic reconstruction and integration of paleopedologic, sedimentologic, and biotic events (Willwood Formation, lower Eocene, northwest Wyoming, U.S.A.). Palaios.

,-- , AND K. D. Rose. 1991. Temporal holostrome reconstruction of the Willwood Formation and the reapportionment of paleopedologic, sedimentologic, and paleobiotic events in time. Journal of Vertebrate Paleontology, 11(supplement to no. 3):17A.

- AND C. N. LARRIESTRA. 1990. Sedimentary paleoenvironments of fossil platyrrhine localities, Miocene Pinturas Formation, Santa Cruz Province, Argentina. Journal of Human Evolution, 19:87-119.

,-- AND D. W. Powers. 1988a. Analisis paleoambiental de la formación Pinturas (Mioceno inferior), Provincia de Santa Cruz. Segunda Reunion Argentina de Sedimentológia, Actas, 1:31-35.

,,--- C. W. NAeser, AND K. TABbutT. 1988b. New information on age, correlation, and paleoenvironments of fossil platyrrhine sites in Argentina. Journal of Vertebrate Paleontology, 8:9A. - AND J. H. LAZA. 1990. A Miocene fossil termite nest from southern Argentina and its paleoclimatic implications. Ichnos, 1:73-79.

-, AND D. W. PowERS. Manuscript. Sedimentary paleoenvironments and geologic history of the Sarmiento Formation (Eocene-Oligocene), eastern Río Chubut valley and Pampa de Gan Gan, Chubut Province, Argentina.

- AND K. D. Rose. 1987. Patterns of dental evolution in Early Eocene anaptomorphine primates (Omomyidae), from the Bighorn Basin, Wyoming. Paleontological Society Memoir 23, 162 p.

,-- AND M. J. Kraus. 1992. Relation of extinctions and immigrations of Omomyidae and other mammals to paleosol type, sediment accumulation rates, and tectonics. American Journal of Physical Anthropology, 87(supplement to no. 4):52.

СамаCHO, H. H. 1974. Bioestratigráfia de las formaciónes marinas del Eoceno y Oligoceno de la Patagonia. Anales Academia Ciencias Ex. Fisicas Naturales, 26:39-57.

Castellanos, A. 1937. Ameghino y la antiguedad del hombre sudaméricano. Conferencia de Asociación Cultural (Rosario), 2:47-192.

ChIAPPE, L. M. 1991. Fossil birds from the Miocene Pinturas Formation of southern Argentina. Journal of Vertebrate Paleontology, 11(supplement to no. 3):21A-22A.

Clemens, W. A., and L. G. Marshall. 1976. Fossilium Catalogus: American and European Marsupialia. W. Junk, The Hague (Pars 123), p. $1-114$

Dumont, E. R., AND T. M. Bown. In press. New caenolestoid marsupials from the La Venta Formation (Miocene) of Colombia. In R. F. Kay, R. L. Cifelli, R. H. Madden, and J. J. Flynn (eds.), The History of the Neotropical Fauna: Vertebrate Paleobiology of the Miocene of Tropical South America. Springer-Verlag, New York.

Feruglio, E. 1938. Nomenclatura estratigráfica de la Patagonia y Tierra del Fuego. Bóletin Informacion Petróleo, Y.P.F., 171.

Fleagle, J. G. 1990. New fossil platyrrhines from the Pinturas Formation, southern Argentina. Journal of Human Evolution, 19:61-85. - AND T. M. Bown. 1983. New primate fossils from late Oligocene (Colhuéhuapian) localities of Chubut Province, Argentina. Folia primatologica, 41:240-266.

-, AND R. F. KAY. 1989. The dental morphology of Dolichocebus gaimanensis, a fossil monkey from Argentina. American Journal of Physical Anthropology, 78:221.

- D. W. Powers, G. C. Conroy, and J. P. Watters. 1987. New fossil platyrrhines from Santa Cruz Province, Argentina. Folia primatologica, 48:65-77.

FRENGUELLI, J. 1931. Nomenclatura estratigráfica patagonica. Anales Sociedad Ciencias Santa Fe, 3:1-115.

FutUYMA, D. J. 1992. History and evolutionary process, p. 103-130. In M. H. Nitecki and D. V. Nitecki (eds.), History and Evolution. State University of New York Press, Albany.

GENISE, J. F., AND T. M. Bown. In press. Paleoichnology and paleoenvironmental reconstruction of Santacrucian (Miocene) fossil vertebrate localities, Santa Cruz Province, Argentina. Ichnos.

GINGERICH, P. D. 1976. Paleontology and phylogeny: patterns of evolution at the species level in early Tertiary mammals. American Journal of Science, 276:1-28. 
- AND M. SCHOENINGER. 1977. The fossil record and primate phylogeny. Journal of Human Evolution, 6:483-505.

HATCHER, J. B. 1903. Narrative of the expeditions and geography of southern Patagonia. Report of Princeton University Expeditions to Patagonia, Princeton, 1:1-314.

HeRshkovitz, P. 1974. A new genus of late Oligocene monkey (Cebidae, Platyrrhini) with notes on postorbital closure and platyrrhine evolution. Folia Primatologica, 21:1-35.

HonaCKI, J. H., K. E. KinMan, AND J. W. Koeppl (eds.). 1982. Mammal Species of the World; a Taxonomic and Geographic Reference. Allen Press, Lawrence, Kansas, 694 p.

ILligeR, C. 1811. Prodromus systematis mammalium et avium additis terminis zoographicis utrudque classis. C. Salfeld, Berlin, $301 \mathrm{p}$.

KIRSCH, J. A. W. 1968. Prodromus of the comparative serology of Marsupialia. Nature, 217:418-420.

- 1977. The comparative serology of Marsupialia. Australian Journal of Zoology, 52:1-152.

- AND J. H. CalABY. 1977. The species of living marsupials; an annotated list, p. 9-26. In B. Stonehouse and D. Gilmore (eds.), The Biology of Marsupials. Macmillan Press, Baltimore.

Kraglievich, J. L. 1953. Contribuciones al conocimiento de los primates fósiles de la Patagonia. Anales Museo de Nahuel Huapí, 3:3762.

KRAUS, M. J. 1987. Integration of channel and floodplain suites: II. Vertical relations of alluvial paleosols. Journal of Sedimentary Petrology, 57:602-612.

-, AND T. M. BowN. 1986. Palaeosols and time resolution in alluvial stratigraphy, p. 180-207. In P. V. Wright (ed.), Palaeosols: Their Recognition and Interpretation. Blackwell, London, $315 \mathrm{p}$.

Lich, D. K. 1991. Fossil rodents from the Pinturas Formation and the Santa Cruz Formation, early Miocene, southern Argentina. Journal of Vertebrate Paleontology, 11(supplement to no. 3):43A.

LoOMIS, F. B. 1914. The Deseadan Formation of Patagonia. Concord Press, New Haven, 232 p.

$\rightarrow$ Marshall, L. G. 1976. Fossil localities for Santacrucian (early Miocene) mammals, Santa Cruz Province, southern Patagonia, Argentina. Journal of Paleontology, 50:1129-1142.

- 1980. Systematics of the South American marsupial family Caenolestidae. Fieldiana (Geology), n.s., 5:1-145.

- 1981. The families and genera of Marsupialia. Fieldiana (Geology), 8:1-65.

-1 1990. Fossil Marsupialia from the type Friasian land mammal age (Miocene), Alto Río Cisnes, Aisen, Chile. Revista Geológica de Chile, 17:19-55.

-, R. R. Drake, G. H. Curtis, R. F. Butler, K. M. Flanagan, AND C. W. NAESER. 1986. Geochronology of type Santacrucian (middle Tertiary) land mammal age, Patagonia, Argentina. Journal of Geology, 94:449-457.

- R. Hoffstetter, AND R. Pascual. 1983. Mammals and stratigraphy: geochronology of the continental mammal-bearing Tertiary of South America. Palaeovertebrata, Memoire Extraordinaire (1983): $1-93$.

- AND R. PASCUAL. 1977. Nuevos marsupiales Caenolestidae del "Piso Notohipidense" (SW de Santa Cruz, Patagonia) de Ameghino. Sus aportaciones a la cronológia y evolución de las comunidades de mamiféros sudamericanos. Publicacion del Museo Municipal de las Ciencias Naturales Mar del Plata "Lorenzo Scaglia," 2:91-122.

$\longrightarrow$, AND - 1978. Una escala temporal radiometrica preliminar de las edades-mamífero del Cenozoico medio y tardio sudamericano. Obra Centinario del Museo de La Plata, 5:11-28.

$\rightarrow-,-$ G. H. Curtis, AND R. E. Drake. 1977. South American geochronology: radiometric time-scale for middle to late Tertiary mammal-bearing horizons in Patagonia. Science, 195:1325-1328.

MendiA, J. E., AND A. BAYARSKY. 1981. Estratigráfia del Terciaro en el valle inferior del Río Chubut. VIII Congreso Geológia Argentino (San Luis), Actas, III:593-606.

MORENO, F. P. 1882. Patagonia. Resto de un antiguo continente hoy sumergido. Anales de Sociedad de las Ciencias Argentina, 14:97-131.
OsGood, W. H. 1921. A monographic study of the American marsupial Caenolestes. Field Museum of Natural History Zoological Series, 14:1-162.

Pascual, R., and O. E. Odreman Rivas. 1971. Evolucion de las comunidades de los vertebrados del Terciario Argentino. Los aspectos paleozoogeográficos y paleoclimaticos relacionados. Ameghiniana, $8: 372-412$.

- E. Ortega Hinojosa, D. Gondar, AND E. TonNI. 1965. Las edads del Cenozoico mamaliféro de la Argentina, con especial atencion a aquellas del territorio bonaerense. Anales Comision Investigaciónes Ciencias (Buenos Aires), 6:165-193.

-, M. G. Vucetich, G. J. Scillato-Yane, AND M. Bond. 1985. Main pathways of mammalian diversification in South America, $p$. 219-247. In F. G. Stehli and S. D. Webb (eds.), The Great American Biotic Interchange. Plenum, New York.

Patterson, B., AND L. G. Marshall. 1978. The Deseadan, early Oligocene, Marsupialia of South America. Fieldiana (Geology), 41: 37-100.

Paula Couto, C. DE. 1952a. Fossil mammals from the beginning of the Cenozoic in Brazil. Marsupialia: Didelphidae. American Museum Novitates, 1567:1-26.

- 1952b. Fossil mammals from the beginning of the Cenozoic in Brazil. Marsupialia: Polydolopidae and Borhyaenidae. American Museum Novitates, 1559:1-27.

RAmos, V. A. 1982. Geológia de la region del Lago Cardiel, Provincia de Santa Cruz. Asociación Geológia Argentina Revista, 37:23-49.

RIDE, W. D. L. 1964. A review of Australian fossil marsupials. Journal Royal Society of Western Australia, 47:97-131.

Rusconi, C. 1935. Nuevos restos de monos del tertario antiguo de la Patagonia. Anales Sociedad Cientifico Argentino, CXVI:286-289.

Russo, A., AND M. A. Flores. 1972. Patagonia Austral Extra Andina, p. 707-725. In A. F. Leanza (ed.), Geológia Regional Argentina. Academia Nacional Ciencias de Córdoba.

Savage, D. E., AND D. E. Russell. 1983. Mammalian Paleofaunas of the World. Addison-Wesley, London.

SimPSON, G. G. 1935. Early and middle Tertiary geology of the Gaiman region, Chubut, Argentina. American Museum Novitates, 775:1-29. - 1945. The principles of classification and a classification of mammals. American Museum of Natural History Bulletin, 85:1-350.

. 1948. The beginning of the age of mammals in South America. Part I. American Museum of Natural History Bulletin, 91:1-232.

- 1970. The Argyrolagidae, extinct South American Marsupials. Museum of Comparative Zoology Bulletin, 139:1-86.

- 1971. The evolution of marsupials in South America. Anales Academia do Brasil Ciencias, 43:1-118.

SinCLAIR, W. J. 1906. Mammalia of the Santa Cruz beds; Marsupialia. Report of the Princeton University Expedition to Patagonia, 4:333460.

Strait, S. G., J. G. Fleagle, T. M. Bown, AND E. R. Dumont. 1990. Diversity in body size and dietary habits of fossil caenolestid marsupials from the Miocene of Argentina. Journal of Vertebrate Paleontology, 10(supplement to no. 3):44A.

Trouessart, E. L. 1905. Catalogus Mammalium tam viventium quam fossilium. Quinquinale supplementum (2 vols.). Berlin, 547-929.

WALKeR, A. C. 1978. Prosimian primates, p. 90-99. In V. J. Maglio and H. B. S. Cooke (eds.), Evolution of African Mammals. Harvard University Press, Cambridge.

Walker, E. P., F. Warnick, S. E. Hamlet, K. I. Lange, M. A. Davis, H. E. Uible, AND P. F. Wright. 1975. Mammals of the World, 3rd ed., Volume 1. Johns Hopkins University Press, Baltimore, 644 p.

WINGE, H. 1923. Pattedyr-Slaegter. I. Monotremata, Marsupialia, Insectivora, Chiroptera, Edentata. Copenhagen, 360 p.

Wood, A. E., AND B. Patterson. 1959. Rodents of the Deseadan Oligocene of Patagonia and the beginnings of South American rodent evolution. Museum of Comparative Zoology Bulletin, 120:281-428.

ACCEPTED 13 JULY 1992 